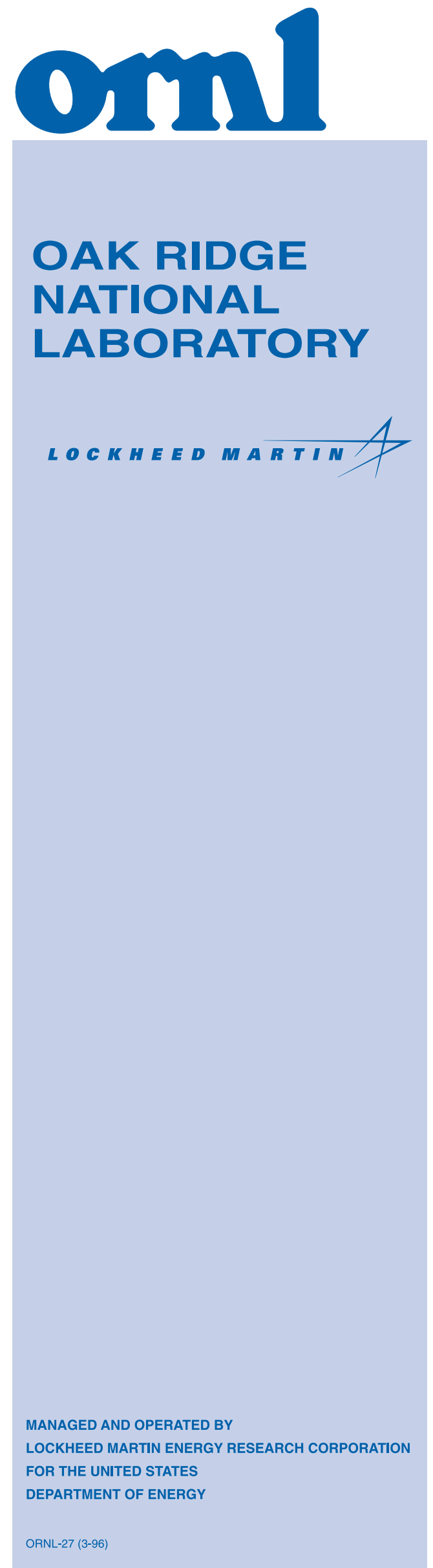

\title{
Validation of SCALE (SAS2H) Isotopic Predictions for BWR Spent Fuel
}

O. W. Hermann

M. D. DeHart 
This report has been reproduced directly from the best available copy.

Available to DOE and DOE contractors form the Office of Scientific and Technical Information, P.O. Box 62, Oak Ridge, TN 37831; prices available from (615) 576-8401.

Available to the public from the National Technical Information Service, U.S. Department of Commerce, 5285 Port Royal Rd., Springfield, VA 22161.

This report was prepared as an account of work sponsored by an agency of the United States Government. Neither the United States nor any agency thereof, nor any of their employees, makes any warranty, express or implied, or assumes any legal liability or responsibility for the accuracy, completeness, or usefulness of any information, apparatus, product, or process disclosed, or represents that its use would not infringe privately owned rights. Reference herein to any specific commercial product, process, or service by trade name, trademark, manufacturer, or otherwise, does not necessarily constitute or imply its endorsement, recommendation, or favoring by the United States Government or any agency thereof. The views and opinions of authors expressed herein do not necessarily state or reflect those of the United States Government or any agency thereof. 
ORNL/TM-13315

Computational Physics and Engineering Division

\section{VALIDATION OF SCALE (SAS2H) ISOTOPIC PREDICTIONS FOR BWR SPENT FUEL}

O. W. Hermann and M. D. DeHart

Date Published: September 1998

Prepared by the

OAK RIDGE NATIONAL LABORATORY

managed by

LOCKHEED MARTIN ENERGY RESEARCH CORP.

for the

U.S. DEPARTMENT OF ENERGY

under contract DE-AC05-96OR22464 


\section{CONTENTS}

Page

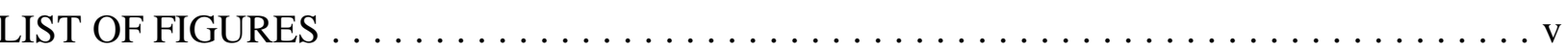

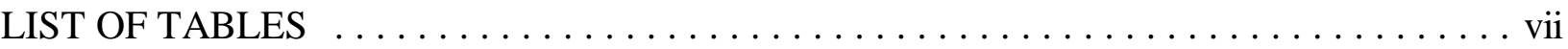

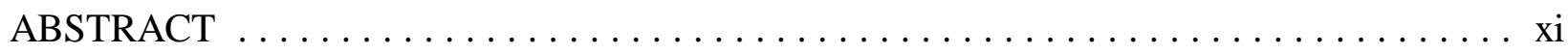

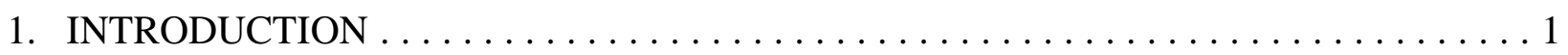

2. BWR FUEL ASSEMBLY DATA FOR DEPLETION ANALYSES $\ldots \ldots \ldots \ldots \ldots$

2.1 COOPER BWR SPENT FUEL DESIGN AND OPERATION DATA $\ldots \ldots \ldots \ldots 5$

2.2 GUNDREMMINGEN BWR SPENT FUEL DESIGN AND OPERATING DATA . 10

2.3 JPDR SPENT FUEL DESIGN AND OPERATING DATA $\ldots \ldots \ldots \ldots \ldots . .14$

3. PREDICTED AND MEASURED ISOTOPIC COMPOSITIONS $\ldots \ldots \ldots \ldots \ldots \ldots 23$

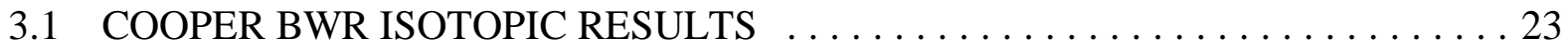

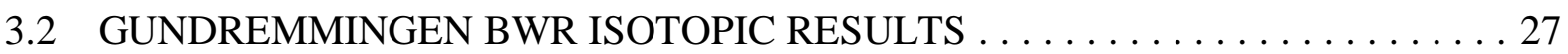

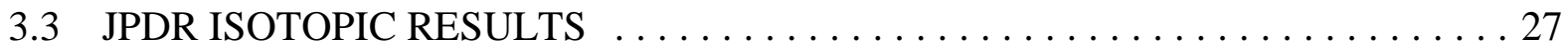

$3.4 \quad$ SUMMARY OF ISOTOPIC COMPARISON RESULTS $\ldots \ldots \ldots \ldots \ldots \ldots \ldots . \ldots \ldots$

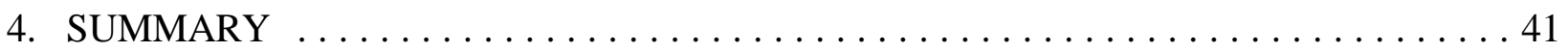

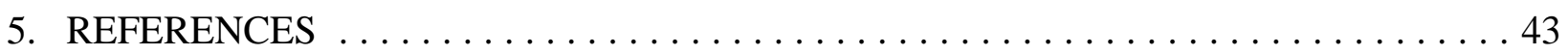

APPENDIX A - DESCRIPTION OF THE SCALE SAS2H DEPLETION APPROACH $\ldots 47$

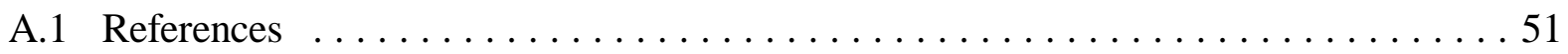

APPENDIX B- INPUT LISTINGS FOR COOPER BWR SAS2H DEPLETION

CALCULATIONS

APPENDIX C - INPUT LISTINGS FOR GUNDREMMINGEN BWR

SAS2H DEPLETION CALCULATIONS

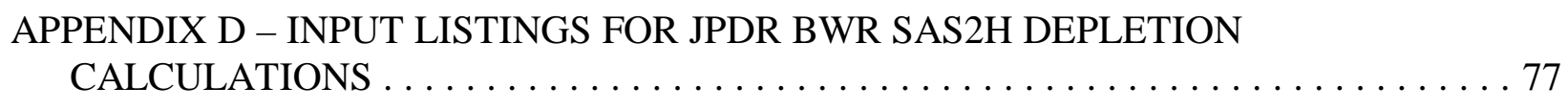

APPENDIX E - MEASURED AND COMPUTED ISOTOPIC CONCENTRATIONS

FOR COOPER BWR FUEL SAMPLES 
$\underline{\text { Page }}$

APPENDIX F - MEASURED AND COMPUTED ISOTOPIC CONCENTRATIONS

FOR GUNDREMMINGEN BWR FUEL SAMPLES

APPENDIX G - MEASURED AND COMPUTED ISOTOPIC CONCENTRATIONS

FOR JPDR BWR FUEL SAMPLES

APPENDIX H - SENSITIVITY OF CALCULATED CONCENTRATIONS

TO ASSUMED MODERATOR DENSITY . . . . . . . . . . . . . . . . . 121 


\section{LIST OF FIGURES}

\section{$\underline{\text { Figure }}$}

Page

1. Location of different type fuel rods in Assembly CZ346 of Cooper BWR. . . . . . . . . . 7

2. Loading diagram of Assembly CZ346 showing fuel rods analyzed. . . . . . . . . . 7

3. Locations of fuel rods analyzed in Assembly B23 of Gundremmingen BWR. . . . . . . . 12

4. Locations of fuel rods analyzed in Assembly C16 of Gundremmingen BWR. . . . . . . . 12

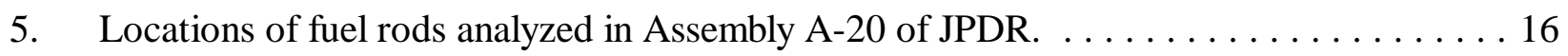

6. $\quad$ Percentage differences between measured and calculated results

for Cooper fuel samples. . . . . . . . . . . . . . . . . . . . . . 26

7. $\quad$ Percentage differences between measured and calculated results

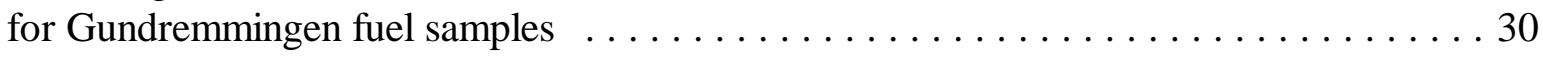

8. Percentage differences between measured and calculated results

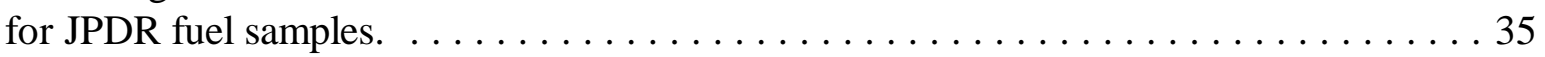

9. $\quad$ Percentage differences between measured and calculated results for all fuel samples. . . . 38

10. Standard deviation of isotopic prediction results by reactor type . . . . . . . . . . 39

A.1. Flow path invoked in SAS2H depletion and decay sequences. . . . . . . . . . . . 49 


\section{LIST OF TABLES}

\section{$\underline{\text { Table }}$}

Page

1. $\quad$ Basic parameters of the measured spent fuel $\ldots \ldots \ldots \ldots \ldots \ldots \ldots$

2. Design and temperature data for Cooper BWR fuel assemblies $\ldots \ldots \ldots \ldots$

3. Initial uranium composition of Cooper BWR fuel samples $\ldots \ldots \ldots \ldots \ldots$

4. Operating data for Cooper BWR Assembly CZ346 and fuel pellet samples ........9

5. $\quad$ Effective geometry for Cooper assembly model $\ldots \ldots \ldots \ldots \ldots \ldots \ldots$

6. Design and temperature data for Gundremmingen BWR fuel assemblies $\ldots \ldots \ldots \ldots 11$

7. Initial uranium composition of Gundremmingen BWR fuel samples $\ldots \ldots \ldots \ldots \ldots$

8. Operating data for Gundremmingen BWR

Assemblies B23 and $\mathrm{C} 16$ and fuel pellet samples $\ldots \ldots \ldots \ldots \ldots \ldots \ldots \ldots$

9. $\quad$ Effective geometry for Gundremmingen assembly model . . . . . . . . . . . . . 14

10. Design and temperature data for JPDR fuel assemblies $\ldots \ldots \ldots \ldots \ldots \ldots$

11. Initial uranium composition of JPDR fuel samples $\ldots \ldots \ldots \ldots \ldots \ldots \ldots$

12. Operating data for JPDR fuel samples from Assemblies A-14, A-18,

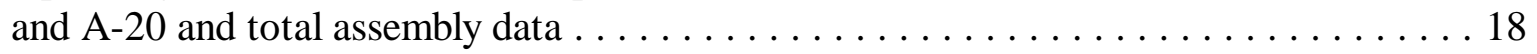

13. Example of power history applied in SAS2H depletion model of

Assembly A-14, node $2 \ldots \ldots \ldots$. . . . . . . . . . . . . . . . . . . . .

14. Exposure uptimes and downtimes of power history

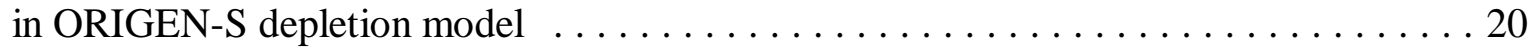

15. $\quad$ Effective geometry for JPDR assembly model $\ldots \ldots \ldots \ldots \ldots \ldots \ldots$

16. Measured irradiation composition, in $\mathrm{g} / \mathrm{g} \mathrm{UO}$, of Cooper BWR fuel . . . . . . . . . 24

17. Measured irradiation composition, in $\mathrm{Ci} / \mathrm{g} \mathrm{UO}_{2}$, of Cooper BWR fuel $\ldots \ldots \ldots \ldots 24$ 
18. $\quad$ Percentage difference between measured and computed nuclide compositions for Cooper BWR samples and averages from Assembly CZ346 ...................................... 25

19. Average measured irradiation composition of Gundremmingen BWR fuel ........ 28

20. $\quad$ Percentage difference between measured and computed nuclide compositions for Gundremmingen BWR samples and averages from Assemblies B23 and C16 .............................

21. Measured irradiation composition of JPDR spent fuel from eight samples $\ldots \ldots \ldots$. . 31

22. Measured irradiation composition of JPDR spent fuel from eight additional samples _ . 32

23. Percentage difference between measured and computed nuclide composition for JPDR samples and averages from Assemblies A-14, A-18, and A-20 ............. 33

24. Summary of percentage differences between measured and computed composition in this BWR validation study as averages and spreads $\ldots \ldots \ldots \ldots 36$

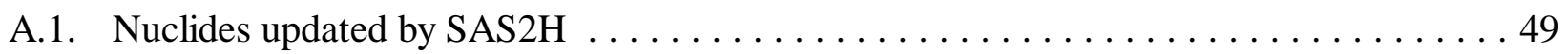

A.2. Element contents from clad, structure, and moderator for a generic BWR $\ldots \ldots \ldots$... 51

H.1. Sensitivity of predicted concentrations to moderator density for a low-average-density Cooper fuel sample ....................... 123

H.2. Sensitivity of predicted concentrations to moderator density for a high-average-density Cooper fuel sample . . . . . . . . . . . . . . . . . . . . . . 124

H.3. Sensitivity of predicted concentrations to moderator density for a low-average-density Gundremmingen fuel sample

H.4. Sensitivity of predicted concentrations to moderator density for a high-average-density Gundremmingen fuel sample

H.5. Sensitivity of predicted-to-measured ratios to moderator density for a low-average-density Cooper fuel sample . . . . . . . . . . . . . . . . . . 127

H.6. Sensitivity of predicted-to-measured ratios to moderator density for a high-average-density Cooper fuel sample 
H.7. Sensitivity of predicted-to-measured ratios to moderator density for a low-average-density Gundremmingen fuel sample . . . . . . . . . . . . . . . . . 129

H.8. Sensitivity of predicted-to-measured ratios to moderator density for a high-average-density Gundremmingen fuel sample . . . . . . . . . . . . . . 130 


\begin{abstract}
Thirty spent fuel samples obtained from boiling-water-reactor (BWR) fuel pins have been modeled at Oak Ridge National Laboratory using the SAS2H sequence of the SCALE code system. The SAS2H sequence uses transport methods combined with the depletion and decay capabilities of the ORIGEN-S code to estimate the isotopic composition of fuel as a function of its burnup history. Results of these calculations are compared with chemical assay measurements of spent fuel inventories for each sample. Results show reasonable agreement between measured and predicted isotopic concentrations for important actinides; however, little data are available for most fission products considered to be important for spent fuel concerns (e.g., burnup credit, shielding, source-term calculations, etc.).

This work is a follow-up to earlier works that studied the ability to predict spent fuel compositions in pressurized-water-reactor (PWR) fuel pins. Biases and uncertainties associated with BWR isotopic predictions are found to be larger than those of PWR calculations. Such behavior is expected, as the operation of a BWR is significantly more complex than that of a PWR plant, and in general the design of a BWR has a more heterogeneous configuration than that of a PWR. Nevertheless, this work shows that the simple models employed using SAS2H to represent such complexities result in agreement to within 5\% (and often less than 1\%) or less for most nuclides important for spent fuel applications. On the other hand, however, the set of fuel samples analyzed represent a small subset of the BWR fuel population, and results reported herein may not be representative of the full population of BWR spent fuel.
\end{abstract}




\section{INTRODUCTION}

Accurate prediction of the isotopic composition of light-water-reactor (LWR) spent fuel is essential in the design, licensing, and operation of radioactive waste transportation systems, interim storage, and a permanent repository. An accurate determination of the time-dependent isotopic concentrations in spent fuel is required in evaluating (1) neutron multiplication for criticality safety, (2) neutron and gamma-ray source terms for shielding analyses, (3) decay-heat source terms for safety regarding temperature or heat transfer, and (4) radiological and chemical toxicity terms for environmental considerations. One of the functions of the SCALE ( $\underline{\text { Standardized }}$ Computer Analyses for Licensing Evaluation) code systen ${ }^{1}$ is the capability to predict the isotopic composition of LWR spent fuel. Recent applications of nuclide depletion and production computations for LWR fuel include criticality safety analyses for investigation of storage or shipment of spent fuel $2-5$ The ANSI/ANS-8.1 criticality standard 6 requires the validation of the analytical methods used in these spent fuel criticality analyses. The purpose of this report is to describe efforts to validate the capability of the SCALE system, Version 4.3, to predict the isotopic composition of boiling-waterreactor (BWR) spent fuel. Complementary report $\$-9$ describe similar efforts to validate the use of the SCALE depletion analysis for the prediction of nuclide inventory of pressurized-water-reactor (PWR) spent fuel.

The 30 fuel samples analyzed in this study were taken from six separate fuel assemblies of three different BWRs: the Cooper Nuclear Power Plant (USA), the Gundremmingen Nuclear Power Plant (Germany), and the Japan Power Demonstration Reactor (JPDR). Radiochemical analyse 10 of six Cooper fuel samples were conducted by the Material Characteristics Center (MCC) at Pacific Northwest Laboratory (PNL). The eight Gundremmingen fuel samples included in this work were analyzed by the European Joint Research Center (EJRC) at both the Ispra (Italy) and Karlsruhe

(Germany) facilities $\frac{11,12}{1}$ Sixteen fuel samples from the JPDR were selected and were analyzed by the Japanese Atomic Energy Research Institute (JAERI) 11 Even though not representative of most modern commercial BWR fuel designs and operating conditions, these data represent the majority of published and readily available BWR fuel assay data. 
The major parameters characterizing the fuels analyzed in this project cover a relatively wide range. The fuel burnups extend from 2.16 to $33.94 \mathrm{GWd} / \mathrm{MTU}$. The initial fuel enrichments of the samples vary from 2.53 to $2.94 \mathrm{wt} \%{ }^{235} \mathrm{U}$. The BWR designs include both $6 \times 6$ and $7 \times 7$ assembly lattices, and the active fuel lengths vary from 146.6 to $370.8 \mathrm{~cm}$. The sample fuel pellets were burned with specific powers ranging from 3.74 to $25.34 \mathrm{MW} / \mathrm{MTU}$, and were selected from a range of axial positions in the fuel such that average moderator densities ranged from 0.31 to $0.77 \mathrm{~g} / \mathrm{cm}^{3}$.

The calculated (predicted) isotopic concentrations reported herein were produced by the SAS2H control module in Version 4.3 of the SCALE code system! 1 This control module produces burnup-dependent cross sections using the one-dimensional (1-D) neutronics model processing in SCALE and the fuel-depletion analysis of the ORIGEN-S code. Details of the procedure are described in Appendix A.

The cross-section library applied in these analyses was the SCALE 44-group library, produced from Evaluated Nuclear Data Files (ENDF) 13 The 44-group library ${ }^{14}$ was derived from ENDF/B-V data, with the exception of three nuclides. The cross sections for ${ }^{16} \mathrm{O},{ }^{154} \mathrm{Eu}$, and ${ }^{155} \mathrm{Eu}$ in this library were obtained from ENDF/B-VI files. The ENDF/B-VI files provided data with a significant change to resonance region cross sections for ${ }^{154} \mathrm{Eu}$ and ${ }^{155} \mathrm{Eu}$ ref. 15. The newer ${ }^{154} \mathrm{Eu}$ evaluation results in better estimates of source terms for shielding calculations. The revised ${ }^{155} \mathrm{Eu}$ evaluation provides a better estimate of post-shutdown ${ }^{155} \mathrm{Gd}$ buildup from ${ }^{155} \mathrm{Eu}$ decay. The ${ }^{16} \mathrm{O}$ change involved improvements in the scattering kernel and is insignificant in the analyses described in this report.

The remainder of this report is divided into three sections: Sect. 2 furnishes a detailed description of the SAS2H fuel assembly models used to represent each fuel sample studied. In Sect. 3, results of comparisons of the predicted and measured isotopic composition are presented. Finally, the significance and limitations of these analyses are discussed in Sect. 4, together with recommendations for future work. 


\section{BWR FUEL ASSEMBLY DATA FOR DEPLETION ANALYSES}

The 30 spent fuel cases selected as a basis for the SCALE-4.3 depletion analyses in this validation study were selected from radioactive assay data for spent fuel samples from the Cooper, Gundremmingen, and JPDR BWRs. The primary parameters that characterize spent fuel samples are initial ${ }^{235} \mathrm{U}$ enrichment, accumulated burnup, axial location or height, and moderator density at the fuel sample height. Table 1 summarizes the values of each of these parameters for the six samples from the Cooper BWR, the eight samples from two Gundremmingen assemblies, and the 16 fuel pellets from three assemblies of the JPDR. Although certainly not all-inclusive, these parameters bound operational parameters for a large fraction of BWR spent fuel. The low-toreasonably-high burnups of the samples are considered to be adequate for statistical evaluation. Note, however, that the design of the fuel assemblies is generally atypical of the population of BWR fuel designs (e.g., the assemblies used axially uniform fuel enrichments, both Cooper and JPDR used uniform fuel loadings across the assembly, none of the fuel assemblies had water holes, and all were operated differently than most modern BWR fuel assemblies).

Because of several significantly different design and operational aspects of a BWR relative to PWR designs, other core parameters must be considered in BWR assembly models that have not been necessary in PWR models. Specifically, BWR models must accommodate assembly cross-plane (x-y) nonuniformities, control rod insertion, and moderator density variations due to assembly flow channels.

The coolant density at the axial height of the pellet sample is a required input parameter for the depletion calculation. However, the explicit coolant density data required for the calculation are seldom available in the open literature. In order to be consistent within this validation study, a method for estimating the coolant density was developed that applies design and operating parameters that were included in each set of data. Essentially, a correlation between power and moderator density as a function of height was developed. Water densities assumed for each axial location, calculated using this method, are listed in Table 1 for each fuel sample. 
Table 1. Basic parameters of the measured spent fuel

\begin{tabular}{|c|c|c|c|c|c|c|c|}
\hline No. & Unit name & $\begin{array}{c}\text { Test } \\
\text { assembly } \\
\text { (pin No.) }\end{array}$ & $\begin{array}{c}\text { Initial } \\
\text { enrichment } \\
\left.\text { (wt } \%{ }^{235} \mathrm{U}\right)\end{array}$ & $\begin{array}{c}\text { Axial } \\
\text { level or } \\
\text { node No. }\end{array}$ & $\begin{array}{l}\text { Axial } \\
\text { height }^{a} \\
(\mathrm{~cm})\end{array}$ & $\begin{array}{c}\text { Burnup } \\
\text { (GWd/MTU) }\end{array}$ & $\begin{array}{c}\text { Moderator } \\
\text { density } \\
\left(\mathrm{g} / \mathrm{cm}^{3}\right)\end{array}$ \\
\hline 1 & Cooper & CZ346(B3) & 2.939 & Cut B & 351.7 & 18.96 & 0.3446 \\
\hline 2 & & & & Cut K & 186.9 & 33.07 & 0.4705 \\
\hline 3 & & & & Cut T & 131.0 & 33.94 & 0.5736 \\
\hline 4 & & CZ346(C3) & & Cut B & 350.1 & 17.84 & 0.3452 \\
\hline 5 & & & & Cut $\mathbf{J}$ & 290.7 & 29.23 & 0.3723 \\
\hline 6 & & & & Cut U & 114.7 & 31.04 & 0.6124 \\
\hline 7 & Gundremmingen & B23(A1) & 2.530 & Low & 44.0 & 25.73 & 0.7378 \\
\hline 8 & & & & High & 268.0 & 27.40 & 0.3145 \\
\hline 9 & & B23(B3) & & High & 268.0 & 21.24 & 0.3145 \\
\hline 10 & & B23(E3) & & High & 268.0 & 23.51 & 0.3145 \\
\hline 11 & Gundremmingen & $\mathrm{C} 16(\mathrm{~A} 1)$ & 2.530 & Low & 44.0 & 20.30 & 0.7460 \\
\hline 12 & & & & High & 268.0 & 19.85 & 0.3849 \\
\hline 13 & & C16(B3) & & High & 268.0 & 14.39 & 0.3849 \\
\hline 14 & & C16(E5) & & High & 268.0 & 17.49 & 0.3849 \\
\hline 15 & JPDR & $\mathrm{A}-14^{b}$ & 2.596 & 2 & 129.6 & 3.30 & 0.6075 \\
\hline 16 & & & & 9 & 44.0 & 4.04 & 0.7541 \\
\hline 17 & JPDR & $\mathrm{A}-18^{b}$ & 2.596 & 2 & 129.6 & 2.71 & 0.5629 \\
\hline 18 & & & & 6 & 80.7 & 4.25 & 0.6708 \\
\hline 19 & JPDR & $\mathrm{A}-20(\mathrm{~A} 1)$ & 2.596 & 3 & 117.4 & 7.01 & 0.6719 \\
\hline 20 & & A-20(A3) & & 10 & 31.8 & 6.15 & 0.7642 \\
\hline 21 & & A-20(A6) & & 3 & 117.4 & 6.95 & 0.6719 \\
\hline 22 & & & & 9 & 44.0 & 6.51 & 0.7600 \\
\hline 23 & & $\mathrm{~A}-20(\mathrm{C} 3)$ & & 1 & 141.8 & 2.65 & 0.5232 \\
\hline 24 & & & & 3 & 117.4 & 5.09 & 0.5688 \\
\hline 25 & & & & 5 & 92.9 & 6.08 & 0.6276 \\
\hline 26 & & & & 8 & 56.2 & 6.04 & 0.7305 \\
\hline 27 & & & & 10 & 31.8 & 5.06 & 0.7534 \\
\hline 28 & & & & 12 & 7.3 & 2.16 & 0.7701 \\
\hline 29 & & A-20(E2) & & 3 & 117.4 & 5.60 & 0.5688 \\
\hline 30 & & & & 10 & 31.8 & 5.38 & 0.7534 \\
\hline
\end{tabular}

${ }^{a}$ Height of sample above bottom of fuel.

${ }^{b}$ Pin identified only as one of rods in the center part of assembly. 
Although BWR designs tend to be more inhomogeneous and asymmetric than PWR designs, the 1-D XSDRNPM assembly model used for transport solutions and cross-section weighting, combined with the point depletion approach of ORIGEN-S (based on an assembly-averaged model), requires geometric simplifications and assumptions similar to those applied in PWR depletion modeling. Each fuel assembly was therefore modeled as a set of concentric rings, using engineering judgement in representing key features of the specific assembly design. Special treatment of control rod insertion is also necessary to properly account for system reactivity. Partial (usually small) control rod insertion is common in BWRs, especially early in a fuel cycle. Unfortunately, rod-positioning data are rarely available in documentation of fuel- assay data, nor is SAS2H designed to explicitly model partial control rod insertion. In an earlier validation effort for BWR decay heat

estimates 16 a procedure was developed where an assembly-averaged model was set up, and boron was added to the moderator material at a concentration such that the average of all values of $\mathrm{k}_{\text {eff }}$ calculated for each cycle was close to unity. Hence the soluble boron was in effect matching the reactivity of control rod insertion in maintaining a critical system. This approach was used in the Gundremmigen analyses, but was not deemed necessary for the other reactor fuel assemblies.

The approximations made to represent absorber rods and general assembly design characteristics varied for each assembly type and are detailed in the following subsections, which describe the specific attributes of each assembly design. Other design-specific modeling assumptions or approximations are also detailed for each assembly design.

\subsection{COOPER BWR SPENT FUEL DESIGN AND OPERATION DATA}

The Cooper Nuclear Power Plant, operated by the Nebraska Public Power District, used General Electric BWR fuel assemblies with a $7 \times 7$ pin lattice for the fuel cycles analyzed in this report. The fuel rod lattice data and other fuel assembly design and operating characteristics, obtained from refs. 10 and 16-19, are listed in Table 2. A fuel bundle map and a partial loading diagram of assembly CZ346 are shown in Figs. 1 and 2, respectively. Three sample pellets from each of two rods were used in the radiochemical analyses. 
Table 2. Design and temperature data for Cooper BWR fuel assemblies

\begin{tabular}{|c|c|}
\hline Parameter & Data \\
\hline $\begin{array}{l}\text { Assembly general data } \\
\text { Designer } \\
\text { Lattice, version } \\
\text { Equivalent core diameter, cm (in.) } \\
\text { Number of fuel rods } \\
\text { Number with } 2.939 \mathrm{wt} \%{ }^{235} \mathrm{U} \\
\text { Number with } 1.94 \mathrm{wt} \%{ }^{235} \mathrm{U} \\
\text { Number with } 1.69 \mathrm{wt} \%{ }^{235} \mathrm{U} \\
\text { Number with } 1.33 \mathrm{wt} \%{ }^{235} \mathrm{U} \\
\text { Number of rods containing Gd } \\
\text { Number with } 3.0 \mathrm{wt} \% \mathrm{Gd}_{2} \mathrm{O}_{3} \\
\text { Number with } 4.0 \mathrm{wt} \% \mathrm{Gd}_{2} \mathrm{O}_{3} \\
\text { Channel tube thickness, cm (in.) } \\
\text { Assembly pitch, cm (in.) } \\
\text { Coolant inlet temperature, } \mathrm{K} \\
\text { Coolant average temperature, } \mathrm{K} \\
\text { Channel temperature, } \mathrm{K} \\
\text { Channel tube material } \\
\text { Channel tube temperature, } \mathrm{K} \\
\text { Assembly fuel, kg U }\end{array}$ & $\begin{array}{l}\text { General Electric } \\
7 \times 7, \text { GE-3b } \\
402(158) \\
49 \\
30 \\
12 \\
6 \\
1 \\
5 \\
3 \\
2 \\
0.20(0.08) \\
15.24(6.0) \\
546^{a} \\
558^{b} \\
552^{b} \\
\text { Zircaloy-4 }_{558^{b}} \\
190.71^{c}\end{array}$ \\
\hline $\begin{array}{l}\text { Fuel rod data } \\
\text { Type fuel pellet } \\
\text { Hot pellet density, }{ }^{\mathrm{d}} \mathrm{g} / \mathrm{cm}^{3} \\
\text { Rod pitch, cm (in.) } \\
\text { Rod OD, cm (in.) } \\
\text { Rod ID, cm (in.) } \\
\text { Hot pellet diameter, cm (in.) } \\
\text { Active fuel length, cm (in.) } \\
\text { Effective fuel temperature, K } \\
\text { Clad temperature, K } \\
\text { Clad material }\end{array}$ & $\begin{array}{l}\mathrm{UO}_{2} \\
9.73 \\
1.875(0.738) \\
1.430(0.563) \\
1.242(0.489) \\
1.242(0.489) \\
370.84(146) \\
840^{b} \\
620^{b} \\
\text { Zircaloy-2 }\end{array}$ \\
\hline
\end{tabular}

${ }^{a}$ Obtained using a linear extrapolation of the average and maximum inlet temperatures in generic BWR data from ref. 19.

${ }^{b}$ Fuel, coolant, and clad temperatures were not available in the literature. Temperatures given in generic BWR data from refs. 16 and 19 were applied.

${ }^{c}$ Computed from other data in this table.

${ }^{d}$ Assumed $1 \%$ dishing of pellet. Applied hot fuel diameter equal to rod ID. Sources: Refs. 10, 16-19. 


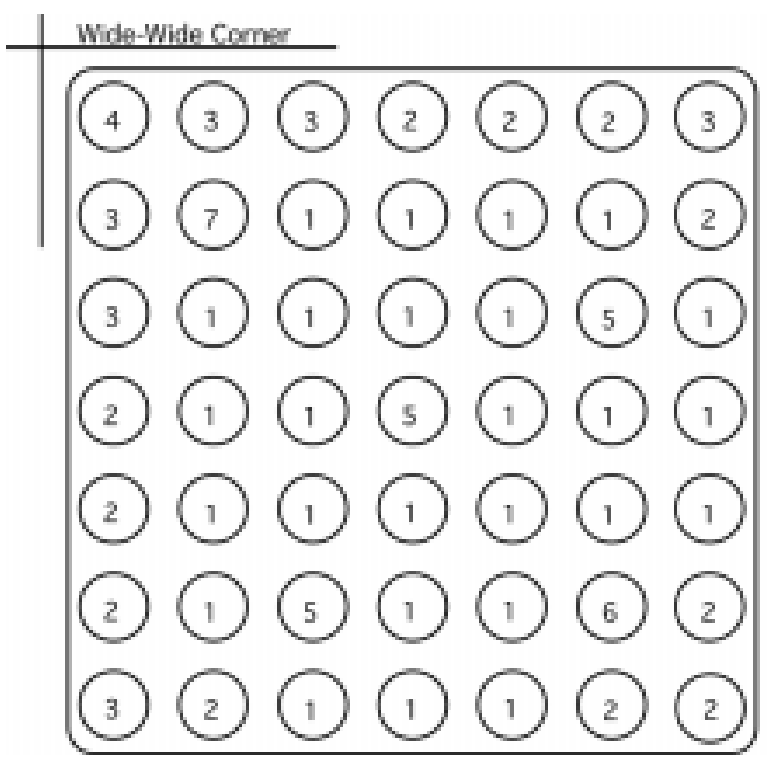

\begin{tabular}{|c|c|c|c|}
\hline Rod Type & $\begin{array}{c}\text { Enrichment } \\
\left(w t \% \text { 23S }^{23}\right.\end{array}$ & $\begin{array}{c}W \mathrm{t} \% \\
\mathrm{Gd}_{2} \mathrm{O}_{3}\end{array}$ & $\begin{array}{c}\text { Number } \\
\text { of Rods }\end{array}$ \\
\hline 1 & 2.93 & 0 & 26 \\
\hline 2 & 1.94 & 0 & 11 \\
\hline 3 & 1.69 & 0 & 6 \\
\hline 4 & 1.33 & 0 & 1 \\
\hline 5 & 2.93 & 3.0 & 3 \\
\hline 6 & 2.93 & 4.0 & 1 \\
\hline 7 & 1.94 & 4.0 & 1 \\
\hline
\end{tabular}

Fig. 1. Location of different type fuel rods in Assembly CZ346 of Cooper BWR.

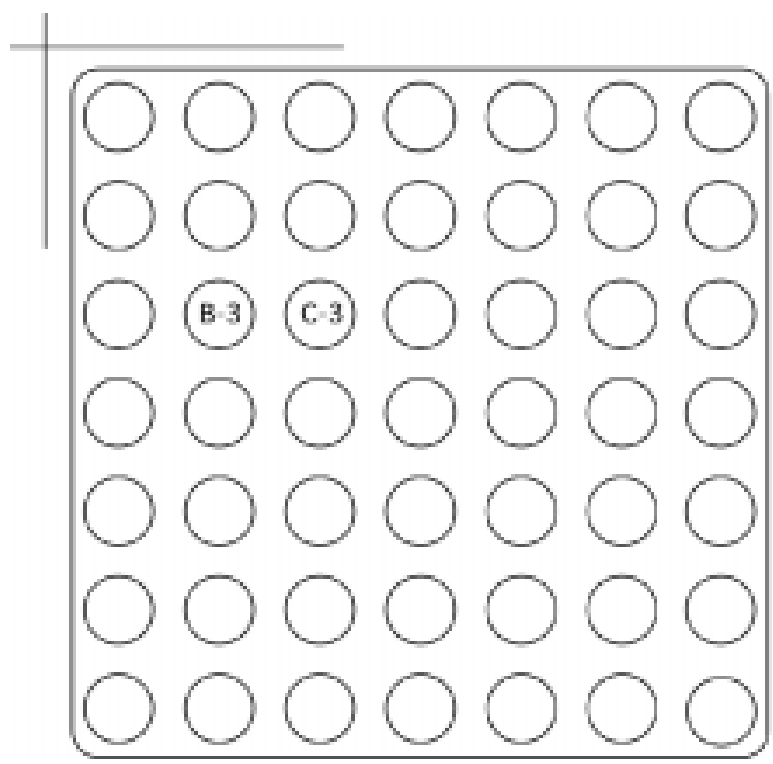

Fig. 2. Loading diagram of Assembly CZ346 showing fuel rods analyzed. 
The initial uranium isotopic composition of the sample fuel rods is listed in Table 3. The initial weight fraction of ${ }^{235} \mathrm{U}$ was obtained from ref. 10; the fractions of the remaining uranium isotopes were estimated from the wt $\%{ }^{235} \mathrm{U}$ value by empirical relationships developed in earlier ion validation work 16 Although the Cooper design (like most BWR fuel assemblies) contained multiple enrichments, the depletion calculational procedure in the SAS2H control module does not accommodate more than a single initial composition. Therefore, it was also assumed that the assembly contained a uniform loading corresponding to the enrichment of the sample pin. Although this approximation may not produce accurate assembly-averaged flux spectra, the depletion solution is primarily driven by initial conditions. Hence to estimate the time-dependent composition of a specific fuel sample, it is imperative to begin calculations with the correct initial composition of that sample.

Table 3. Initial uranium composition of Cooper BWR fuel samples

\begin{tabular}{c|c}
\hline Uranium isotope & $\begin{array}{c}\text { Assembly CZ346, } \\
\text { rods at B3 and C3 } \\
(\mathrm{wt} \%)\end{array}$ \\
\hline${ }^{235} \mathrm{U}$ & 2.939 \\
${ }^{234} \mathrm{U}$ & 0.026 \\
${ }^{236} \mathrm{U}$ & 0.014 \\
${ }^{238} \mathrm{U}$ & 97.021 \\
\hline
\end{tabular}

The operating histories of Assembly $\mathrm{CZ}_{3} 46^{10}$ and each fuel sample are shown in Table 4 . Reference data provided cumulative burnup per cycle of the assembly and the estimated final burnup of each sample. Cycle burnups for each sample were estimated assuming each sample was burned at the same relative rate as the full assembly. Thus pin burnups per cycle were obtained by normalizing the assembly burnup history and multiplying by the final sample burnup. The cycle-averaged power in each pin was then obtained by dividing the pin burnup by the cycle length for each cycle. The values in Table 4 are not meant to indicate a precision of three significant digits for burnups; they simply indicate the number of digits retained in local burnup estimates. 
Table 4. Operating data for Cooper BWR Assembly CZ346 and fuel pellet samples

\begin{tabular}{|c|c|c|c|c|c|}
\hline Cycle No. & 1 & 2 & 3 & 6 & 7 \\
\hline Startup date & $7 / 4 / 74$ & $11 / 16 / 76$ & $10 / 18 / 77$ & $6 / 8 / 80$ & $6 / 8 / 81$ \\
\hline Shutdown date & $9 / 17 / 76$ & $9 / 17 / 77$ & $3 / 31 / 78$ & $4 / 20 / 81$ & $5 / 21 / 82$ \\
\hline Cycle length, $\mathrm{d}$ & 806 & 306 & 165 & 317 & 347 \\
\hline Downtime, $\mathrm{d}$ & 60 & 31 & 800 & 49 & 0 \\
\hline Assembly burnup, GWd/MTU & & & & & \\
\hline Cumulative & 13.90 & 19.14 & 21.92 & 25.20 & 28.05 \\
\hline Increment/cycle & 13.90 & 5.24 & 2.78 & 3.28 & 2.85 \\
\hline Cycle burnup, GWd/MTU & & & & & \\
\hline Rod ADD2966(B3), $351.7 \mathrm{~cm}$ & 9.396 & 3.542 & 1.879 & 2.217 & 1.926 \\
\hline Rod ADD2966(B3), $186.9 \mathrm{~cm}$ & 16.388 & 6.178 & 3.278 & 3.867 & 3.360 \\
\hline Rod ADD2966(B3), $131.0 \mathrm{~cm}$ & 16.819 & 6.34 & 3.364 & 3.969 & 3.448 \\
\hline Rod ADD2974(C3), $350.1 \mathrm{~cm}$ & 8.840 & 3.333 & 1.768 & 2.086 & 1.813 \\
\hline Rod ADD2574(C3), $290.7 \mathrm{~cm}$ & 14.485 & 5.460 & 2.897 & 3.418 & 2.970 \\
\hline Rod ADD2974(C3), $114.7 \mathrm{~cm}$ & 15.382 & 5.799 & 3.076 & 3.630 & 3.154 \\
\hline $\begin{array}{l}\text { Cycle average power, } \\
{\mathrm{MW} / \mathrm{MTUO}_{2}}\end{array}$ & & & & & \\
\hline Assembly CZ346 (full) & 17.246 & 17.124 & 16.848 & 10.347 & 8.213 \\
\hline Rod ADD2966(B3), $351.7 \mathrm{~cm}$ & 10.275 & 10.203 & 10.039 & 6.165 & 4.894 \\
\hline Rod ADD2966(B3), $186.9 \mathrm{~cm}$ & 17.922 & 17.796 & 17.509 & 10.753 & 8.535 \\
\hline Rod ADD2966(B3), $131.0 \mathrm{~cm}$ & 18.394 & 18.264 & 17.970 & 11.036 & 8.760 \\
\hline Rod ADD2974(C3), $350.1 \mathrm{~cm}$ & 9.668 & 9.600 & 9.446 & 5.801 & 4.605 \\
\hline Rod ADD2974(C3), $290.7 \mathrm{~cm}$ & 15.841 & 15.729 & 15.476 & 9.504 & 7.544 \\
\hline Rod ADD2974(C3), $114.7 \mathrm{~cm}$ & 16.822 & 16.703 & 16.435 & 10.093 & 8.011 \\
\hline
\end{tabular}

Source: Ref. 10.

A model of the full assembly CZ346 was developed to determine the soluble boron concentration necessary to create a system operated at a $\mathrm{k}_{\mathrm{eff}}$ value near unity. An average moderator density of $0.5151 \mathrm{~g} / \mathrm{cm}^{3}$ and an average assembly enrichment of $2.5086 \mathrm{wt} \%$ were derived from available data. The specific powers listed in Table 4 for the full assembly were applied. The resulting calculations showed that $\mathrm{k}_{\text {eff }}$ was sufficiently close to unity (within a few percent); thus, a soluble boron addition was not deemed necessary for Cooper models. 
The assembly unit cell model used in Path B of SAS2H applied an average $\mathrm{Gd}_{2} \mathrm{O}_{3}-\mathrm{UO}_{2}$ fuel pin at the center of the model. One-fifth of the assembly and associated channel were used per cell because there were five gadolinium rods in the assembly design. Applying one-fifth of the cross-sectional area of all materials of the assembly and channel, the zone radii of the assembly model were determined, as listed in Table 5. SAS2H case inputs for the Cooper BWR models are provided in Appendix B.

Table 5. Effective geometry for Cooper assembly model

\begin{tabular}{c|l|c}
\hline Radial zone & \multicolumn{1}{|c|}{ Material } & Radius, cm \\
\hline 1 & $\mathrm{Gd}_{2} \mathrm{O}_{3}-\mathrm{UO}_{2}$ fuel & 0.621 \\
2 & $\mathrm{Clad}$ of fuel rod $_{3}$ & 0.715 \\
3 & Moderator outside Gd rod in unit cell & 1.058 \\
4 & Homogenized fuel, clad and moderator (of Path A) & 3.311 \\
5 & Channel tube & 3.412 \\
6 & Moderator outside of channel tube & 3.845 \\
\hline
\end{tabular}

\subsection{GUNDREMMINGEN BWR SPENT FUEL DESIGN AND OPERATING DATA}

The Gundremmingen Nuclear Power Plant, operated by Kenkraftwerk RWE-Bayernwerk $\mathrm{GmbH}(\mathrm{KRB})$, uses fuel assemblies with a $6 \times 6$ lattice. Data characterizing the assembly design and operating conditions for the Gundremmingen $\mathrm{BWR}^{11,12,16}$ are listed in Table 6. Assembly loading diagrams, depicting the selected sample rods for Assemblies B23 and C16, are shown in Figs. 3 and 4, respectively. Four sample pellets from each of two assemblies were used in this study.

The initial ${ }^{235} \mathrm{U}$ enrichmen $\mathbb{1 1}^{11}$ and the calculated ${ }^{16}$ concentrations of the other uranium isotopes are listed in Table 7. Operating power history data for the Assemblies B23 and C16 are given in Table 8. The cycle powers shown in the table for each sample were derived by a procedure similar to that used for the Cooper BWR power histories.

A full-assembly model of Assembly B23, using a volume-weighted moderator density of $0.5378 \mathrm{~g} / \mathrm{cm}^{3}$, the average enrichment of $2.402 \mathrm{wt} \%{ }^{235} \mathrm{U}$ and the power history for the B23 burnup, was used to estimate the ${ }^{10} \mathrm{~B}$ concentration of the channel moderator that would produce an average $\mathrm{k}_{\text {eff }}$ of approximately unity. $\mathrm{A}^{10} \mathrm{~B}$ concentration of $4 \times 10^{-5}$ atoms/barn-cm $\left(860 \mathrm{ppm}{ }^{10} \mathrm{~B}\right)$ was 
Table 6. Design and temperature data for Gundremmingen BWR fuel assemblies

\begin{tabular}{|c|c|}
\hline Parameter & Data \\
\hline $\begin{array}{l}\text { Assembly general data } \\
\text { Lattice } \\
\text { Equivalent core diameter, cm (in.) } \\
\text { Number of fuel rods } \\
\text { Number with } 2.53 \mathrm{wt} \%{ }^{235} \mathrm{U} \\
\text { Number with } 1.87 \mathrm{wt} \%{ }^{235} \mathrm{U} \\
\text { Channel tube thickness, } \mathrm{cm} \text { (in.) } \\
\text { Outer tube flat-to-flat, cm (in.) } \\
\text { Assembly pitch, cm (in.) } \\
\text { Coolant inlet temperature, } \mathrm{K} \\
\text { Coolant average temperature, } \mathrm{K} \\
\text { Channel temperature, } \mathrm{K} \\
\text { Channel tube material } \\
\text { Channel tube temperature, } \mathrm{K} \\
\text { Assembly (dished) fuel, } \mathrm{kg} \mathrm{UO}_{2}(\mathrm{~kg} \mathrm{U})\end{array}$ & $\begin{array}{l}6 \times 6 \\
274.8(108.2) \\
36 \\
29 \\
7 \\
0.15(0.059) \\
11.352(4.469) \\
13.098(5.157) \\
539 \\
549 \\
539 \\
\text { Zircaloy-4 } \\
549 \\
144(126.93)\end{array}$ \\
\hline 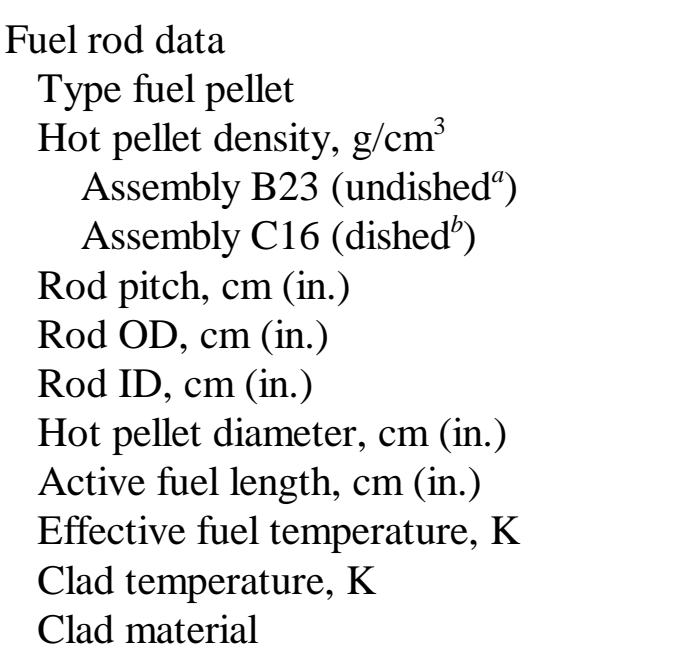 & $\begin{array}{l}\mathrm{UO}_{2} \\
10.068 \\
9.866^{c} \\
1.780(0.7008) \\
1.428(0.5622) \\
1.250(0.4922) \\
1.250(0.4922) \\
330.2(130.0) \\
923 \\
620^{d} \\
\text { Zircaloy-2 }\end{array}$ \\
\hline
\end{tabular}

${ }^{a}$ Reported as "undished."

${ }^{b}$ Reported as "dished." It is approximately $2 \%$ dishing.

'Computed from fuel mass and volume dimensions listed in this table.

${ }^{d}$ Clad temperature given in generic BWR data from ref. 19 was applied.

Sources: Refs. 11, 12, and 19. 


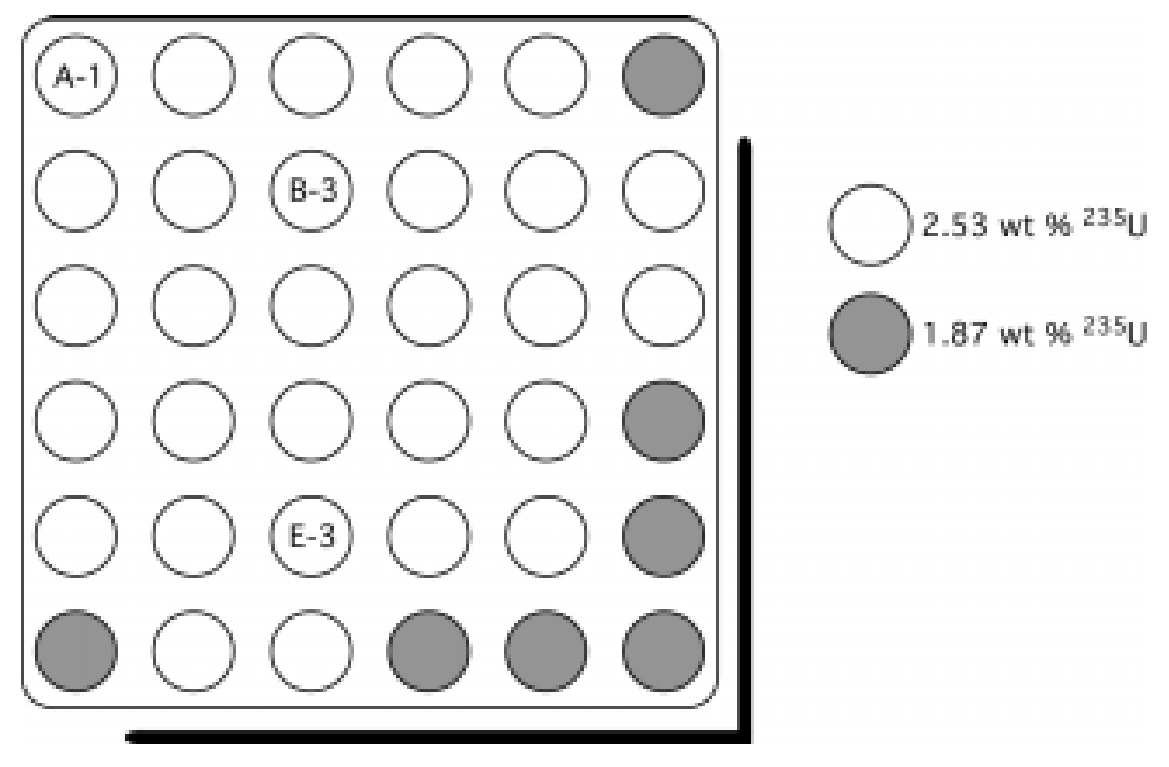

Fig. 3. Locations of fuel rods analyzed in Assembly B23 of Gundremmingen BWR.

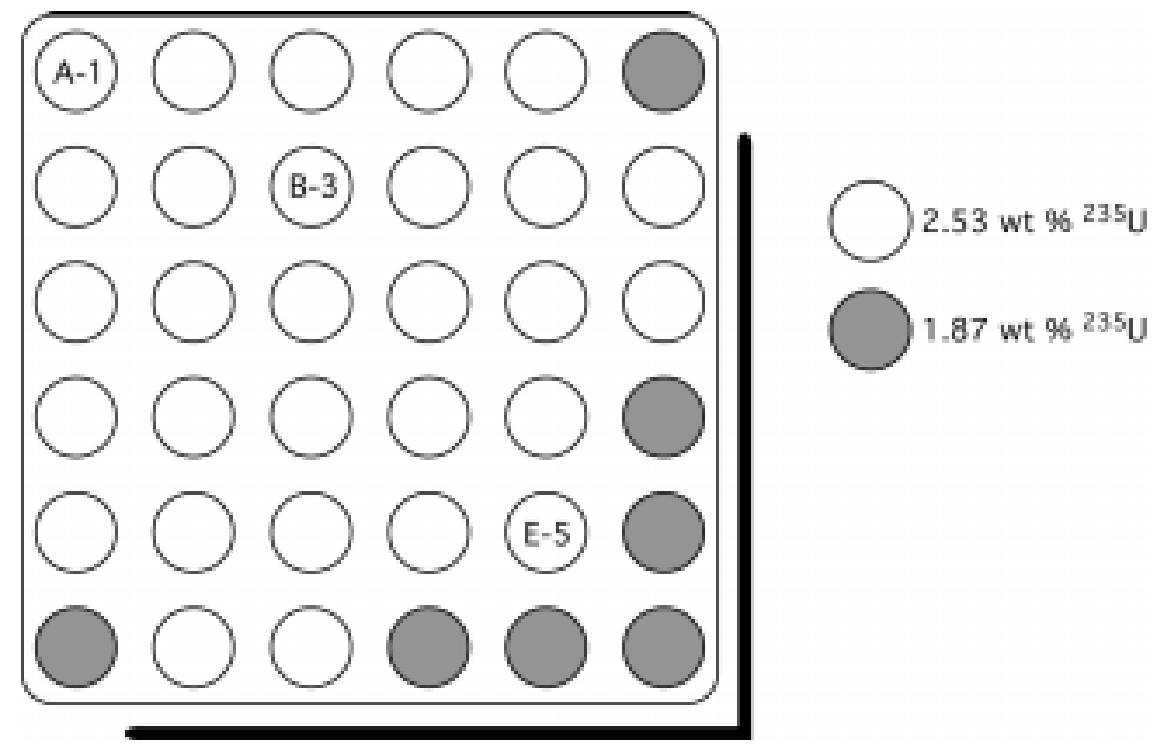

Fig. 4. Locations of fuel rods analyzed in Assembly C16 of Gundremmingen BWR. 
Table 7. Initial uranium composition of Gundremmingen BWR fuel samples

\begin{tabular}{c|c|c}
\hline & \multicolumn{2}{|c}{ Assembly ID } \\
\hline Uranium isotope & $\begin{array}{c}\text { B23 } \\
(\mathrm{wt} \%)\end{array}$ & $\begin{array}{c}\mathrm{C} 16 \\
(\mathrm{wt} \%)\end{array}$ \\
\hline${ }^{235} \mathrm{U}$ & 2.530 & 2.530 \\
${ }^{234} \mathrm{U}$ & 0.023 & 0.023 \\
${ }^{236} \mathrm{U}$ & 0.012 & 0.012 \\
${ }^{238} \mathrm{U}$ & 97.435 & 97.435 \\
\hline
\end{tabular}

Table 8. Operating data for Gundremmingen BWR

Assemblies B23 and C16 and fuel pellet samples

\begin{tabular}{|c|c|c|c|c|}
\hline Cycle No. & 2 & 3 & 4 & 5 \\
\hline Cycle length, $d$ & 279 & 323 & 290 & 309 \\
\hline Shutdown, d & 56 & 33 & 61 & 0 \\
\hline \multicolumn{5}{|c|}{ Cycle burnup, GWd/MTU } \\
\hline Assembly B23 & 5.839 & 6.131 & 5.483 & 5.174 \\
\hline Assembly C16 & $-^{a}$ & 5.959 & 5.083 & 6.026 \\
\hline \multicolumn{5}{|c|}{ Cycle burnup, GWd/MTU } \\
\hline $\mathrm{B} 23(\mathrm{~A} 1), 44 \mathrm{~cm}$ & 6.640 & 6.972 & 6.235 & 5.884 \\
\hline B23(A1), $268 \mathrm{~cm}$ & 7.071 & 7.424 & 6.640 & 6.265 \\
\hline B23(B3), $268 \mathrm{~cm}$ & 5.481 & 5.755 & 5.147 & 4.857 \\
\hline B23(E3), $268 \mathrm{~cm}$ & 6.067 & 6.370 & 5.697 & 5.376 \\
\hline $\mathrm{C} 16(\mathrm{~A} 1), 44 \mathrm{~cm}$ & - & 7.087 & 6.046 & 7.167 \\
\hline C16(A1), $268 \mathrm{~cm}$ & - & 6.930 & 5.912 & 7.008 \\
\hline C16(B3), $268 \mathrm{~cm}$ & - & 5.024 & 4.285 & 5.081 \\
\hline C16(E5), $268 \mathrm{~cm}$ & - & 6.106 & 5.209 & 6.175 \\
\hline \multicolumn{5}{|c|}{ Cycle average power, MW/MTU } \\
\hline Assembly B23 (full) & 20.928 & 18.981 & 18.907 & 16.744 \\
\hline $\mathrm{B} 23(\mathrm{~A} 1), 44 \mathrm{~cm}$ & 23.798 & 21.584 & 21.500 & 19.041 \\
\hline B23(A1), $268 \mathrm{~cm}$ & 25.343 & 22.985 & 22.895 & 20.276 \\
\hline B23(B3), $268 \mathrm{~cm}$ & 19.645 & 17.818 & 17.748 & 15.718 \\
\hline B23(E3), $268 \mathrm{~cm}$ & 21.745 & 19.722 & 19.645 & 17.398 \\
\hline $\mathrm{C} 16(\mathrm{~A} 1), 44 \mathrm{~cm}$ & - & 21.942 & 20.847 & 23.194 \\
\hline C16(A1), $268 \mathrm{~cm}$ & - & 21.456 & 20.384 & 22.680 \\
\hline C16(B3), $268 \mathrm{~cm}$ & - & 15.554 & 14.777 & 16.442 \\
\hline C16(E5), $268 \mathrm{~cm}$ & - & 18.905 & 17.961 & 19.984 \\
\hline
\end{tabular}

${ }^{a}$ Not present in core during cycle 2 . 
applied for the initial (fresh fuel) pass, and a concentration of $6 \times 10^{-6}$ atoms/barn-cm was applied for the remaining depletion passes.

The assembly unit cell model used in Path B of SAS2H applied 2.530 wt $\%{ }^{235} \mathrm{U}$ to the 36 fuel rods in the entire assembly because that was the initial enrichment of the fuel samples. The material and radius of each zone in the assembly model, given in Table 9, were calculated by conserving material mass for assembly dimensions Table 6. SAS2H case inputs for the Gundremmingen BWR are listed in Appendix C

Table 9. Effective geometry for Gundremmingen assembly model

\begin{tabular}{c|l|c}
\hline Radial zone & \multicolumn{1}{|c|}{ Material } & \multicolumn{1}{|c}{\begin{tabular}{c}
\multicolumn{1}{|c}{ Radius } \\
$(\mathrm{cm})$
\end{tabular}} \\
\hline 1 & $\mathrm{UO}_{2}$ fuel & 0.6250 \\
2 & Clad of fuel rod & 0.7140 \\
3 & Moderator outside control rod of unit cell & 1.0043 \\
4 & Homogenized fuel, clad and moderator (of Path A) & 6.026 \\
5 & Low-density moderator & 6.235 \\
6 & Channel tube & 6.405 \\
7 & Borated moderator outside of channel tube & 7.390 \\
\hline
\end{tabular}

\subsection{JPDR SPENT FUEL DESIGN AND OPERATING DATA}

The JPDR, located at Tokai-mura, Ibaraki-ken, was the first nuclear power facility in Japan. JPDR measurement data, measured by JAERI, were taken from BWR fuel assemblies with a $6 \times 6$ pin lattice. The fuel rod lattice data and other fuel assembly design and operating characteristics ${ }^{11}$ are listed in Table 10. The locations of fuel rods selected for analyses are shown in Fig. 5 for assembly A-20. One rod out of the four rods in the center (i.e., C3, C4, D3, or D4) was selected for the measurements of Assemblies A-14 and A-18. 
Table 10. Design and temperature data for JPDR fuel assemblies

\begin{tabular}{|c|c|}
\hline Parameter & Data \\
\hline $\begin{array}{l}\text { Assembly general data } \\
\text { Lattice } \\
\text { Number of fuel rods } \\
\text { Equivalent core diameter, cm (in.) } \\
\text { Number of fuel assemblies/core } \\
\text { Channel tube thickness, cm (in.) } \\
\text { Outer tube flat-to-flat, cm (in.) } \\
\text { Assembly pitch, cm (in.) } \\
\text { Coolant average temperature, K } \\
\text { Channel temperature, K } \\
\text { Channel tube material } \\
\text { Channel tube temperature, K } \\
\text { Assembly fuel, kg U }\end{array}$ & $\begin{array}{l}6 \times 6 \\
36 \\
127(50) \\
72 \\
0.15(0.059)^{a} \\
12.445(4.90)^{a} \\
13.26(5.22)^{b} \\
550 \\
539^{c} \\
\text { Zircaloy }^{c} \\
550^{c} \\
58.807^{b}\end{array}$ \\
\hline $\begin{array}{l}\text { Fuel rod data } \\
\text { Type fuel pellet } \\
\text { Hot pellet density, g/cm³ } \\
\text { Rod pitch, cm (in.) } \\
\text { Rod OD, cm (in.) } \\
\text { Rod ID, cm (in.) } \\
\text { Hot pellet diameter, cm (in.) } \\
\text { Active fuel length, cm (in.) } \\
\text { Effective fuel temperature, K } \\
\text { Clad temperature, K } \\
\text { Clad material }\end{array}$ & $\begin{array}{l}\mathrm{UO}_{2} \\
10.13^{d} \\
1.956(0.770) \\
1.412(0.556) \\
1.260(0.496) \\
1.260(0.496) \\
146.67(57.744) \\
840^{e} \\
620^{e} \\
\text { Zircaloy-2 }\end{array}$ \\
\hline
\end{tabular}

${ }^{a}$ Not available in the literature. Data were assumed to be similar to data for Gundremmingen BWR.

${ }^{b}$ Calculated from other values listed in this table.

${ }^{c}$ Not available in the literature. Assumed the data.

${ }^{d}$ Assumed $1 \%$ pellet volume dishing and hot pellet diameter.

${ }^{e}$ Fuel and clad temperatures were not available in the literature. Temperatures given in generic BWR data from ref. 19 were applied.

Sources: Refs. 11 and 19. 


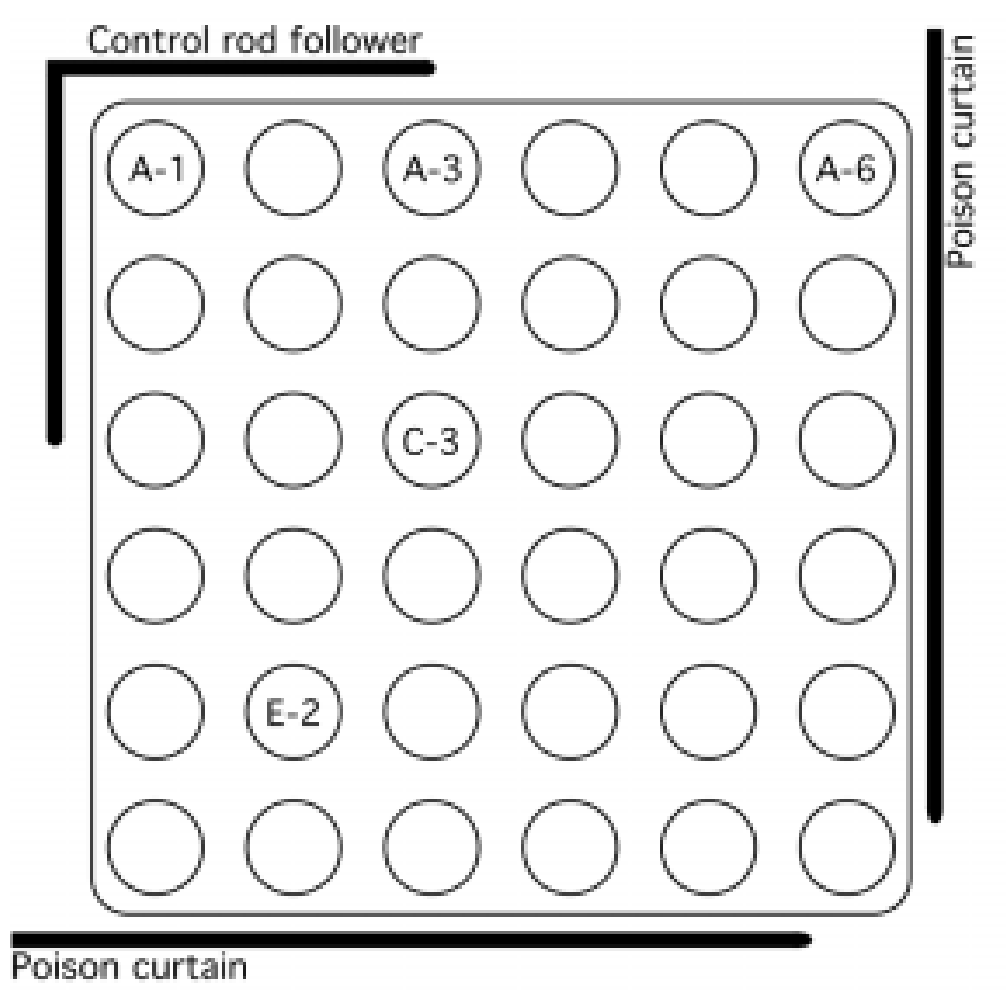

Fig. 5. Locations of fuel rods analyzed in Assembly A-20 of JPDR. 
The initial uranium isotopic composition of the fuel in Assemblies A-14, A-18, and A-20 are listed in Table 11. The isotopic contents were specified in at. $\%$ and converted to wt $\%$ for model input.

Table 11. Initial uranium composition ${ }^{a}$ of JPDR fuel samples

\begin{tabular}{c|c|c}
\hline & \multicolumn{2}{|c}{ Assemblies A-14, A-18, and A-20 } \\
\hline Uranium isotope & At. \% & Wt \% \\
\hline${ }^{235} \mathrm{U}$ & 2.629 & 2.5966 \\
${ }^{234} \mathrm{U}$ & 0.0156 & 0.0153 \\
${ }^{236} \mathrm{U}$ & 0.0162 & 0.0161 \\
${ }^{238} \mathrm{U}$ & 97.339 & 97.372 \\
\hline
\end{tabular}

${ }^{a}$ Data were reported ${ }^{11}$ in at. \% for each isotope. Data were converted to wt \% for required SAS2H input units.

The JPDR was an exceptionally small reactor. Both the equivalent core diameter and the core height of the JPDR are less than one-half the corresponding dimensions of the other two BWRs. The significance of the reactor core size was investigated by a set of trial cases: one case applied a buckling correction in the transport calculation, reducing $\mathrm{k}_{\mathrm{eff}}$ to approximately unity; the other case was tried without the buckling option, but with adequate boron content in the channel moderator to decrease the $\mathrm{k}_{\text {eff }}$ to unity (simulating control rods). Significant differences were noted between concentrations of similar isotopes for some of the nuclide results between the two cases. The analyzed assemblies were located either midway between the core center and the core edge or adjacent to the core edge. Also, documentation indicates that control rods in the vicinity of these assemblies had been fully withdrawn. Thus, it was decided to use the buckling option rather than adding boron to the channel moderator. The detailed model input, which applies the core dimensions taken from Table 10, is listed in Appendix D.

Rather than reporting an estimated burnup for each sample, JPDR fuel depletion was reported in terms of the percent of atoms fissioned (derived from ${ }^{148} \mathrm{Nd}$ concentrations). For this work, the fission fraction was converted to a burnup by assuming an energy release rate of $200 \mathrm{MeV} /$ fission. 
Both the fission fraction and calculated burnup are listed in Table 12. Average specific powers for each sample were calculated from the sample burnup and the total uptime.

Table 12. Operating data for JPDR fuel samples from Assemblies A-14, A-18, and A-20 and total assembly data

\begin{tabular}{c|c|c|c|c|c|c}
\hline $\begin{array}{c}\text { Assembly } \\
\text { ID }\end{array}$ & $\begin{array}{c}\text { Pin } \\
\text { No. }\end{array}$ & $\begin{array}{c}\text { Sample } \\
\text { node No. }\end{array}$ & $\begin{array}{c}\text { At. \% } \\
\text { fissions }\end{array}$ & $\begin{array}{c}\text { Burnup, } \\
\text { GWd/MTU }\end{array}$ & $\begin{array}{c}\text { Total } \\
\text { uptime, d }\end{array}$ & $\begin{array}{c}\text { Power, } \\
\text { MW/MTU }\end{array}$ \\
\hline A-14 & - & 2 & 0.352 & 3.0032 & 577.31 & 5.7217 \\
A-14 & - & 9 & 0.430 & 4.0351 & 577.31 & 6.9895 \\
A-18 & - & 2 & 0.289 & 2.7120 & 577.31 & 4.6976 \\
A-18 & - & 6 & 0.453 & 4.2510 & 577.31 & 7.3634 \\
A-20 & A1 & 3 & 0.747 & 7.0098 & 577.31 & 12.1423 \\
A-20 & A3 & 10 & 0.655 & 6.1465 & 577.31 & 10.6468 \\
A-20 & A6 & 3 & 0.741 & 6.9535 & 577.31 & 12.0447 \\
A-20 & A6 & 9 & 0.694 & 6.5125 & 577.31 & 11.2808 \\
A-20 & C3 & 1 & 0.282 & 2.6463 & 577.31 & 4.5838 \\
A-20 & C3 & 3 & 0.542 & 5.0861 & 577.31 & 8.8100 \\
A-20 & C3 & 5 & 0.648 & 6.0808 & 577.31 & 10.5330 \\
A-20 & C3 & 8 & 0.644 & 6.0433 & 577.31 & 10.4680 \\
A-20 & C3 & 10 & 0.539 & 5.0580 & 577.31 & 8.7613 \\
A-20 & C3 & 12 & 0.230 & 2.1583 & 577.31 & 3.7386 \\
A-20 & E2 & 3 & 0.597 & 5.6022 & 577.31 & 9.7041 \\
A-20 & E2 & 10 & 0.573 & 5.3770 & 577.31 & 9.3139 \\
A-14 & - & - & - & 5.570 & 577.31 & 9.6482 \\
A-18 & - & - & - & 5.015 & 577.31 & 8.6868 \\
A-20 & - & - & - & 3.707 & 577.31 & 6.4212 \\
\hline Rep07
\end{tabular}

${ }^{a}$ Reported as part of radiochemical analyses data (derived by applying the ${ }^{148} \mathrm{Nd}$ burnup method).

${ }^{b}$ Applied the factor 9.384 times the at. \% fissions to convert to burnup as GWd/MTU, assuming $200 \mathrm{MeV} /$ fission (the energy/fission computed by the ORIGEN-S code).

The JPDR was operated at low specific powers and burnups relative to typical commercial BWRs. In addition, JPDR was not a commercial reactor; and is not representative of commercial fuel either in terms of operation or assembly design. These data are considered valuable, however, because they characterize the relatively low burnup and high leakage of fuel located near the ends of typical spent fuel and one of the few sources of BWR data. The operating history of the analyzed assemblies consisted of 38 exposure periods, having an average length of about 2 weeks, and followed by an average downtime of about 6 weeks. This type of exposure history is 
unconventional and considerably different from typical exposure histories in commercial BWRs. Although minor variations within operating histories in a reactor fuel cycle are usually ignored in depletion calculations, the short operational periods and relatively long downtimes between power operations for JPDR warranted further study. Based on the exposure history of the Node 2 sample of JDPR assembly A-14, a SAS2H model was developed in which the numerous uptimes and downtimes were represented, assuming four exposure periods and four intervening downtimes, as given in Table 13, in which actual exposure and downtimes were consistent with actual operation. These values were compared with an ORIGEN-S model developed based on a series of 40 exposure periods and 39 downtimes (no downtime preceded the first exposure period); this assumed power history is given in Table 14.

Table 13. Example of power history applied in SAS2H depletion model of Assembly A-14, node 2

\begin{tabular}{c|c|c|c}
\hline $\begin{array}{c}\text { Exposure period } \\
\text { or SAS2H cycle }\end{array}$ & $\begin{array}{c}\text { Power } \\
\text { (MW/MTU) }\end{array}$ & $\begin{array}{c}\text { Uptime } \\
(\mathrm{d})\end{array}$ & $\begin{array}{c}\text { Downtime } \\
\text { (d) }\end{array}$ \\
\hline 1 & 5.7217 & 144.33 & 534.7 \\
2 & 5.7217 & 144.33 & 534.7 \\
3 & 5.7217 & 144.33 & 534.7 \\
4 & 5.7217 & 144.33 & 0 \\
Totals & & 577.33 & 1604.1 \\
\hline
\end{tabular}

Note that in general it can be difficult to model a large number of exposure periods using $\mathrm{SAS} 2 \mathrm{H}$, because this sequence creates a burnup-dependent cross-section library for each exposure step. The size of these libraries, combined with the number required, can present filesystem (disk space) problems on most computers. In the confirmatory ORIGEN-S calculations mentioned above, burnup-dependent cross-section libraries created by SAS2H for each of the four SAS2H exposure steps were used by ORIGEN-S (as indicated in the first column of Table 14. Although isotopic predictions can be sensitive to relative up- and downtimes, the cross sections used to generate fluxes for ORIGEN-S are far less sensitive to burnup effects. Thus the use of four SAS2H-prepared cross-section libraries in a tandem with 40 exposure periods in an ORIGEN-S is considered to be a close approximation. 
Table 14. Exposure uptimes and downtimes of power history in ORIGEN-S depletion model

\begin{tabular}{c|c|c|c|c|c|c}
\hline $\begin{array}{c}\text { SAS2H } \\
\text { library } \\
\text { No. }\end{array}$ & $\begin{array}{c}\text { Interval } \\
\text { uptime, } \\
\text { (d) }\end{array}$ & $\begin{array}{c}\text { No. of } \\
\text { uptime } \\
\text { intervals }\end{array}$ & $\begin{array}{c}\text { Uptimes } \\
\text { per library } \\
\text { (d) }\end{array}$ & $\begin{array}{c}\text { Interval } \\
\text { downtime } \\
(\mathrm{d})\end{array}$ & $\begin{array}{c}\text { No. of } \\
\text { downtime } \\
\text { intervals }\end{array}$ & $\begin{array}{c}\text { Downtime } \\
\text { per library } \\
\text { (d) }\end{array}$ \\
\hline 1 & 14.433 & 10 & 144.33 & 41.131 & 9 & 370.179 \\
2 & 14.433 & 10 & 144.33 & 41.131 & 10 & 411.310 \\
3 & 14.433 & 10 & 144.33 & 41.131 & 10 & 411.310 \\
4 & 14.433 & 10 & 144.33 & 41.131 & 10 & 411.310 \\
& & & 577.32 & & & 1604.109 \\
\hline
\end{tabular}

A comparison of results for the detailed ORIGEN-S model and the more coarse SAS2H model showed significant disagreement between results for short-lived (less than 1 year) nuclides. This disagreement would be expected, since such nuclides are known to be sensitive to operating history. However, the results also showed a good agreement in concentration of long-lived (greater than 1 year) or stable nuclides, which are only loosely coupled to operating history effects. ${ }_{\text {This }}$ study indicated that the use of the four-cycle SAS2H depletion approximation was adequate for applications that require more than 1 year of cooling (e.g., transportation and disposal). Hence this depletion model was applied for all JPDR fuel samples.

Also in departure from commercial reactor design, the JPDR fuel assemblies contained no water holes or poison rods. In other words, all 36 positions in the $6 \times 6$ lattice were occupied by fuel rods. The Path B (full-assembly) portion of SAS2H models includes a nonfuel material (e.g., water hole or absorber rod) in the center of the 1-D radial model, representing interstitial nonfuel rods in an assembly. Placement of the homogenized pin-cell materials (mixture 500 from Path A) in the central region of the Path B model results in incorrect fuel depletion. Hence for the Path B SAS2H JPDR models, a very small central zone of ${ }^{14} \mathrm{~N}$ was created (zone 1), which was surrounded by the homogenized Path A mixture. The neutronic effect of this approximation is insignificant. Beyond this approximation, however, the methods employed in the development of the SAS2H models for JPDR fuel assemblies are identical to other SAS2H models. Assembly lattice, channel tube, and outer moderator volumes were conserved in developing equivalent radii for the 1-D Path B model. Zone 2 represents the smeared contents of the $6 \times 6$ fuel lattice. Zone 3 in the model represents low- 
density moderator outside the simple lattice but interior to the channel tube. Zones 4 and 5 represent the channel tube and exterior moderator, respectively. The radii for each zone are given in Table 15. Full SAS2H input listings are provided in Appendix D for all JPDR fuel samples.

Table 15. Effective geometry for JPDR assembly model

\begin{tabular}{c|l|c}
\hline Radial zone & \multicolumn{1}{|c|}{ Material } & $\begin{array}{c}\text { Radius } \\
(\mathrm{cm})\end{array}$ \\
\hline 1 & ${ }^{14} \mathrm{~N}$ & 0.0010 \\
2 & Homogenized fuel, clad and moderator (from Path A) & 6.6213 \\
3 & Low-density moderator & 6.8521 \\
4 & Channel tube & 7.0213 \\
5 & Moderator outside of channel tube & 7.4812 \\
\hline
\end{tabular}




\section{PREDICTED AND MEASURED ISOTOPIC COMPOSITIONS}

Comparisons of spent PWR fuel isotopic compositions predicted by SCALE-4.3 calculations with those measured by radiochemical assay analyses are provided in this section. Percentage differences between the computed and measured values for isotopes selected for assay analysis are given for each sample. Also included in this section are average percentage differences for each of the three reactors in this validation analysis and for the entire set of analyses included in this study. Additional comparisons listing measurements, computed predictions, and percentage differences for each isotope of each sample are included in Appendixes E, F, and $\mathrm{G}$ for Cooper, Gundremmingen, and JPDR, respectively. Some of the measured data were converted from the reported units to units of either milligrams/gram (mg/g) $\mathrm{UO}_{2}$ (stable/long-lived nuclides) or curies/gram $(\mathrm{Ci} / \mathrm{g}) \quad \mathrm{UO}_{2}$ (shorter-lived nuclides).

\subsection{COOPER BWR ISOTOPIC RESULTS}

Radiochemical isotopic analyses of the Cooper BWR spent fuel were conducted by the MCC at PNL. Isotopic composition measurements of the Cooper spent fuel from two different fuel pins are listed in Tables 16 and 17. The axial locations and burnups of the six fuel specimens analyzed, included in the tables, are two of the major characteristics describing the samples.

The percentage differences between measured and calculated isotopic compositions of each fuel specimen are given in Table 18. This table also provides the average percentage difference of the Cooper BWR samples for each isotope. Percentage differences by sample are also plotted in Fig. 6. 
Table 16. Measured irradiation composition, in $\mathrm{g} / \mathrm{g} \mathrm{UO} \mathrm{U}_{2}$, of Cooper BWR fuel

\begin{tabular}{|c|c|c|c|c|c|c|}
\hline \multirow[b]{2}{*}{ Nuclide } & \multicolumn{6}{|c|}{$\begin{array}{l}\text { Pin ID and axial location, } \mathrm{cm} \text { from bottom of fuel } \\
\left.\text { (Burnup, }{ }^{a} \mathrm{GWd} / \mathrm{MTU}\right)\end{array}$} \\
\hline & $\begin{array}{l}\text { Pin } \mathrm{B}^{b} \\
351.7 \mathrm{~cm} \\
(18.96)\end{array}$ & $\begin{array}{l}\text { Pin } \mathrm{B}^{b} \\
186.9 \mathrm{~cm} \\
(30.07)\end{array}$ & $\begin{array}{l}\text { Pin } \mathrm{B}^{b} \\
131.0 \mathrm{~cm} \\
(33.94)\end{array}$ & $\begin{array}{l}\text { Pin } \mathrm{C}^{c} \\
350.1 \mathrm{~cm} \\
(17.84)\end{array}$ & $\begin{array}{l}\text { Pin } \mathrm{C}^{c} \\
290.7 \mathrm{~cm} \\
(29.23)\end{array}$ & $\begin{array}{l}\text { Pin } \mathrm{C}^{c} \\
114.7 \mathrm{~cm} \\
(31.04)\end{array}$ \\
\hline${ }^{234} \mathrm{U}$ & $1.7 \times 10^{-4}$ & $1.35 \times 10^{-4}$ & $1.44 \times 10^{-4}$ & $1.74 \times 10^{-4}$ & $1.46 \times 10^{-4}$ & $1.54 \times 10^{-4}$ \\
\hline${ }^{235} \mathrm{U}$ & $1.191 \times 10^{-2}$ & $5.34 \times 10^{-3}$ & $4.83 \times 10^{-3}$ & $1.30 \times 10^{-2}$ & $7.76 \times 10^{-3}$ & $6.28 \times 10^{-3}$ \\
\hline${ }^{236} \mathrm{U}$ & $2.63 \times 10^{-3}$ & $3.53 \times 10^{-3}$ & $3.62 \times 10^{-3}$ & $2.48 \times 10^{-3}$ & $3.36 \times 10^{-3}$ & $3.48 \times 10^{-3}$ \\
\hline${ }^{238} \mathrm{U}$ & $8.437 \times 10^{-1}$ & $8.346 \times 10^{-1}$ & $8.391 \times 10^{-1}$ & $8.545 \times 10^{-1}$ & $8.490 \times 10^{-1}$ & $8.455 \times 10^{-1}$ \\
\hline${ }^{238} \mathrm{Pu}$ & $5.35 \times 10^{-5}$ & $1.743 \times 10^{-4}$ & $1.706 \times 10^{-4}$ & $5.21 \times 10^{-5}$ & $1.64 \times 10^{-4}$ & $1.389 \times 10^{-4}$ \\
\hline${ }^{239} \mathrm{Pu}$ & $3.738 \times 10^{-3}$ & $3.579 \times 10^{-3}$ & $3.336 \times 10^{-3}$ & $4.056 \times 10^{-3}$ & $4.526 \times 10^{-3}$ & $3.668 \times 10^{-3}$ \\
\hline${ }^{240} \mathrm{Pu}$ & $1.220 \times 10^{-3}$ & $2.216 \times 10^{-3}$ & $2.190 \times 10^{-3}$ & $1.184 \times 10^{-3}$ & $2.164 \times 10^{-3}$ & $2.082 \times 10^{-3}$ \\
\hline${ }^{241} \mathrm{Pu}$ & $3.403 \times 10^{-4}$ & $6.390 \times 10^{-4}$ & $6.201 \times 10^{-4}$ & $3.415 \times 10^{-4}$ & $6.649 \times 10^{-4}$ & $6.139 \times 10^{-4}$ \\
\hline${ }^{242} \mathrm{Pu}$ & $9.892 \times 10^{-7}$ & $4.407 \times 10^{-4}$ & $4.737 \times 10^{-4}$ & $8.742 \times 10^{-5}$ & $3.247 \times 10^{-4}$ & $3.823 \times 10^{-4}$ \\
\hline
\end{tabular}

${ }^{a}$ Based on measured ${ }^{148} \mathrm{Nd}$ concentration.

${ }^{b}$ Radiochemical analyses conducted at a cooling time of 5.35 years, or 1954 days.

${ }^{c}$ Radiochemical analyses conducted at a cooling time of 5.28 years, or 1929 days.

Source: Ref. 10.

Table 17. Measured irradiation composition, in $\mathrm{Ci} / \mathrm{g} \mathrm{\textrm {UO } _ { 2 }}$, of Cooper BWR fuel

\begin{tabular}{l|l|l|l|l|l|l}
\hline \multirow{2}{*}{} & \multicolumn{7}{|c}{ Pin ID and axial location, cm from bottom of fuel } \\
& \multicolumn{7}{c}{ Burnup, GWd/MTU) } \\
\cline { 2 - 7 } & Pin B3 & Pin B3 & Pin B3 & Pin C3 & Pin C3 & Pin C3 \\
& $351.7 \mathrm{~cm}$ & $186.9 \mathrm{~cm}$ & $131.0 \mathrm{~cm}$ & $350.1 \mathrm{~cm}$ & $290.7 \mathrm{~cm}$ & $114.7 \mathrm{~cm}$ \\
Nuclide & $(18.96)$ & $(30.07)$ & $(33.94)$ & $(17.84)$ & $(29.23)$ & $(31.04)$ \\
\hline${ }^{237} \mathrm{~Np}$ & $1.11 \times 10^{-7}$ & $2.54 \times 10^{-7}$ & $2.46 \times 10^{-7}$ & $1.09 \times 10^{-7}$ & $2.35 \times 10^{-7}$ & $2.36 \times 10^{-7}$ \\
${ }^{241} \mathrm{Am}$ & $5.18 \times 10^{-4}$ & $8.78 \times 10^{-4}$ & $8.38 \times 10^{-4}$ & $5.23 \times 10^{-4}$ & $9.46 \times 10^{-4}$ & $8.69 \times 10^{-4}$ \\
${ }^{243} \mathrm{Cm}+{ }^{244} \mathrm{Cm}$ & $1.10 \times 10^{-4}$ & $1.45 \times 10^{-3}$ & $1.50 \times 10^{-3}$ & $1.14 \times 10^{-4}$ & $1.10 \times 10^{-3}$ & $1.07 \times 10^{-3}$ \\
${ }^{79} \mathrm{Se}$ & $2.77 \times 10^{-8}$ & $4.59 \times 10^{-8}$ & $4.96 \times 10^{-8}$ & $2.70 \times 10^{-8}$ & $4.26 \times 10^{-8}$ & $4.50 \times 10^{-8}$ \\
${ }^{90} \mathrm{Sr}$ & $3.21 \times 10^{-2}$ & $4.86 \times 10^{-2}$ & $5.09 \times 10^{-2}$ & $2.92 \times 10^{-2}$ & $4.38 \times 10^{-2}$ & $4.82 \times 10^{-2}$ \\
${ }^{99} \mathrm{Tc}$ & $6.26 \times 10^{-6}$ & $1.03 \times 10^{-5}$ & $1.06 \times 10^{-5}$ & $6.17 \times 10^{-6}$ & $9.86 \times 10^{-6}$ & $1.00 \times 10^{-5}$ \\
${ }^{126} \mathrm{Sn}$ & $7.79 \times 10^{-8}$ & $1.52 \times 10^{-7}$ & $1.60 \times 10^{-7}$ & $7.34 \times 10^{-8}$ & $1.41 \times 10^{-7}$ & $1.46 \times 10^{-7}$ \\
${ }^{135} \mathrm{Cs}$ & $3.74 \times 10^{-7}$ & $4.46 \times 10^{-7}$ & $4.29 \times 10^{-7}$ & $3.83 \times 10^{-7}$ & $5.23 \times 10^{-7}$ & $4.31 \times 10^{-7}$ \\
${ }^{137} \mathrm{Cs}$ & $4.27 \times 10^{-2}$ & $7.48 \times 10^{-2}$ & $7.70 \times 10^{-2}$ & $4.05 \times 10^{-2}$ & $7.25 \times 10^{-2}$ & $6.85 \times 10^{-2}$ \\
\hline
\end{tabular}

Source: Ref. 10. 
Table 18. Percentage difference ${ }^{a}$ between measured and computed ${ }^{b}$ nuclide compositions for Cooper BWR samples and averages

from Assembly CZ346

\begin{tabular}{|c|c|c|c|c|c|c|c|c|}
\hline $\begin{array}{l}\text { Pin } \\
\text { Axial height, cm } \\
\text { Burnup, } \\
\text { GWd/MTU } \\
\text { Initial wt } \%{ }^{235} \mathrm{U}\end{array}$ & $\begin{array}{c}\text { B3 } \\
351.7 \\
18.96 \\
2.939\end{array}$ & $\begin{array}{r}\text { B3 } \\
186.9 \\
30.07 \\
2.939\end{array}$ & $\begin{array}{c}\text { B3 } \\
131.0 \\
33.94 \\
2.939\end{array}$ & $\begin{array}{r}\text { C3 } \\
350.1 \\
17.84 \\
2.939\end{array}$ & $\begin{array}{r}\text { C3 } \\
290.7 \\
29.23 \\
2.939\end{array}$ & $\begin{array}{r}\text { C3 } \\
114.7 \\
31.04 \\
2.939\end{array}$ & & \\
\hline Nuclide & & & & & & & Average & $\begin{array}{c}\text { Std. } \\
\text { Deviation }\end{array}$ \\
\hline${ }^{234} \mathrm{U}$ & -0.3 & 3.1 & -4.1 & -0.9 & -0.1 & -6.1 & -1.4 & 3.2 \\
\hline${ }^{235} \mathrm{U}$ & -1.3 & -0.1 & -2.6 & -4.9 & -9.5 & -11.7 & -5.0 & 4.7 \\
\hline${ }^{236} \mathrm{U}$ & -0.7 & -1.6 & -3.1 & 1.3 & -1.9 & -2.0 & -1.3 & 1.5 \\
\hline${ }^{238} \mathrm{U}$ & -0.1 & -0.1 & -0.5 & -1.2 & -1.5 & -1.1 & -0.7 & 0.6 \\
\hline${ }^{238} \mathrm{Pu}$ & -1.0 & -7.0 & -6.8 & -11.9 & -7.0 & -6.9 & -6.8 & 3.5 \\
\hline${ }^{239} \mathrm{Pu}$ & 6.3 & 8.8 & 7.7 & -3.9 & -6.9 & -4.3 & 1.3 & 7.0 \\
\hline${ }^{240} \mathrm{Pu}$ & 2.1 & -6.0 & -5.0 & -1.9 & -11.1 & -7.6 & -4.9 & 4.6 \\
\hline${ }^{241} \mathrm{Pu}$ & 17.1 & 7.5 & 5.9 & 7.4 & -1.1 & -2.6 & 5.7 & 7.1 \\
\hline${ }^{242} \mathrm{Pu}$ & 22.7 & 5.5 & 4.8 & 18.5 & 7.4 & 5.4 & 10.7 & 7.8 \\
\hline${ }^{237} \mathrm{~Np}$ & 17.3 & -4.2 & -3.2 & 10.1 & -5.6 & -10.8 & 0.6 & 10.7 \\
\hline${ }^{241} \mathrm{Am}$ & 28.4 & 20.3 & 18.9 & 16.5 & 8.9 & 5.1 & 16.3 & 8.4 \\
\hline${ }^{244} \mathrm{Cm}$ & 41.4 & 18.1 & 15.5 & 2.0 & 1.0 & 2.8 & 13.5 & 15.5 \\
\hline${ }^{79} \mathrm{Se}$ & 24.9 & 28.1 & 21.7 & 20.8 & 22.8 & 23.6 & 23.6 & 2.6 \\
\hline${ }^{90} \mathrm{Sr}$ & 5.9 & 10.2 & 8.2 & 10.8 & 10.4 & 7.7 & 8.9 & 1.9 \\
\hline${ }^{99} \mathrm{Tc}$ & 14.1 & 14.6 & 14.5 & 9.5 & 7.0 & 12.6 & 12.1 & 3.1 \\
\hline${ }^{126} \mathrm{Sn}$ & 206.1 & 218.4 & 210.0 & 200.2 & 195.3 & 200.9 & 205.2 & 8.2 \\
\hline${ }^{135} \mathrm{Cs}$ & 10.4 & 8.7 & 8.7 & 4.5 & -6.5 & 4.6 & 5.1 & 6.2 \\
\hline${ }^{137} \mathrm{Cs}$ & 3.6 & 3.3 & 3.1 & 3.0 & -5.7 & 6.2 & 2.3 & 4.1 \\
\hline
\end{tabular}

${ }^{a}($ Calculated/measured -1$) \times 100 \%$.

${ }^{b}$ Using SAS2H/ORIGEN-S analysis sequence and the 44-group cross-section library of SCALE-4.3. 

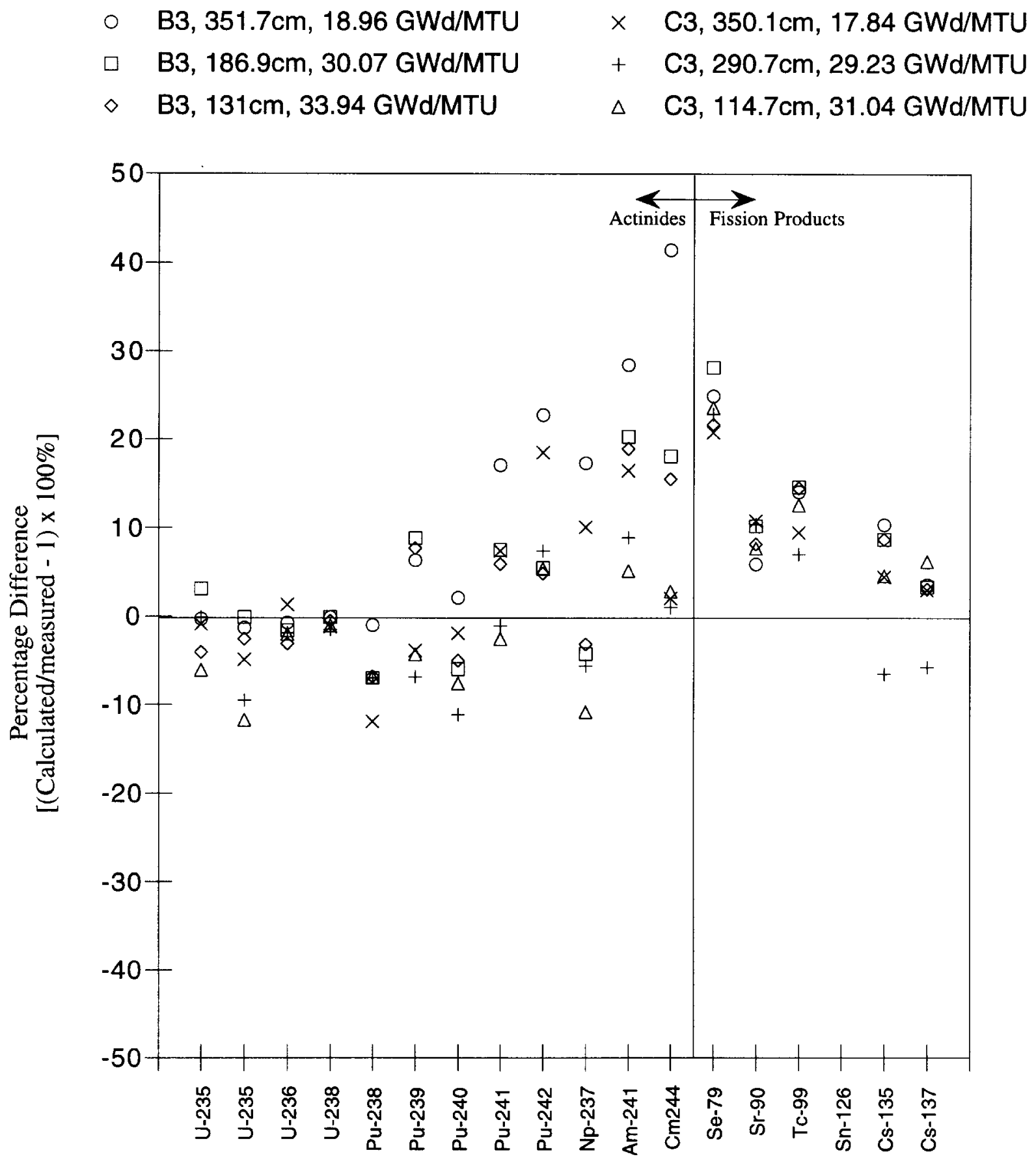

Fig. 6. Percentage differences between measured and calculated results for Cooper fuel samples. 


\subsection{GUNDREMMINGEN BWR ISOTOPIC RESULTS}

Radiochemical isotopic analyses of Gundremmingen BWR spent fuel were conducted by the Ispra and Karlsruhe facilities of EJRC. The spent fuel specimens taken from pin A1 of Assemblies B23 and C16 were analyzed at Ispra only; all other sample analyses were performed at both the Karlsruhe and the Ispra establishments. For twice-measured samples, the average of the two measurements was reported. Isotopic composition measurements from six different pins (from two fuel assemblies) are listed in Table 19. The compositions were reported in several types of units; each type of reported measurement is specified in the table. However, all data were converted to units of milligrams per initial gram of uranium or curies per initial gram of uranium (shown in Appendix F for consistency with previous validation studies. Axial locations and burnups characterizing the samples are listed with the same measurements in Table 19. The percentage differences between measured and SCALE-predicted isotopic compositions are presented in Table 20 and are plotted as a function of isotope in Fig. 7.

\subsection{JPDR ISOTOPIC RESULTS}

Radiochemical analyses of the JPDR spent BWR fuel were performed at JAERI. Isotopic composition measurements of 16 pellet samples from several fuel pins of three different fuel assemblies are listed in Tables 21 and 22. The compositions are given in several different units, as reported. All data were subsequently converted into units of milligram per gram of initial uranium (shown in Appendix G) for consistency with previous studies. Axial locations and burnups of the samples are listed with the associated measurements in the tables. The percentage differences between measured and predicted concentrations are listed in Table 23. Figure 8 illustrates these percentage differences for each sample as a function of a nuclide. 


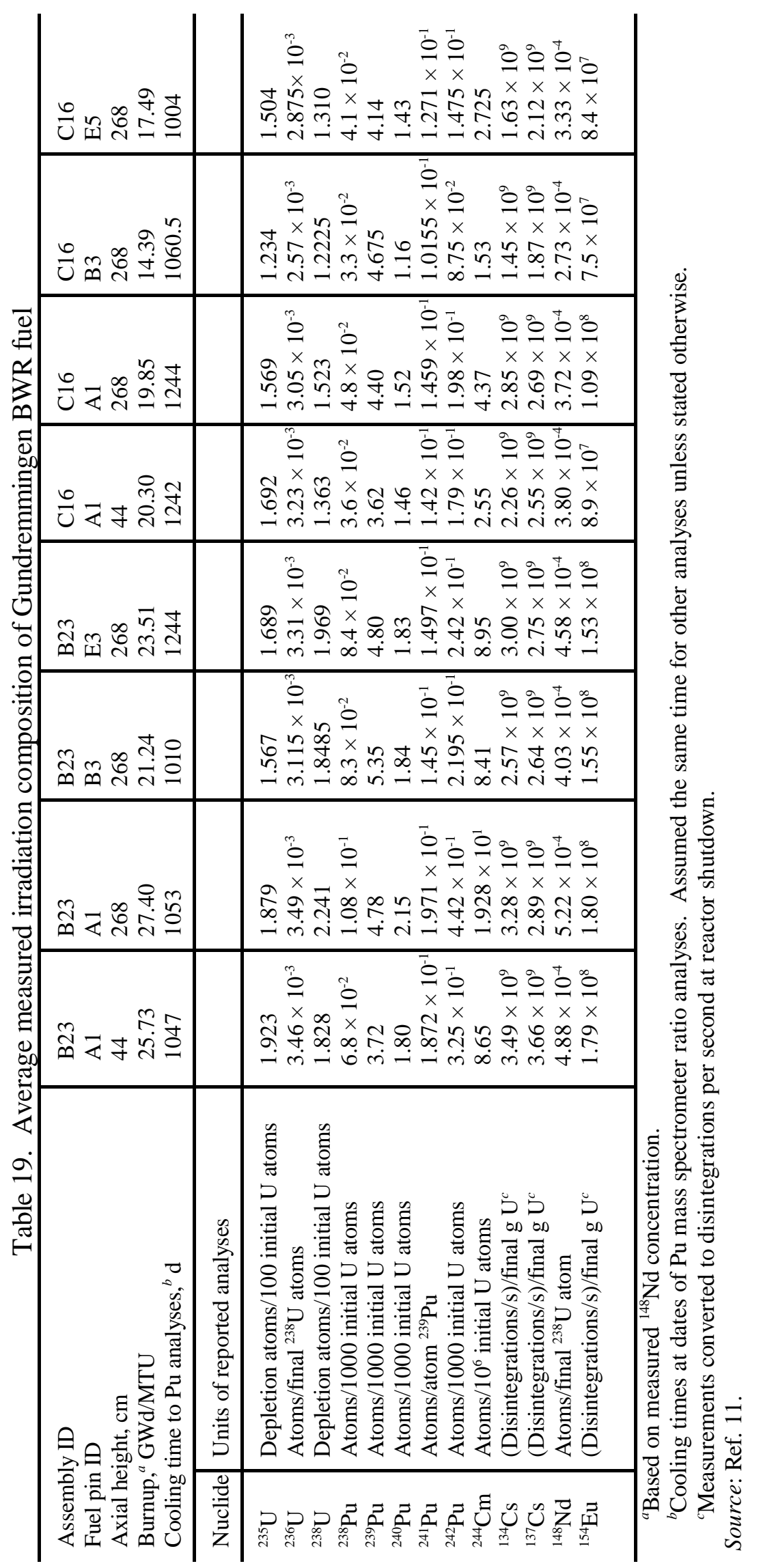




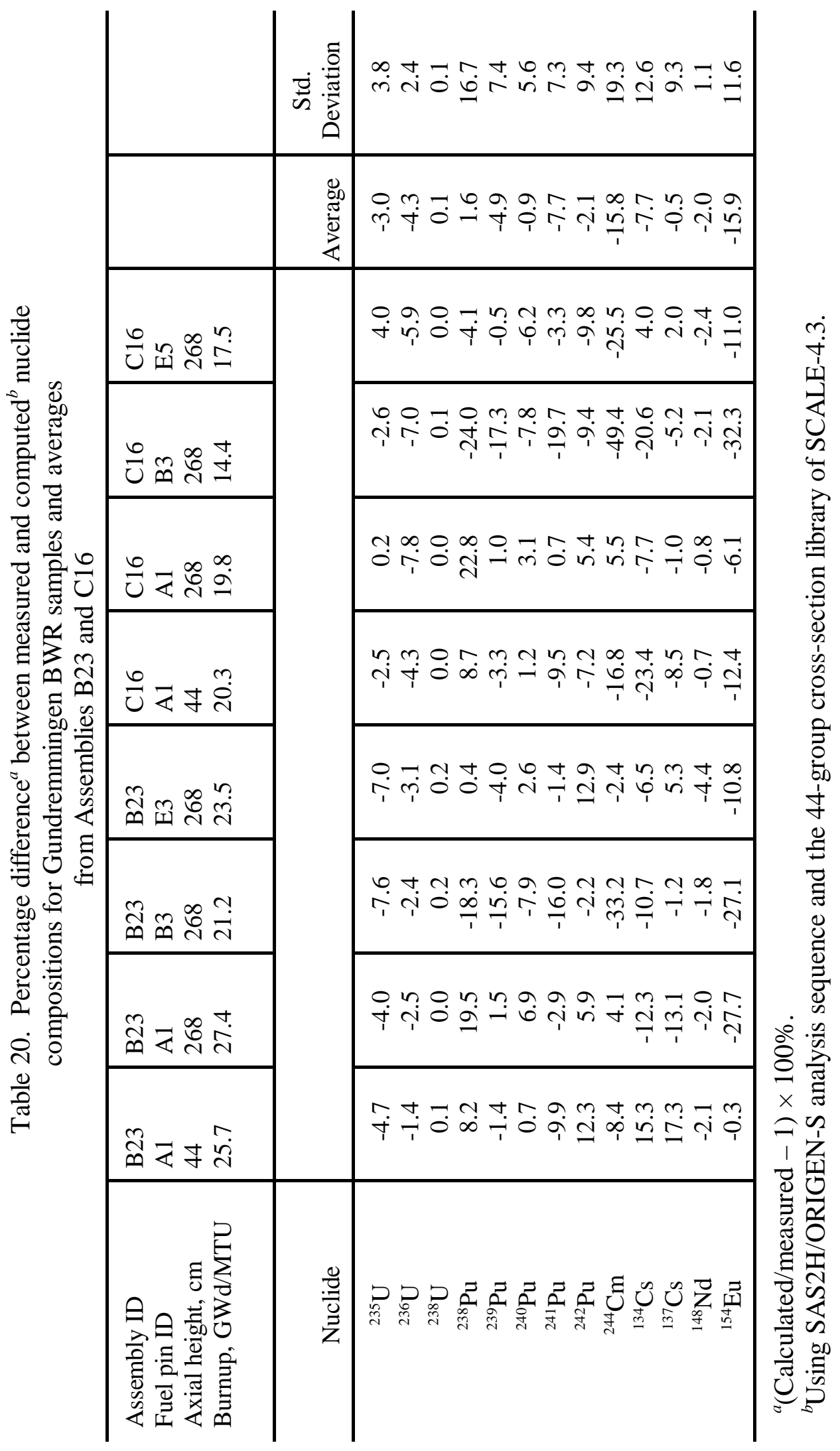


- B23/A1, 44cm, $25.7 \mathrm{GWd} / \mathrm{MTU}$

B23/A1, 268cm, $27.4 \mathrm{GWd} / \mathrm{MTU}$

$\diamond \quad \mathrm{B} 23 / \mathrm{B} 3,268 \mathrm{~cm}, 21.2 \mathrm{GWd} / \mathrm{MTU}$

$\times \quad B 23 / E 3,268 \mathrm{~cm}, 23.5 \mathrm{GWd} / \mathrm{MTU}$ $+\quad \mathrm{C} 16 / \mathrm{A} 1,44 \mathrm{~cm}, 20.3 \mathrm{GWd} / \mathrm{MTU}$

$\triangle \quad \mathrm{C} 16 / \mathrm{A} 1,268 \mathrm{~cm}, 19.8 \mathrm{GWd} / \mathrm{MTU}$

- $\mathrm{C} 16 / \mathrm{B} 3,268 \mathrm{~cm}, 14.4 \mathrm{GWd} / \mathrm{MTU}$

- $\mathrm{C} 16 / \mathrm{E} 5,268 \mathrm{~cm}, 17.5 \mathrm{GWd} / \mathrm{MTU}$

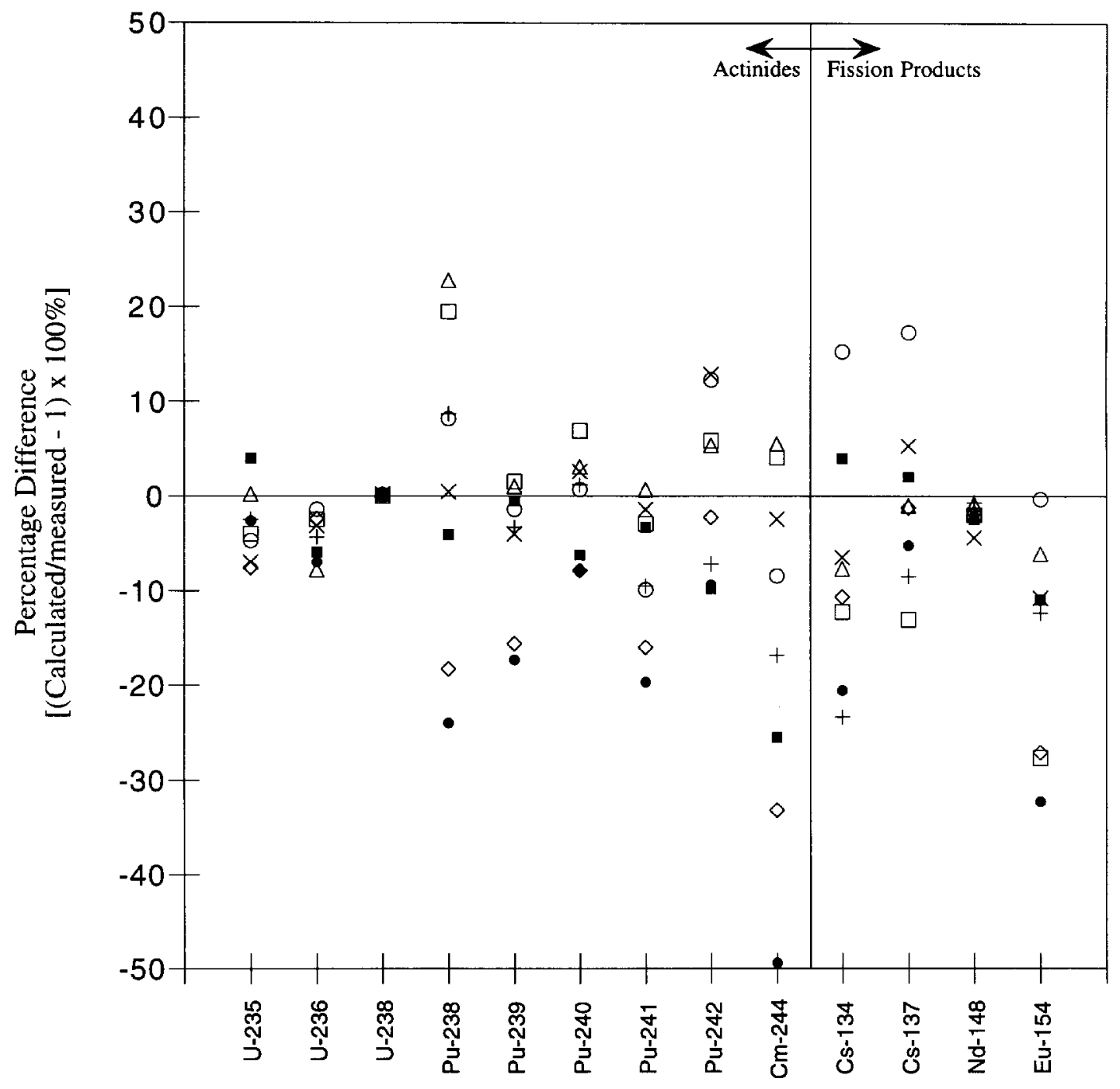

Fig. 7. Percentage differences between measured and calculated results for Gundremmingen fuel samples. 


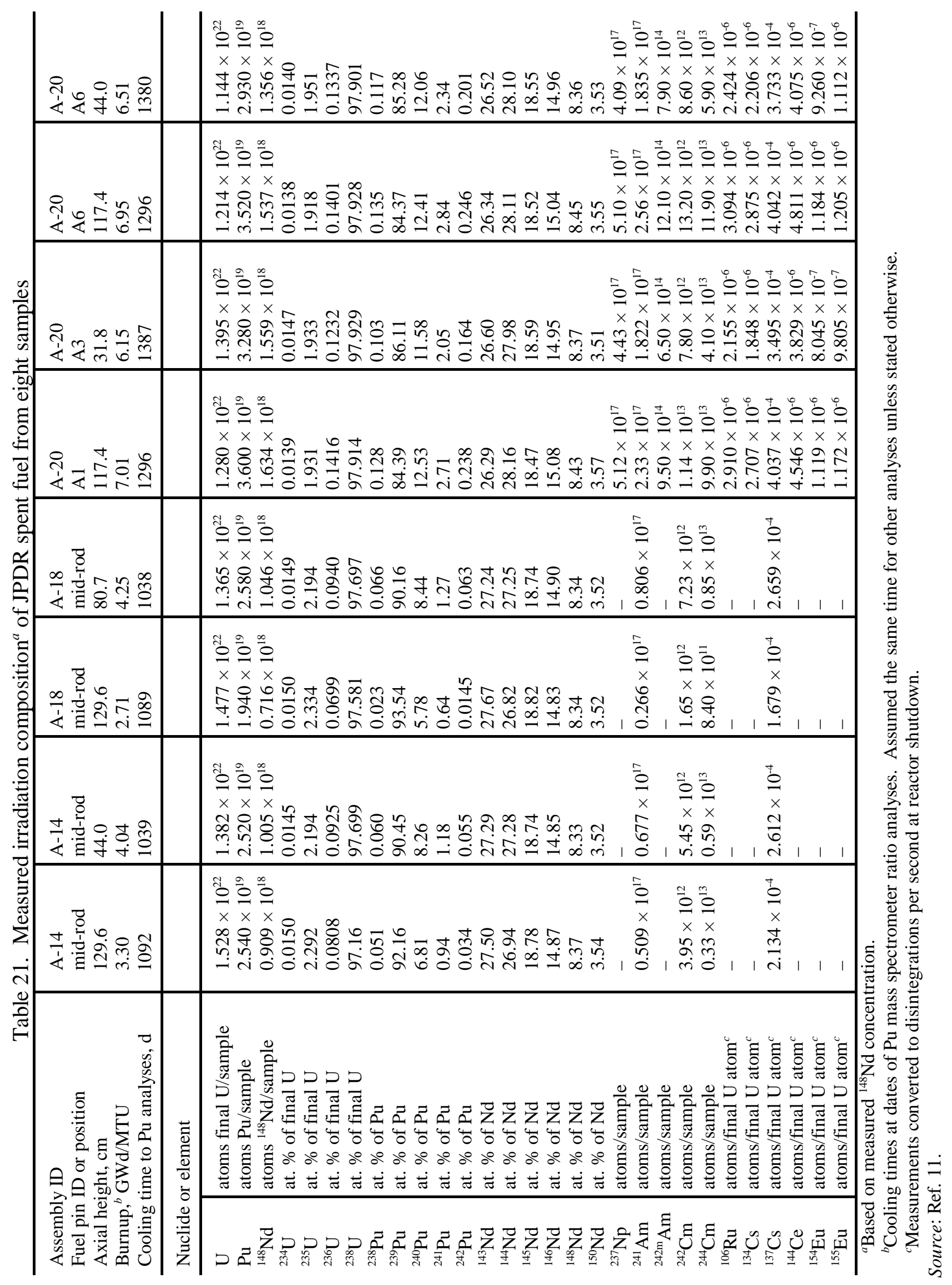




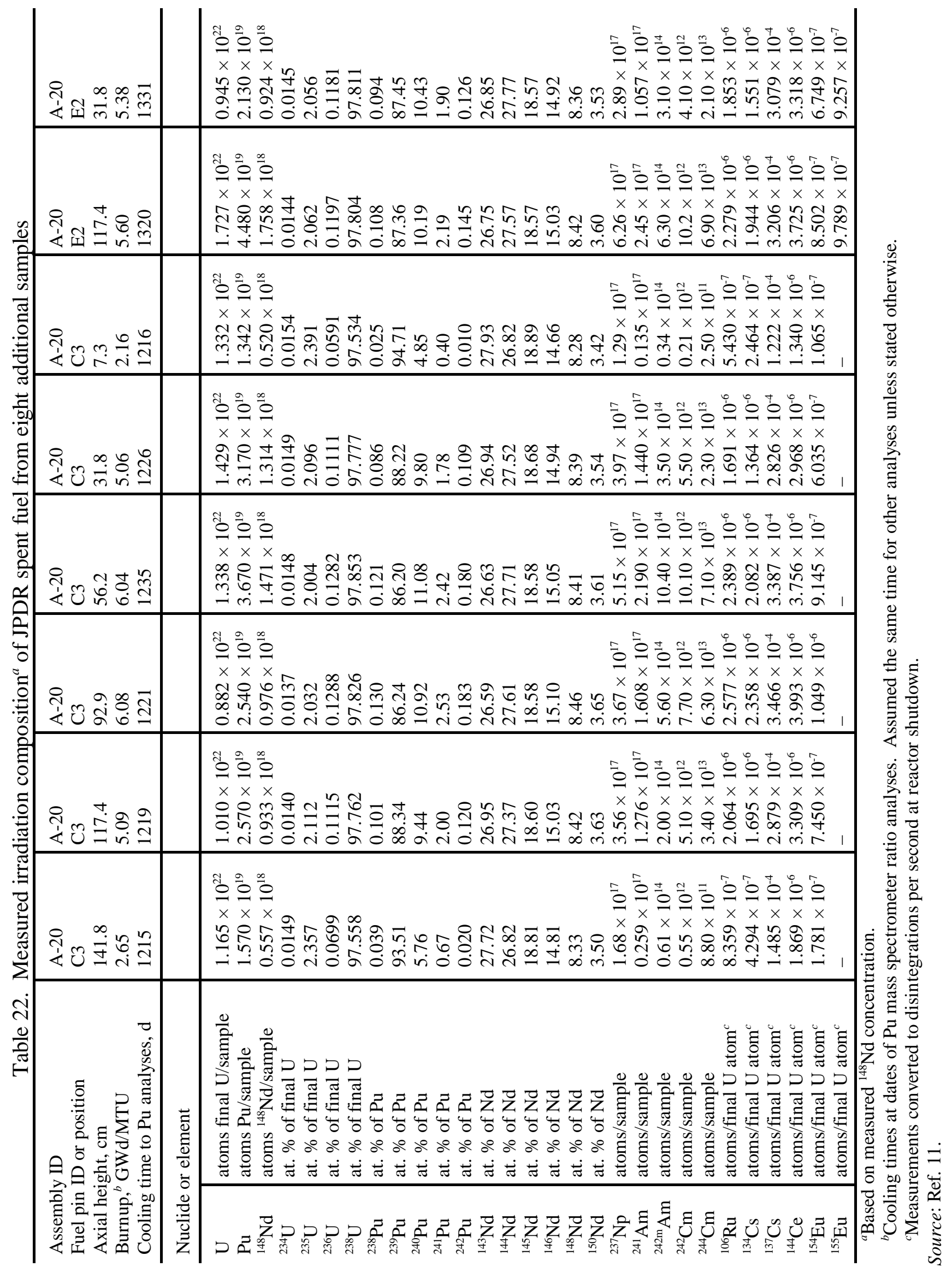




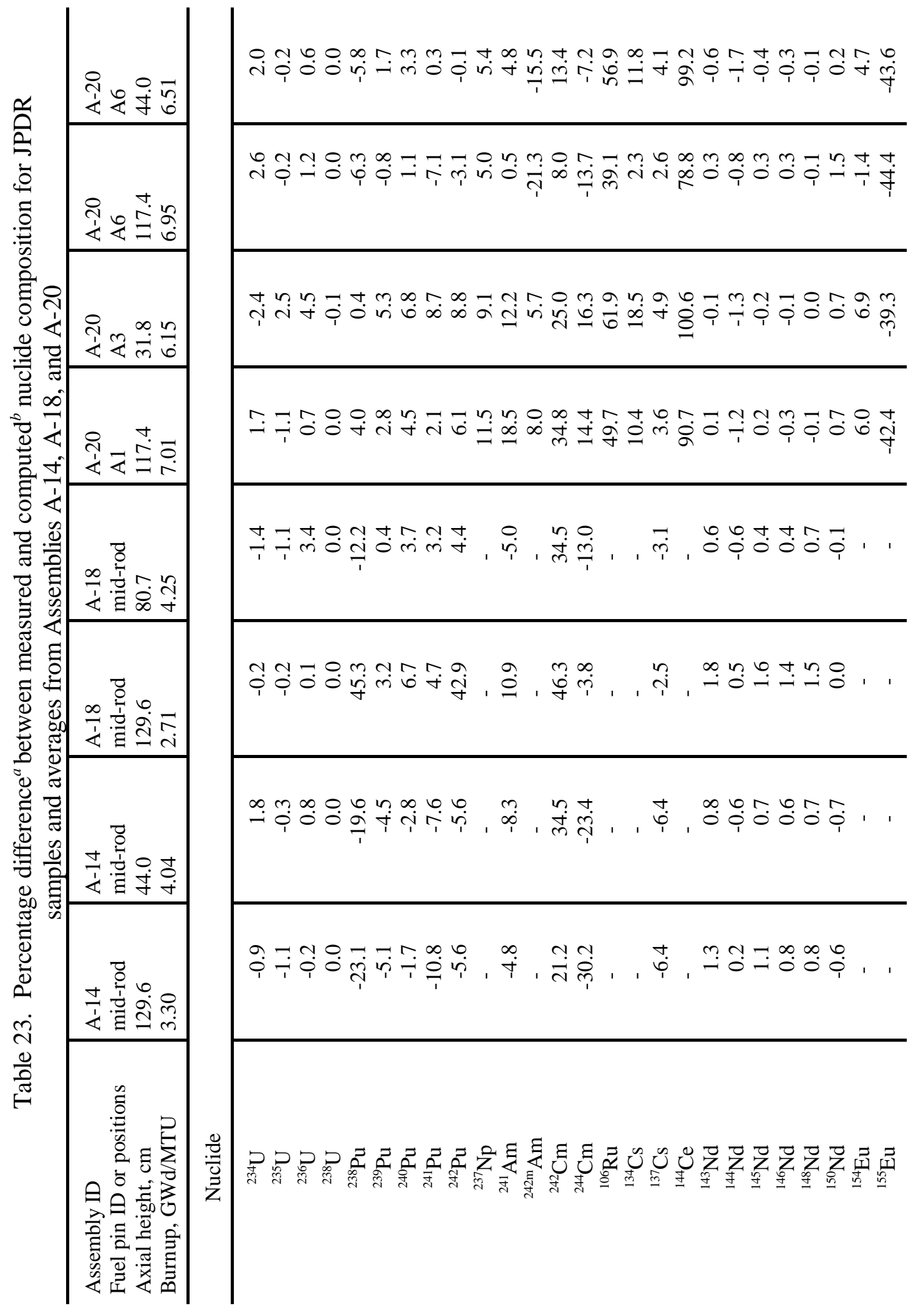




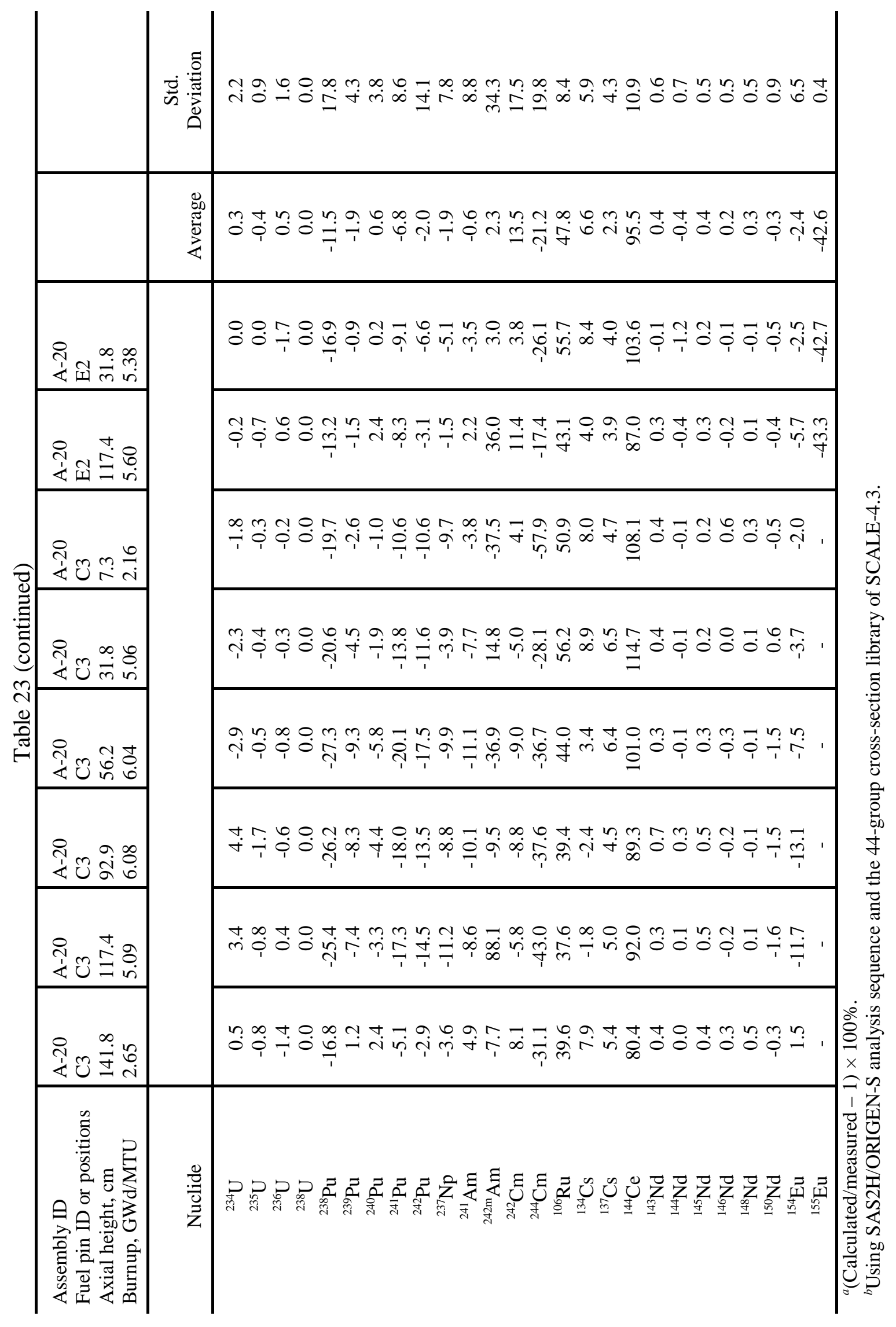


- A-14/mid, $129.6 \mathrm{~cm}, 3.30 \mathrm{GWd} / \mathrm{MTU}$

A-14/mid, $44.0 \mathrm{~cm}, 4.04 \mathrm{GWd} / \mathrm{MTU}$

$\diamond \quad$ A-18/mid, $129.6 \mathrm{~cm}, 2.71 \mathrm{GWd} / \mathrm{MTU}$

$\times$ A-18/mid, $80.7 \mathrm{~cm}, 4.25 \mathrm{GWd} / \mathrm{MTU}$

$+\quad \mathrm{A}-20 / \mathrm{A} 1,117.4 \mathrm{~cm}, 7.01 \mathrm{GWd} / \mathrm{MTU}$

$\triangle \quad \mathrm{A}-20 / \mathrm{A3}, 31.8 \mathrm{~cm}, 6.15 \mathrm{GWd} / \mathrm{MTU}$

- $\mathrm{A}-20 / \mathrm{A} 6,117.4 \mathrm{~cm}, 6.95 \mathrm{GWd} / \mathrm{MTU}$

- A-20/A6, $44.0 \mathrm{~cm}, 6.51 \mathrm{GWd} / \mathrm{MTU}$
- $\mathrm{A}-20 / \mathrm{C} 3,141.8 \mathrm{~cm}, 2.65 \mathrm{GWd} / \mathrm{MTU}$

- $\mathrm{A}-20 / \mathrm{C} 3,117.4 \mathrm{~cm}, 5.09 \mathrm{GWd} / \mathrm{MTU}$

- A-20/C3, $92.9 \mathrm{~cm}, 6.08 \mathrm{GWd} / \mathrm{MTU}$

$\rightarrow \mathrm{A}-20 / \mathrm{C} 3,56.2 \mathrm{~cm}, 6.04 \mathrm{GWd} / \mathrm{MTU}$

$\triangle \quad \mathrm{A}-20 / \mathrm{C} 3,31.8 \mathrm{~cm}, 5.06 \mathrm{GWd} / \mathrm{MTU}$

$\rightarrow \mathrm{A}-20 / \mathrm{C} 3,7.3 \mathrm{~cm}, 2.16 \mathrm{GWd} / \mathrm{MTU}$

A-20/E2, $117.4 \mathrm{~cm}, 5.60 \mathrm{GWd} / \mathrm{MTU}$

$\nabla \quad$ A-20/E2, $31.8 \mathrm{~cm}, 5.38 \mathrm{GWd} / \mathrm{MTU}$

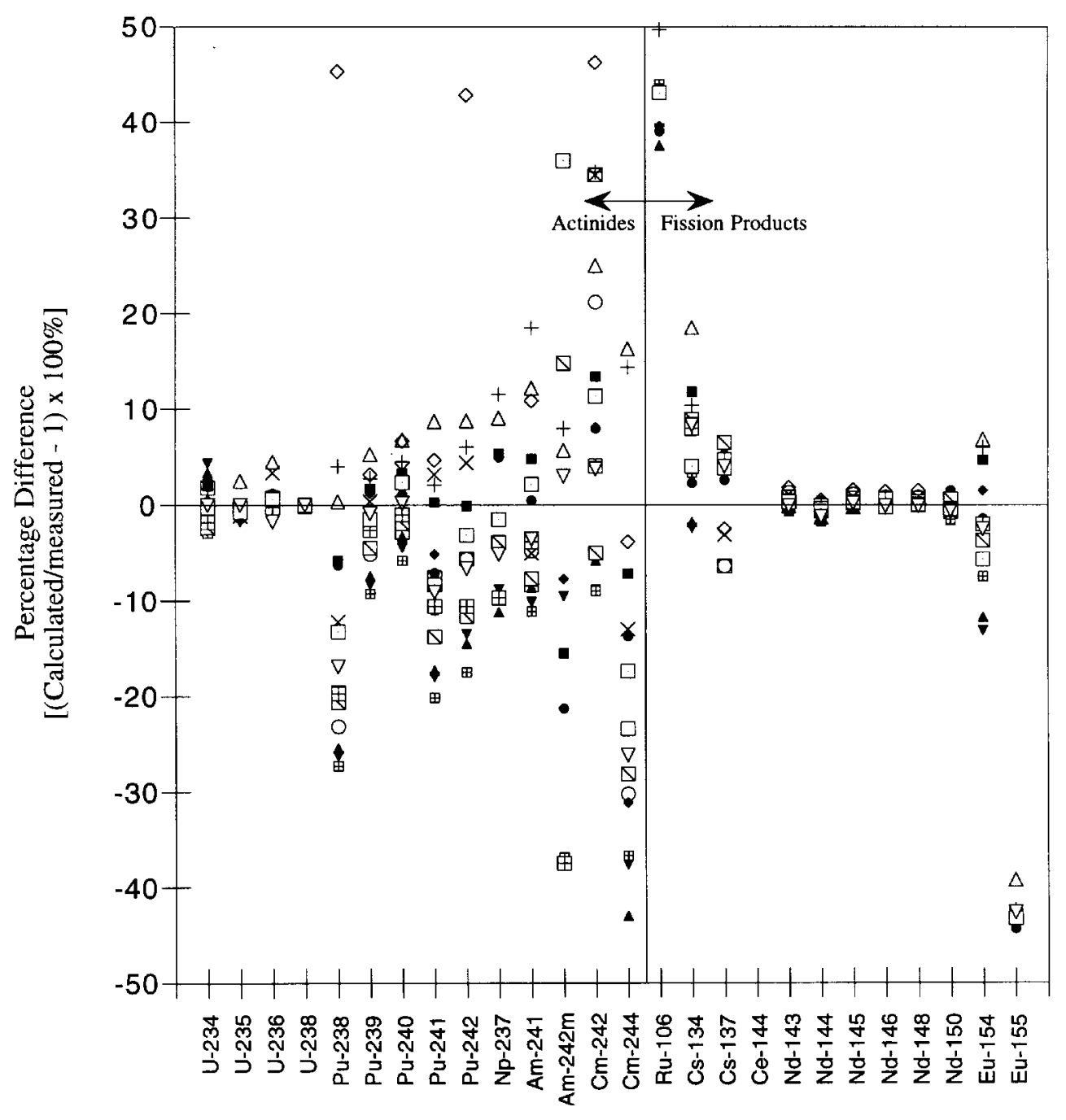

Fig. 8. Percentage differences between measured and calculated results for JPDR fuel samples. 


\subsection{SUMMARY OF ISOTOPIC COMPARISON RESULTS}

Average percentage differences between measured and computed isotopic concentrations combined for all three of the reactors (Cooper, Gundremmingen, and JPDR) are presented in Table 24. This table also provides the number of samples used to calculate the average for each isotopic and the minimum and maximum percentage differences of the cases. These results are also illustrated in Fig. 9. This figure shows all the percentage differences determined for each of the three reactors. All data points from Tables 18, 20, and 23 are shown but are not identified by specific sample. Instead, data points are represented by unique symbols for each reactor type to highlight any differences that might occur as a function of reactor design or operation. Results for ${ }^{126} \mathrm{Sn}$ are not shown in this figure because the magnitude of the error places it off the plot scale.

Statistical estimates of the standard deviation of the sample set of calculated results are given in Table 24 for each nuclide. However, the appropriateness of this statistic requires a normal distribution of results, which was not tested here. However, to test the consistency of the standard deviations calculated for each reactor type, the standard deviations are plotted in bar format for each of the three reactors in Fig. 10. Comparisons are made only for those nuclides for which assays were performed in more than one reactor type. This figure indicates that, for the most part, deviations in the calculated-to-measured ratios are consistent among the three reactor types. This in turn indicates that the three sets of results are statistically similar, and may be grouped together into a single set. 
Table 24. Summary of percentage differences ${ }^{a}$ between measured and computed composition in this BWR validation study as averages and spreads

\begin{tabular}{|c|c|c|c|c|c|c|}
\hline \multirow[b]{2}{*}{ No. } & \multirow[b]{2}{*}{ Nuclide } & \multirow{2}{*}{$\begin{array}{c}\text { No. of } \\
\text { cases }\end{array}$} & \multicolumn{3}{|c|}{ 44GROUPNDF5 data } & \multirow{2}{*}{$\begin{array}{l}\text { Standard } \\
\text { deviation }\end{array}$} \\
\hline & & & Average & Max & Min & \\
\hline 1 & ${ }^{79} \mathrm{Se}$ & 6 & 23.6 & 28.1 & 20.8 & 2.6 \\
\hline 2 & ${ }^{90} \mathrm{Sr}$ & 6 & 8.9 & 10.8 & 5.9 & 1.9 \\
\hline 3 & ${ }^{99} \mathrm{Tc}$ & 6 & 12.1 & 14.6 & 7.0 & 3.1 \\
\hline 4 & ${ }^{106} \mathrm{Ru}$ & 12 & 47.8 & 61.9 & 37.6 & 8.4 \\
\hline 5 & ${ }^{126} \mathrm{Sn}$ & 6 & 205.2 & 218.4 & 195.4 & 8.2 \\
\hline 6 & ${ }^{134} \mathrm{Cs}$ & 20 & 0.9 & 18.5 & -23.4 & 11.4 \\
\hline 7 & ${ }^{135} \mathrm{Cs}$ & 6 & 5.1 & 10.4 & -6.5 & 6.2 \\
\hline 8 & ${ }^{137} \mathrm{Cs}$ & 30 & 1.5 & 17.3 & -13.1 & 5.9 \\
\hline 9 & ${ }^{144} \mathrm{Ce}$ & 12 & 95.5 & 114.7 & 78.8 & 10.9 \\
\hline 10 & ${ }^{143} \mathrm{Nd}$ & 16 & 0.4 & 1.8 & -0.6 & 0.6 \\
\hline 11 & ${ }^{144} \mathrm{Nd}$ & 16 & -0.4 & 0.5 & -1.7 & 0.7 \\
\hline 12 & ${ }^{145} \mathrm{Nd}$ & 16 & 0.4 & 1.6 & -0.4 & 0.5 \\
\hline 13 & ${ }^{146} \mathrm{Nd}$ & 16 & 0.2 & 1.4 & -0.3 & 0.5 \\
\hline 14 & ${ }^{148} \mathrm{Nd}$ & 24 & -0.5 & 1.5 & -4.4 & 1.3 \\
\hline 15 & ${ }^{150} \mathrm{Nd}$ & 16 & -0.3 & 1.5 & -1.6 & 0.9 \\
\hline 16 & ${ }^{154} \mathrm{Eu}$ & 20 & -7.8 & 6.9 & -32.3 & 11.0 \\
\hline 17 & ${ }^{155} \mathrm{Eu}$ & 6 & -42.6 & -39.3 & -44.4 & 1.8 \\
\hline 18 & ${ }^{234} \mathrm{U}$ & 22 & -0.2 & 4.4 & -6.1 & 2.6 \\
\hline 19 & ${ }^{235} \mathrm{U}$ & 30 & -2.0 & 4.0 & -11.7 & 3.3 \\
\hline 20 & ${ }^{236} \mathrm{U}$ & 30 & -1.2 & 4.5 & -7.8 & 2.7 \\
\hline 21 & ${ }^{238} \mathrm{U}$ & 30 & -0.1 & 0.2 & -1.5 & 0.4 \\
\hline 22 & ${ }^{237} \mathrm{~Np}$ & 18 & -1.1 & 17.3 & -11.2 & 8.7 \\
\hline 23 & ${ }^{238} \mathrm{Pu}$ & 30 & -7.0 & 45.3 & -27.3 & 16.3 \\
\hline 24 & ${ }^{239} \mathrm{Pu}$ & 30 & -2.1 & 8.8 & -17.3 & 6.0 \\
\hline 25 & ${ }^{240} \mathrm{Pu}$ & 30 & -0.9 & 6.9 & -11.1 & 4.8 \\
\hline 26 & ${ }^{241} \mathrm{Pu}$ & 30 & -4.5 & 17.1 & -20.1 & 9.3 \\
\hline 27 & ${ }^{242} \mathrm{Pu}$ & 30 & 0.5 & 42.9 & -17.5 & 12.6 \\
\hline 28 & ${ }^{241} \mathrm{Am}$ & 22 & 4.1 & 28.4 & -11.1 & 11.5 \\
\hline 29 & ${ }^{242 \mathrm{~m}} \mathrm{Am}$ & 12 & 2.3 & 88.1 & -37.5 & 34.3 \\
\hline 30 & ${ }^{242} \mathrm{Cm}$ & 16 & 13.5 & 46.3 & -9.0 & 17.5 \\
\hline 31 & ${ }^{243} \mathrm{Cm} .{ }^{244} \mathrm{Cm}$ & 6 & 13.5 & 41.4 & 1.0 & 19.4 \\
\hline 32 & ${ }^{244} \mathrm{Cm}$ & 24 & -19.4 & 16.3 & -57.9 & 15.5 \\
\hline
\end{tabular}

${ }^{a}($ Calculated/measured - 1) $\times 100 \%$. 

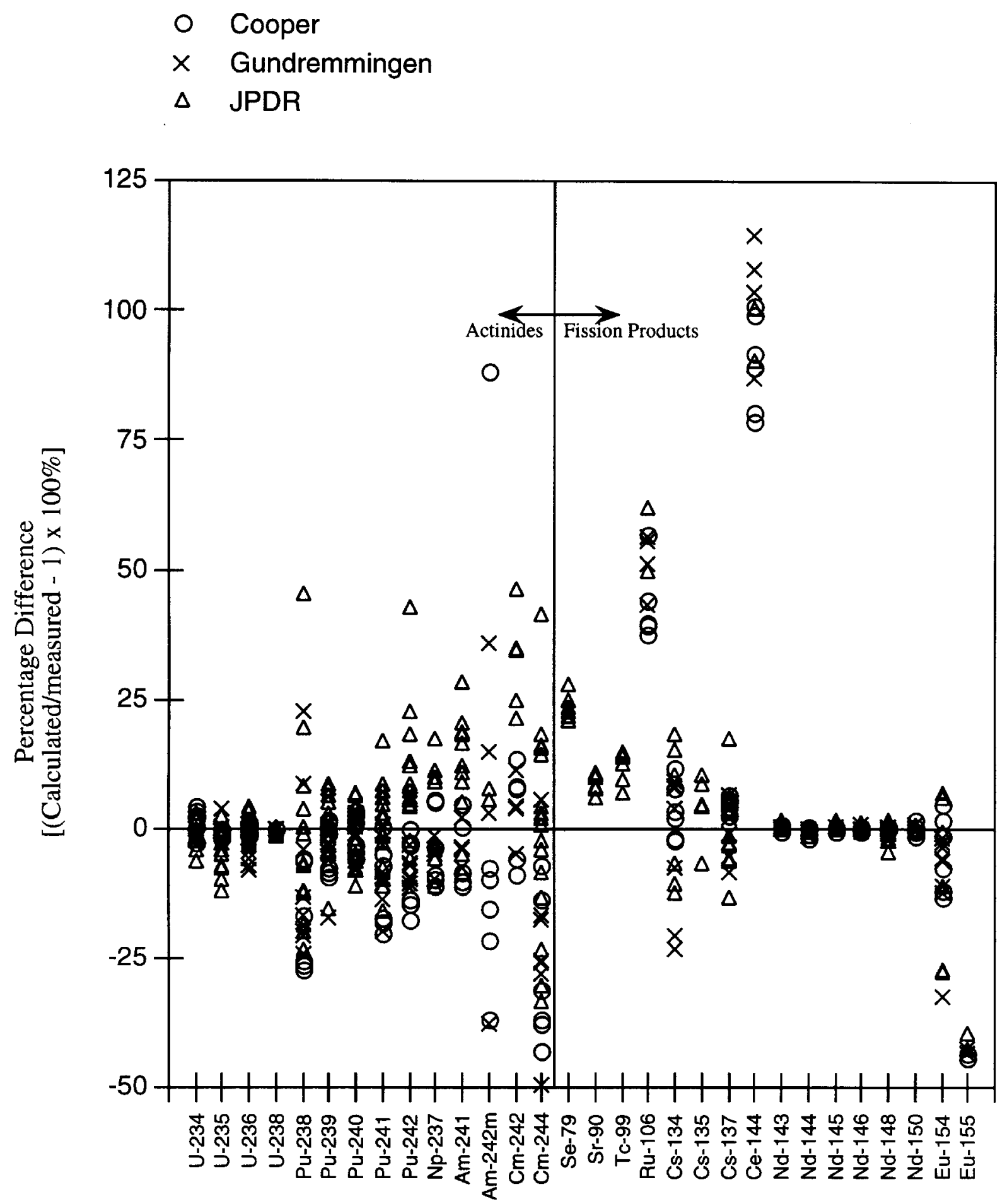

Fig. 9. Percentage differences between measured and calculated results for all fuel samples. 


\section{N Cooper \\ Gundremmingen \\ JPDR}

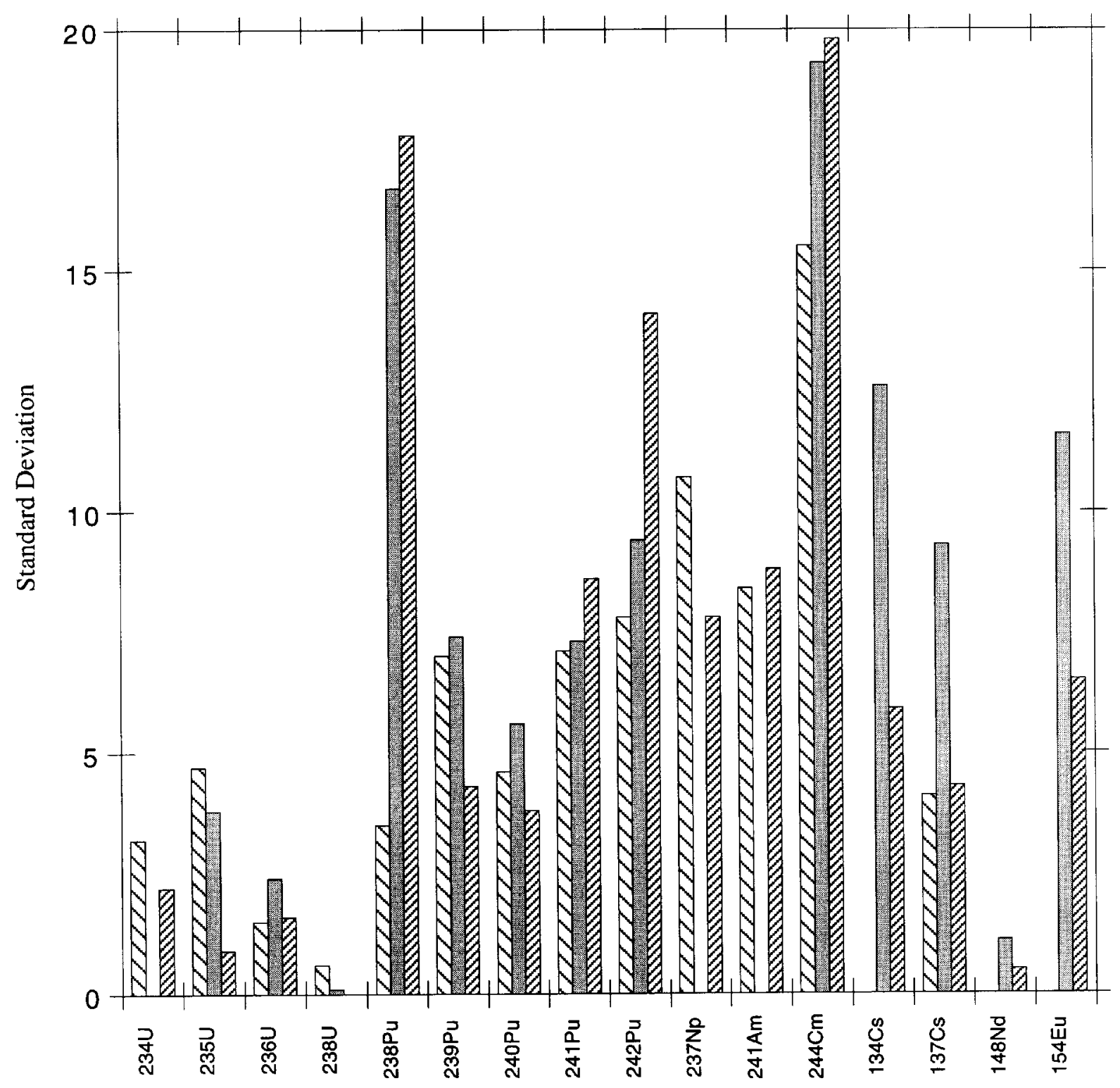

Fig. 10. Standard deviation of isotopic prediction results by reactor type. 


\section{SUMMARY}

Because of the complexity of BWR core dynamics relative to PWR operation, it is generally accepted that isotopic predictions for BWR spent fuel will generally have greater associated uncertainties than for PWR spent fuel. Not only are BWR assembly and core layouts more heterogeneous in terms of material content both radially and axially, but other control procedures generally employed in BWR operation result in variable axial power and neutron spectrum profiles.

Results presented herein demonstrate that isotopic concentrations can be predicted by SAS2H with reasonable accuracy relative to measured data, even with the complexities of the BWR design and operation, for the classes of reactor fuel analyzed. It may be possible to improve estimates of BWR spent fuel contents by refining the modeling approach. For example, to address the effect of variable enrichments within an assembly design, it would be necessary to repeat these analyses using more detailed multidimensional transport methods to obtain a better estimate of the local neutron flux at the location of the fuel sample. A set of scoping calculations were performed to estimate the effect of variations in moderator density on depletion calculations. The results are summarized in Appendix $\mathrm{H}$. To address the effect of moderator density variations more fully, it would be necessary to use more refined methods to estimate the axial moderator density.

More important than the need to refine the current computational approach is the need to extend the set of computational comparisons to measured data. Not only are there few if any measurements for important fission product nuclides, but also the number of different reactor designs and operational patterns are poorly represented by the small subset of measurements presented in this report. Furthermore, although the measured data from JPDR have value, especially for low-burnup fuel located near the ends of reactor fuel rods, the number of measurements of JPDR fuel samples relative to the other samples may introduce a bias in results due to conditions unique in the JPDR design. Finally, from a statistical point of view, it is desirable to use as many data points as possible to ensure the best possible estimate of bias and uncertainty for predicted spent fuel isotopic concentrations. 


\section{REFERENCES}

1. SCALE. A Modular Code System for Performing Standardized Computer Analyses for Licensing Evaluation, NUREG/CR-0200, Rev. 5 (ORNL/NUREG/CSD-2/R5), Vols. I-III, (March 1997). Available from Radiation Safety Information Computational Center, Oak Ridge National Laboratory, as CCC-545.

2. T. L. Sanders and R. M. Westfall, "Feasibility and Incentives for Burnup Credit in Spent Fuel Transport Casks,” Nucl. Sci. Eng. 104 (1990).

3. M. D. DeHart, Sensitivity and Parametric Evaluations of Significant Aspects of Burnup Credit for PWR Spent Fuel Packages, ORNL/TM-12973, Lockheed Martin Energy Research Corp., Oak Ridge Natl. Lab., May 1996.

4. S. M. Bowman, M. D. DeHart, and C. V. Parks, "Validation of SCALE-4 for Burnup Credit Applications," Nucl. Tech. 110 (1995).

5. M. D. DeHart and C. V. Parks, "Issues Related to Criticality Safety Analysis for Burnup Credit," Fifth International Conference on Nuclear Criticality Safety, Albuquerque, N.M., September 17-21, 1995.

6. "American National Standard for Nuclear Criticality Safety in Operations with Fissionable Materials Outside Reactors,” ANSI/ANS-8.1-1983, American Nuclear Society, 1983.

7. M. D. DeHart, O. W. Hermann, and C. V. Parks, "Validation of a Method for Prediction of Isotopic Concentrations in Burnup Credit Applications," Fifth International Conference on Nuclear Criticality Safety, Albuquerque, N.M., September 17-21, 1995. 
8. O. W. Hermann, S. M. Bowman, M. C. Brady, and C. V. Parks, Validation of the SCALE System for PWR Spent Fuel Isotopic Composition Analyses, ORNL/TM-12667, Martin Marietta Energy Systems, Inc., Oak Ridge Natl. Lab., 1995.

9. M. D. DeHart and O. W. Hermann, An Extension of the Validation of SCALE (SAS2H) Isotopic Predictions for PWR Spent Fuel, ORNL/TM-13317, Lockheed Martin Energy Research Corp., Oak Ridge Natl. Lab., September 1996.

10. R. J. Guenther et al., Characterization of Spent Fuel Approved Testing Material - ATM-105, PNL-5109-105, Pacific Northwest Laboratory, 1991.

11. Y. Naito, M. Kurosawa, and T. Kaneko, Data Book of the Isotopic Composition of Spent Fuel in Light Water Reactors, JAERI-M 94-034, Japan Atomic Energy Research Institute, 1994.

12. P. Barbero et al., Post-Irradiation Analysis of the Gundremmingen BWR Spent Fuel, EUR6301en, Joint Research Center Ispra and Karlsruhe Establishments, 1979.

13. The Evaluated Nuclear Data File, Versions IV, $V$, and VI (ENDF/B-IV, V, and VI), maintained by the National Data Center at Brookhaven National Laboratory.

14. M. D. DeHart and S. M. Bowman, Validation of the SCALE Broad Structure 44-Group ENDF/B-V Cross-Section Library for Use in Criticality Safety Analyses, NUREG/CR-6102 (ORNL/TM-12460), U.S. Nuclear Regulatory Commission, 1994.

15. R. Q. Wright, "Fission Product Evaluations for ENDF/B-VI," Trans. Am. Nucl. Soc. 61, 398-99 (1990). 
16. O. W. Hermann, C. V. Parks, and J. P. Renier, Technical Support for a Proposed Decay Heat Guide Using SAS2H/ORIGEN-S Data, NUREG/CR-5625 (ORNL-6698), U.S. Nuclear Regulatory Commission, 1994.

17. U.S. Department of Energy, Characteristics of Potential Repository Wastes, DOE/RW-0184R1, Vol. 1, Oak Ridge Natl. Lab., July 1992.

18. M. A. McKinnon, C. M. Heeb, and J. M. Creen, Decay Heat Measurements and Predictions of BWR Spent Fuel, EPRI NP-4619, Electric Power Research Institute, June 1986.

19. O. W. Hermann et al., Multicode Comparison of Selected Source Term Computer Codes, ORNL/CSD/TM-251, Martin Marietta Energy Systems, Inc., Oak Ridge Natl. Lab., April 1989. 


\section{APPENDIX A \\ DESCRIPTION OF THE SCALE SAS2H DEPLETION APPROACH}

SCALE is a well-established code system that has been widely used in away-from-reactor (AFR) applications for spent fuel characterization via the SAS2H analysis sequence $\mathrm{SAS} 2 \mathrm{H}$ is a multicode sequence that determines the isotopic composition of spent fuel using the ORIGEN-S code ${ }^{\text {A.2 }}$ for depletion and decay calculations and a 1-D neutronics model of a fuel assembly to prepare burnup-dependent cross sections for ORIGEN-S. Isotopic concentrations used in the subsequent spent fuel criticality calculations are based on the results of SAS2H calculations.

The SAS2H control module was originally developed for the SCALE code system to provide a sequence that generated radiation source terms for spent fuel and subsequently to utilize these sources with a 1-D shielding analysis of a shipping cask. However, in addition to the calculation of radiation source terms, SAS2H is now often used to obtain decay heat and depleted fuel isotopics. Within the scope of validation activities described in this report, SAS2H is used solely for the prediction of burnup-depleted isotopics in spent fuel.

Six different modules are invoked by the SAS2H sequence for performing a complete fuel depletion analysis. The SCALE-4 system driver provides automated data handling and code execution for each step of the process. This procedure begins with the SCALE Material Information

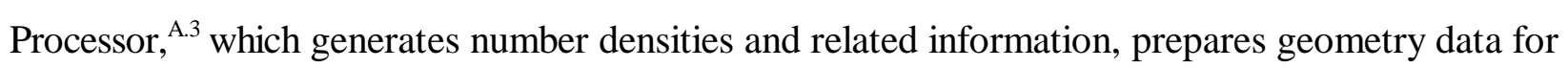
resonance self-shielding and flux-weighting cell calculations, and creates data input files for the cross-section processing codes. BONAMI ${ }^{\mathrm{A} .4}$ applies the Bondarenko method of resonance selfshielding for nuclides which have Bondarenko data included in the cross-section library. NITAWLII ${ }^{A .5}$ performs Nordheim resonance self-shielding corrections for nuclides that have resonance parameters included with their cross-section data. XSDRNPN ${ }^{\mathrm{A} .6}$ is a 1-D discrete-ordinates code that performs radiation transport calculations based on geometric data passed to it by SAS2H and produces cell-weighted cross sections for fuel depletion calculations. The COUPLE code $\frac{A .7}{\text { updates }}$ cross-section constants included on the ORIGEN-S nuclear data library with data from the cellweighted cross-section library produced by XSDRNPM. COUPLE also uses the XSDRNPMcomputed weighting spectrum to update nuclide cross sections for remaining nuclides. Finally, the 
ORIGEN-S code is used to perform nuclide generation and depletion calculations for a specified reactor fuel history.

The process used by SAS2H in calculation of spent fuel isotopics is illustrated schematically in Fig. A.1. The calculation starts with input-specified data that describe a fuel assembly as it is initially loaded into a reactor. The initial composition, average temperatures, geometry, and timedependent specific power of the fuel assembly are required. The SAS2H sequence performs 1-D neutron transport analysis of the reactor fuel assembly using XSDRNPM and a two-part procedure with two separate unit-cell-lattice models. The first model (Path A of Fig. A.1) is a unit fuel-pin cell from which cell-weighted cross sections are obtained. The second model (Path B of Fig. A.1) represents a larger unit cell (e.g., an assembly) within an infinite lattice. The larger unit cell zones can be structured for different assembly designs to account for assembly-specific attributes (i.e., water holes, burnable poison rods, etc.). Problem-dependent resonance self-shielding of cross sections is performed prior to each XSDRNPM calculation using the BONAMI and NITAWL-II codes. The neutron flux spectrum obtained from the second (assembly) unit-cell model is used to determine the appropriate nuclide cross sections for the burnup-dependent fuel composition. The cross sections derived from XSDRNPM calculations at each time step are used in an ORIGEN-S point-depletion computation that produces the burnup-dependent fuel compositions to be used in the next spectrum calculation. This sequence is repeated in user-specified burnup steps for a complete assembly operating history. The buildup and decay of nuclides in the fuel assembly is then computed by ORIGEN-S in a final pass based on the cooling time (i.e., the period of time after final exposure time) of the assembly. Note that ORIGEN-S calculations have no spatial dependence. The neutron flux used to produce the ORIGEN-S cross sections is based on a radial average of an infinitely long uniform assembly with characteristics per input specifications. These specifications (e.g., burnup, specific power, moderator temperature, etc.) can be representative of any axial location along the fuel assembly or an axial average of the fuel assembly. 


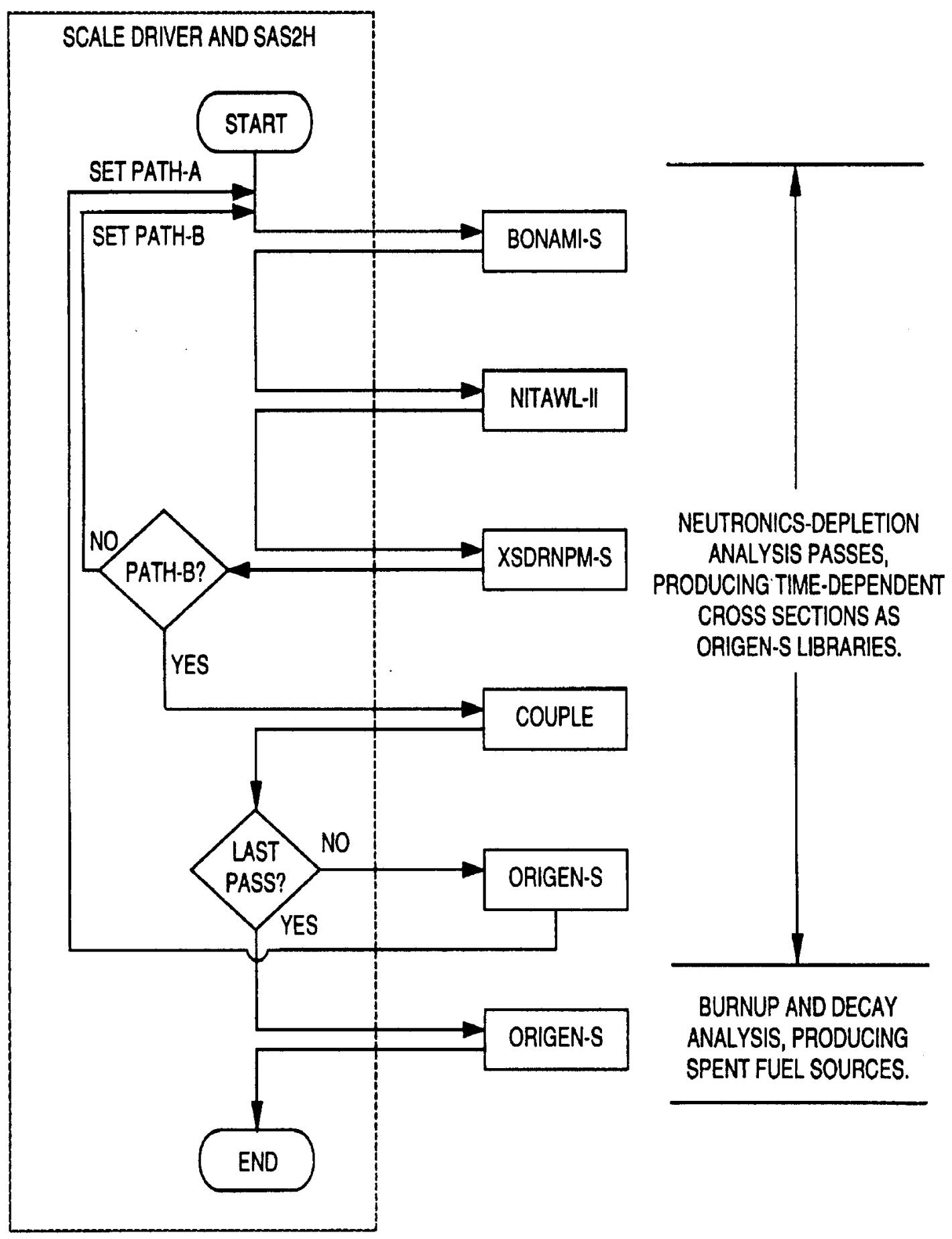

Fig. A.1. Flow path invoked in SAS2H depletion and decay sequences. 
More than 1000 nuclides are tracked by ORIGEN-S during depletion and decay calculations. (Note that ORIGEN-S tracks all decay chains but does not account for the loss of volatile isotopes; however, any released nuclides represent an insignificant fraction of the total fission-product inventory, and their inclusion should have an insignificant effect on the isotopic calculations.) In the current work, burnup-dependent cross sections were processed by SAS2H only for the select set of user-specified nuclides listed in Table A.1. These nuclides are consistent with the set of nuclides found to be significant to the depletion analyses in prior studies.8,A.9 for validation of the use of SCALE/SAS2H to predict isotopic compositions of PWR spent fuel. Cross sections for remaining isotopes are obtained from the ORIGEN-S one-group LWR library and are adjusted with burnup using ORIGEN-S spectral parameters (THERM, RES, and FAST) calculated using fluxes determined by XSDRNPM. The ORIGEN-S one-group LWR library available in SCALE-4.3 has been updated to use cross sections from the SCALE-4.3 27-group burnup library for all of the approximately 200 nuclides in that library. The update was performed by extracting one-group cross sections from the output of a low-burnup LWR-type fuel.

Table A.1. Nuclides updated by SAS2H

\begin{tabular}{lllll}
\hline${ }^{234} \mathrm{U}^{a}$ & ${ }^{235} \mathrm{U}^{a}$ & ${ }^{236} \mathrm{U}^{a}$ & ${ }^{238} \mathrm{U}^{a}$ & ${ }^{237} \mathrm{~Np}^{a}$ \\
${ }^{238} \mathrm{Pu}^{a}$ & ${ }^{239} \mathrm{Pu}^{a}$ & ${ }^{240} \mathrm{Pu}^{a}$ & ${ }^{241} \mathrm{Pu}^{a}$ & ${ }^{242} \mathrm{Pu}^{a}$ \\
${ }^{241} \mathrm{Am}^{a}$ & ${ }^{242} \mathrm{Am}^{a, b}$ & ${ }^{243} \mathrm{Am}^{a}$ & ${ }^{242} \mathrm{Cm}^{a, b}$ & ${ }^{243} \mathrm{Cm}^{a, b}$ \\
${ }^{244} \mathrm{Cm}^{a}$ & ${ }^{10} \mathrm{~B}$ & ${ }^{11} \mathrm{~B}$ & ${ }^{16} \mathrm{O}$ & ${ }^{94} \mathrm{Zr}$ \\
${ }^{95} \mathrm{Nb}$ & ${ }^{95} \mathrm{Mo}$ & ${ }^{99} \mathrm{Tc}$ & ${ }^{106} \mathrm{Ru}$ & ${ }^{103} \mathrm{Rh}$ \\
${ }^{105} \mathrm{Rh}$ & ${ }^{126} \mathrm{Sn}$ & ${ }^{131} \mathrm{Xe}$ & ${ }^{135} \mathrm{Xe}^{a}$ & ${ }^{133} \mathrm{Cs}^{a}$ \\
${ }^{134} \mathrm{Cs}$ & ${ }^{135} \mathrm{Cs}$ & ${ }^{137} \mathrm{Cs}$ & ${ }^{144} \mathrm{Ce}$ & ${ }^{143} \mathrm{Pr}$ \\
${ }^{143} \mathrm{Nd}$ & ${ }^{144} \mathrm{Nd}$ & ${ }^{145} \mathrm{Nd}$ & ${ }^{146} \mathrm{Nd}$ & ${ }^{147} \mathrm{Nd}$ \\
${ }^{148} \mathrm{Nd}$ & ${ }^{150} \mathrm{Nd}$ & ${ }^{147} \mathrm{Pm}$ & ${ }^{148} \mathrm{Pm}$ & ${ }^{149} \mathrm{Pm}$ \\
${ }^{147} \mathrm{Sm}$ & ${ }^{148} \mathrm{Sm}$ & ${ }^{149} \mathrm{Sm}$ & ${ }^{150} \mathrm{Sm}$ & ${ }^{151} \mathrm{Sm}$ \\
${ }^{152} \mathrm{Sm}$ & ${ }^{151} \mathrm{Eu}$ & ${ }^{153} \mathrm{Eu}$ & ${ }^{154} \mathrm{Eu}$ & ${ }^{155} \mathrm{Eu}$ \\
\hline
\end{tabular}

${ }^{a}$ Automatically updated by SAS2H if nuclide cross sections are in the SCALE master library requested.

${ }^{b}$ Nuclide included in the 44-group library but not in the 27-group burnup library. 
The quantity of a light element contained in the fuel assembly, if not included in the model as a material in a mixture input to SAS2H, may be input as kilograms of the element per assembly, per metric ton $\mathrm{U}(\mathrm{MTU})$, or per metric ton $\mathrm{UO}_{2}\left(\mathrm{MT} \mathrm{UO}_{2}\right)$. The units should correspond to the type of units used in the radiochemical assay measurements (i.e., either per gram U, or per gram $\mathrm{UO}_{2}$ ). The generic quantities of significant light elements for BWR fuel.10 used in this study are given in Table A.2.

Table A.2. Element contents ${ }^{a}$ from clad, structure, and moderator for a generic BWR

\begin{tabular}{ccc}
\hline Element & $\mathrm{kg} / \mathrm{MTU}$ & $\mathrm{kg} / \mathrm{MT} \mathrm{UO} \mathrm{U}_{2}$ \\
\hline $\mathrm{H}$ & 16.4 & 14.5 \\
$\mathrm{O}$ & 265.0 & 236.0 \\
$\mathrm{Cr}$ & 2.4 & 2.1 \\
$\mathrm{Mn}$ & 0.15 & 0.13 \\
$\mathrm{Fe}$ & 6.6 & 5.8 \\
$\mathrm{Ni}$ & 2.4 & 2.1 \\
$\mathrm{Zr}$ & 516.0 & 455.0 \\
$\mathrm{Sn}$ & 8.7 & 7.7 \\
\hline
\end{tabular}

${ }^{a}$ Calculated from data and factors in ref. A.10.

\section{A.1 References}

A.1 O. W. Hermann and C. V. Parks, "SAS2H: A Coupled One-Dimensional Depletion and Shielding Analysis Code," Sect. S2 of SCALE: A Modular Code System for Performing Standardized Computer Analyses for Licensing Evaluation, NUREG/CR-0200, Rev. 4 (ORNL/NUREG/CSD-2/R4), Vols. I, II, and III (April 1995). Available from Radiation Shielding Information Center as CCC-545.

A.2 O. W. Hermann and R. M. Westfall, “ORIGEN-S: A SCALE System Module to Calculate Fuel-Depletion, Actinide Transmutation, Fission Product Buildup and Decay, and Associated Radiation Source Terms," Sect. F7 of SCALE: A Modular Code System for Performing Standardized Computer Analyses for Licensing Evaluation, NUREG/CR-0200, Rev. 4 (ORNL/NUREG/CSD-2/R4), Vols. I, II, and III (April 1995). Available from Radiation Shielding Information Center as CCC-545. 
A.3 N. F. Landers et al., "The Material Information Processor for SCALE," Sect. M7 of SCALE: A Modular Code System for Performing Standardized Computer Analyses for Licensing Evaluation, NUREG/CR-0200, Rev. 4 (ORNL/NUREG/CSD-2/R4), Vols. I, II, and III (April 1995). Available from Radiation Shielding Information Center as CCC-545.

A.4 N. M. Greene, "BONAMI: Resonance Self-Shielding by the Bondarenko Method," Sect. F1 of SCALE: A Modular Code System for Performing Standardized Computer Analyses for Licensing Evaluation, NUREG/CR-0200, Rev. 4 (ORNL/NUREG/CSD-2/R4), Vols. I, II, and III (April 1995). Available from Radiation Shielding Information Center as CCC-545.

A.5 N. M. Greene, "NITAWL-II: SCALE System Module for Performing Resonance Shielding and Working Library Production," Sect. F2 of SCALE: A Modular Code System for Performing Standardized Computer Analyses for Licensing Evaluation, NUREG/CR-0200, Rev. 4 (ORNL/NUREG/CSD-2/R4), Vols. I, II, and III (April 1995). Available from Radiation Shielding Information Center as CCC-545.

A.6 N. M. Greene and L. M. Petrie, "XSDRNPM: A One-Dimensional Discrete-Ordinates Code for Transport Analysis," Sect. F3 of SCALE: A Modular Code System for Performing Standardized Computer Analyses for Licensing Evaluation, NUREG/CR-0200, Rev. 4 (ORNL/NUREG/CSD-2/R4), Vols. I, II, and III (April 1995). Available from Radiation Shielding Information Center as CCC-545.

A.7 O. W. Hermann, "COUPLE: SCALE System Module to Process Problem-Dependent Cross Sections and Neutron Spectral Data for ORIGEN-S Analyses," Sect. F6 of SCALE: A Modular Code System for Performing Standardized Computer Analyses for Licensing Evaluation, NUREG/CR-0200, Rev. 4 (ORNL/NUREG/CSD-2/R4), Vols. I, II, and III (April 1995). Available from Radiation Shielding Information Center as CCC-545.

A.8 O. W. Hermann, S. M. Bowman, M. C. Brady, and C. V. Parks, Validation of the SCALE System for PWR Spent Fuel Isotopic Composition Analyses, ORNL/TM-12667, Martin Marietta Energy Systems, Inc., Oak Ridge Natl. Lab., 1995.

A.9 M. D. DeHart and O. W. Hermann, An Extension of the Validation of SCALE (SAS2H) Isotopic Predictions for PWR Spent Fuel, ORNL/TM-12496, Lockheed Martin Energy Research Corp., Oak Ridge Natl. Lab. (to be published).

A.10 A. G. Croff et al,, Revised Uranium-Plutonium Cycle PWR and BWR Models for the ORIGEN Computer Code, ORNL/TM-6051, Union Carbide Corp., Nucl. Div., Oak Ridge Natl. Lab., 1978. 
APPENDIX B

INPUT LISTINGS FOR COOPER BWR SAS2H DEPLETION CALCULATIONS

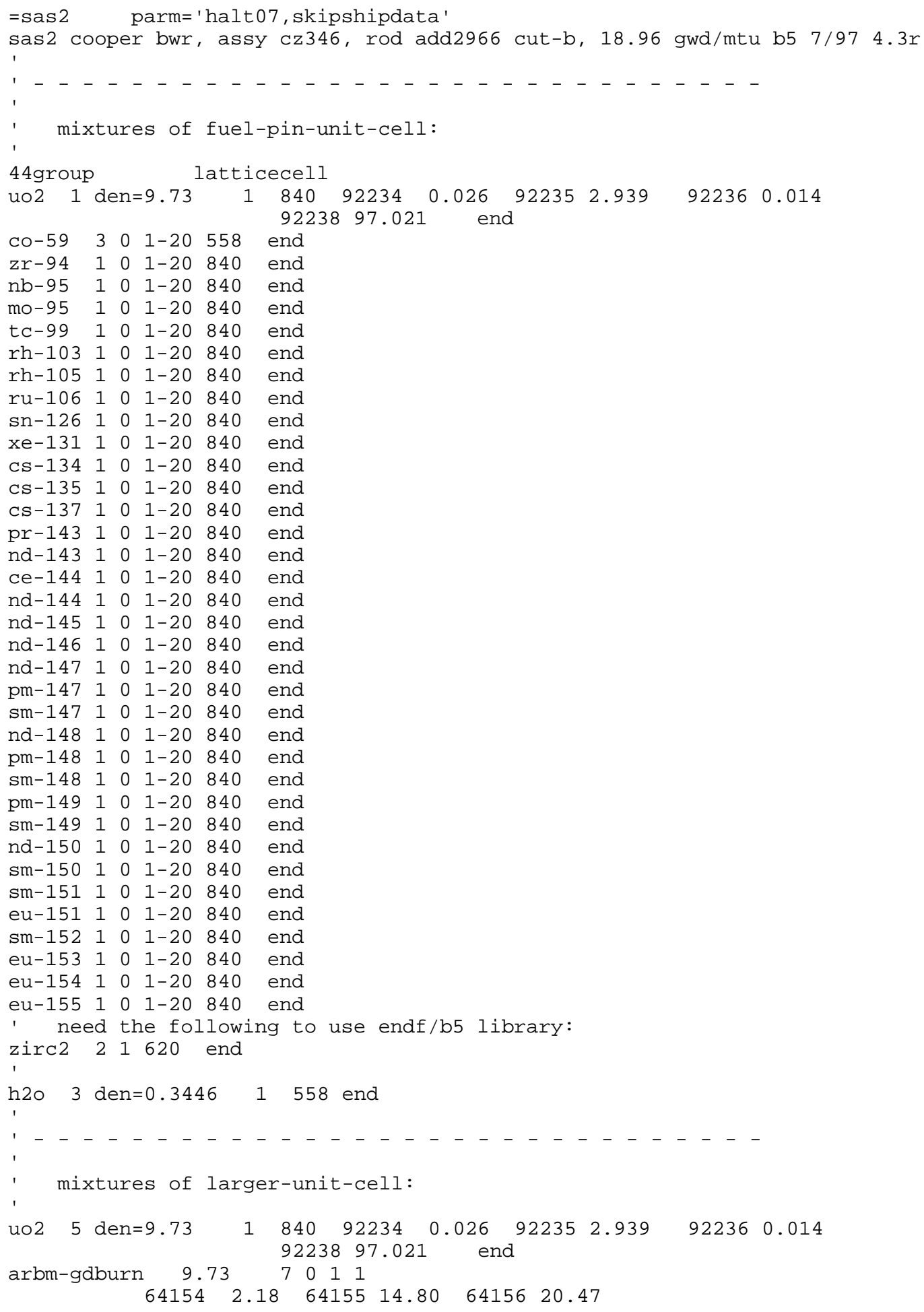




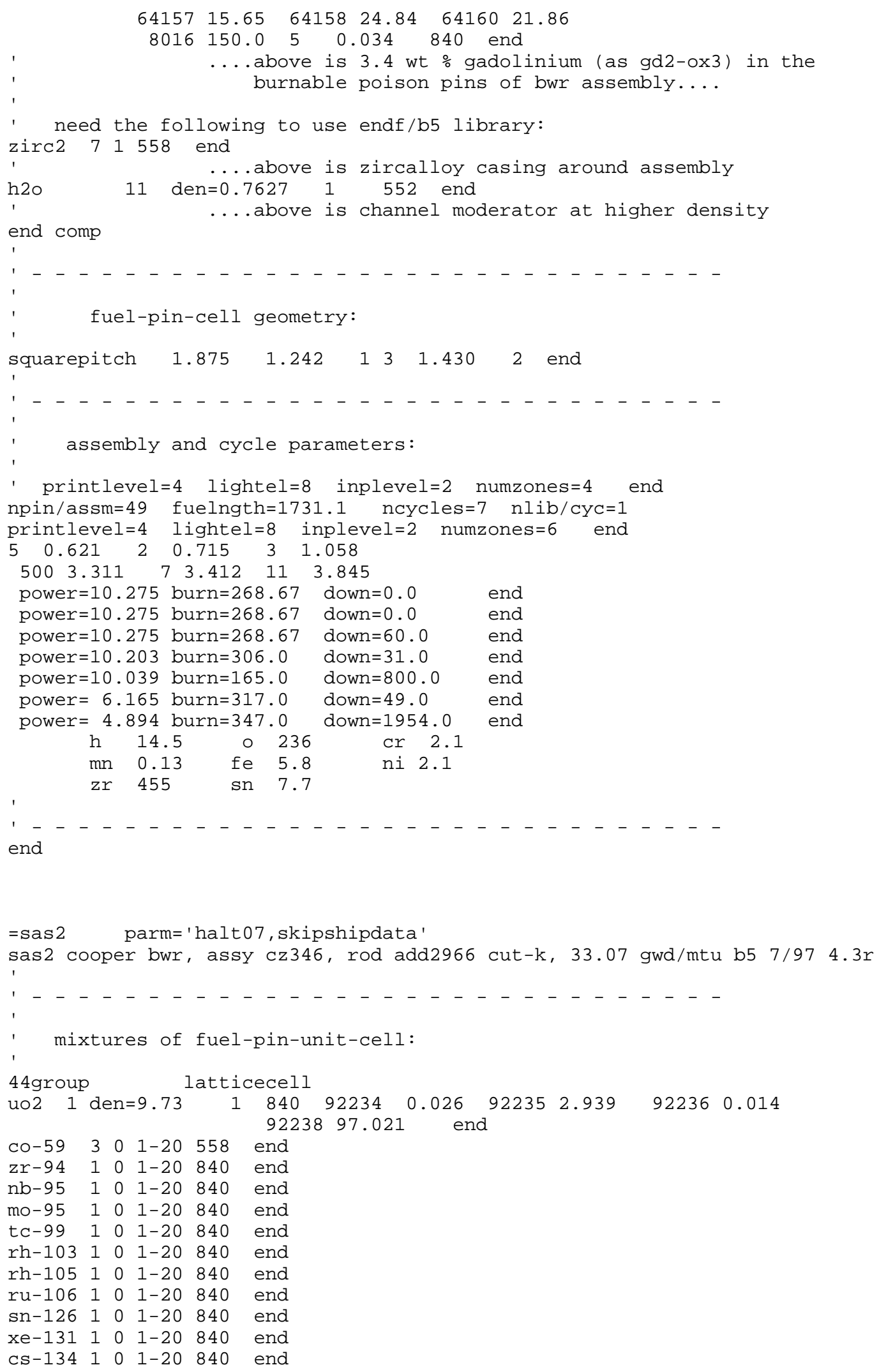




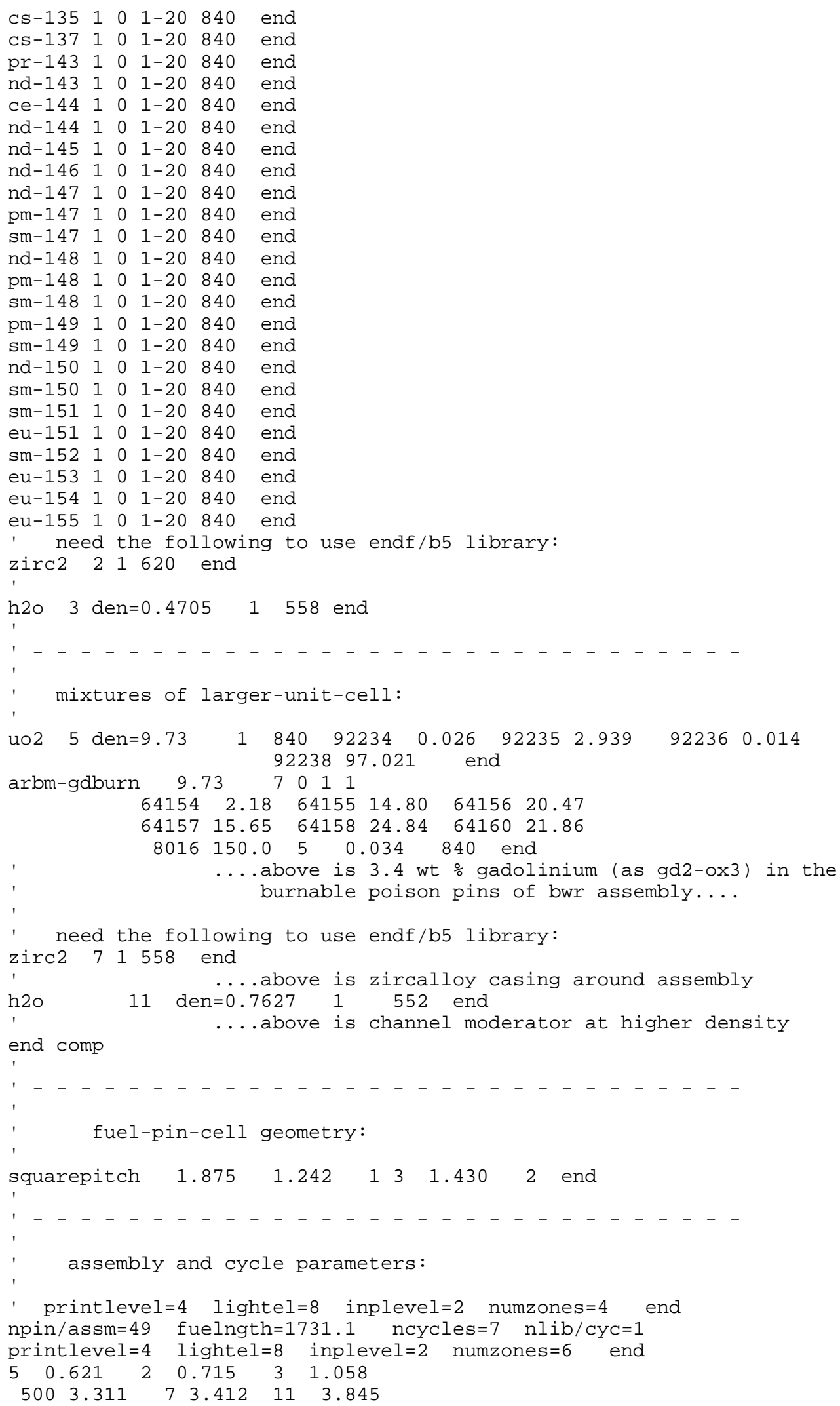




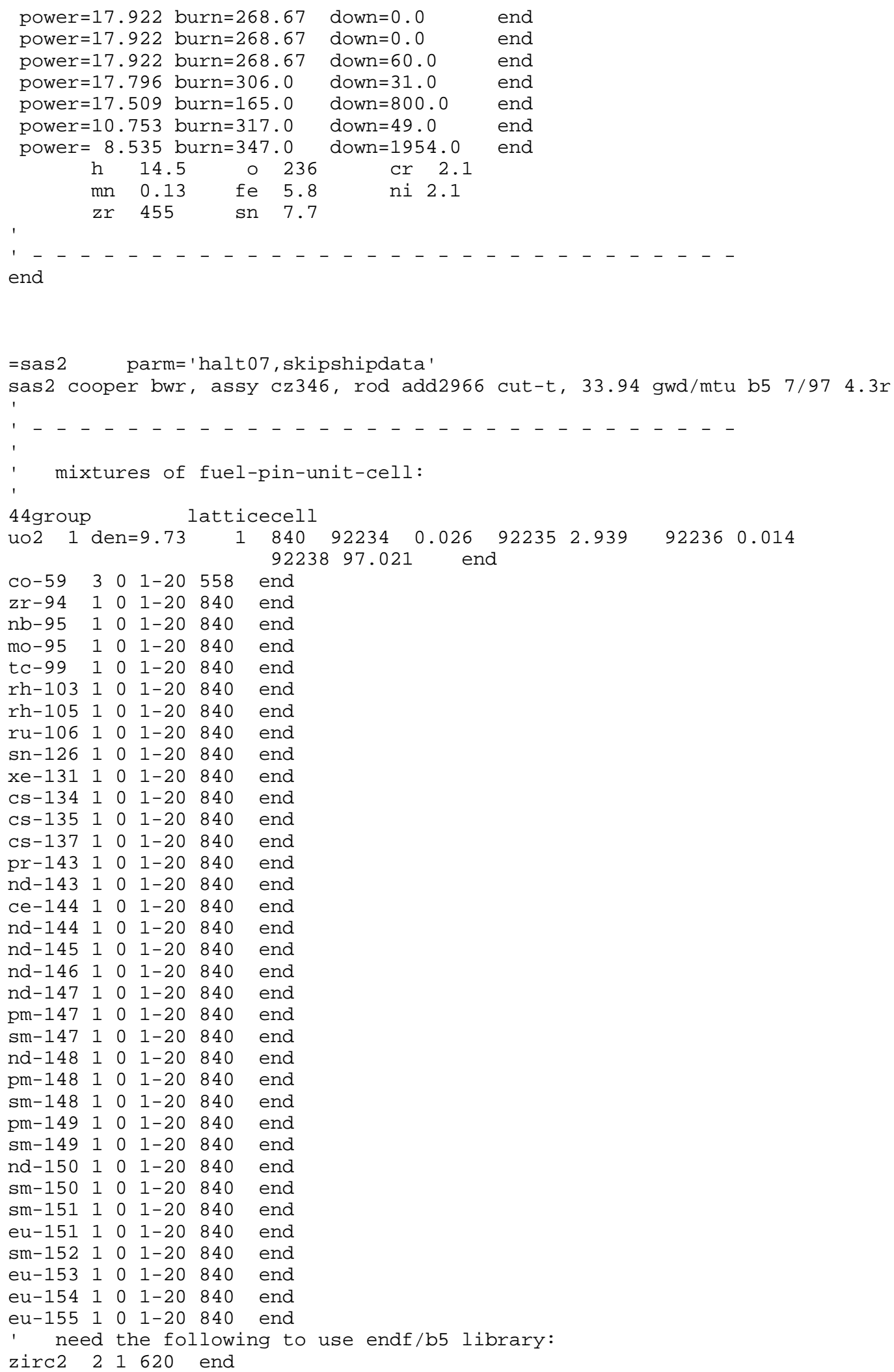




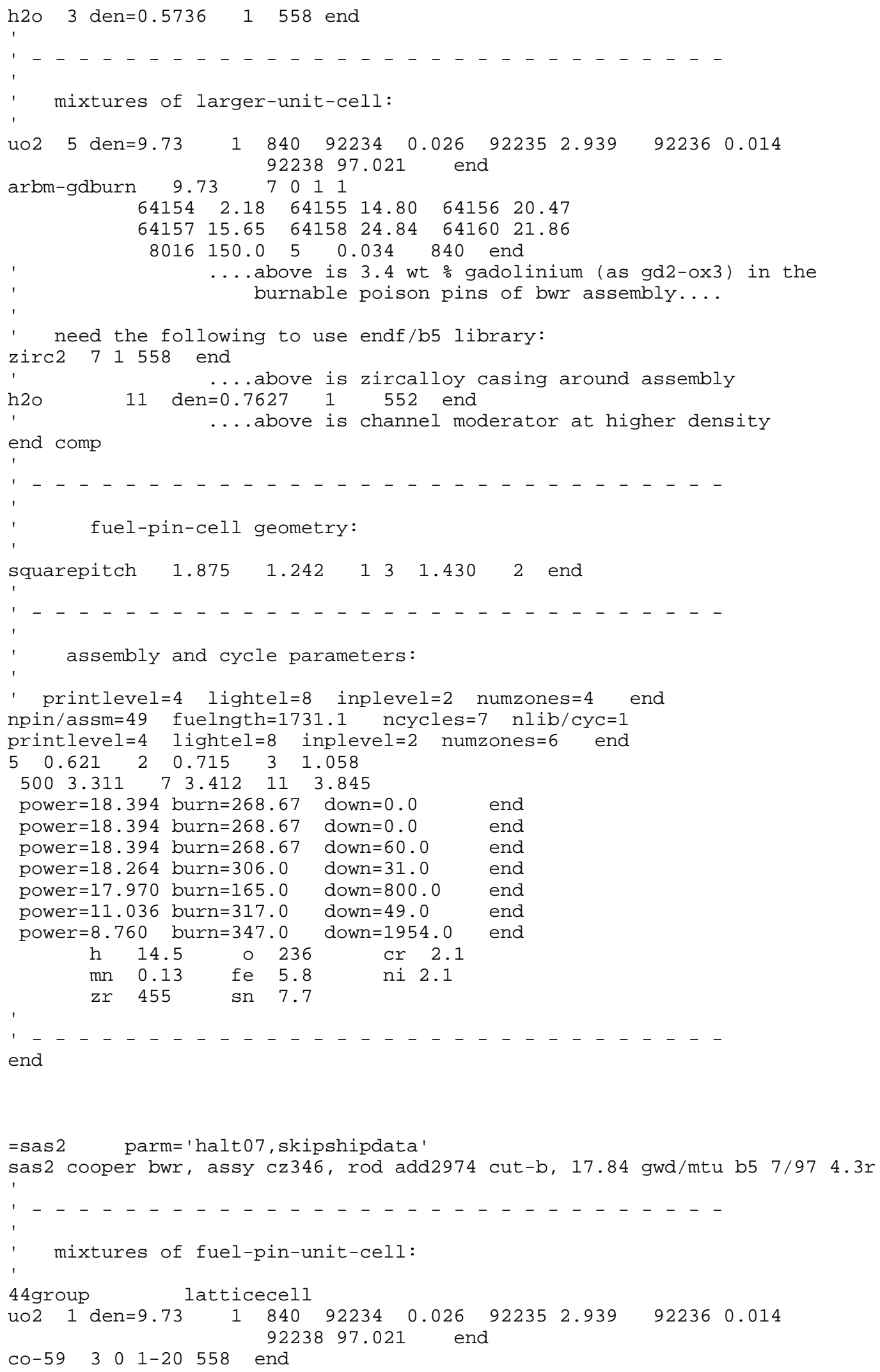




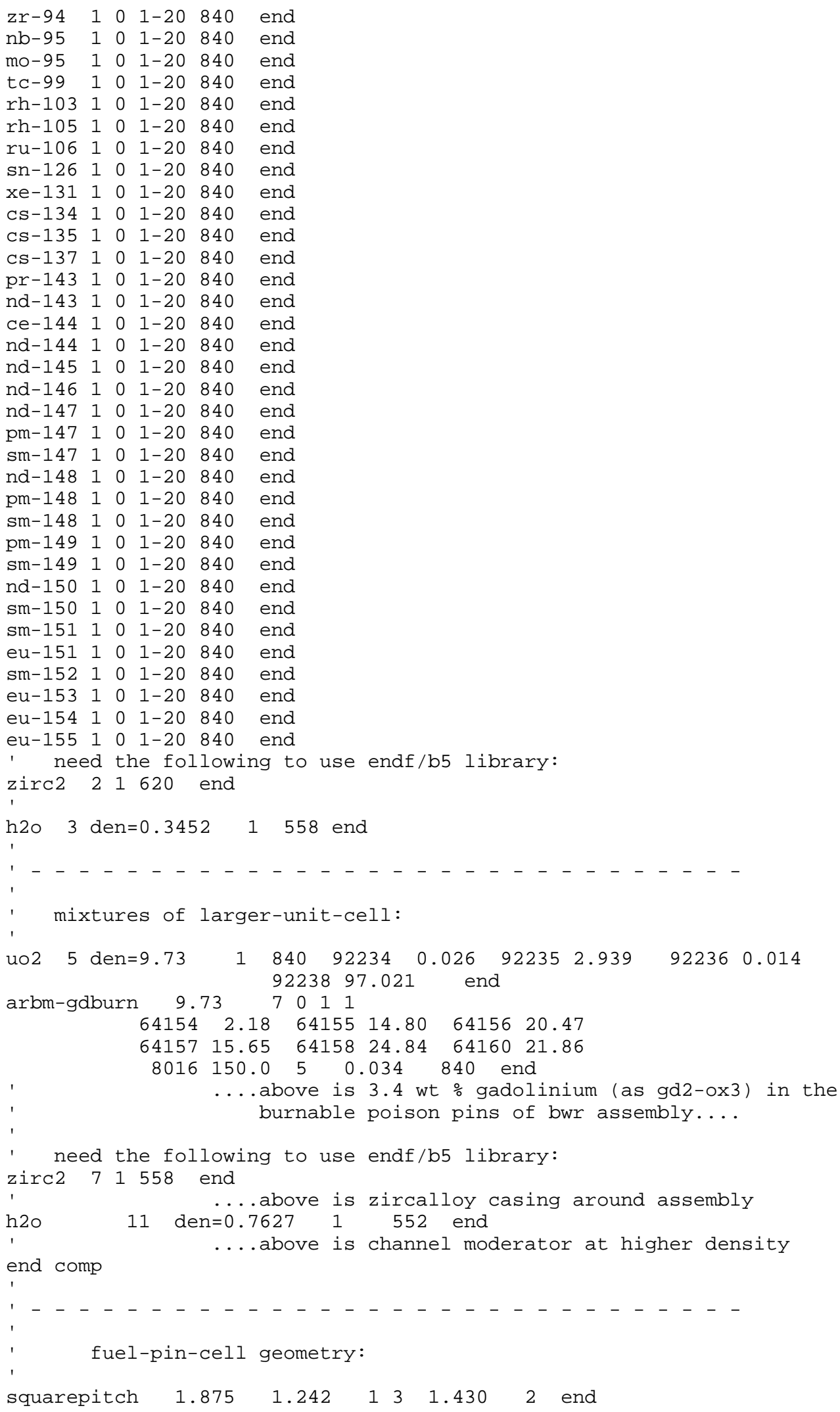




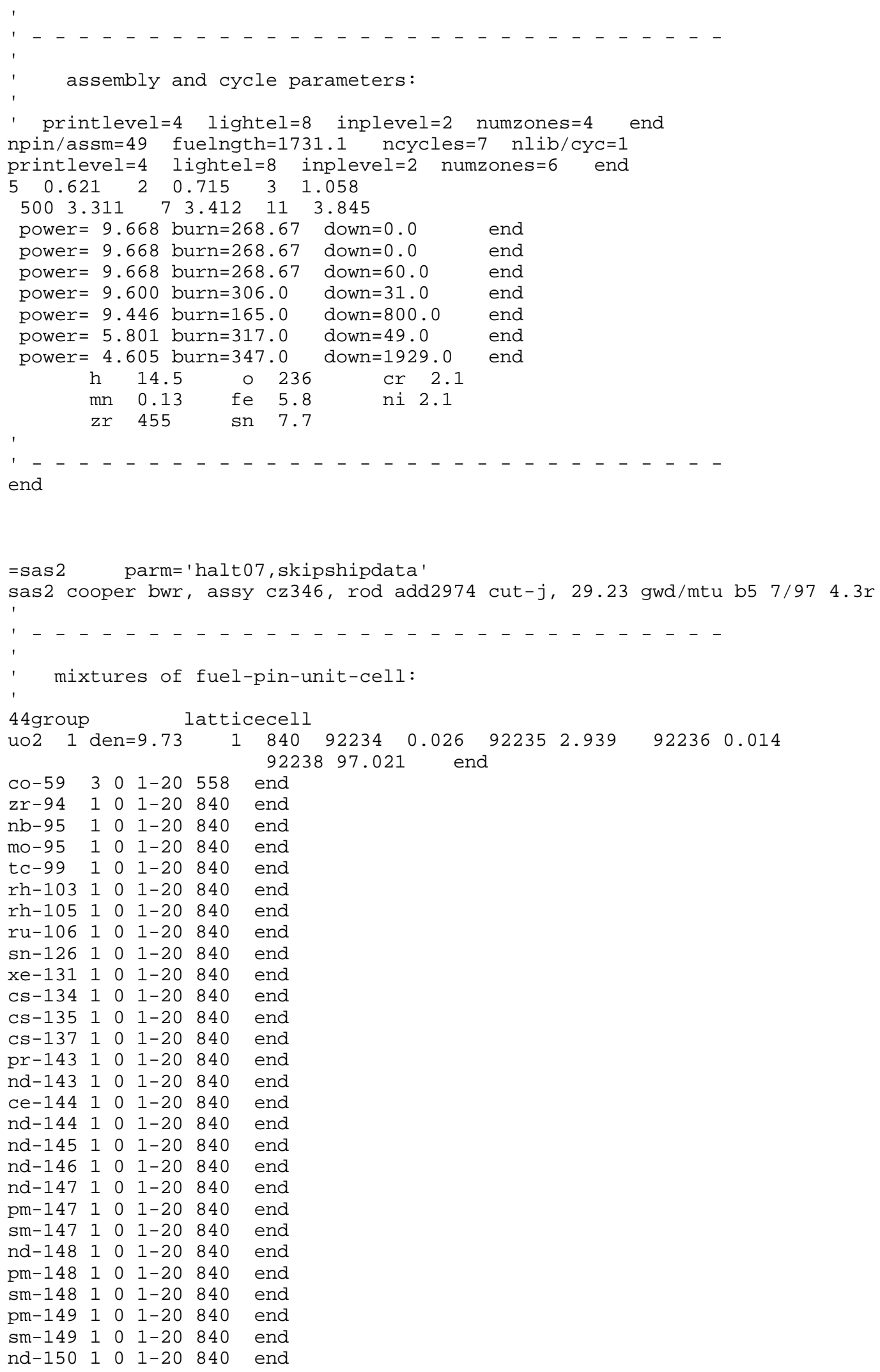




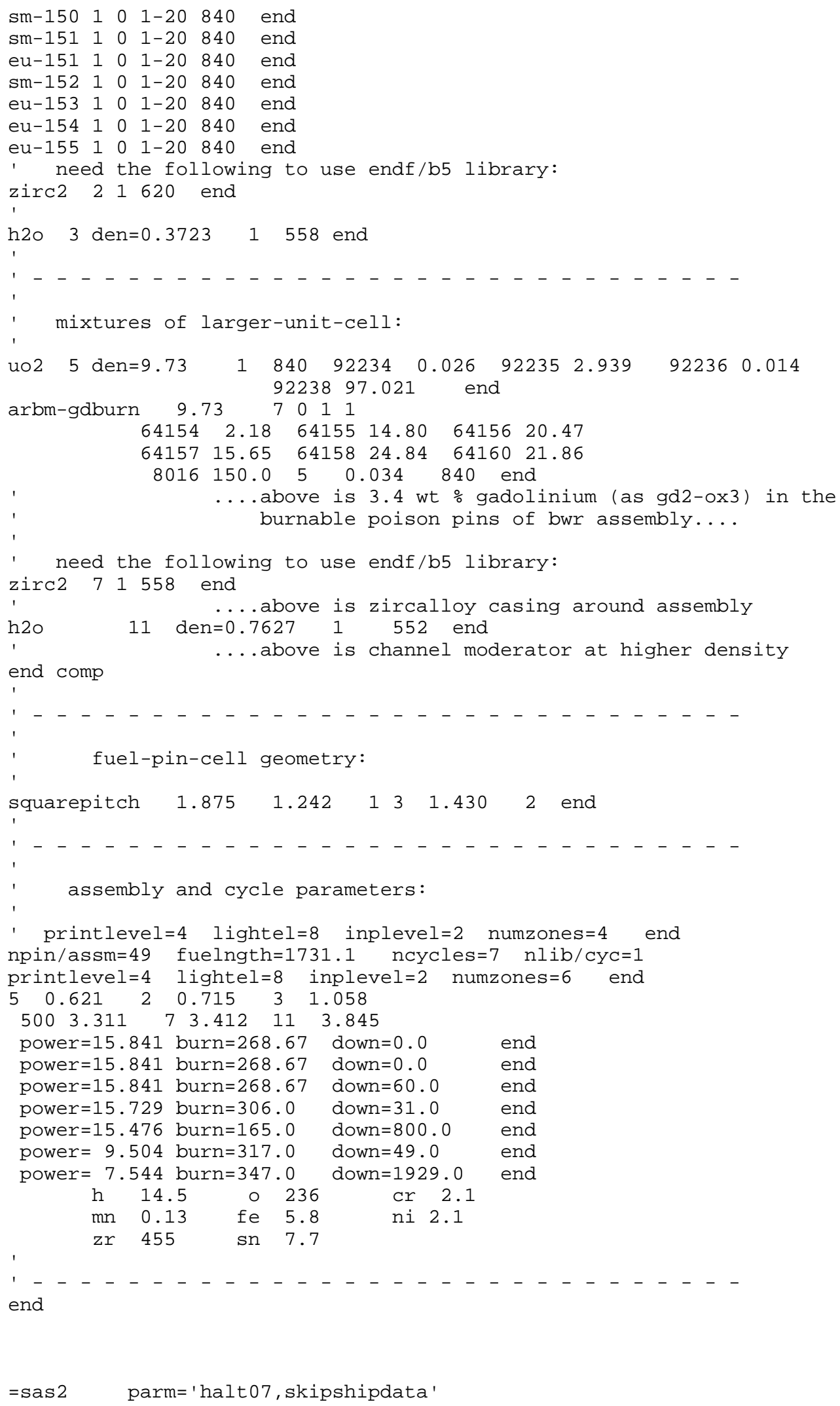




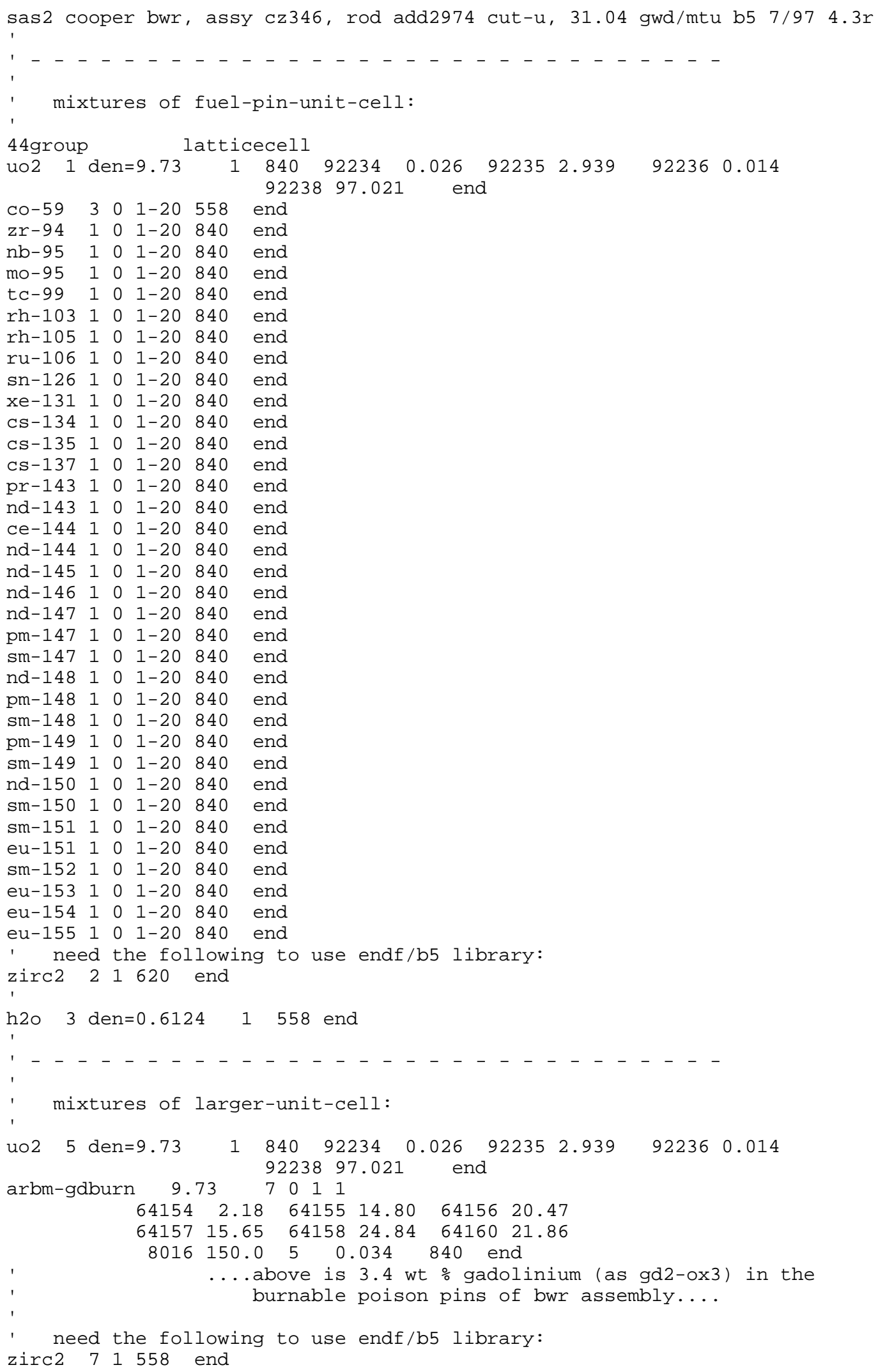




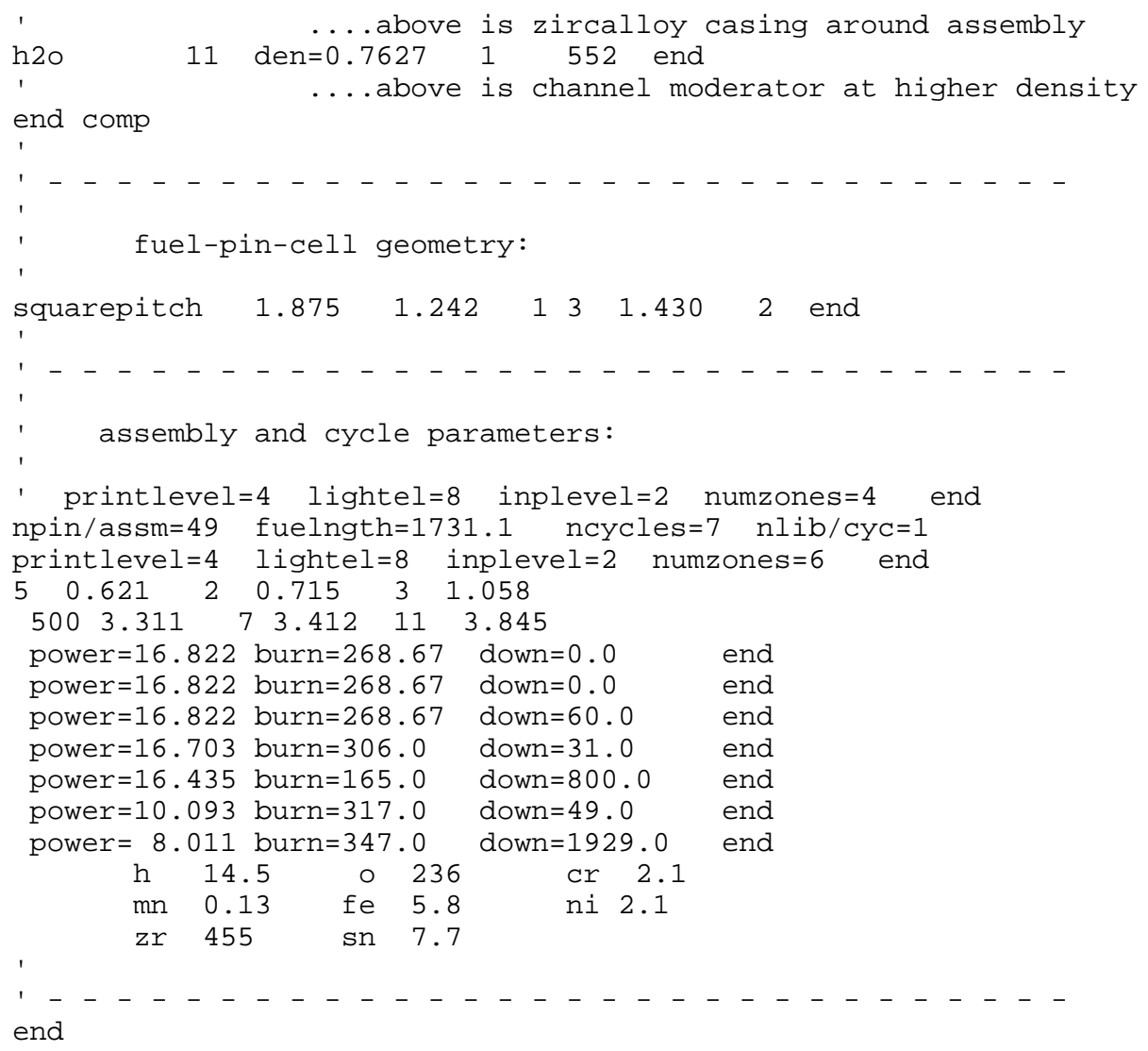


APPENDIX C

INPUT LISTINGS FOR GUNDREMMINGEN BWR

SAS2H DEPLETION CALCULATIONS

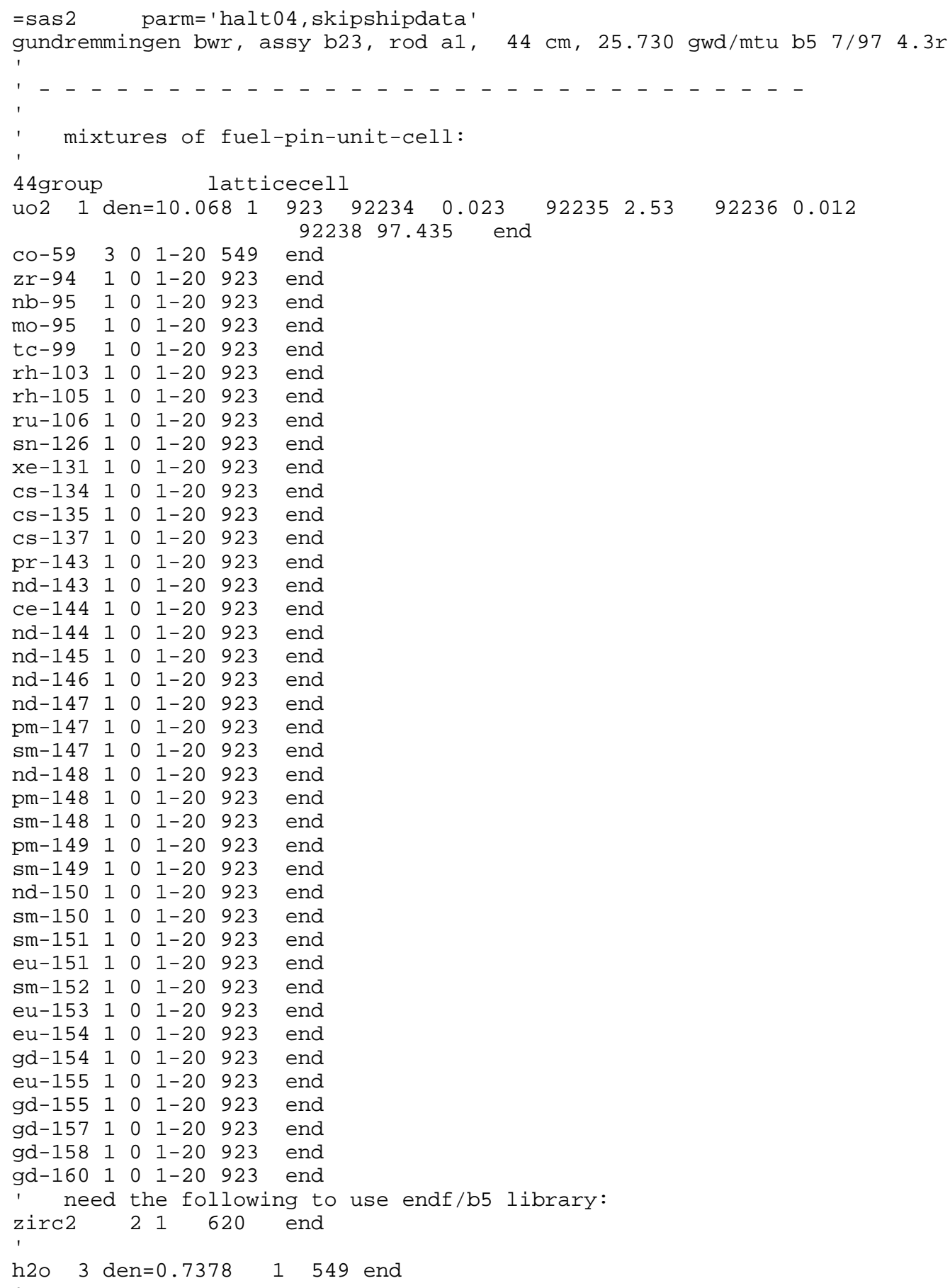




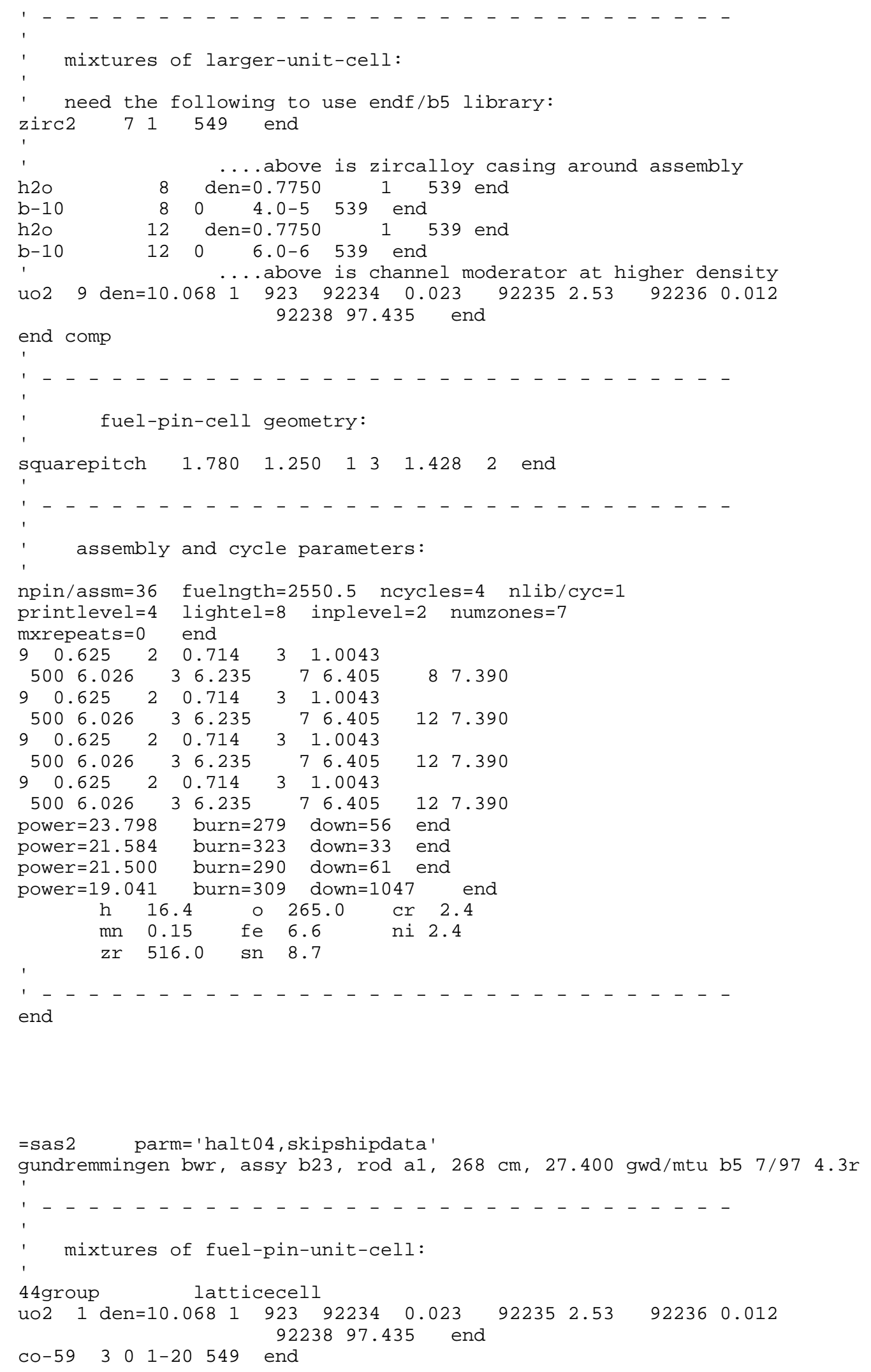




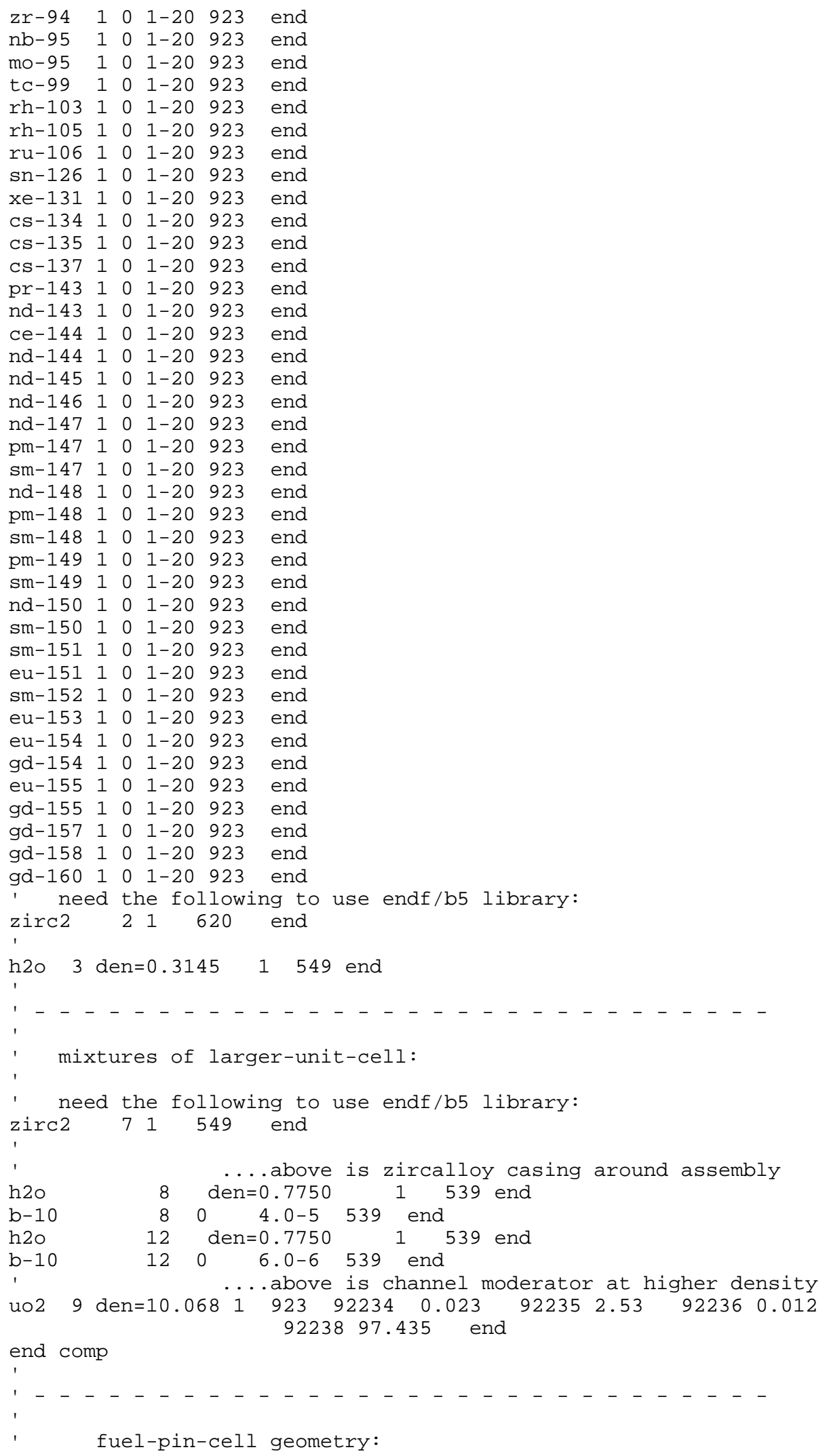




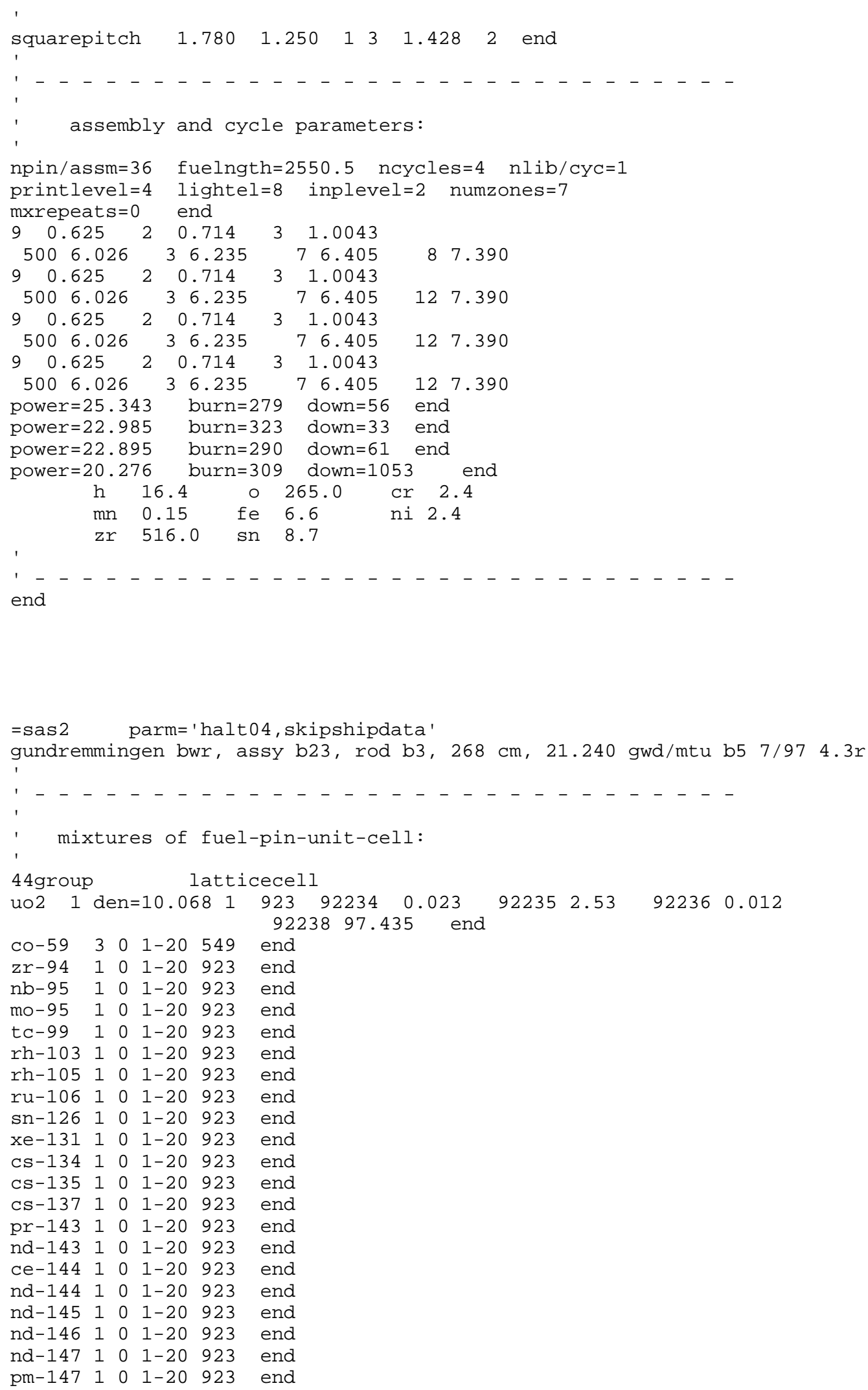




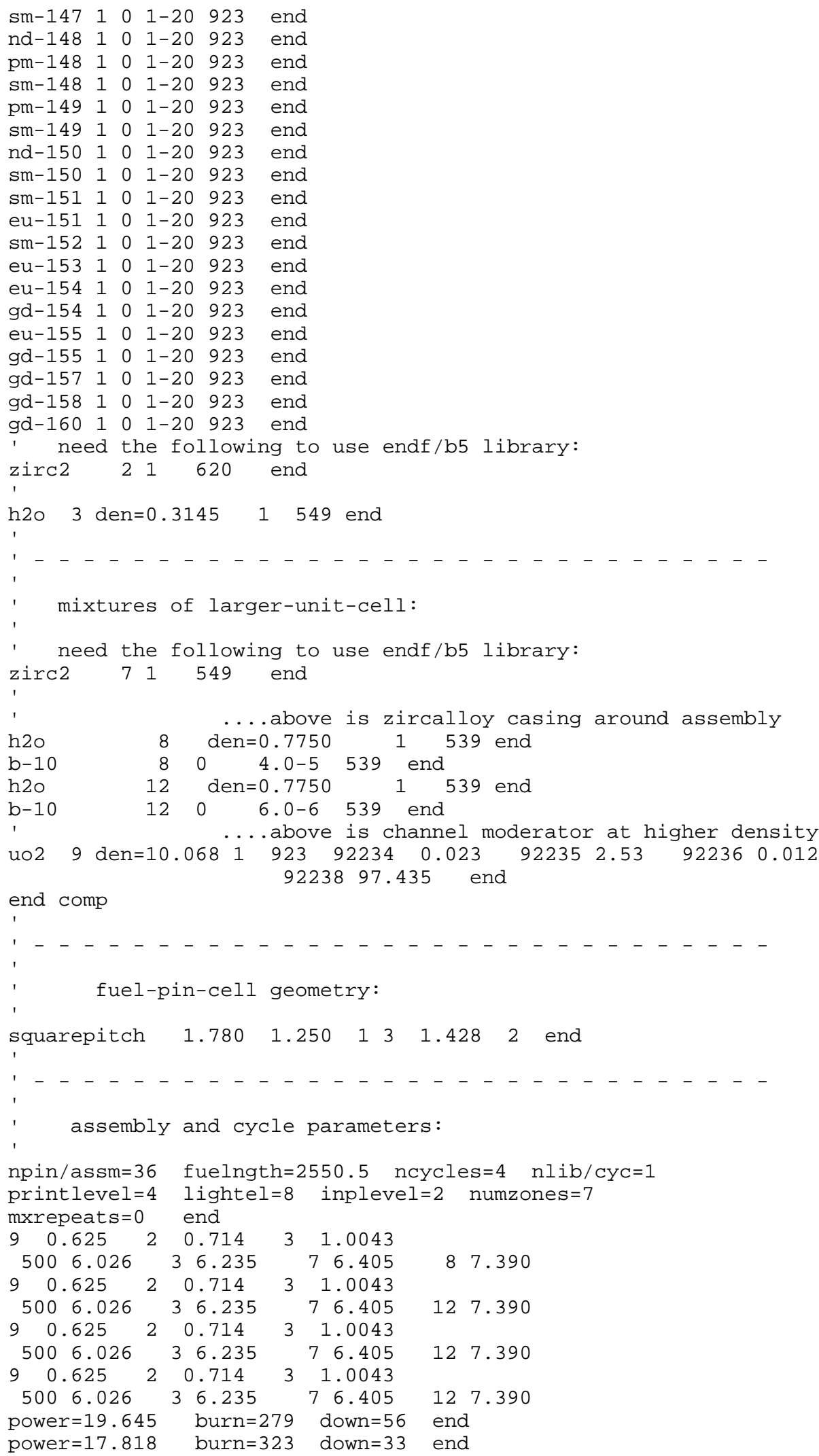




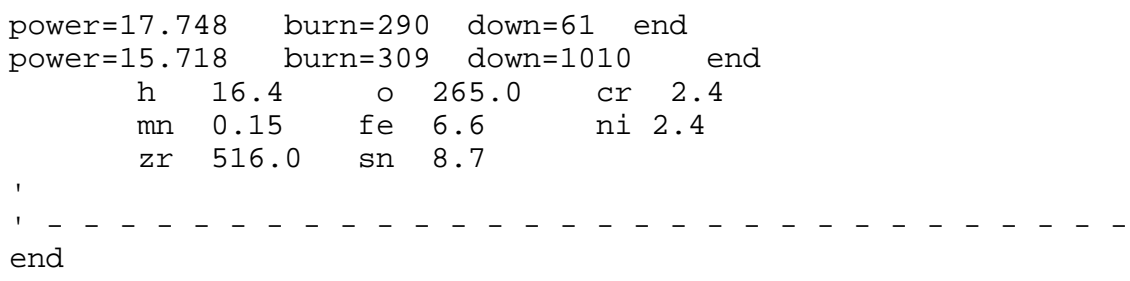




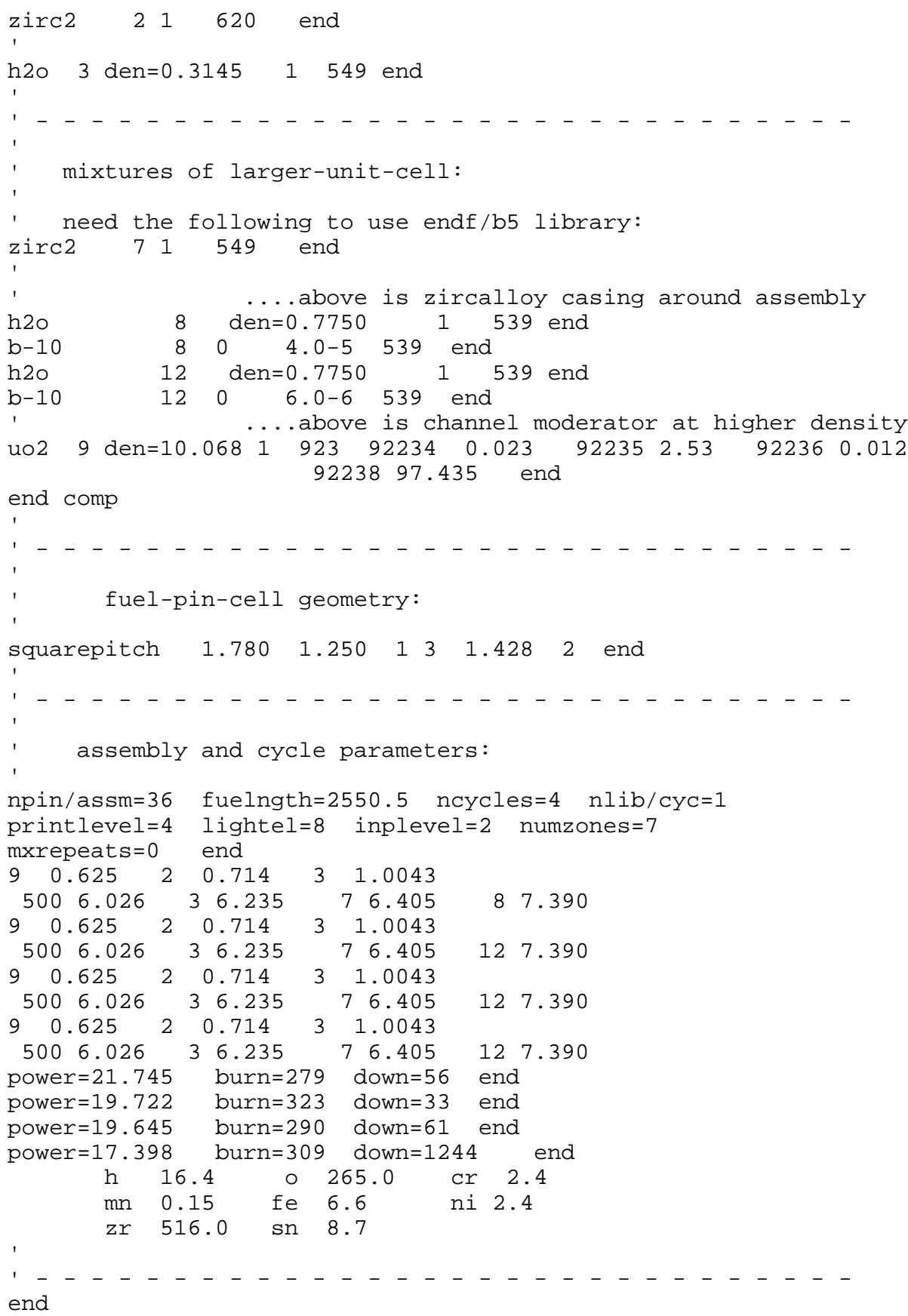




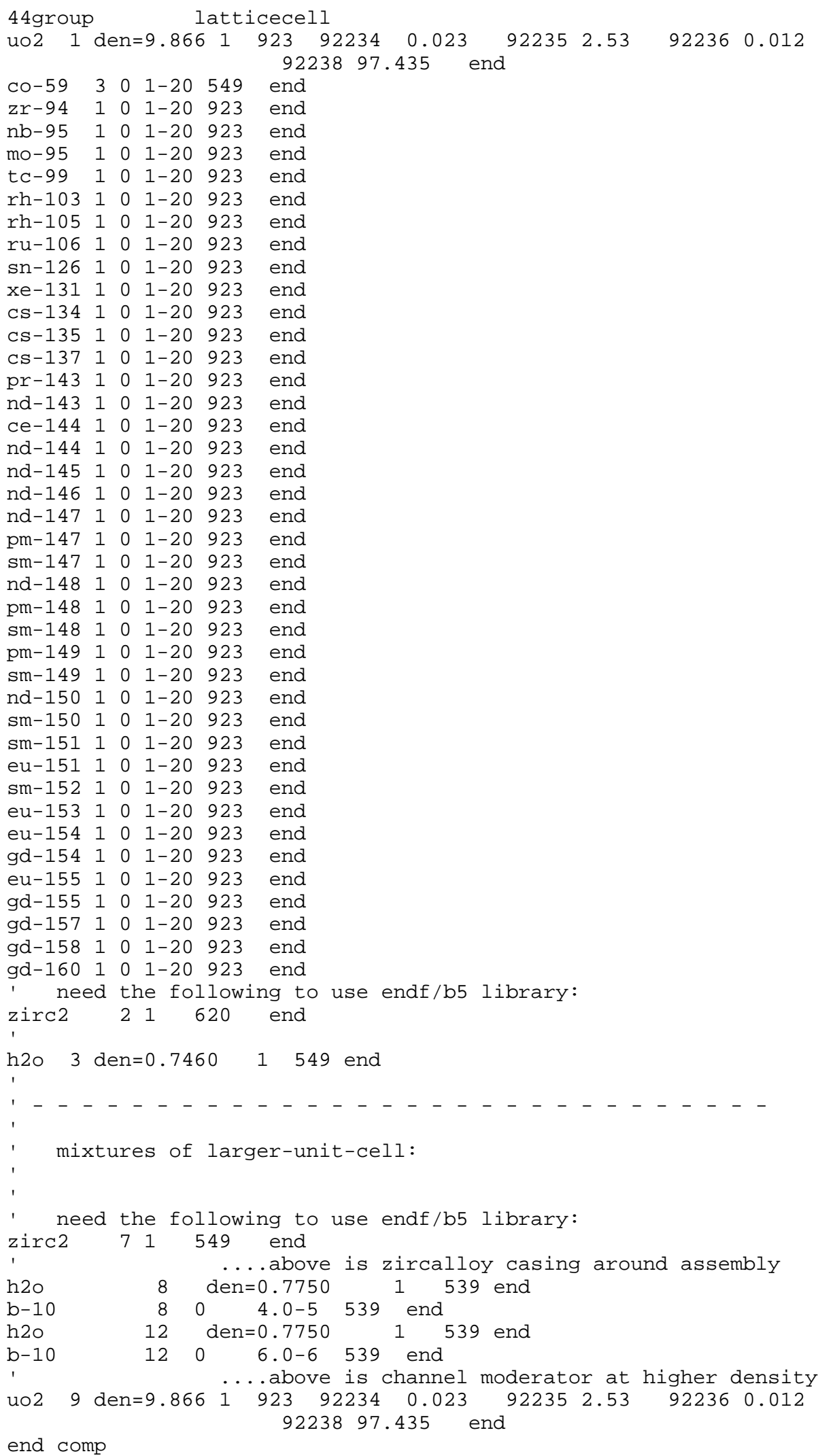




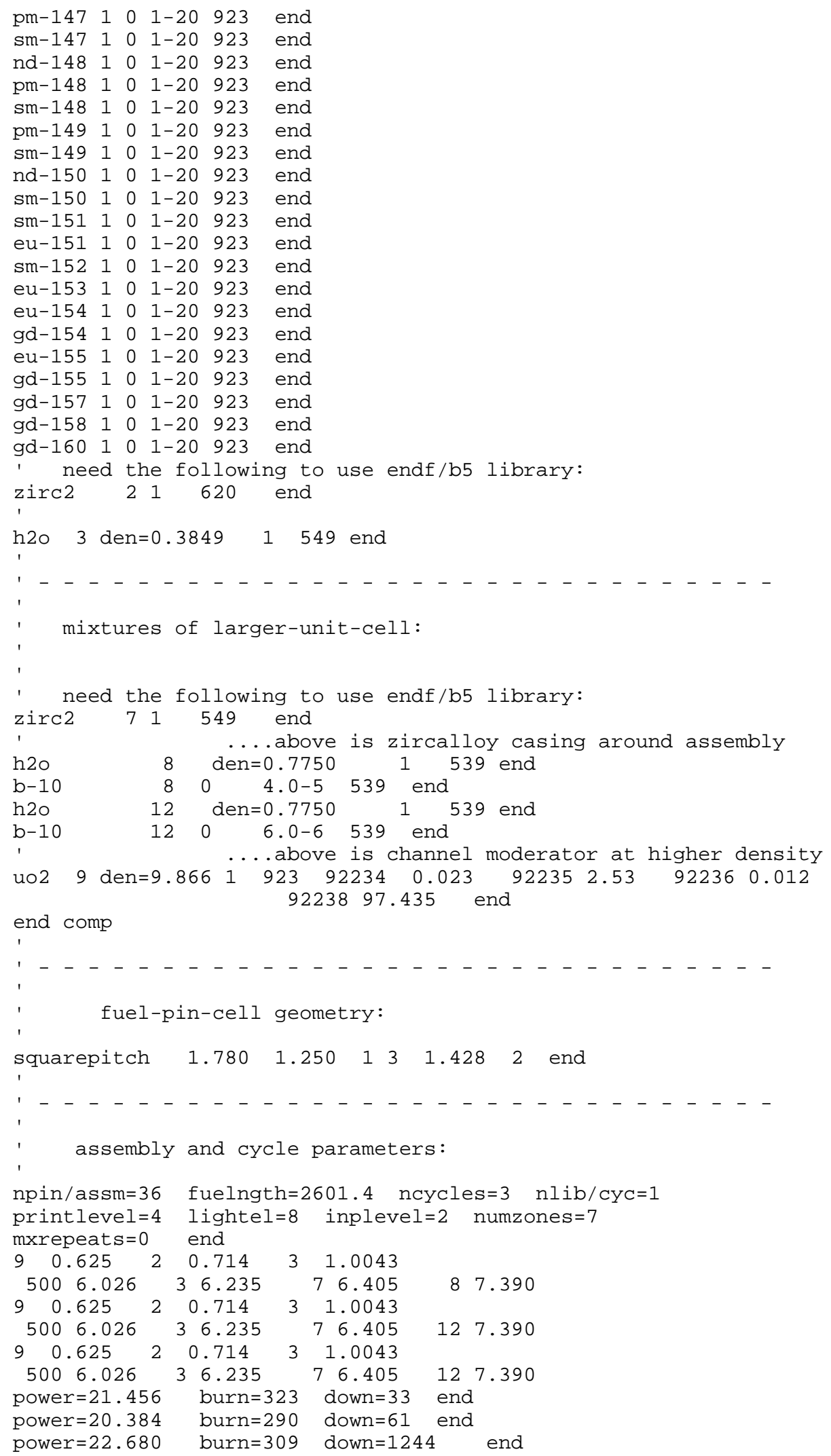




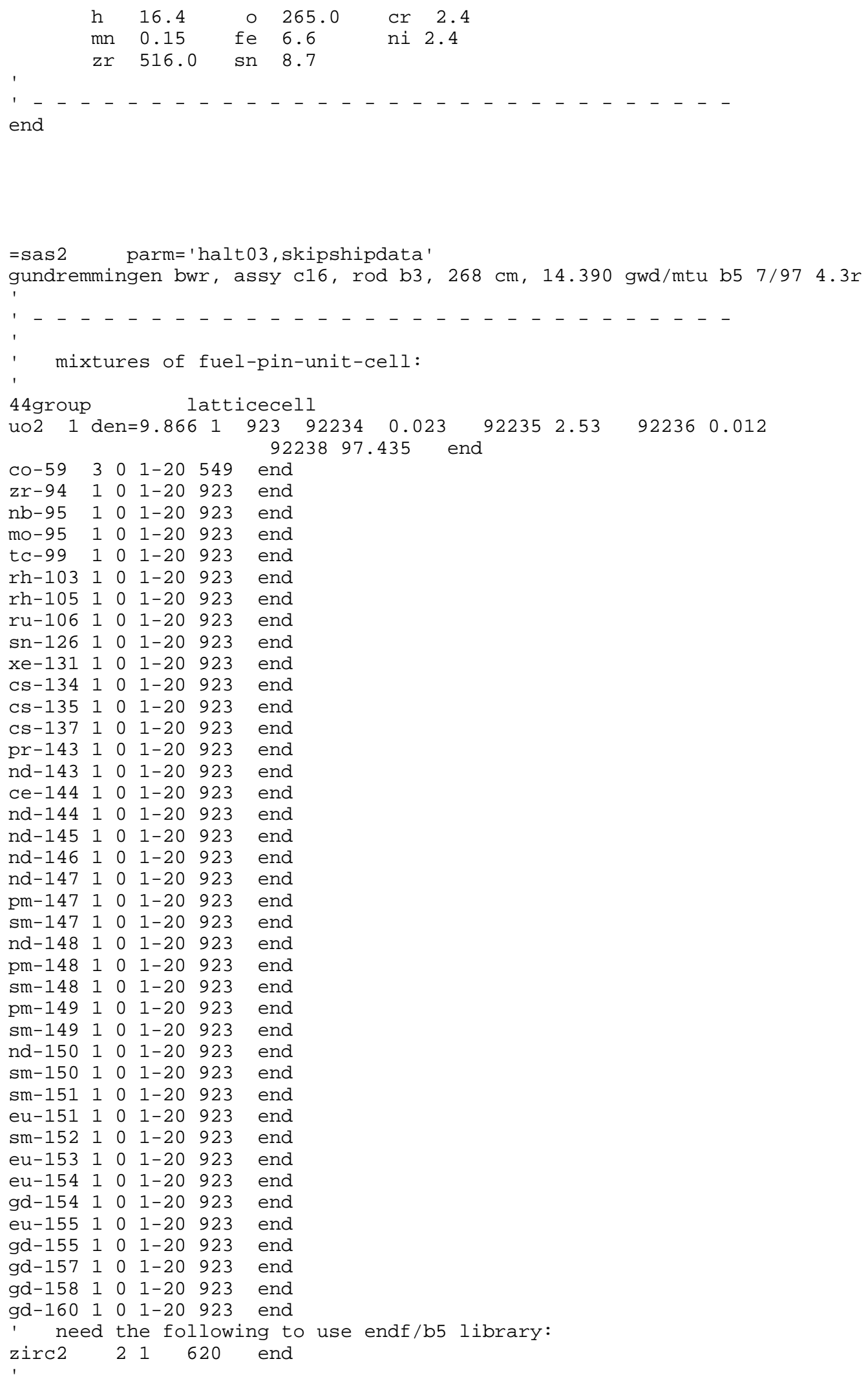




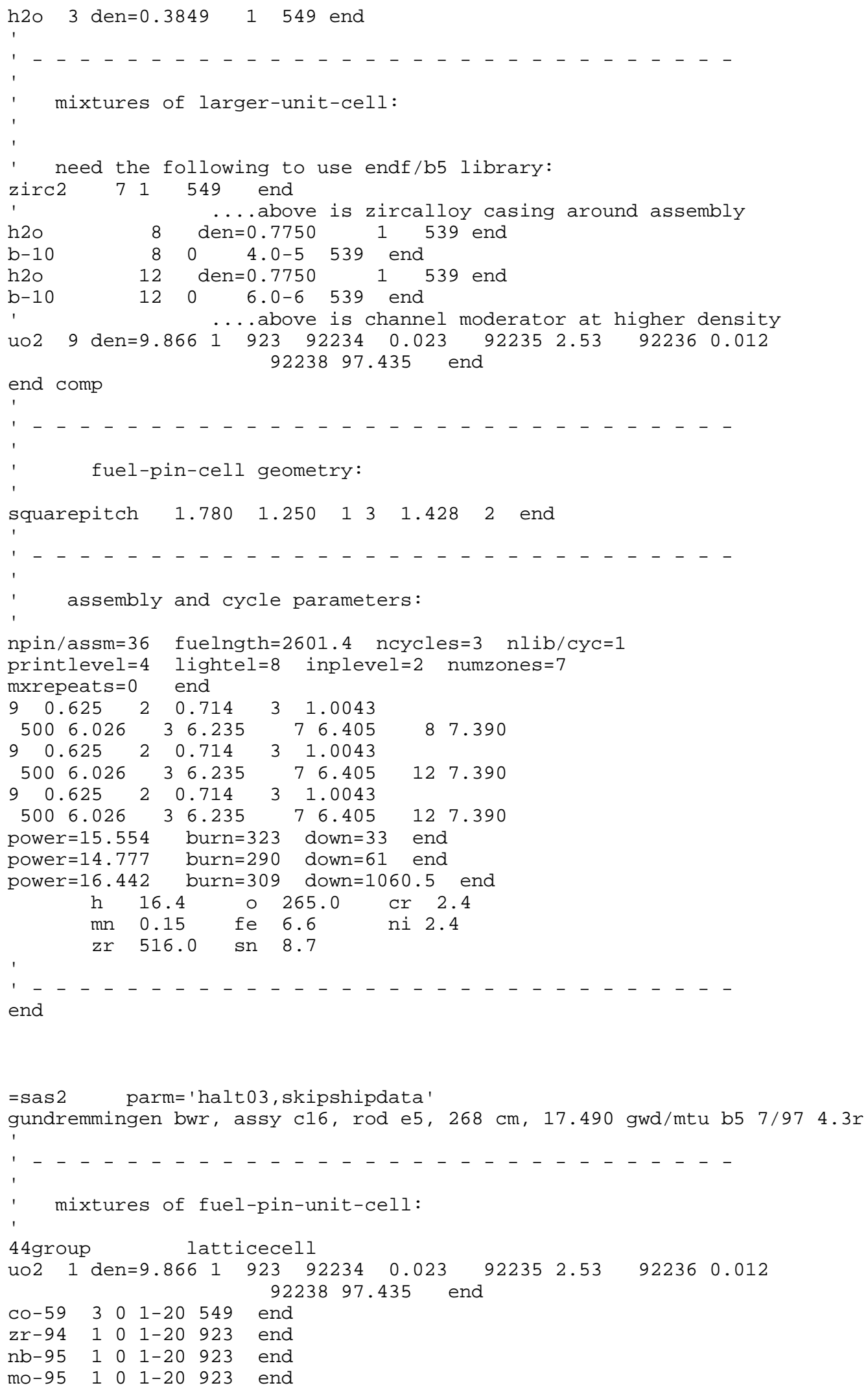




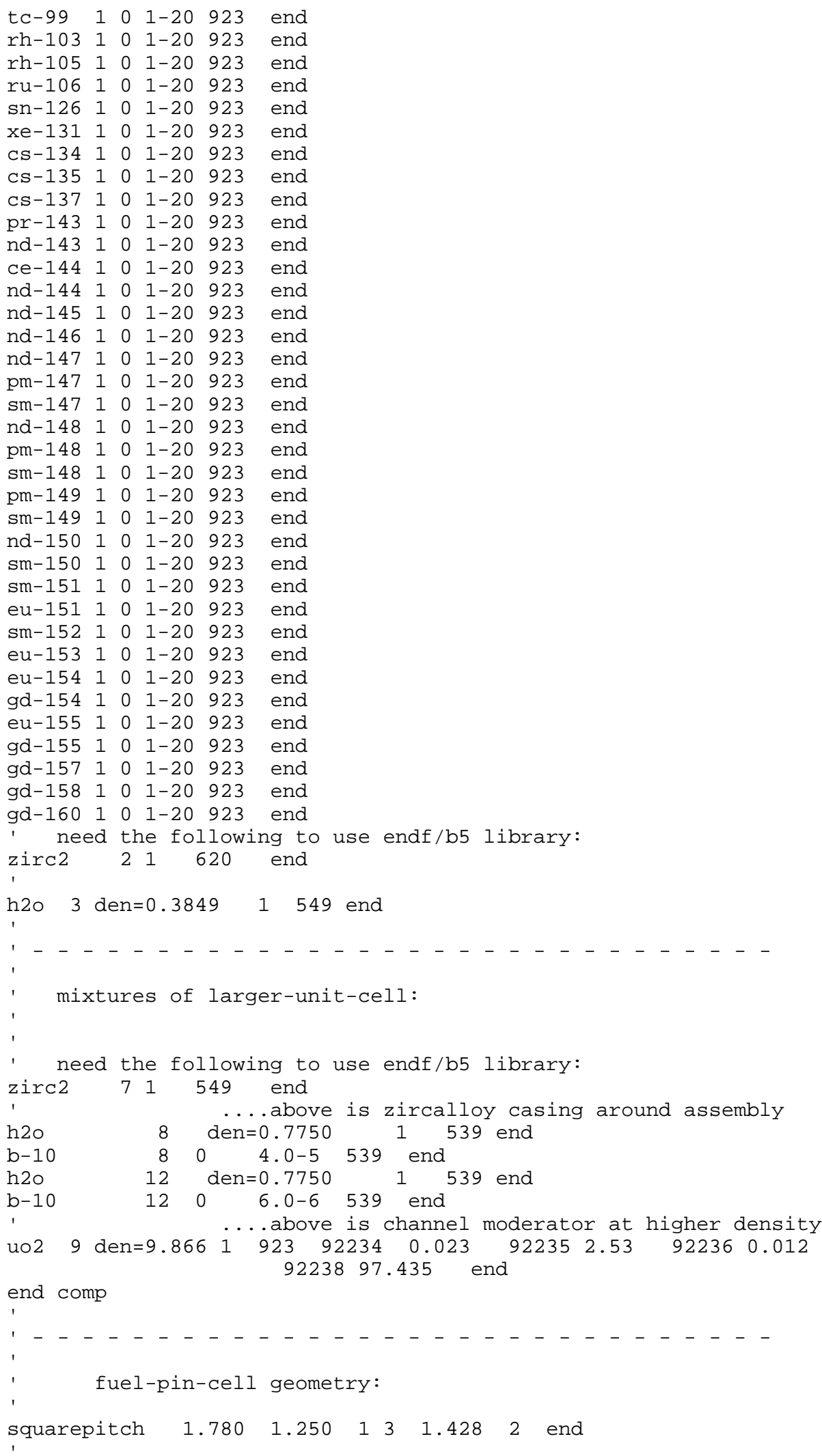




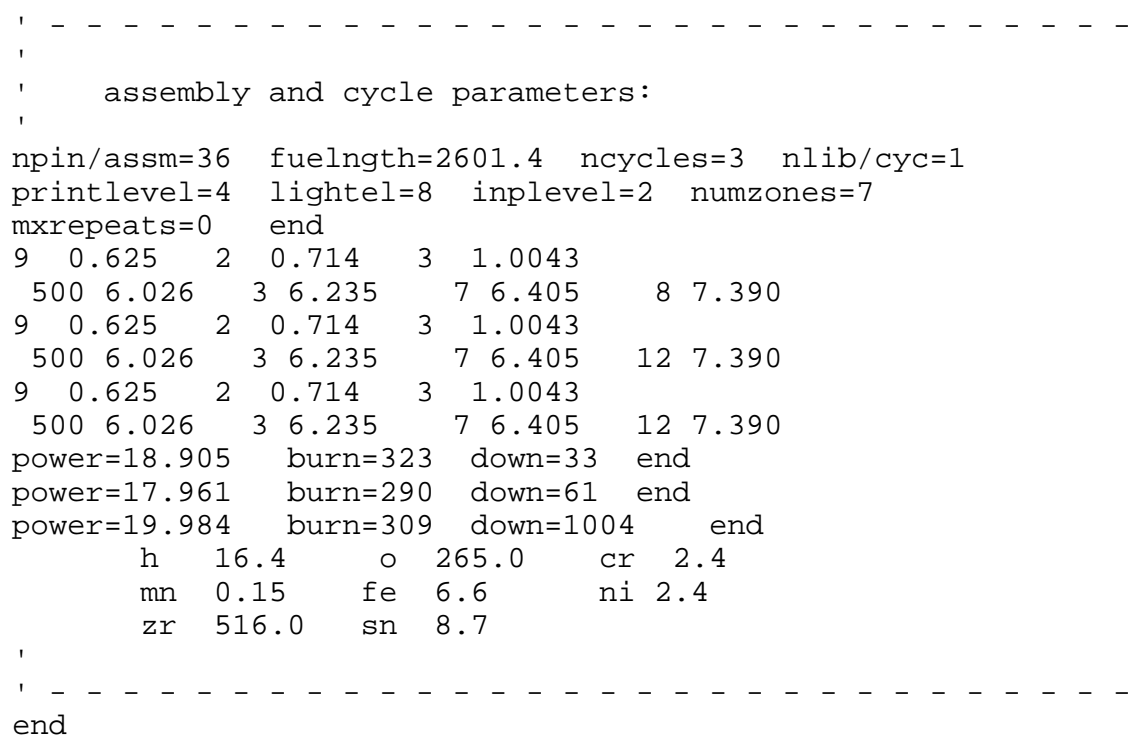




\section{APPENDIX D}

\section{INPUT LISTINGS FOR JPDR BWR SAS2H DEPLETION CALCULATIONS}

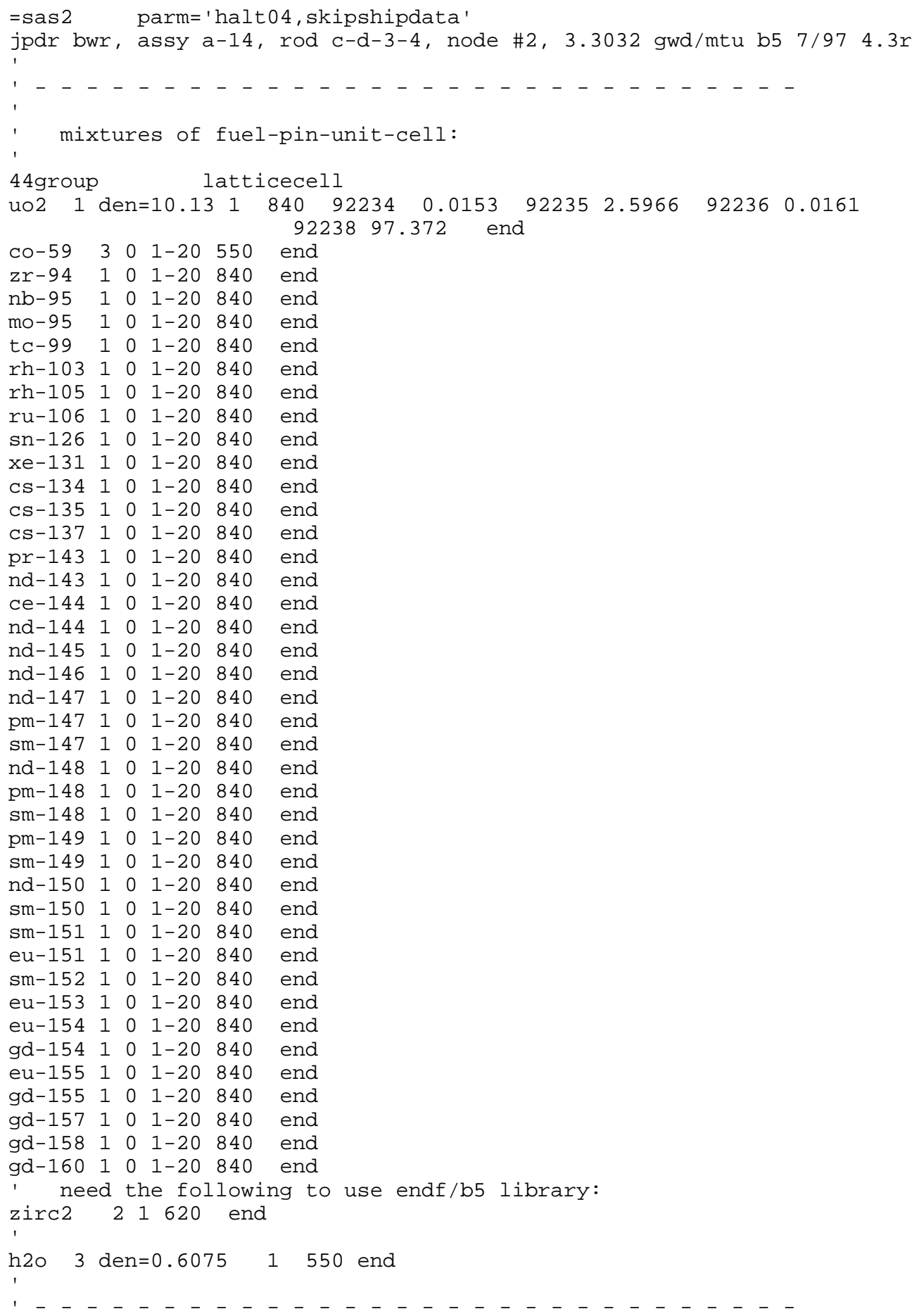




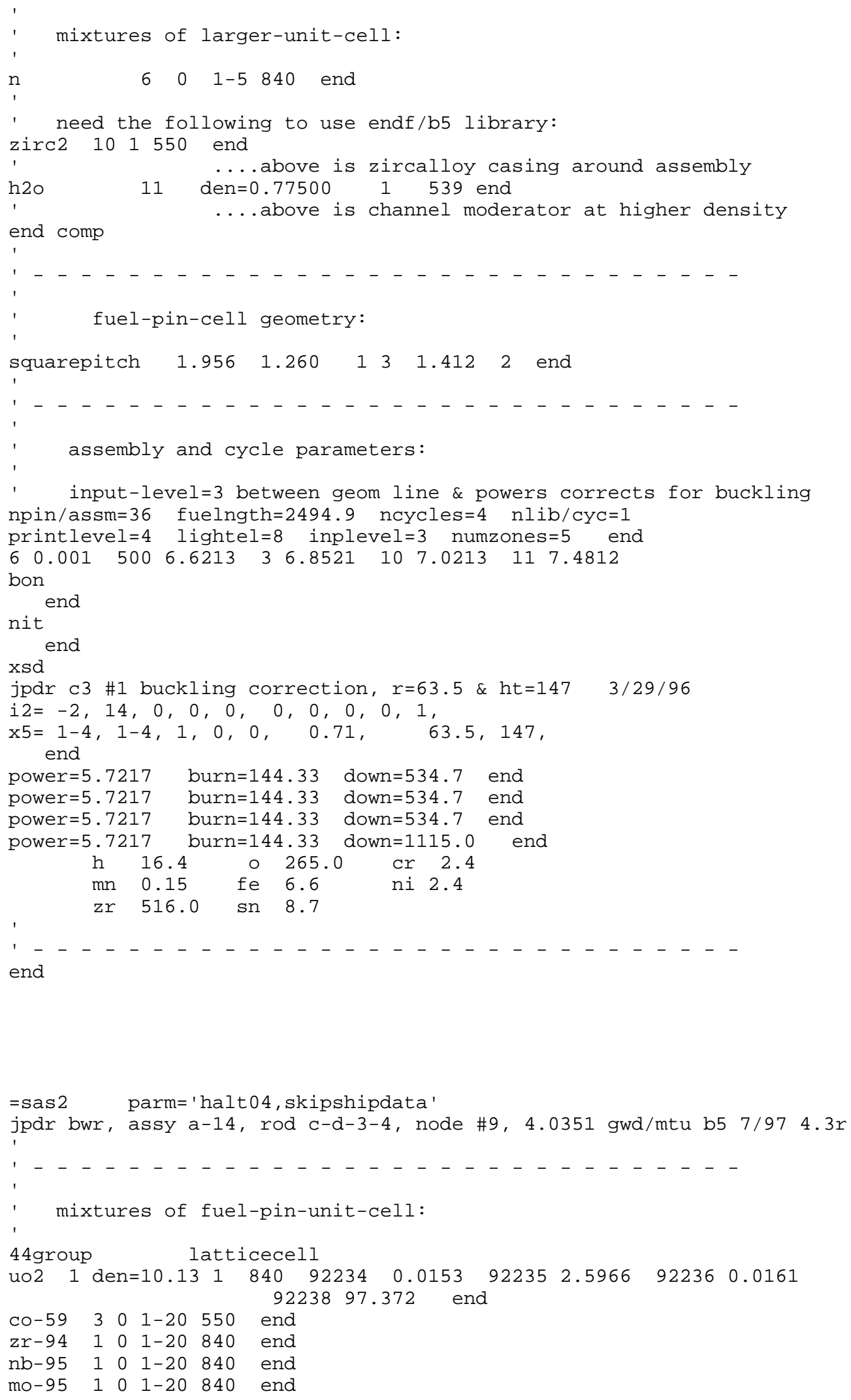




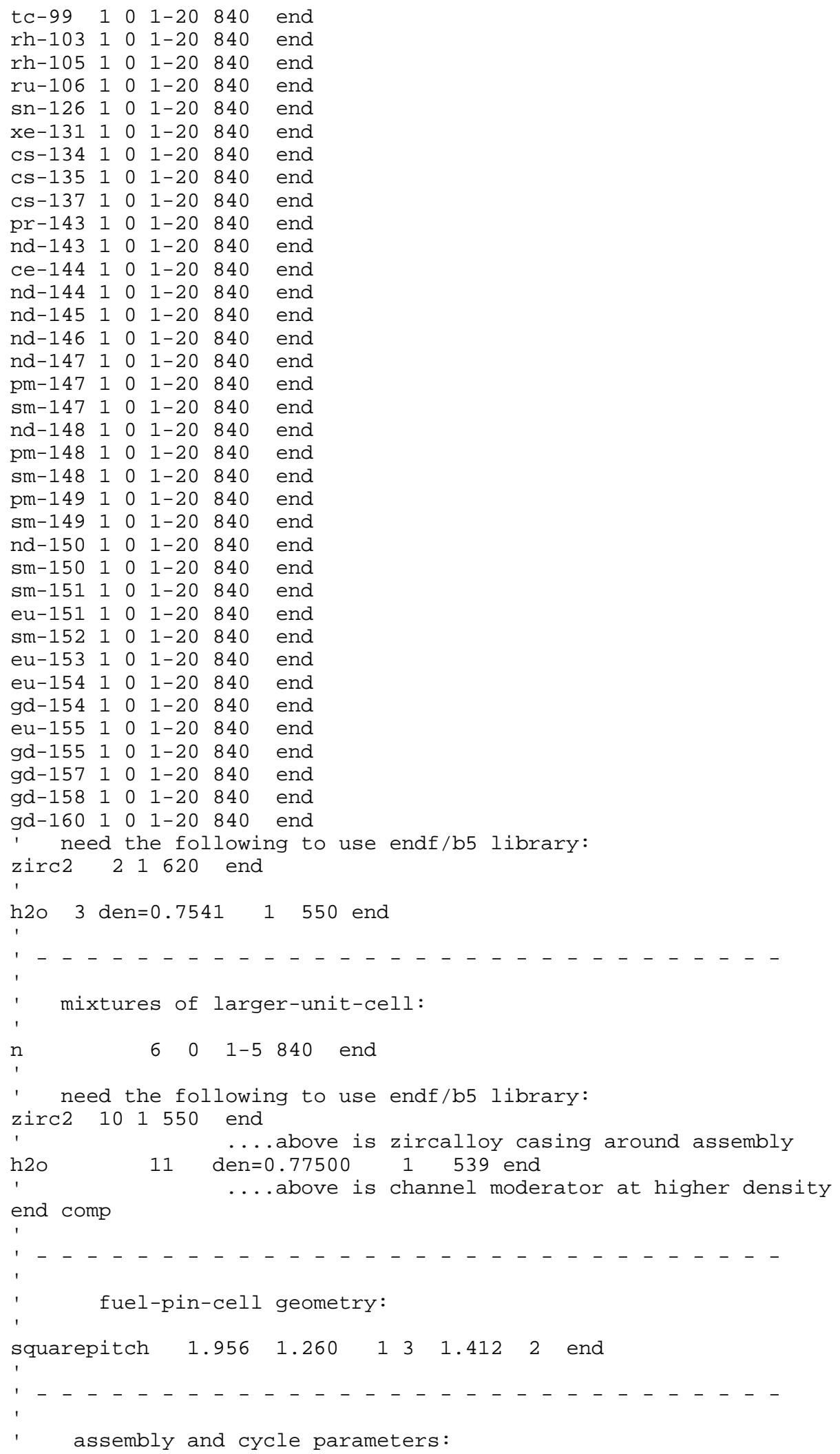




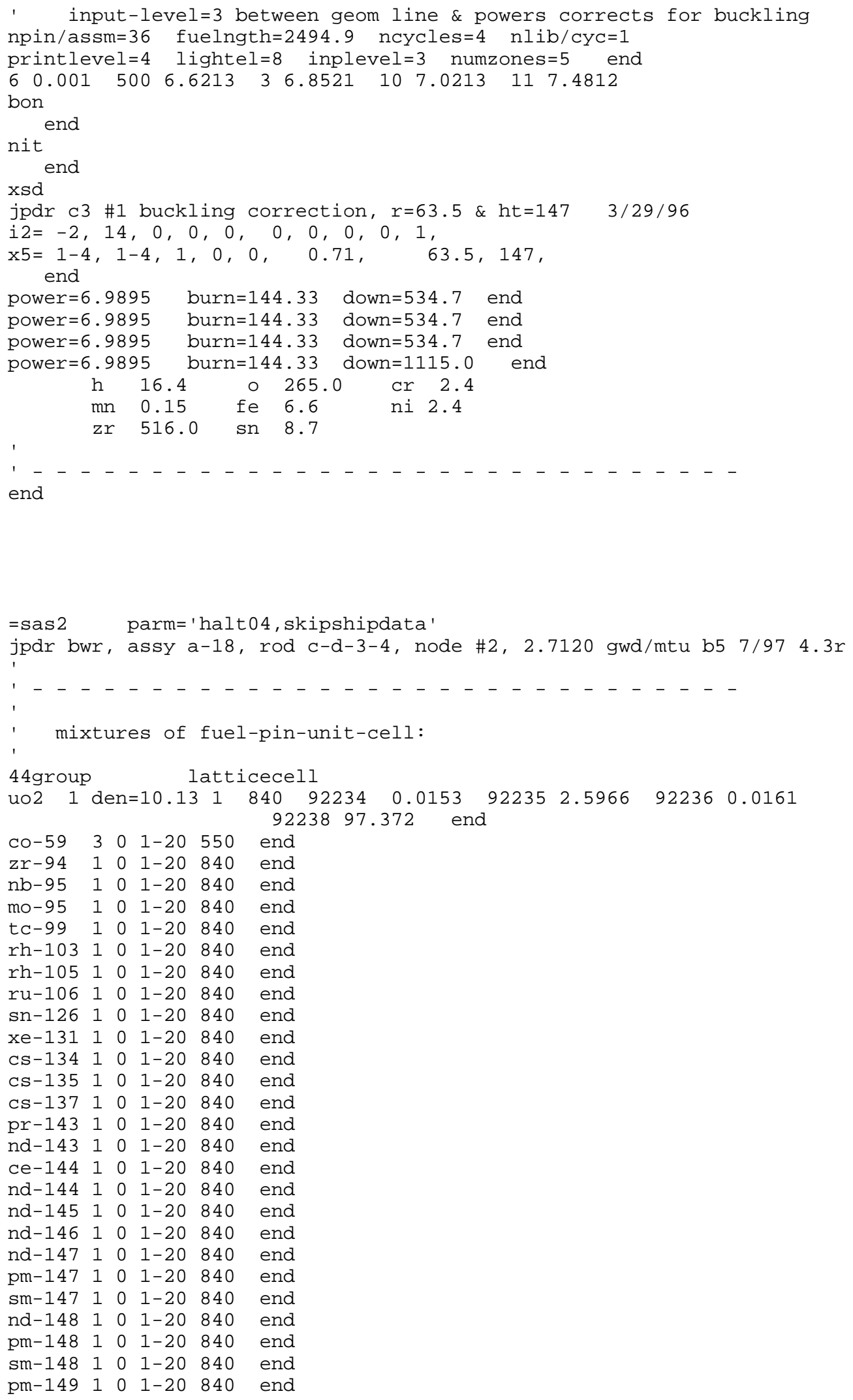




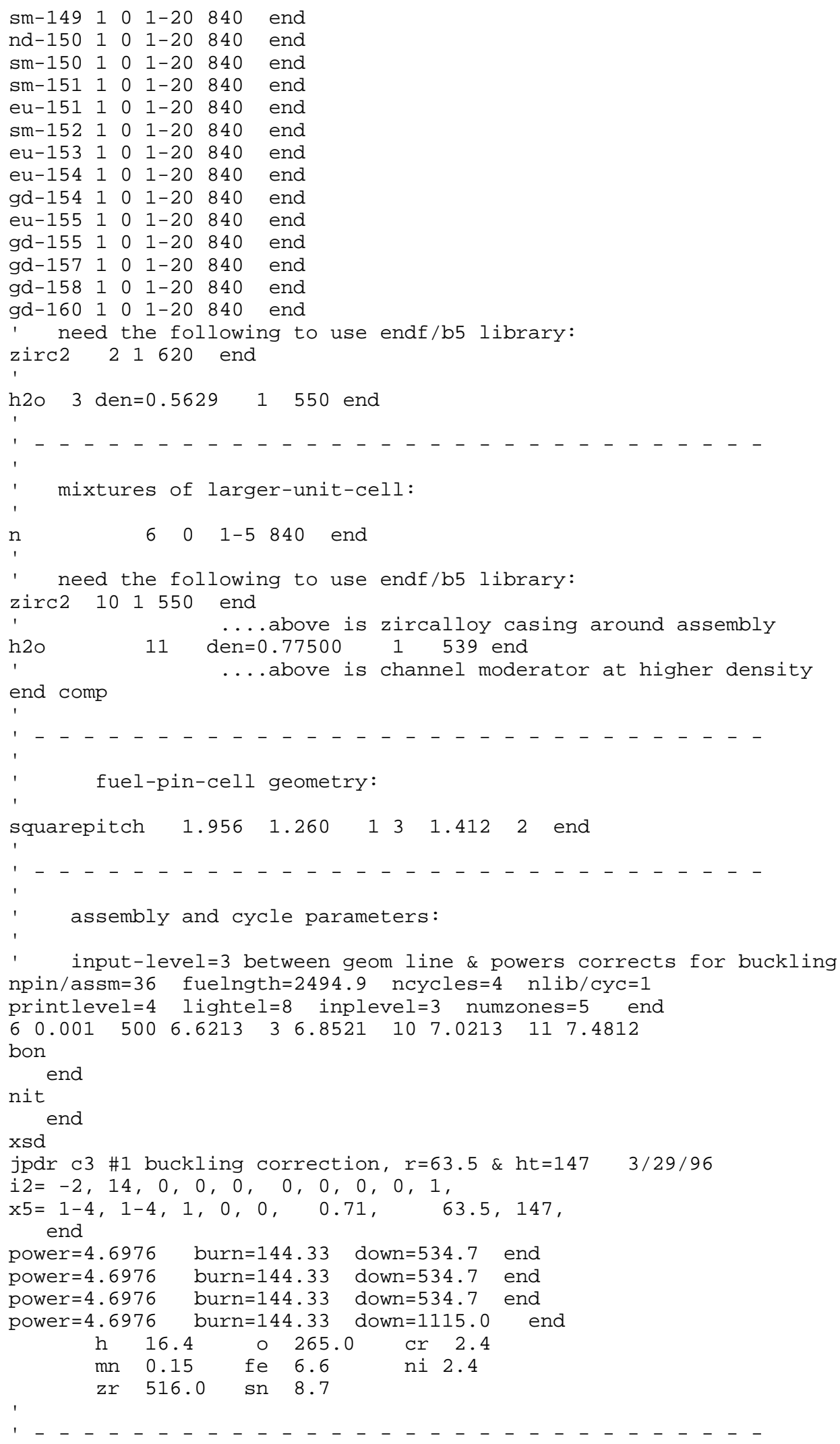




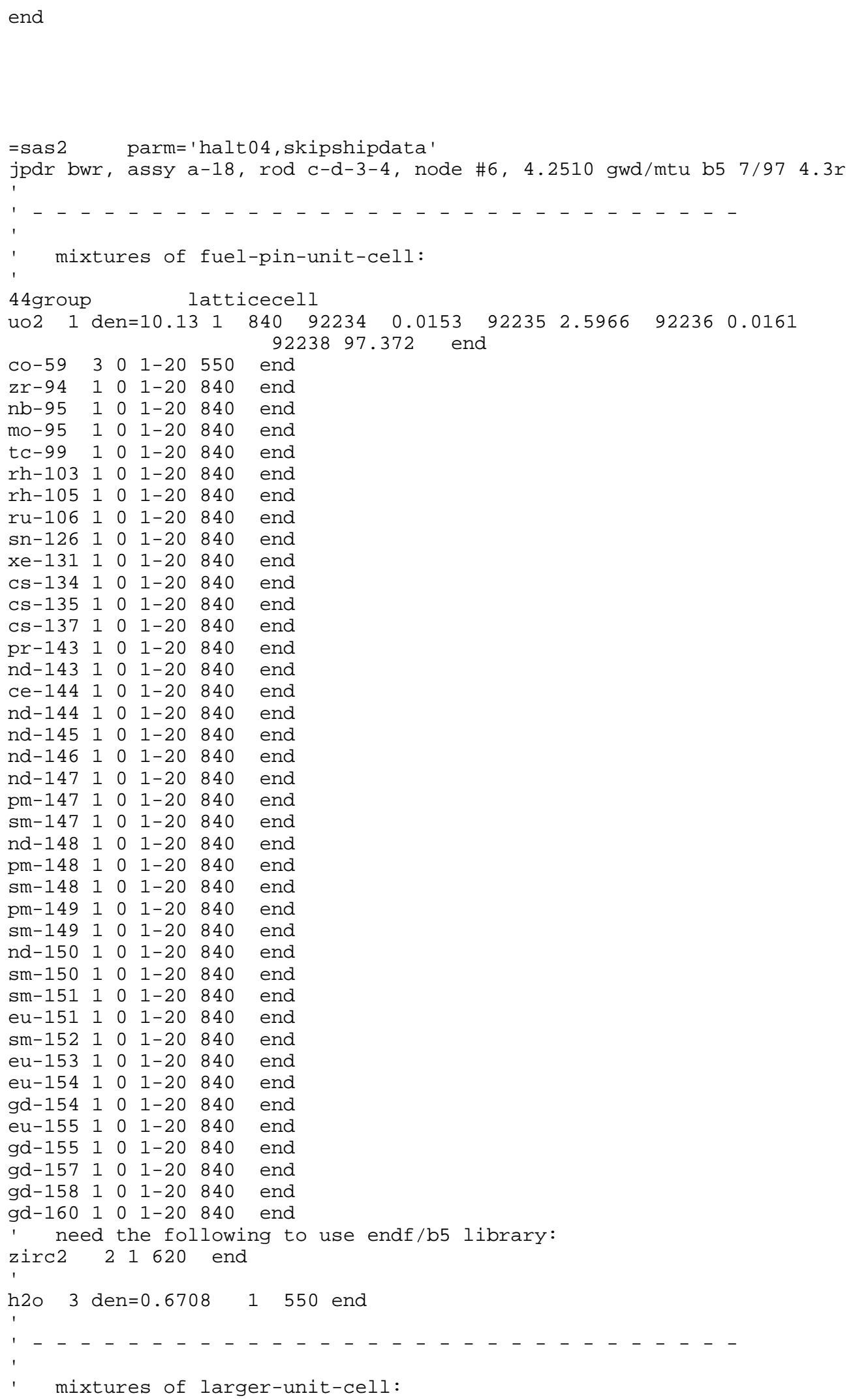




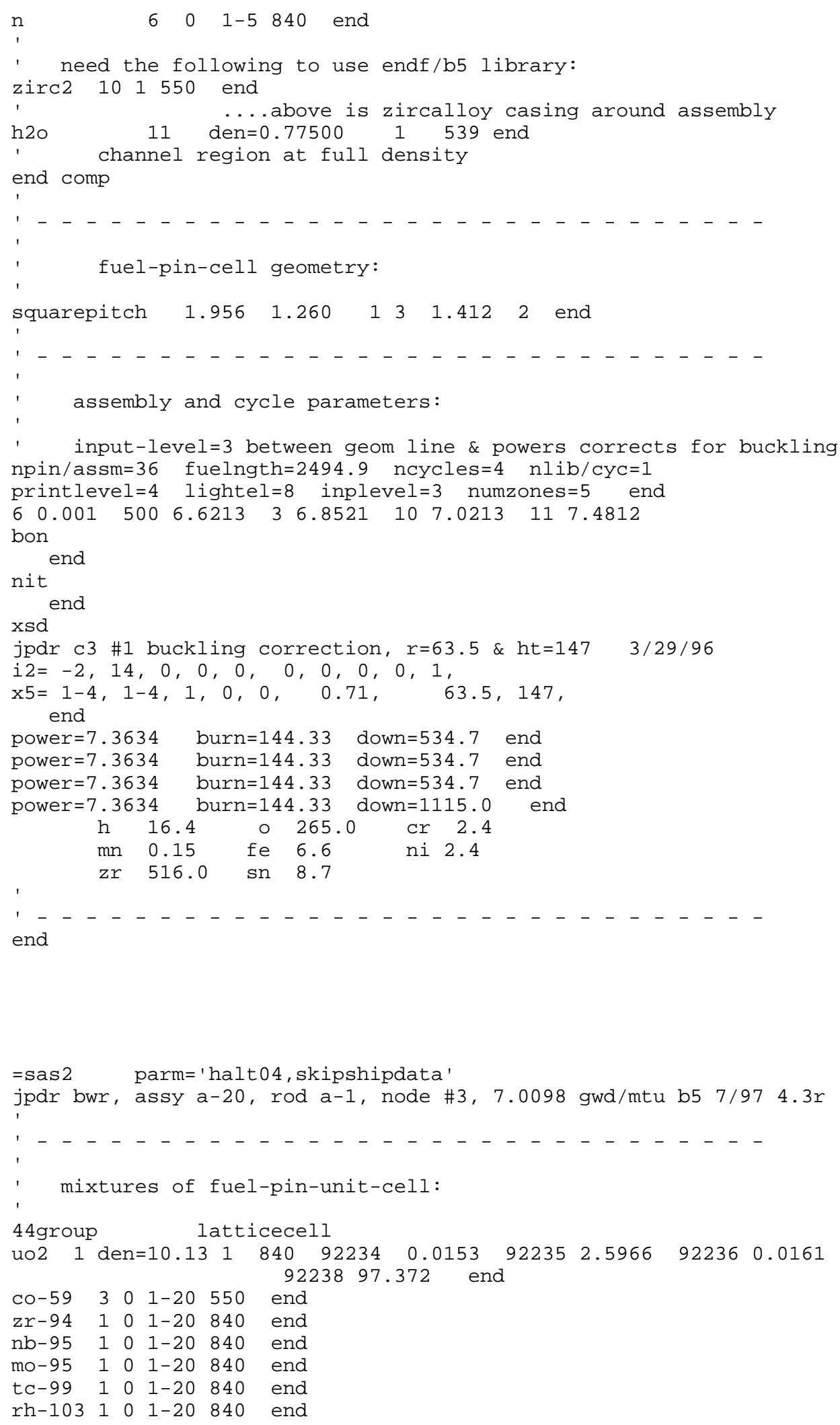




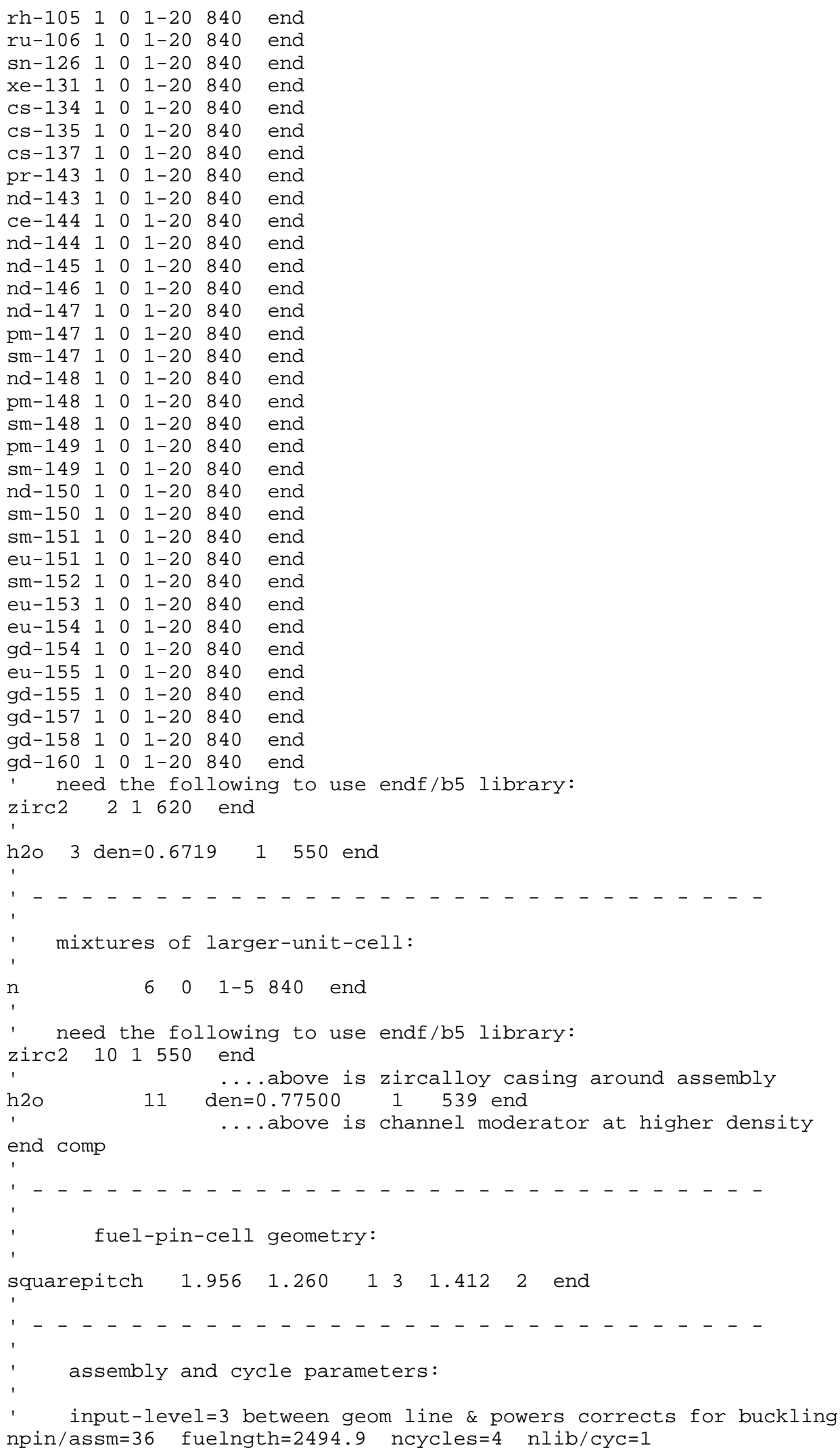




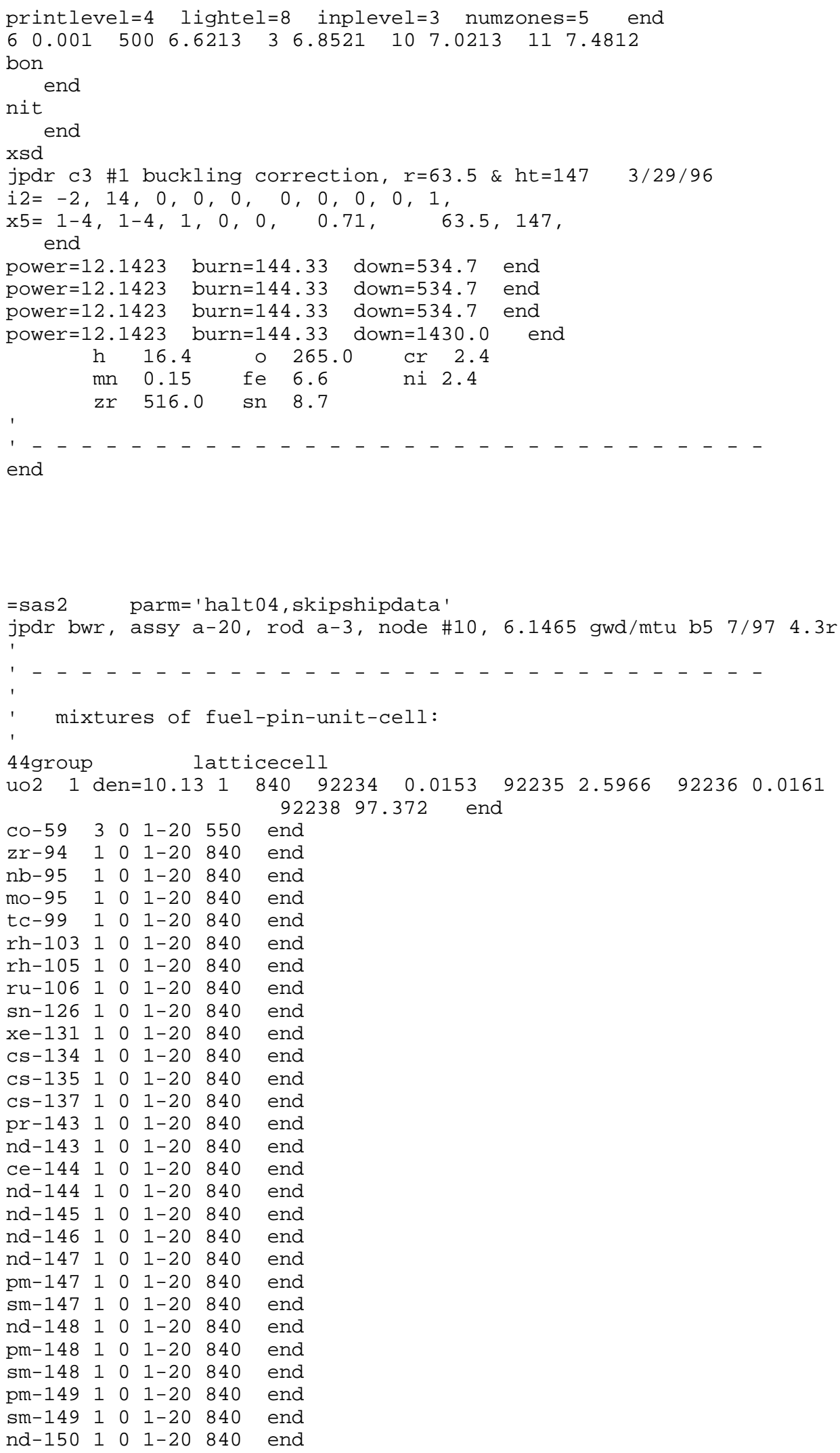




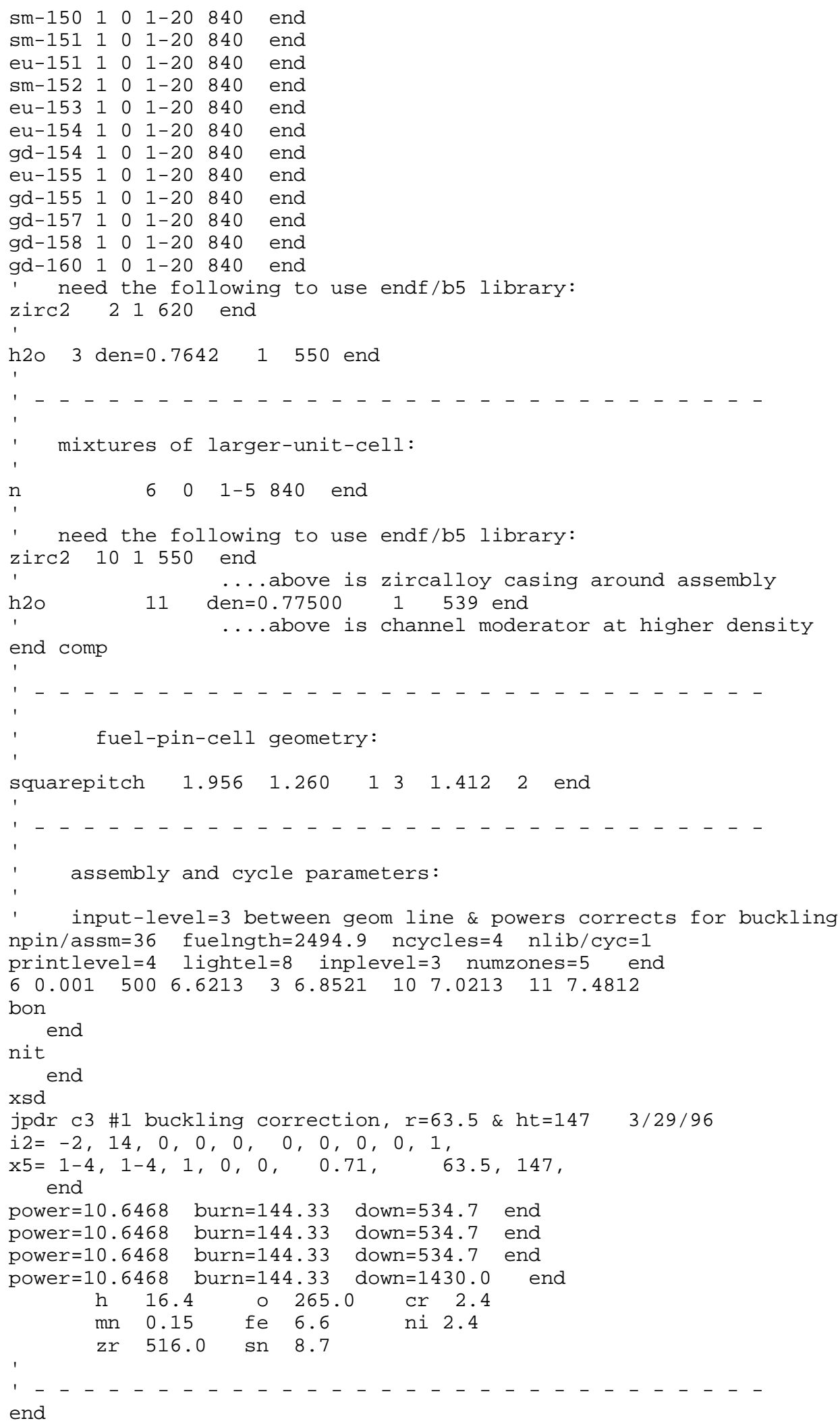




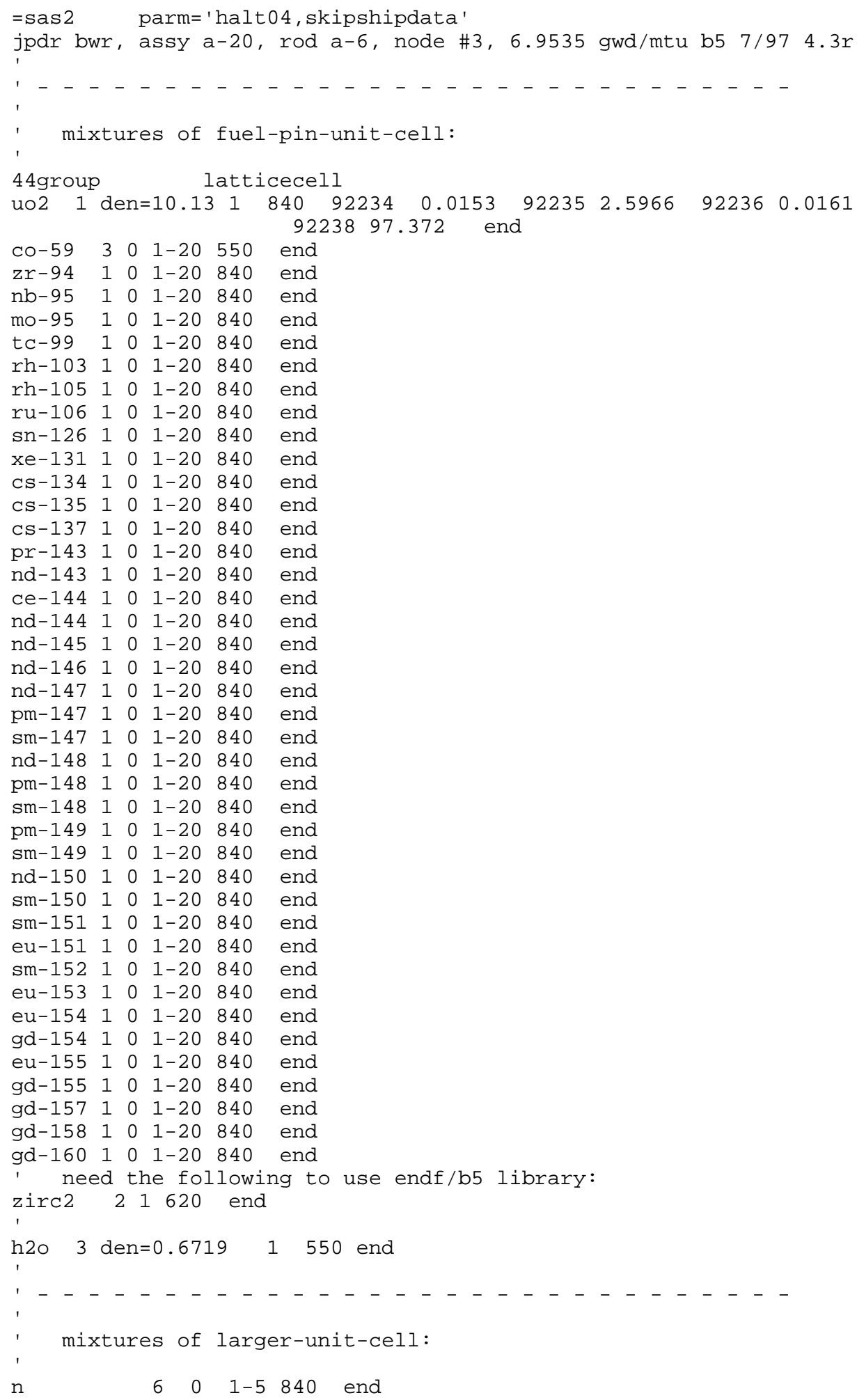




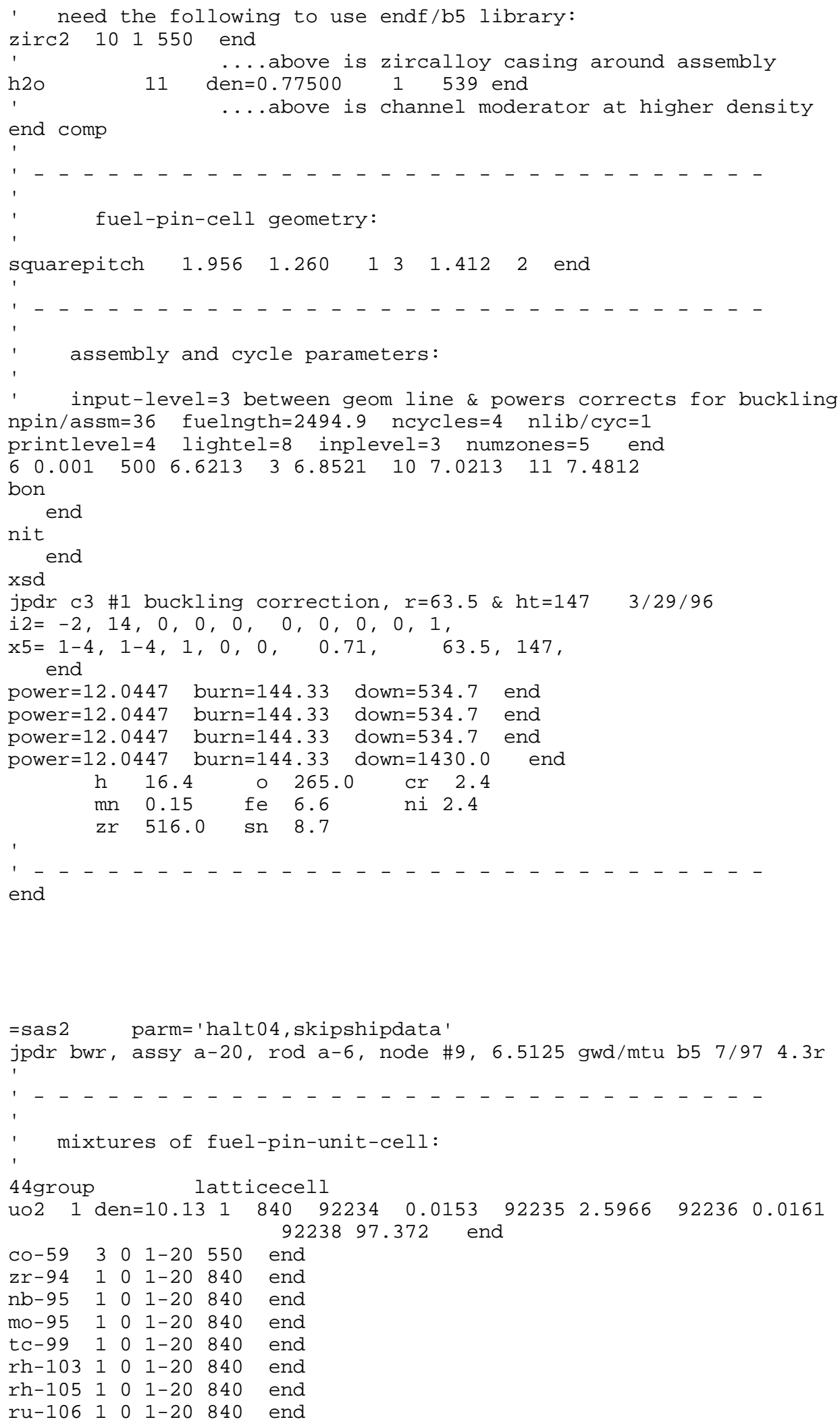




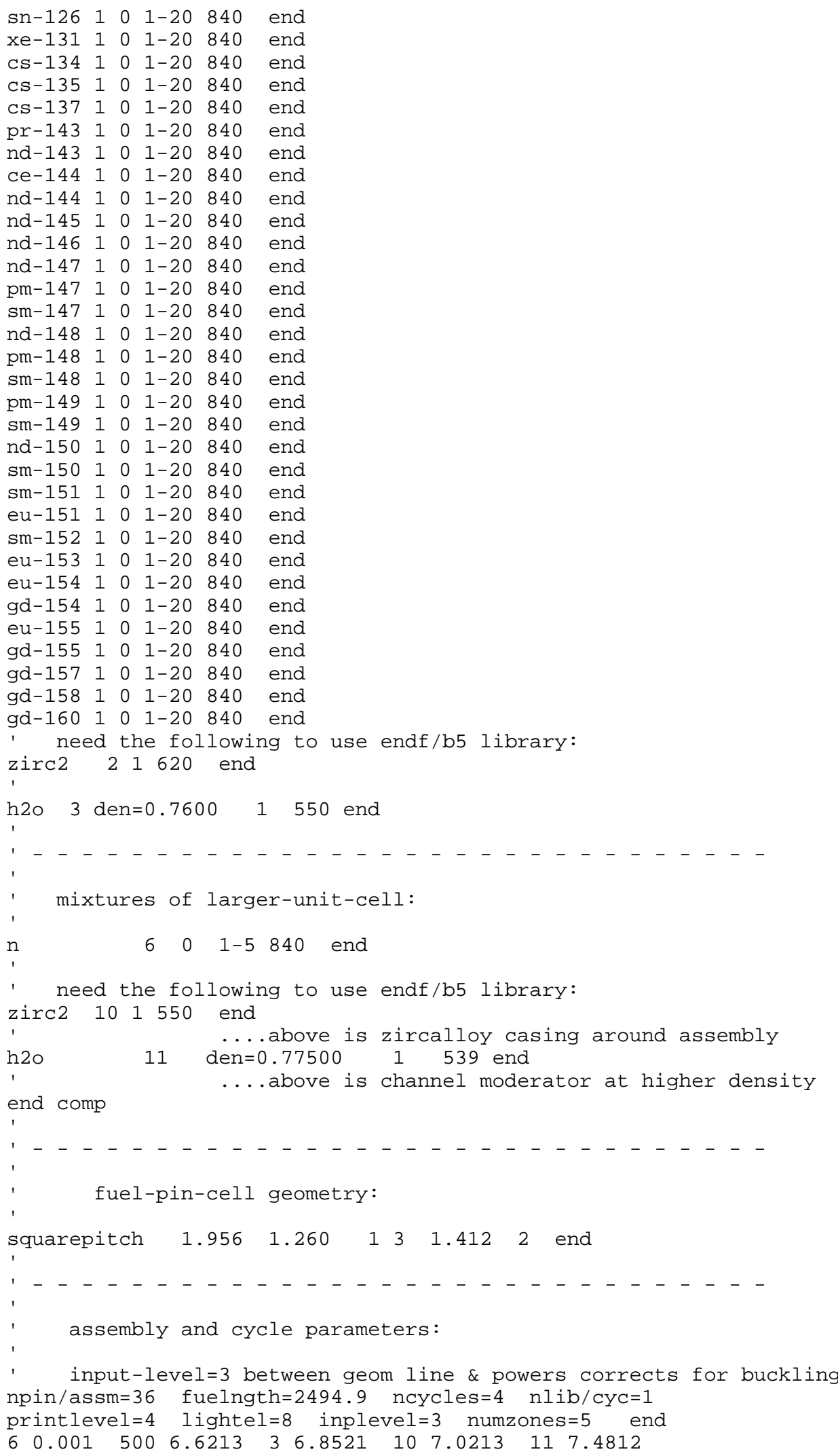




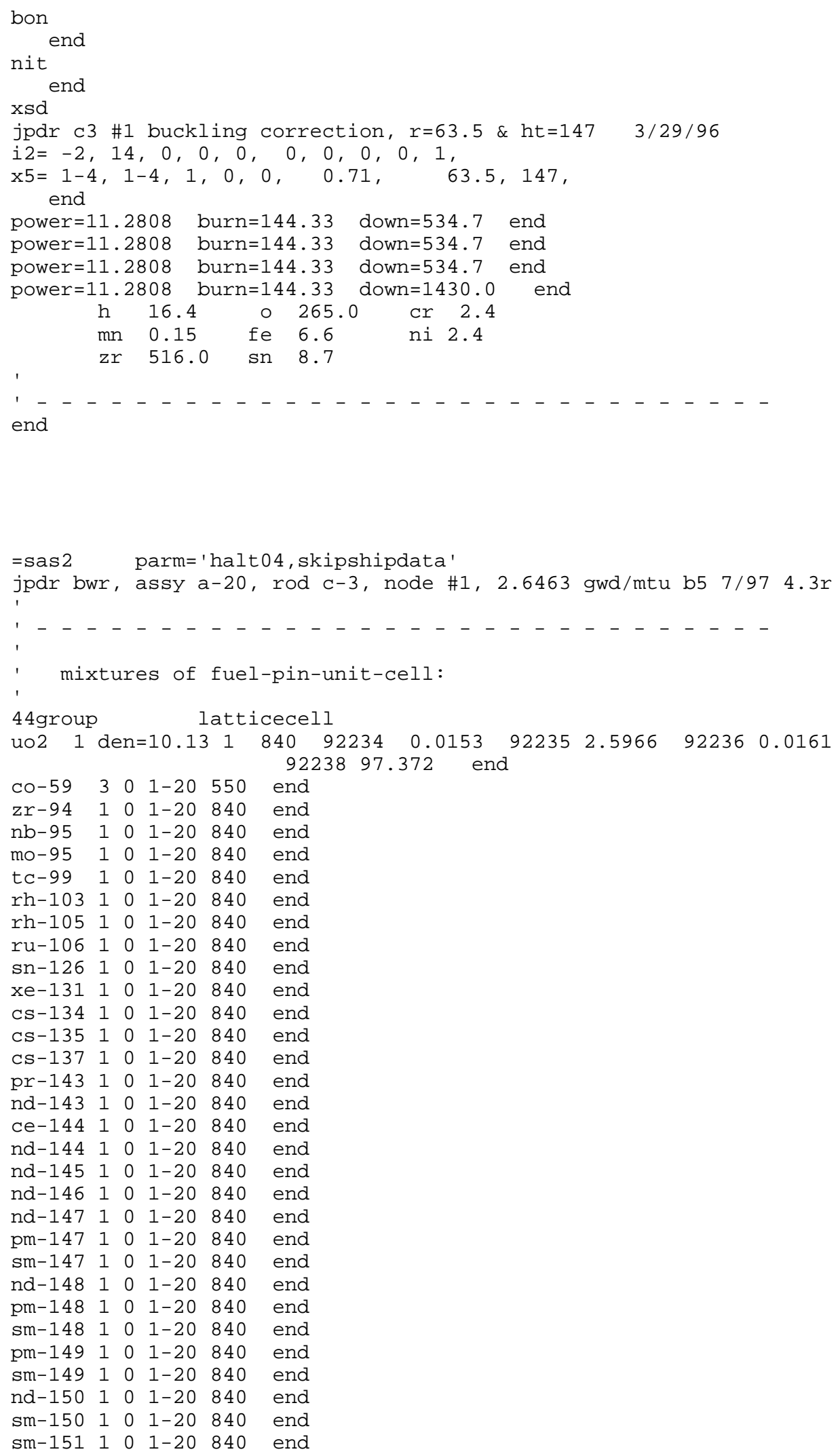




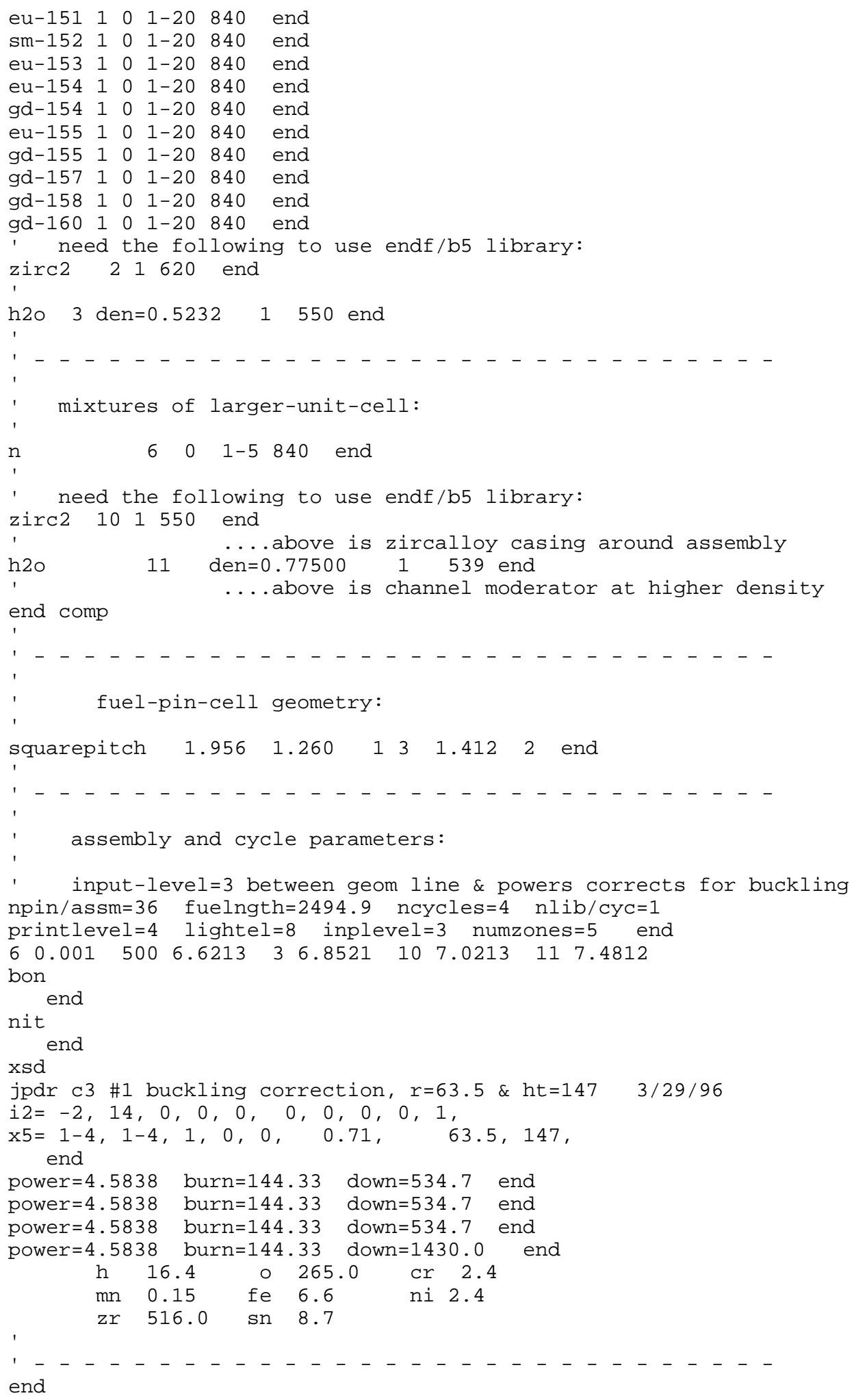




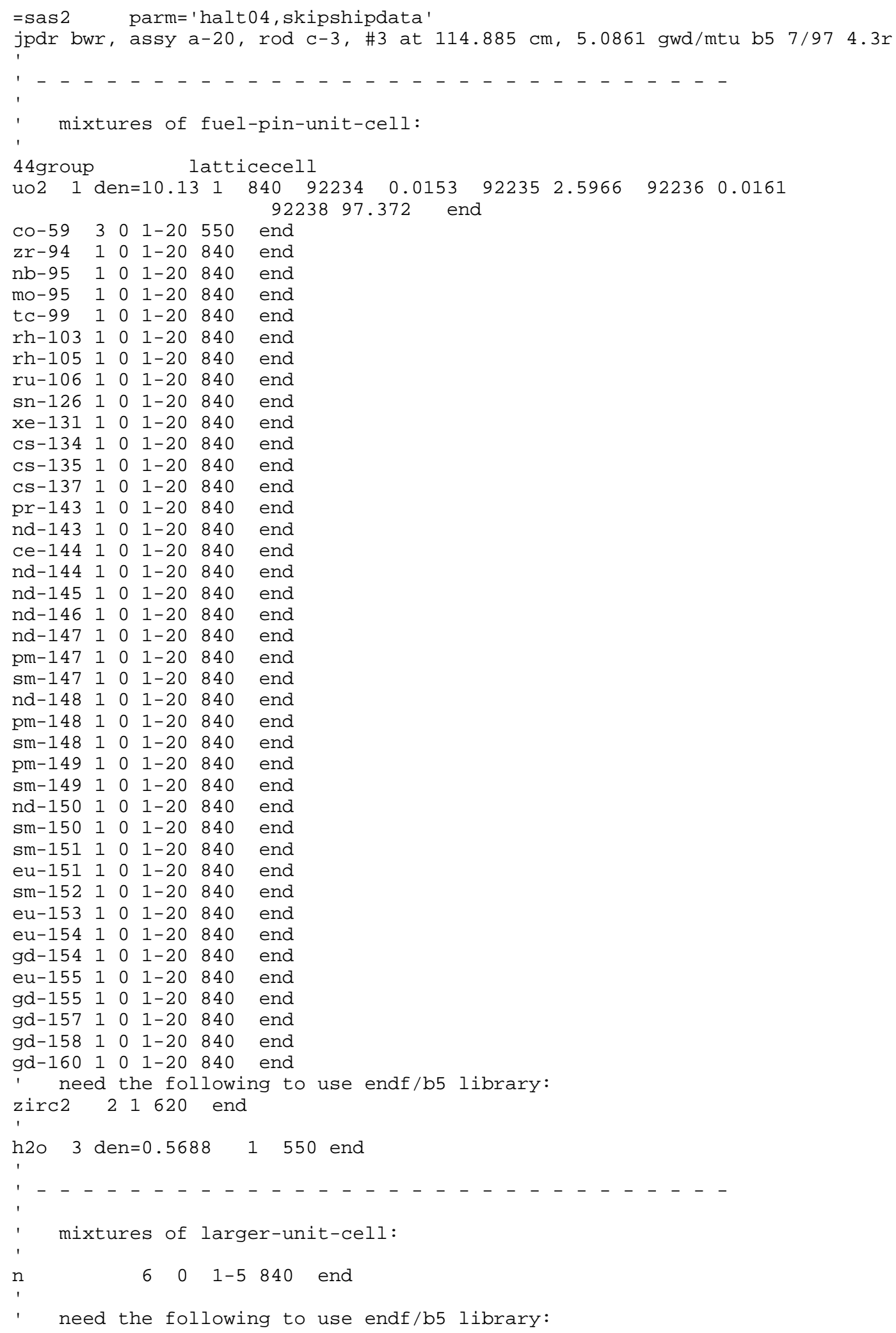




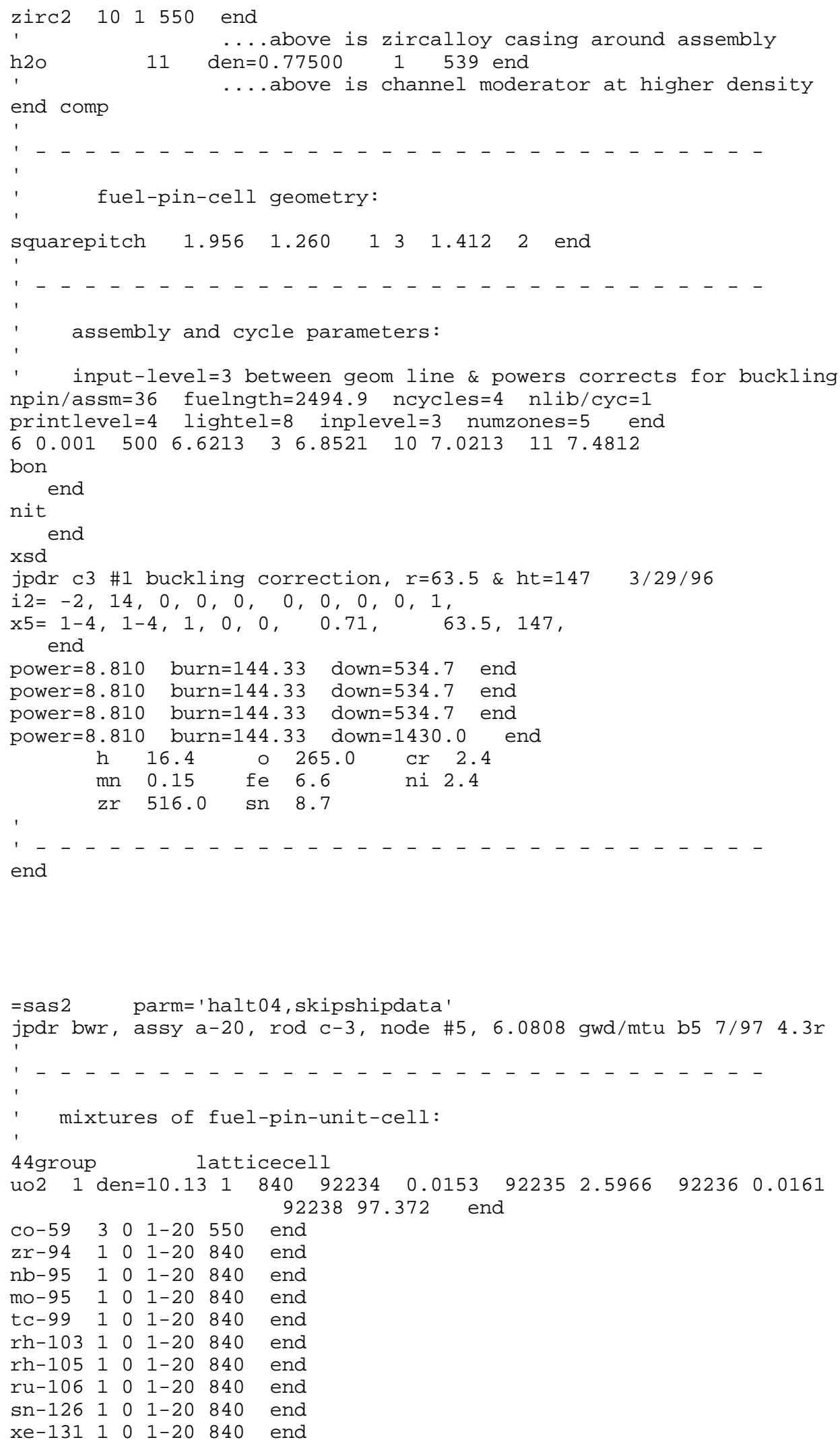




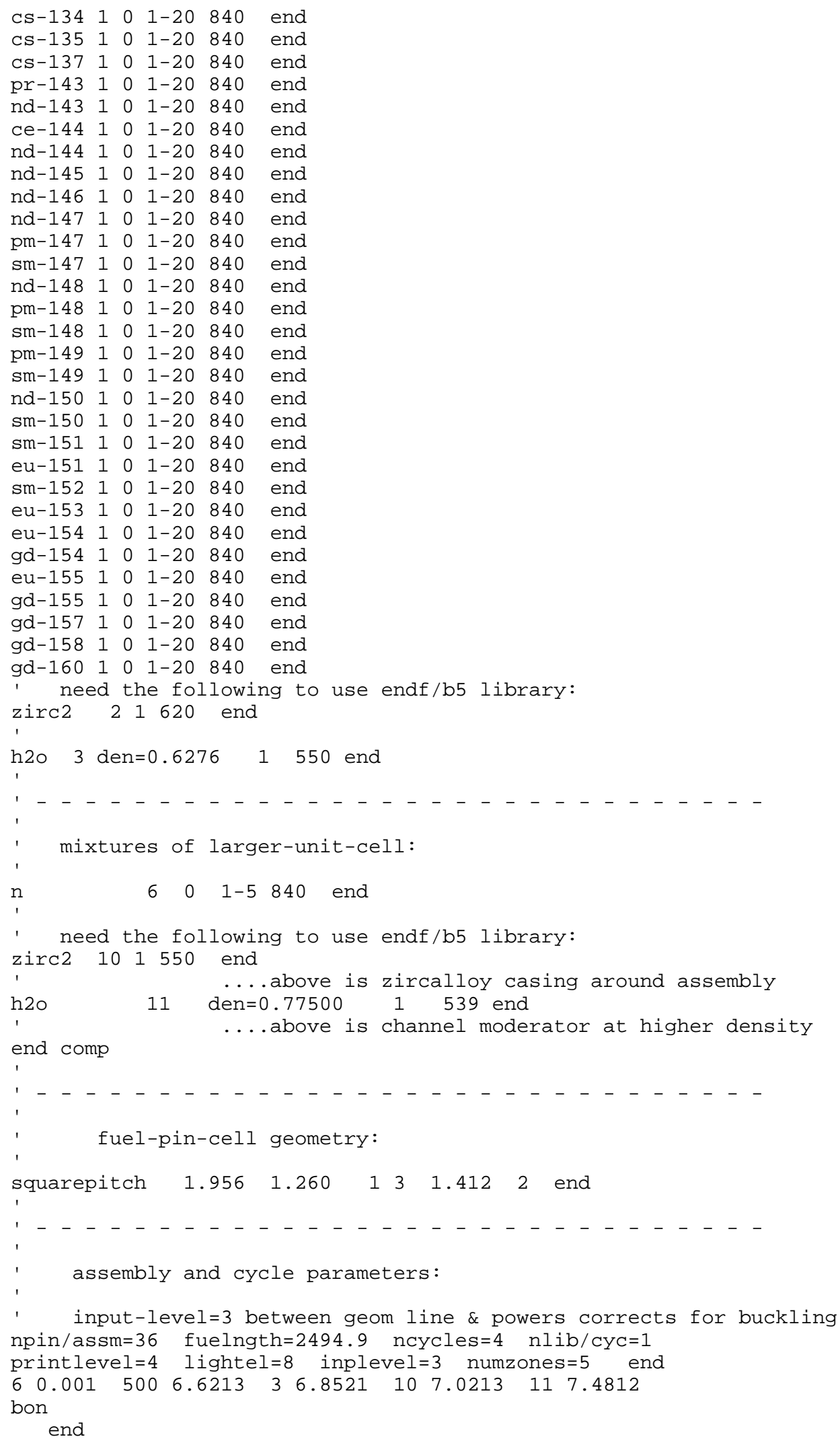




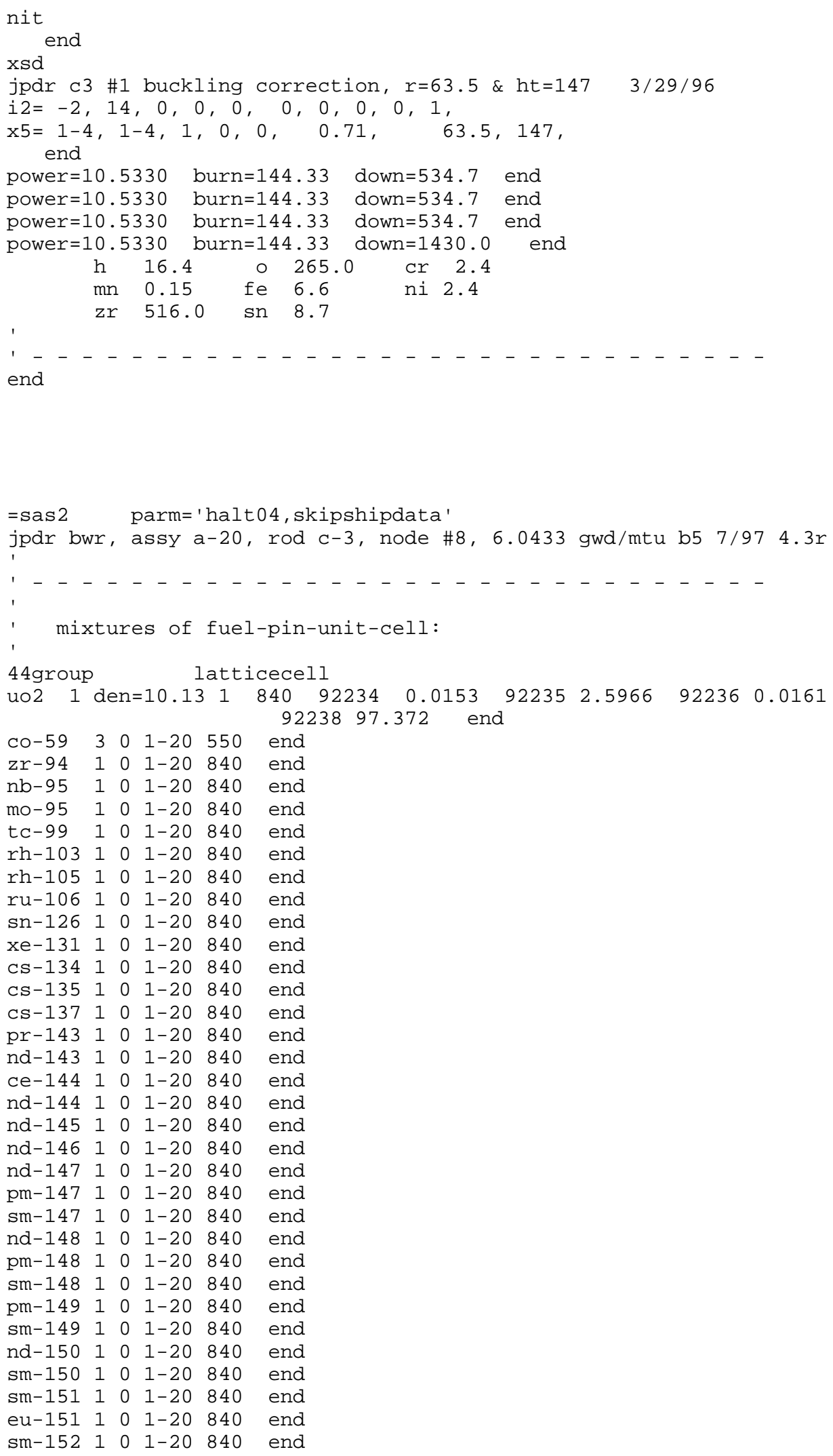




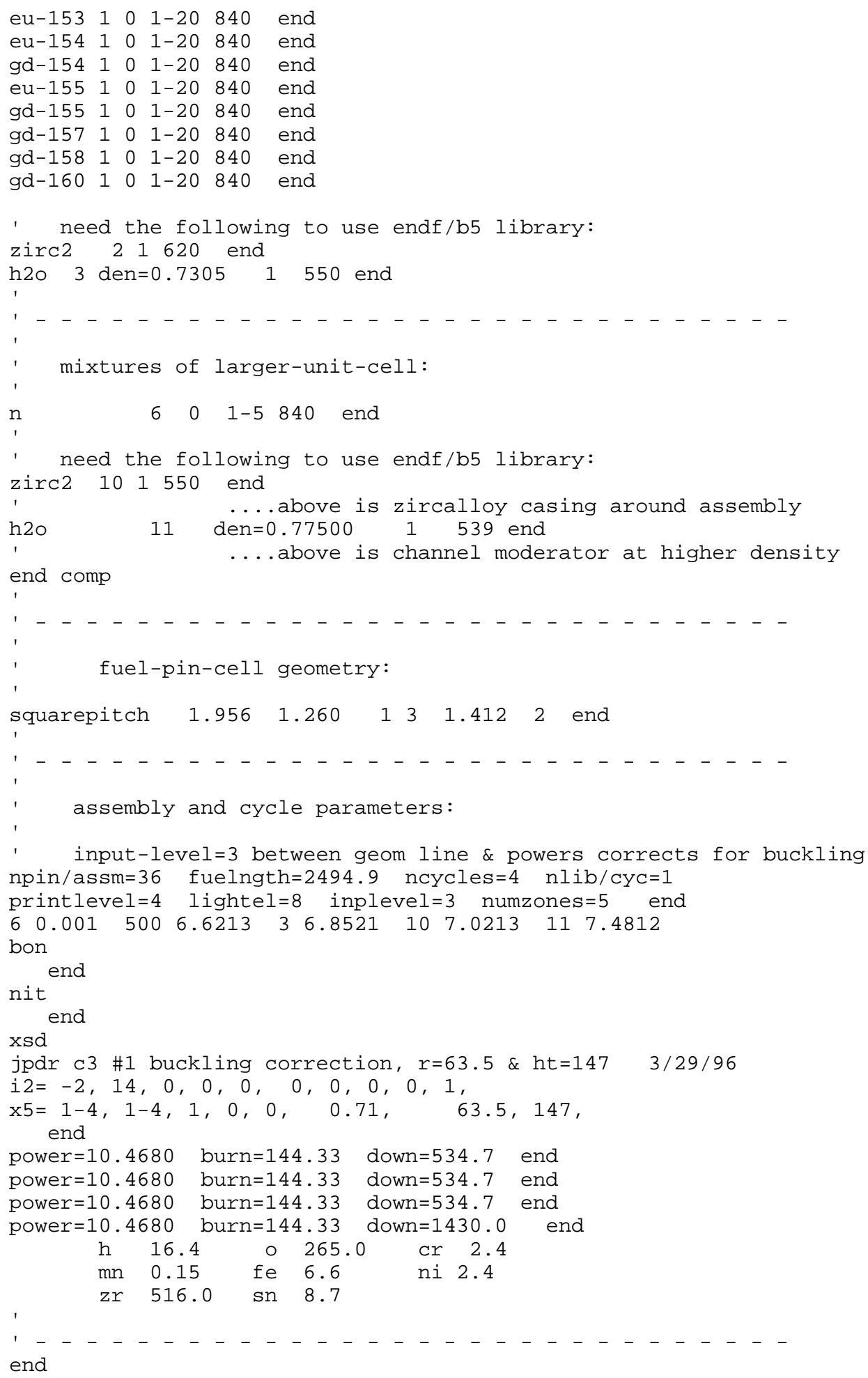




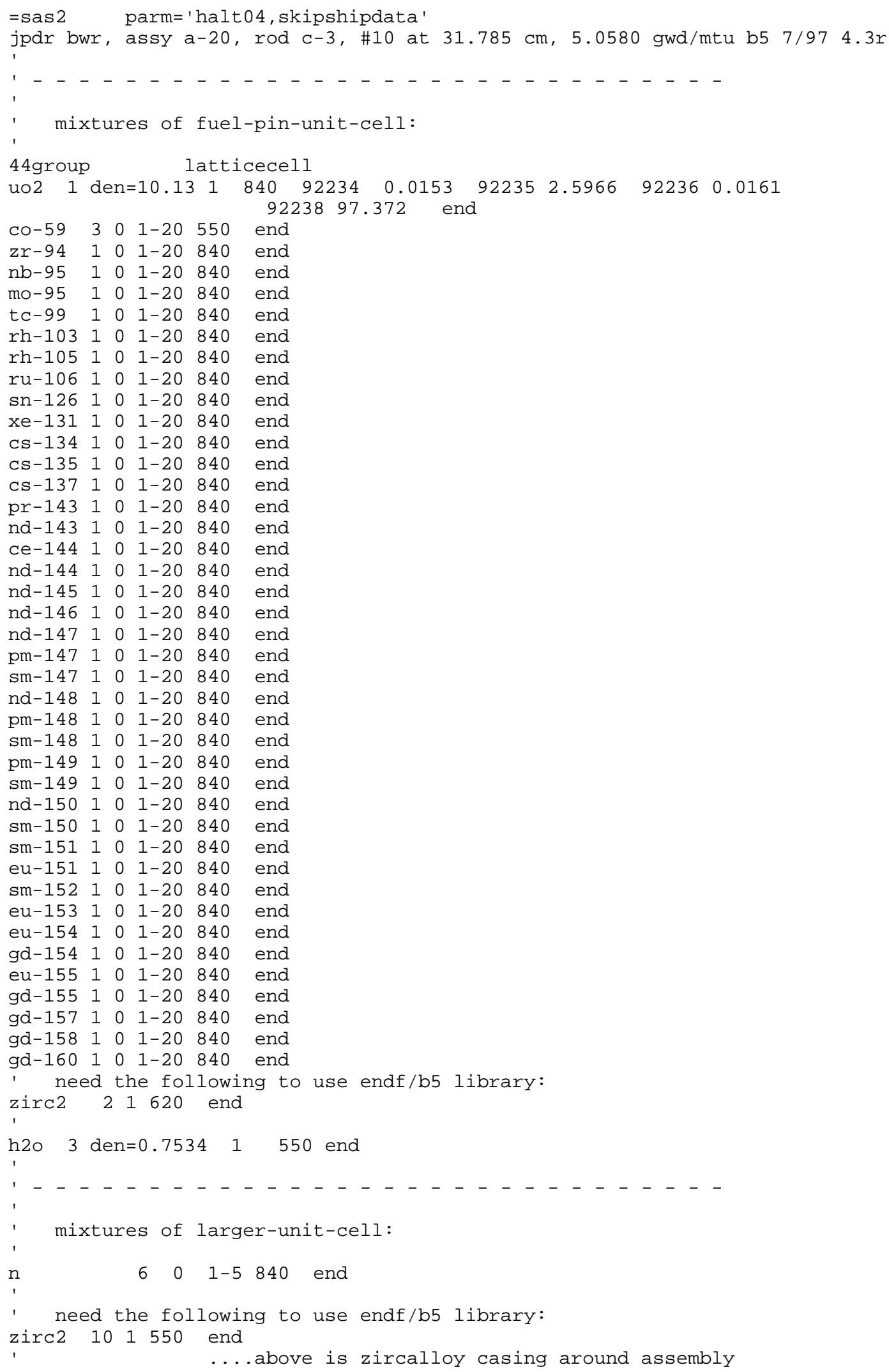




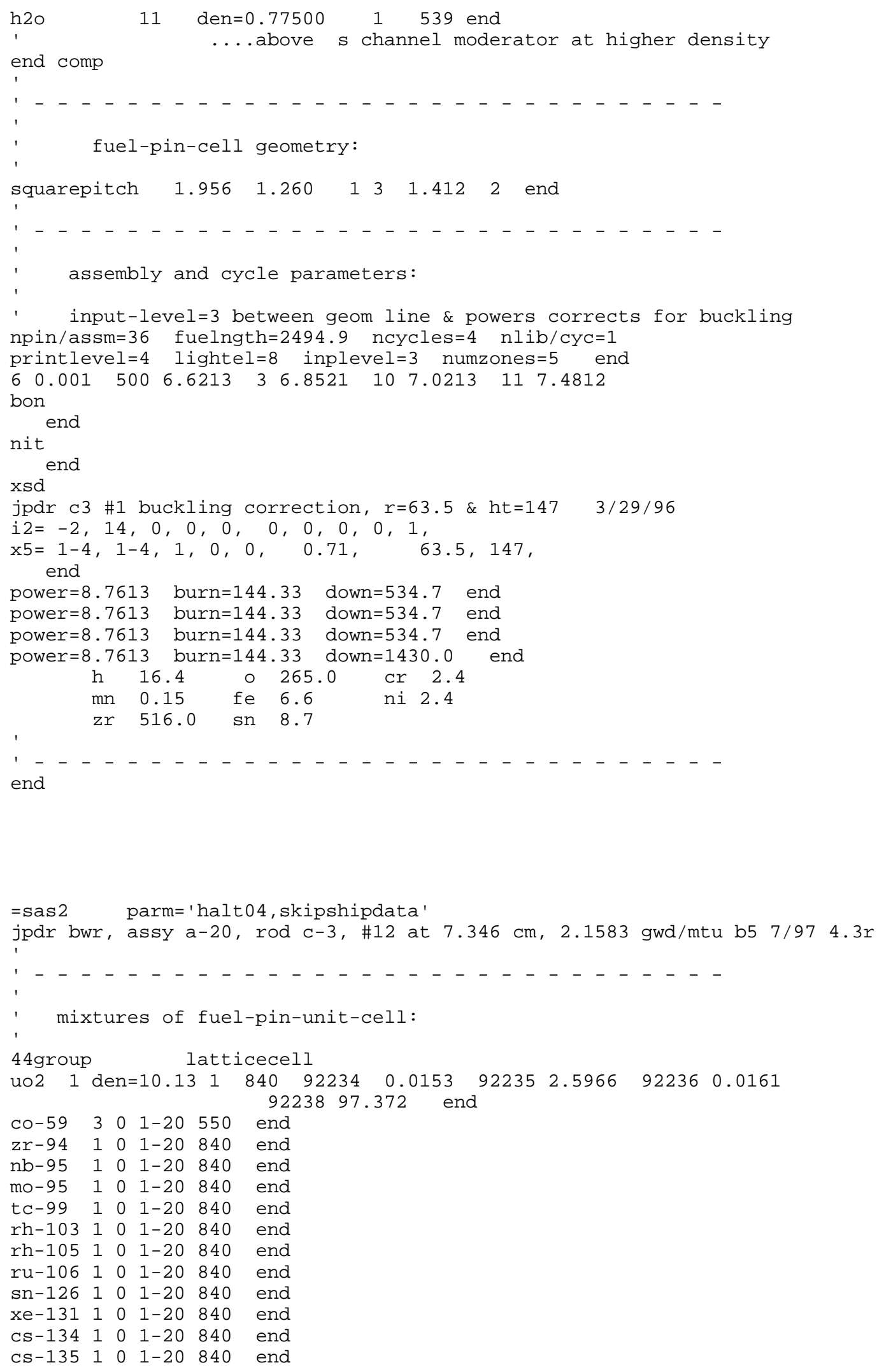




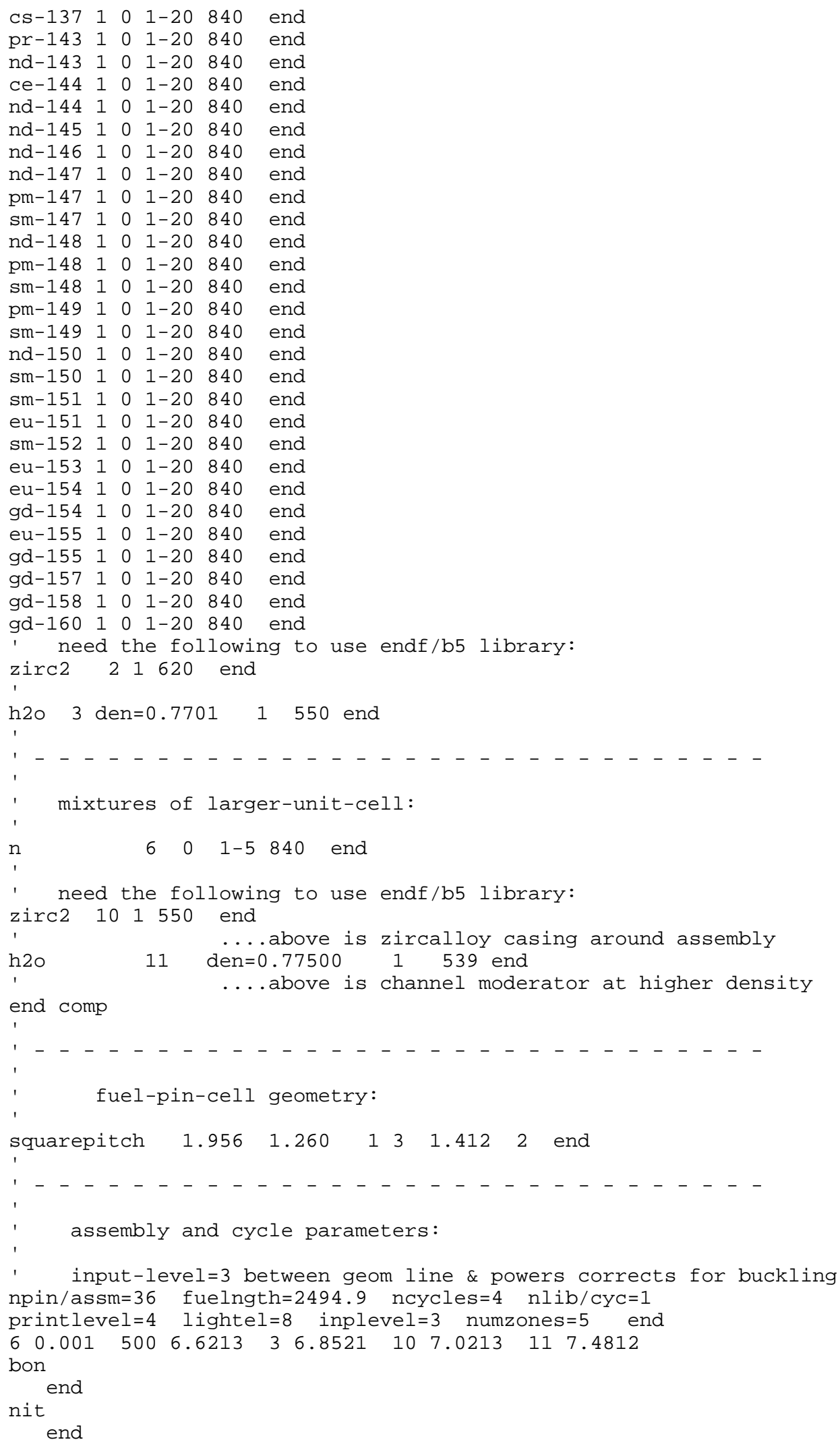




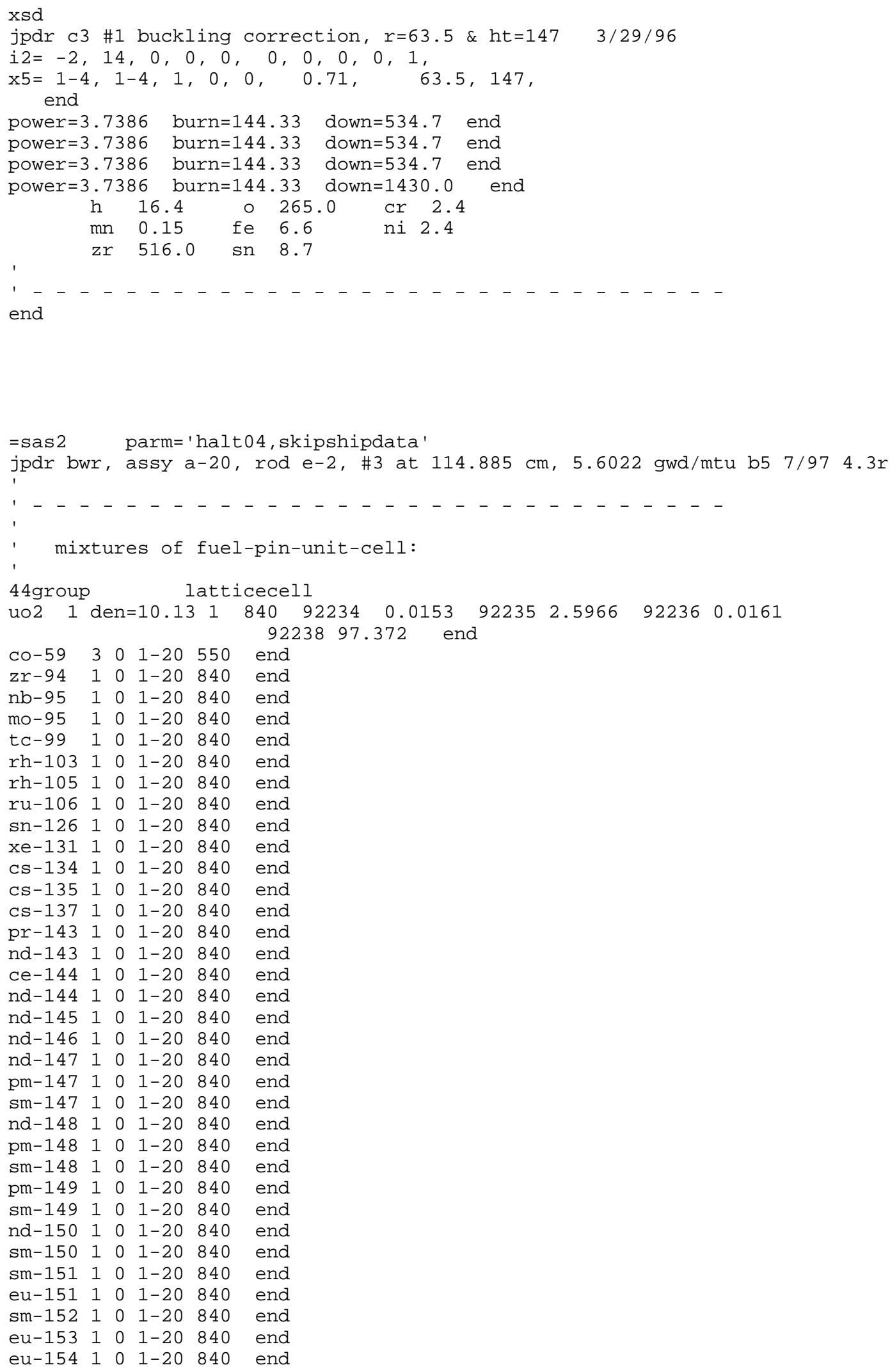




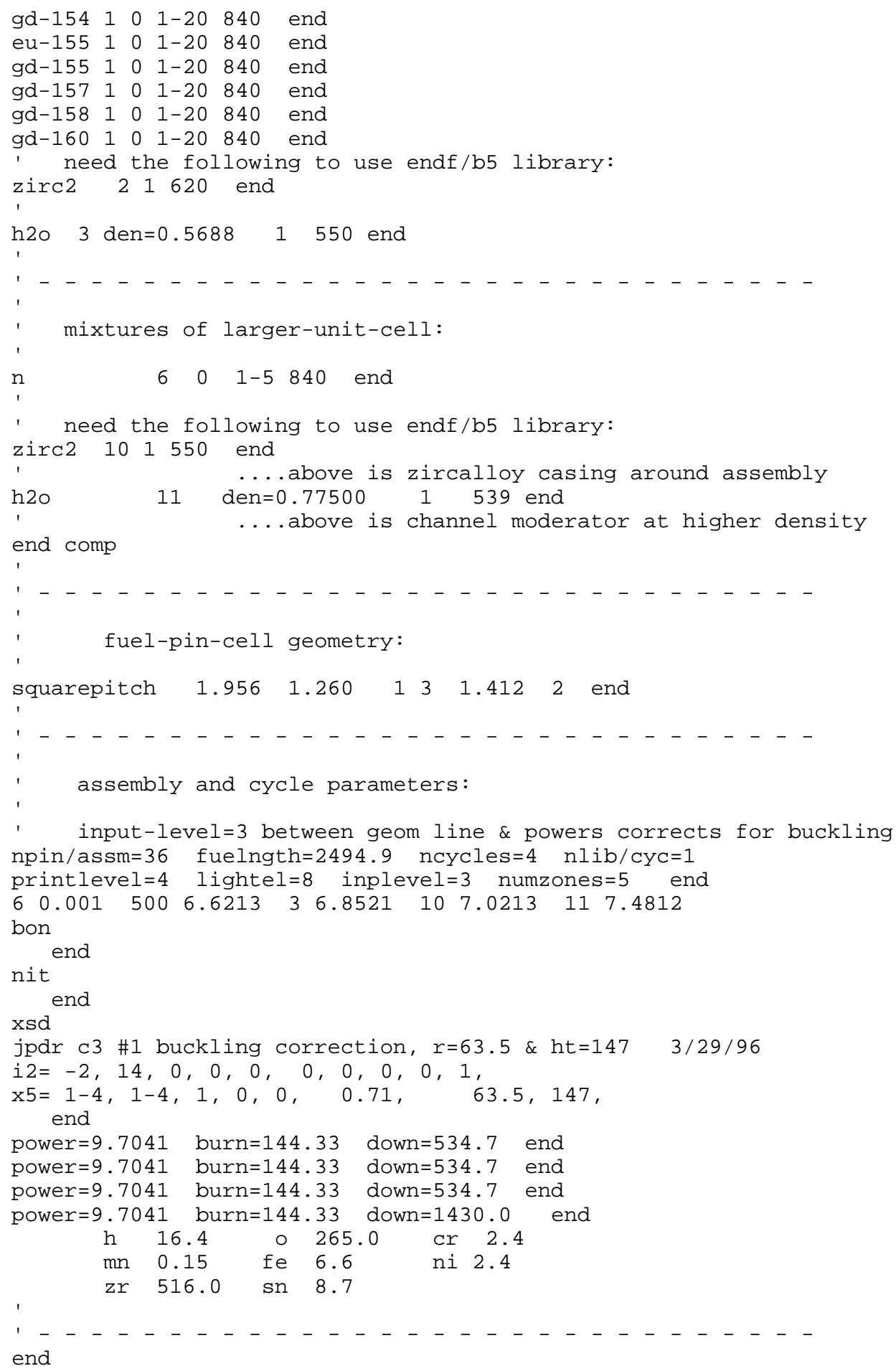




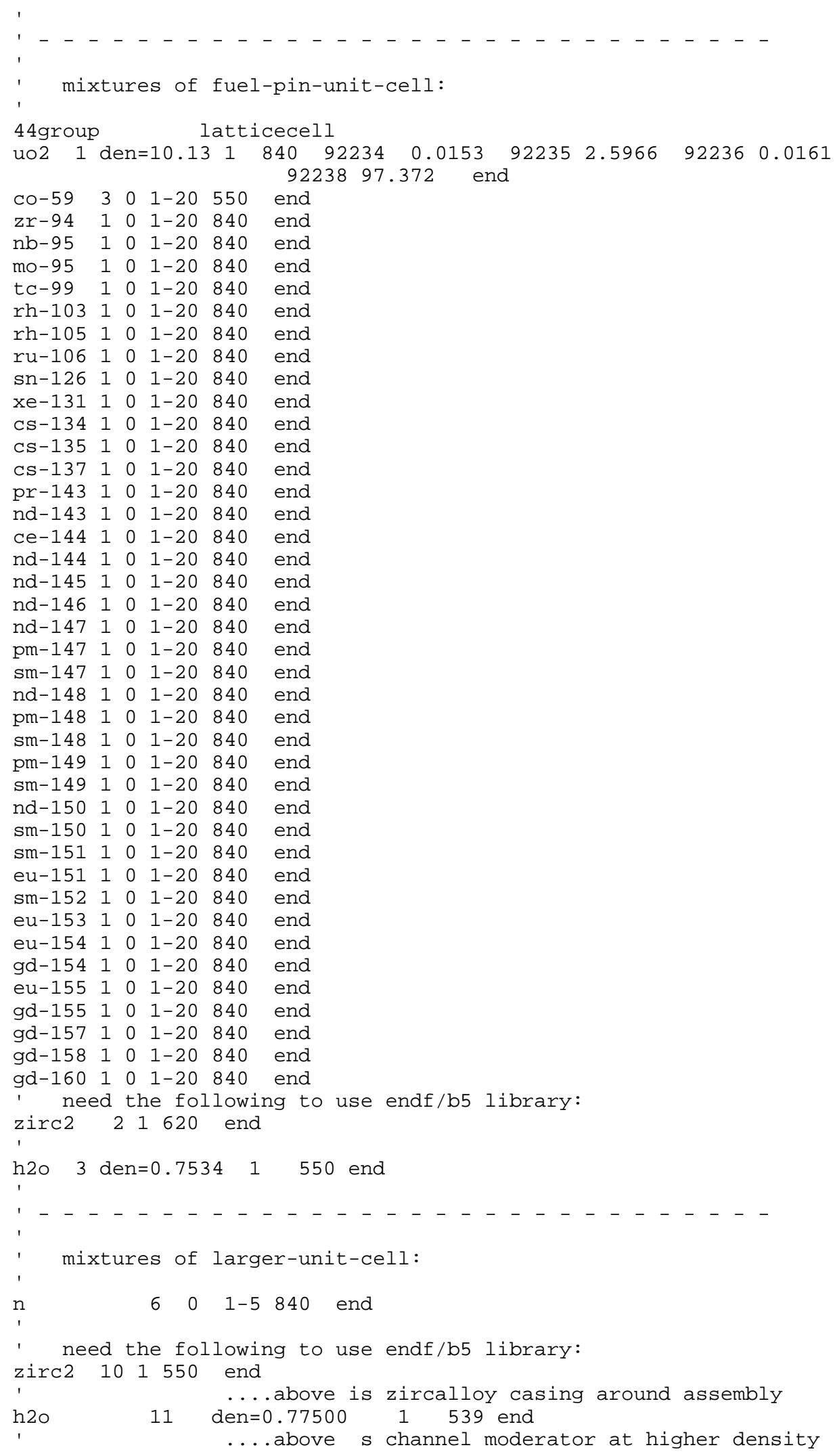




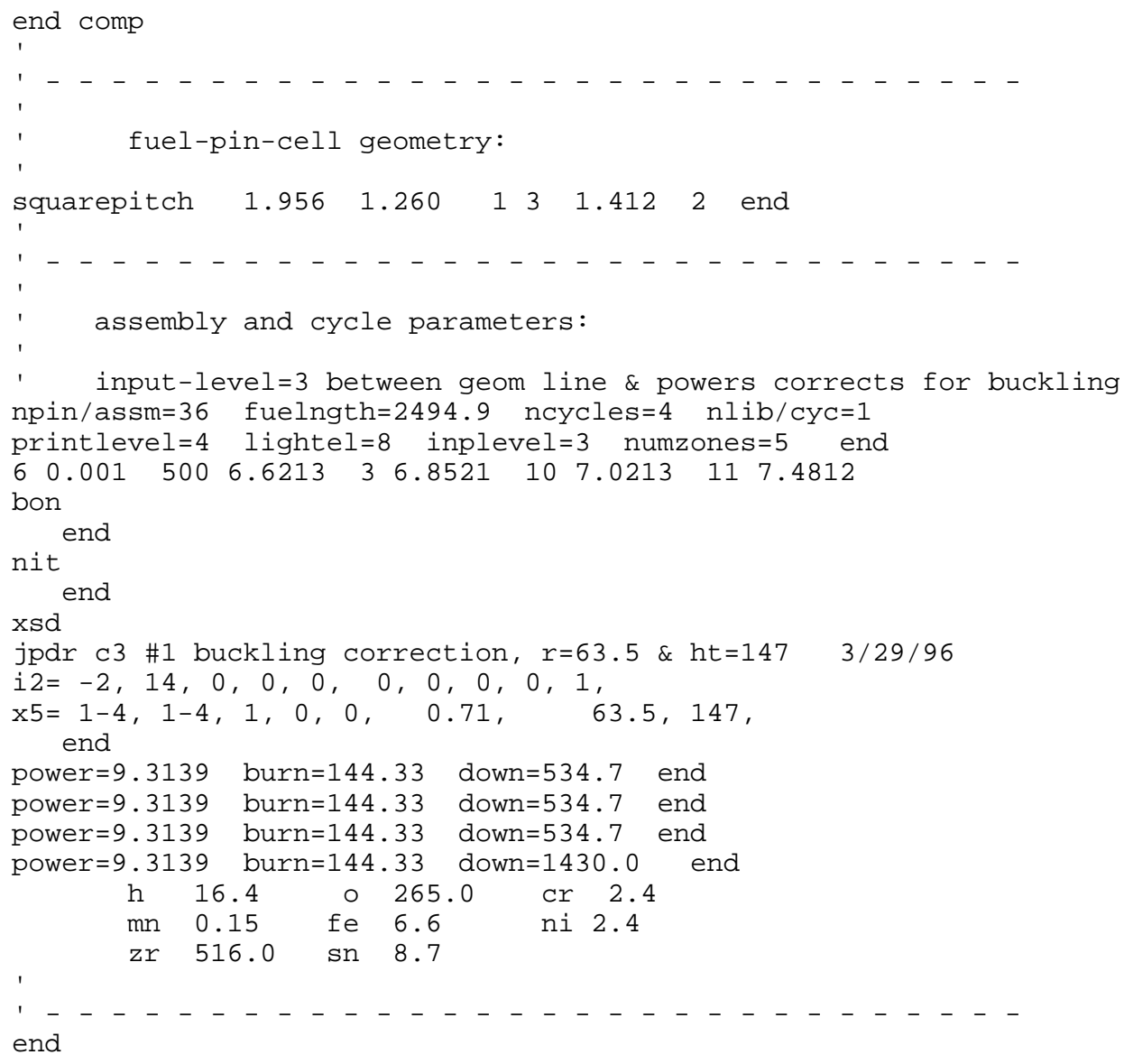




\section{APPENDIX E}

\section{MEASURED AND COMPUTED ISOTOPIC CONCENTRATIONS FOR COOPER BWR FUEL SAMPLES}

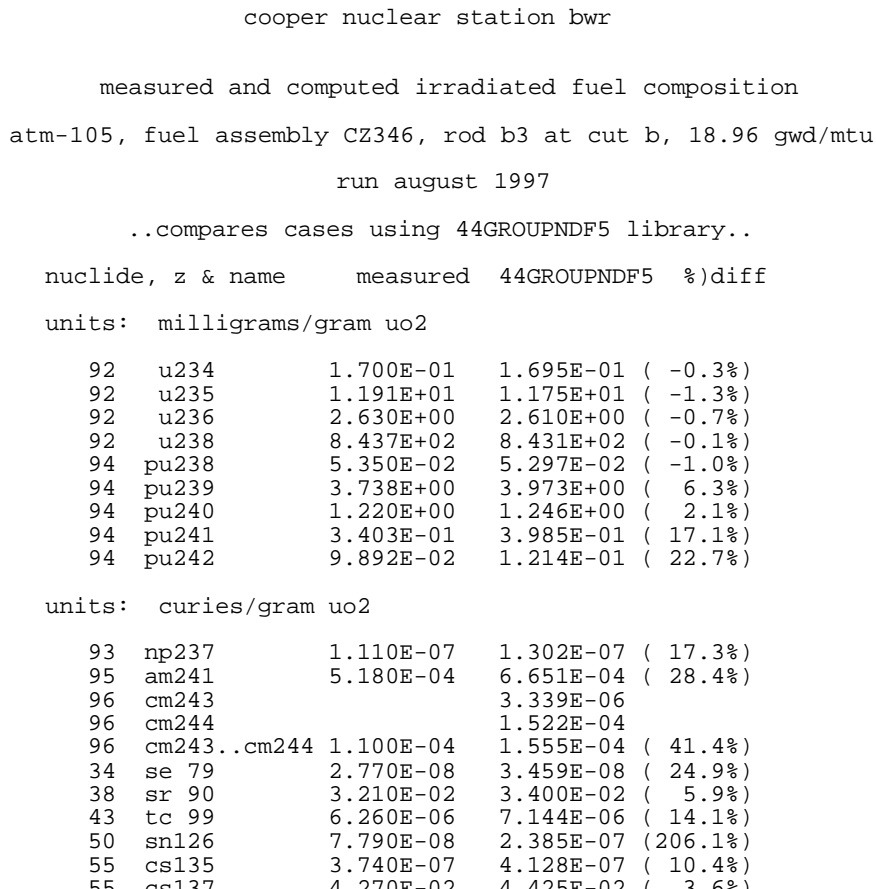


cooper nuclear station bwr

measured and computed irradiated fuel composition

atm-105, fuel assembly CZ346, rod b3 at cut $t, 33.94 \mathrm{gwd} / \mathrm{mtu}$

run august 1997

. compares cases using 44GROUPNDF5 library..

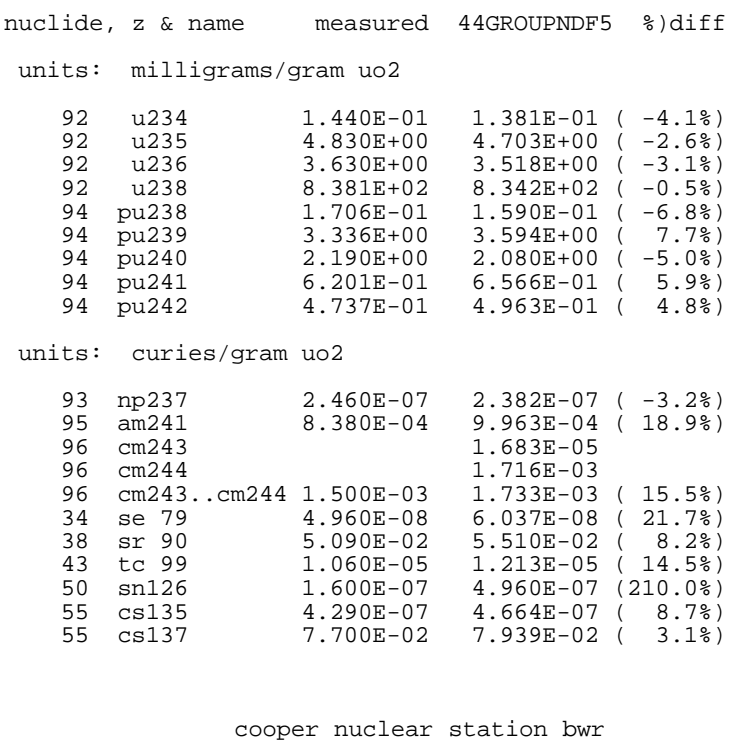


cooper nuclear station bwr

measured and computed irradiated fuel composition

atm-105, fuel assembly CZ346, rod c3 at cut j, $29.23 \mathrm{gwd} / \mathrm{mtu}$

run august 1997

. compares cases using 44GROUPNDF5 library..

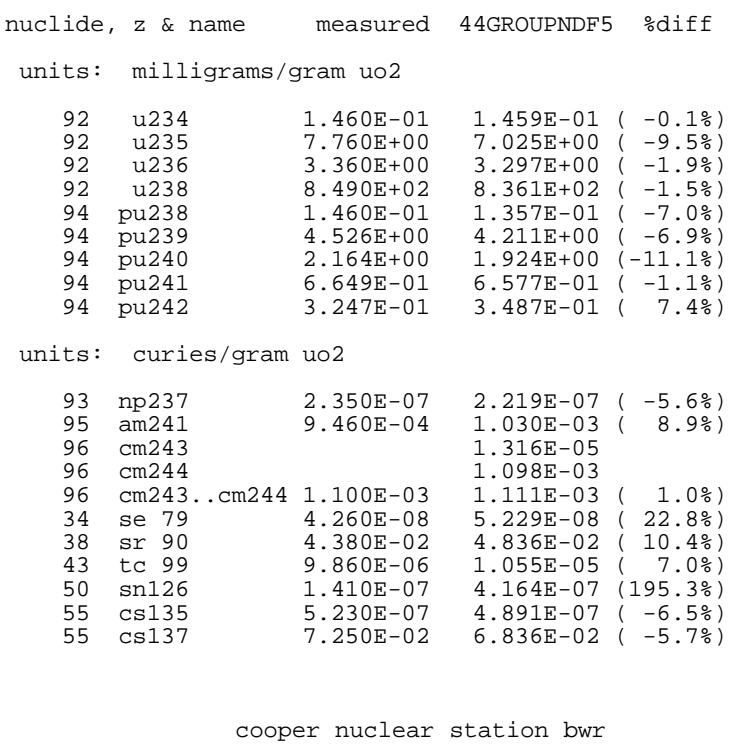




\section{APPENDIX F}

\section{MEASURED AND COMPUTED ISOTOPIC CONCENTRATIONS FOR GUNDREMMINGEN BWR FUEL SAMPLES}

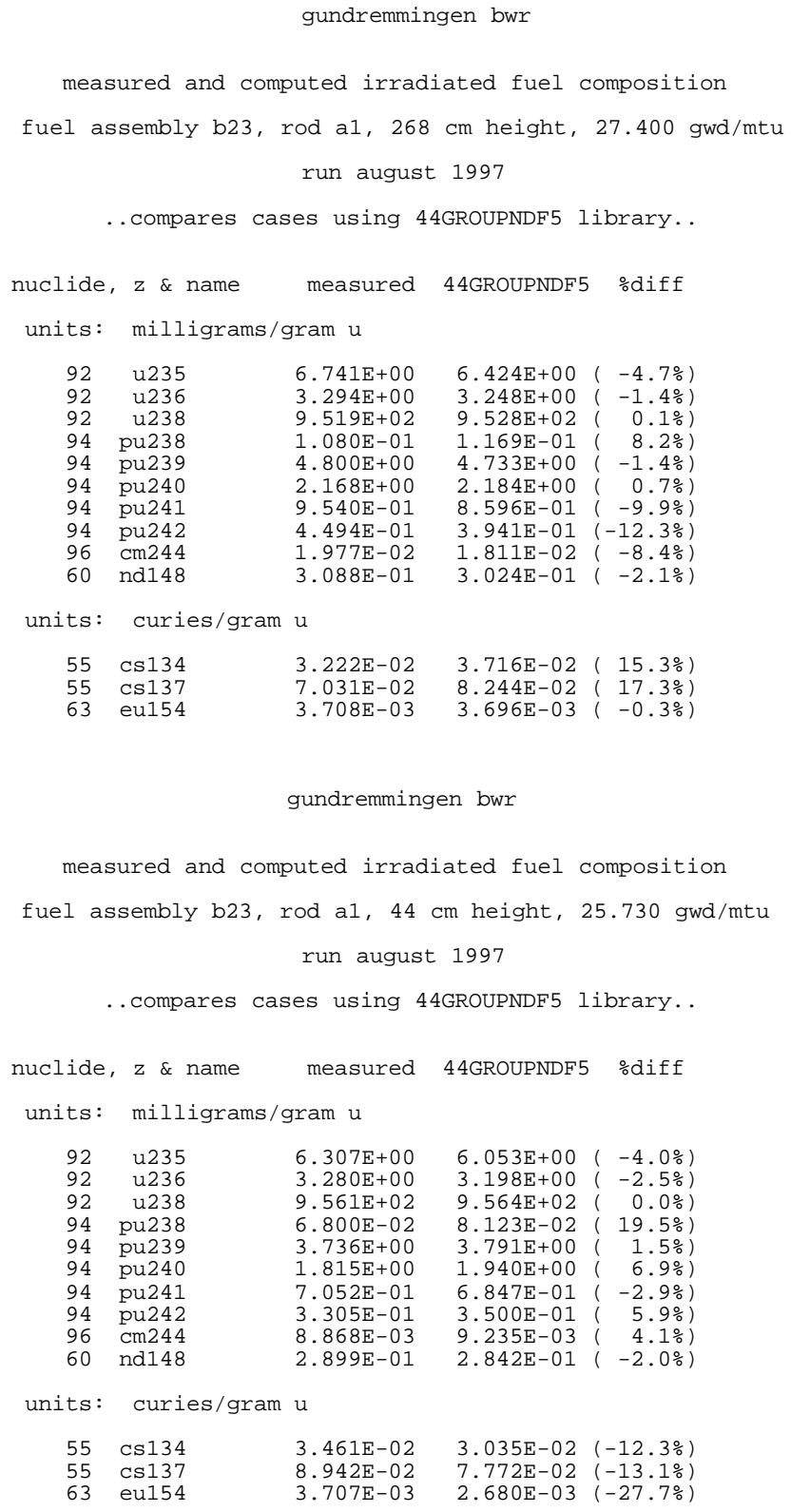


gundremmingen bwr

measured and computed irradiated fuel composition

fuel assembly b23, rod b3, $268 \mathrm{~cm}$ height, $21.240 \mathrm{gwd} / \mathrm{mtu}$

run august 1997

. compares cases using 44GROUPNDF5 library..

$\begin{array}{rlrrr}\text { nuclide, } & z \& \text { name } & \text { measured } & \text { 44GROUPNDF5 } & \% \text { diff } \\ \text { units: } & \text { milligrams/gram u } \\ 92 & \text { u235 } & 9.823 \mathrm{E}+00 & 9.072 \mathrm{E}+00 & (-7.6 \%) \\ 92 & \text { u236 } & 2.952 \mathrm{E}+00 & 2.882 \mathrm{E}+00 & (-2.4 \%) \\ 92 & \mathrm{u} 238 & 9.559 \mathrm{E}+02 & 9.580 \mathrm{E}+02 & (0.2 \%) \\ 94 & \text { pu238 } & 8.300 \mathrm{E}-02 & 6.785 \mathrm{E}-02 & (-18.3 \%) \\ 94 & \text { pu239 } & 5.372 \mathrm{E}+00 & 4.536 \mathrm{E}+00 & (-15.6 \%) \\ 94 & \text { pu240 } & 1.855 \mathrm{E}+00 & 1.709 \mathrm{E}+00 & (-7.9 \%) \\ 94 & \text { pu241 } & 7.855 \mathrm{E}-01 & 6.597 \mathrm{E}-01 & (-16.0 \%) \\ 94 & \text { pu242 } & 2.232 \mathrm{E}-01 & 2.183 \mathrm{E}-01 & (-2.2 \%) \\ 96 & \text { cm244 } & 8.622 \mathrm{E}-03 & 5.760 \mathrm{E}-03 & (-33.2 \%) \\ 60 & \text { nd148 } & 2.394 \mathrm{E}-01 & 2.350 \mathrm{E}-01 & (-1.8 \%) \\ & & & \\ \text { units: } & \text { curies/gram u } & & \\ 55 & \text { cs134 } & 2.645 \mathrm{E}-02 & 2.361 \mathrm{E}-02 & (-10.7 \%) \\ 55 & \text { cs137 } & 6.485 \mathrm{E}-02 & 6.408 \mathrm{E}-02 & (-1.2 \%) \\ 63 & \text { eu154 } & 3.246 \mathrm{E}-03 & 2.367 \mathrm{E}-03 & (-27.1 \%)\end{array}$

gundremmingen bwr

measured and computed irradiated fuel composition

fuel assembly b23, rod e3, $268 \mathrm{~cm}$ height, $23.510 \mathrm{gwd} / \mathrm{mtu}$

run august 1997

. compares cases using 44GROUPNDF5 library..

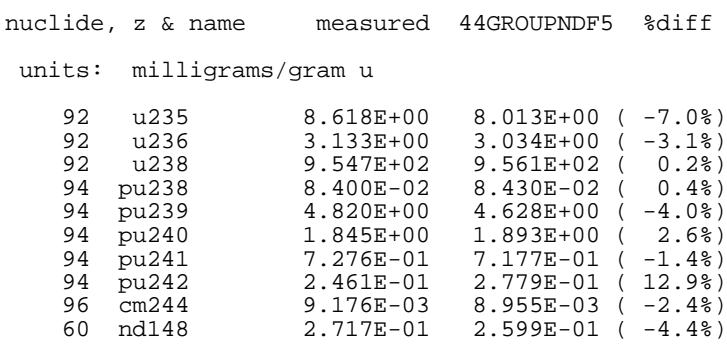

units: curies/gram u

$\begin{array}{lllll}55 & \operatorname{cs} 134 & 2.481 \mathrm{E}-02 & 2.319 \mathrm{E}-02 & (-6.5 \%) \\ 55 & \operatorname{cs} 137 & 6.640 \mathrm{E}-02 & 6.989 \mathrm{E}-02 & (5.3 \%) \\ 63 & \text { eu154 } & 3.035 \mathrm{E}-03 & 2.708 \mathrm{E}-03 & (-10.8 \%)\end{array}$


gundremmingen bwr

measured and computed irradiated fuel composition

fuel assembly c16, rod a1, $268 \mathrm{~cm}$ height, $20.300 \mathrm{gwd} / \mathrm{mtu}$

run august 1997

. compares cases using 44GROUPNDF5 library..

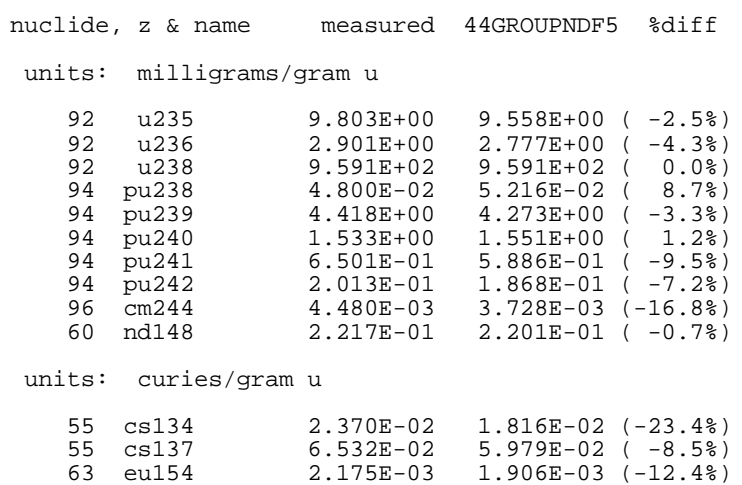

gundremmingen bwr

measured and computed irradiated fuel composition

fuel assembly c16, rod a1, $44 \mathrm{~cm}$ height, $19.850 \mathrm{gwd} / \mathrm{mtu}$

run august 1997

..compares cases using 44GROUPNDF5 library..

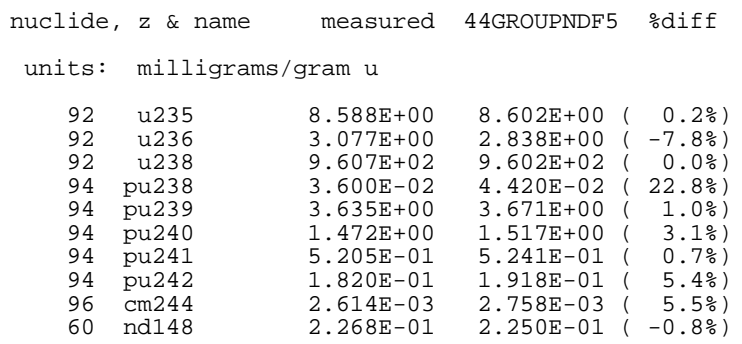

units: curies/gram u

$\begin{array}{lllll}55 & \operatorname{cs} 134 & 1.884 \mathrm{E}-02 & 1.739 \mathrm{E}-02 & (-7.7 \%) \\ 55 & \operatorname{cs} 137 & 6.196 \mathrm{E}-02 & 6.132 \mathrm{E}-02 & (-1.0 \%) \\ 63 & \text { eu154 } & 1.777 \mathrm{E}-03 & 1.668 \mathrm{E}-03 & (-6.1 \%)\end{array}$


gundremmingen bwr

measured and computed irradiated fuel composition

fuel assembly c16, rod b3, $268 \mathrm{~cm}$ height, $14.390 \mathrm{gwd} / \mathrm{mtu}$

run august 1997

. compares cases using 44GROUPNDF5 library..

$\begin{array}{rlrrr}\text { nuclide, } & \text { z \& name } & \text { measured } & \text { 44GROUPNDF5 } & \% \text { diff } \\ \text { units: } & \text { milligrams/gram u } & & \\ 92 & \text { u235 } & 1.311 \mathrm{E}+01 & 1.277 \mathrm{E}+01 & (-2.6 \%) \\ 92 & \mathrm{u} 236 & 2.452 \mathrm{E}+00 & 2.280 \mathrm{E}+00 & (-7.0 \%) \\ 92 & \mathrm{u} 238 & 9.621 \mathrm{E}+02 & 9.634 \mathrm{E}+02 & (0.1 \%) \\ 94 & \text { pu238 } & 3.300 \mathrm{E}-02 & 2.508 \mathrm{E}-02 & (-24.0 \%) \\ 94 & \text { pu239 } & 4.695 \mathrm{E}+00 & 3.885 \mathrm{E}+00 & (-17.3 \%) \\ 94 & \text { pu240 } & 1.170 \mathrm{E}+00 & 1.078 \mathrm{E}+00 & (-7.8 \%) \\ 94 & \text { pu241 } & 4.807 \mathrm{E}-01 & 3.862 \mathrm{E}-01 & (-19.7 \%) \\ 94 & \text { pu242 } & 8.897 \mathrm{E}-02 & 8.060 \mathrm{E}-02 & (-9.4 \%) \\ 96 & \text { cm244 } & 1.569 \mathrm{E}-03 & 7.937 \mathrm{E}-04 & (-49.4 \%) \\ 60 & \text { nd148 } & 1.632 \mathrm{E}-01 & 1.599 \mathrm{E}-01 & (-2.1 \%) \\ & & & \\ \text { units: } & \text { curies/gram u } & & \\ 55 & \text { cs134 } & 1.438 \mathrm{E}-02 & 1.141 \mathrm{E}-02 & (-20.6 \%) \\ 55 & \text { cS137 } & 4.621 \mathrm{E}-02 & 4.382 \mathrm{E}-02 & (-5.2 \%) \\ 63 & \text { eu154 } & 1.568 \mathrm{E}-03 & 1.062 \mathrm{E}-03 & (-32.3 \%)\end{array}$

gundremmingen bwr

measured and computed irradiated fuel composition

fuel assembly c16, rod e5, $268 \mathrm{~cm}$ height, $17.490 \mathrm{gwd} / \mathrm{mtu}$

run august 1997

. compares cases using 44GROUPNDF5 library..

nuclide, $z$ \& name measured 44GROUPNDF5 \%diff

units: milligrams/gram u

$\begin{array}{lrrrrr}92 & \text { u235 } & 1.044 \mathrm{E}+01 & 1.086 \mathrm{E}+01 & (4.0 \%) \\ 92 & \text { u236 } & 2.740 \mathrm{E}+00 & 2.580 \mathrm{E}+00 & (-5.9 \%) \\ 92 & \mathrm{u} 238 & 9.612 \mathrm{E}+02 & 9.610 \mathrm{E}+02 & (0.0 \%) \\ 94 & \text { pu238 } & 4.100 \mathrm{E}-02 & 3.934 \mathrm{E}-02 & (-4.1 \%) \\ 94 & \text { pu239 } & 4.157 \mathrm{E}+00 & 4.138 \mathrm{E}+00 & (-0.5 \%) \\ 94 & \text { pu240 } & 1.442 \mathrm{E}+00 & 1.352 \mathrm{E}+00 & (-6.2 \%) \\ 94 & \text { pu241 } & 5.328 \mathrm{E}-01 & 5.153 \mathrm{E}-01 & (-3.3 \%) \\ 94 & \text { pu242 } & 1.500 \mathrm{E}-01 & 1.353 \mathrm{E}-01 & (-9.8 \%) \\ 96 & \mathrm{~cm} 244 & 2.794 \mathrm{E}-03 & 2.081 \mathrm{E}-03 & (-25.5 \%) \\ 60 & \text { nd148 } & 1.989 \mathrm{E}-01 & 1.940 \mathrm{E}-01 & (-2.4 \%)\end{array}$

units: curies/gram u

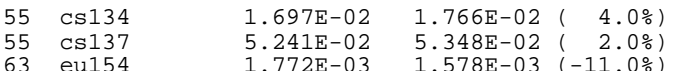




\title{
APPENDIX G
}

\section{MEASURED AND COMPUTED ISOTOPIC CONCENTRATIONS FOR JPDR BWR FUEL SAMPLES}

\author{
japan power demonstration reactor bwr \\ measured and computed irradiated fuel composition \\ fuel assembly a-14, mid-rod, node 2, 3.303 gwd/mtu \\ run august 1997 \\ ..compares cases using 44GROUPNDF5 library..

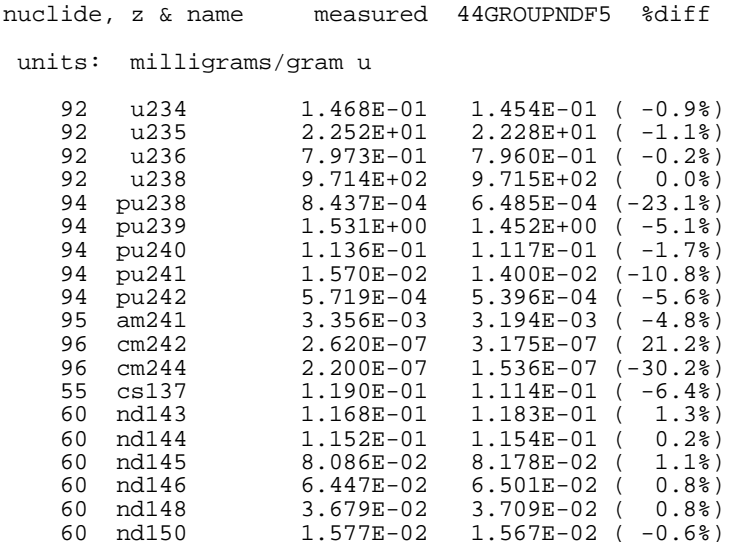 \\ japan power demonstration reactor bwr \\ measured and computed irradiated fuel composition \\ fuel assembly a-14, mid-rod, node 9, 4.035 gwd/mtu \\ run august 1997 \\ . compares cases using 44GROUPNDF5 library..

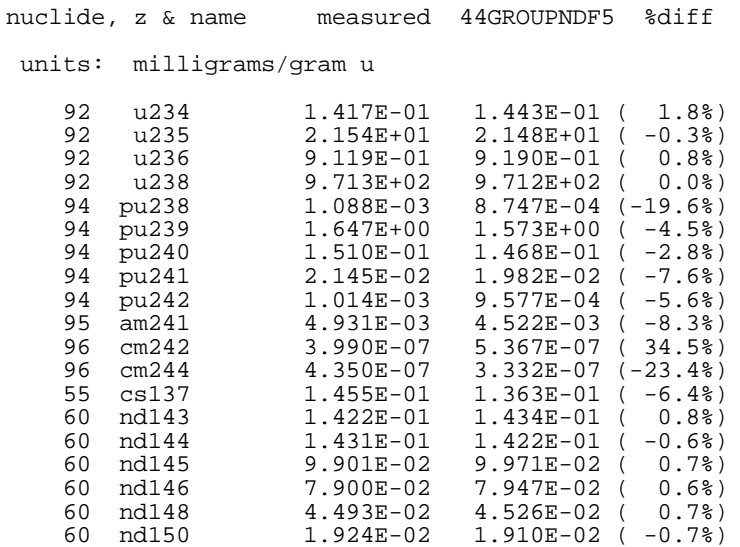


japan power demonstration reactor bwr

measured and computed irradiated fuel composition

fuel assembly a-18, mid-rod, node 2, 2.712 gwd/mtu

run august 1997

. compares cases using 44GROUPNDF5 library..

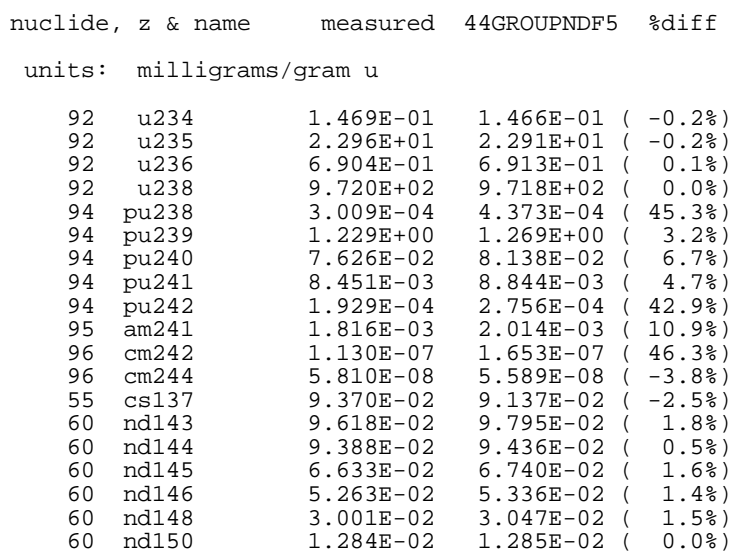

japan power demonstration reactor bwr

measured and computed irradiated fuel composition

fuel assembly a-18, mid-rod, node 6, $4.251 \mathrm{gwd} / \mathrm{mtu}$

run august 1997

. compares cases using 44GROUPNDF5 library..

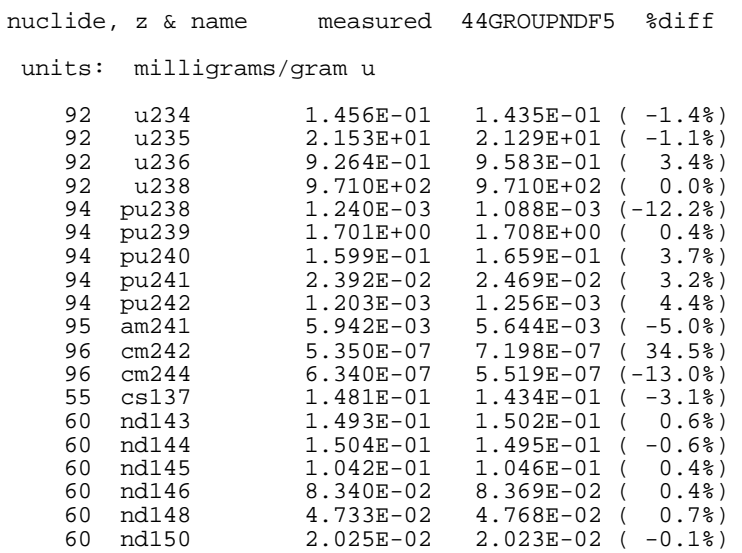


japan power demonstration reactor bwr

measured and computed irradiated fuel composition

fuel assembly a-20, rod a1, node 3, 7.0098 gwd/mtu

run august 1997

. compares cases using 44GROUPNDF5 library..

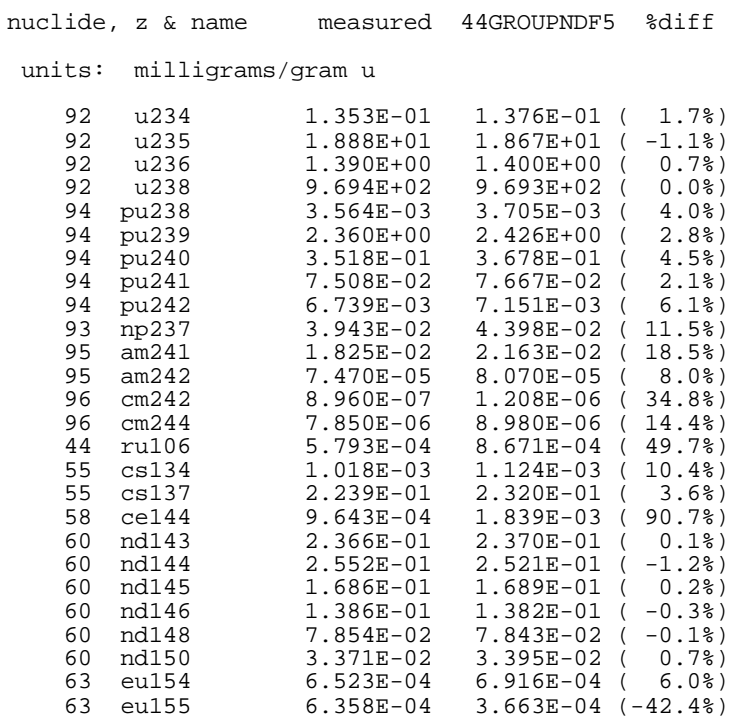

japan power demonstration reactor bwr

measured and computed irradiated fuel composition

fuel assembly a-20, rod a3, node 10, $6.1464 \mathrm{gwd} / \mathrm{mtu}$ run august 1997

..compares cases using 44GROUPNDF5 library..

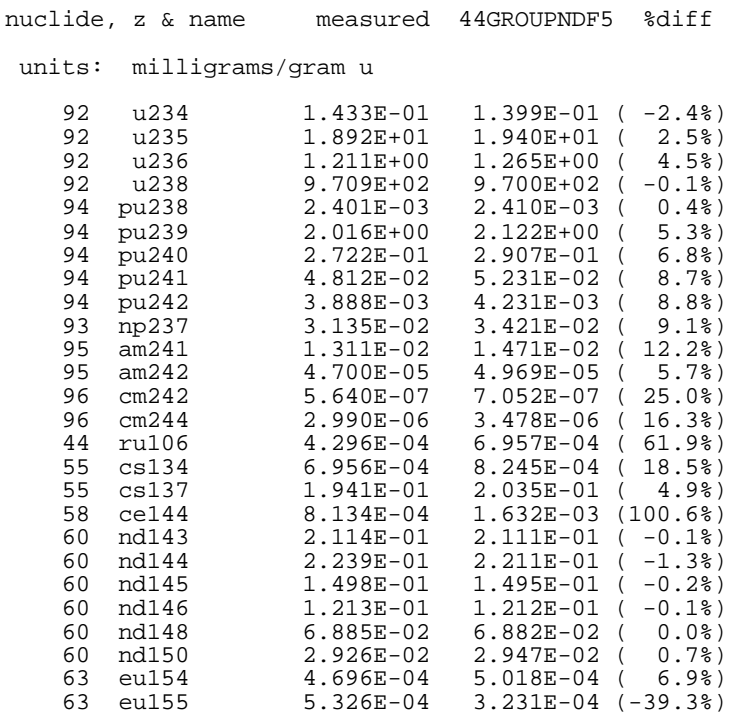


japan power demonstration reactor bwr

measured and computed irradiated fuel composition

fuel assembly a-20, rod a6, node 3, $6.9535 \mathrm{gwd} / \mathrm{mtu}$

run august 1997

. compares cases using 44GROUPNDF5 library..

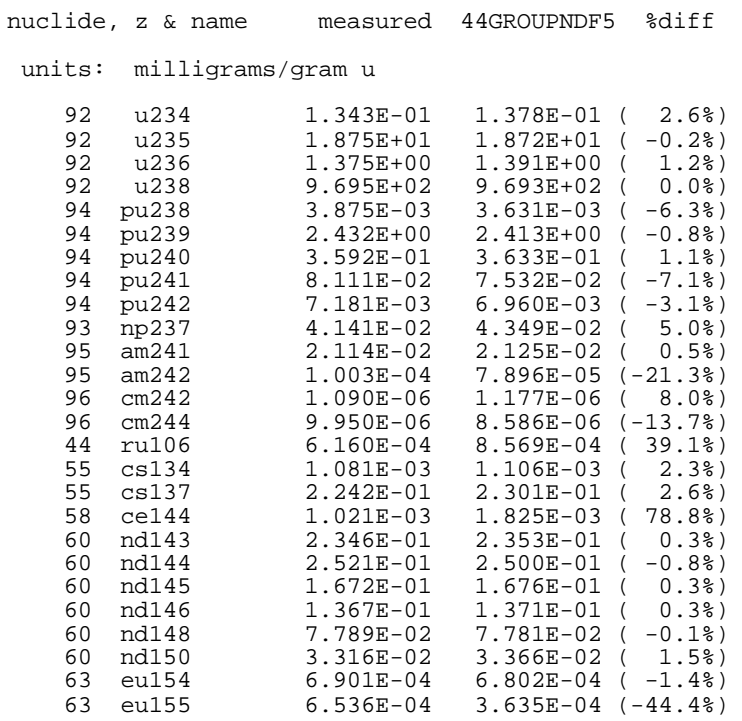

japan power demonstration reactor bwr

measured and computed irradiated fuel composition

fuel assembly a-20, rod a6, node 9, $6.5125 \mathrm{gwd} / \mathrm{mtu}$ run august 1997

..compares cases using 44GROUPNDF5 library..

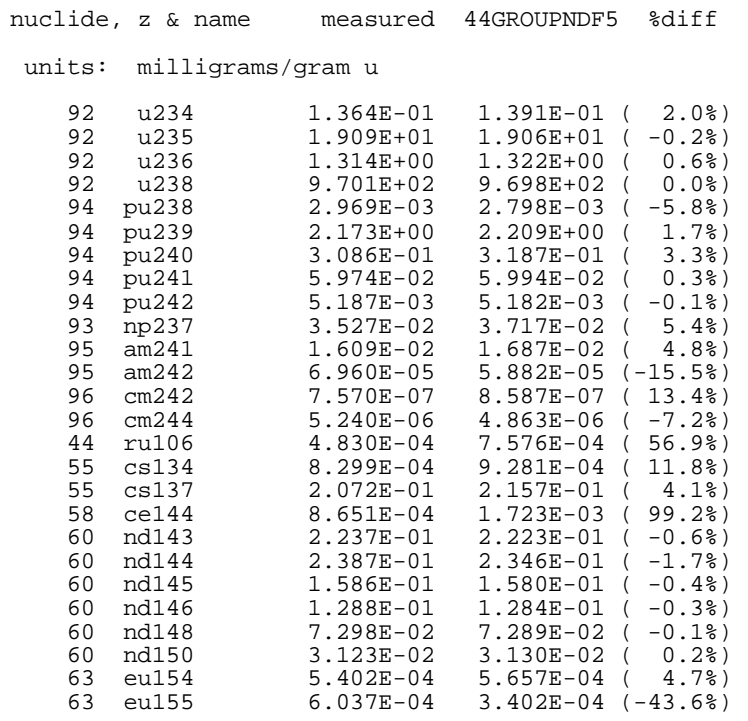


japan power demonstration reactor bwr

measured and computed irradiated fuel composition

fuel assembly a-20, rod c3, node 1, $2.6463 \mathrm{gwd} / \mathrm{mtu}$

run august 1997

. compares cases using 44GROUPNDF5 library..

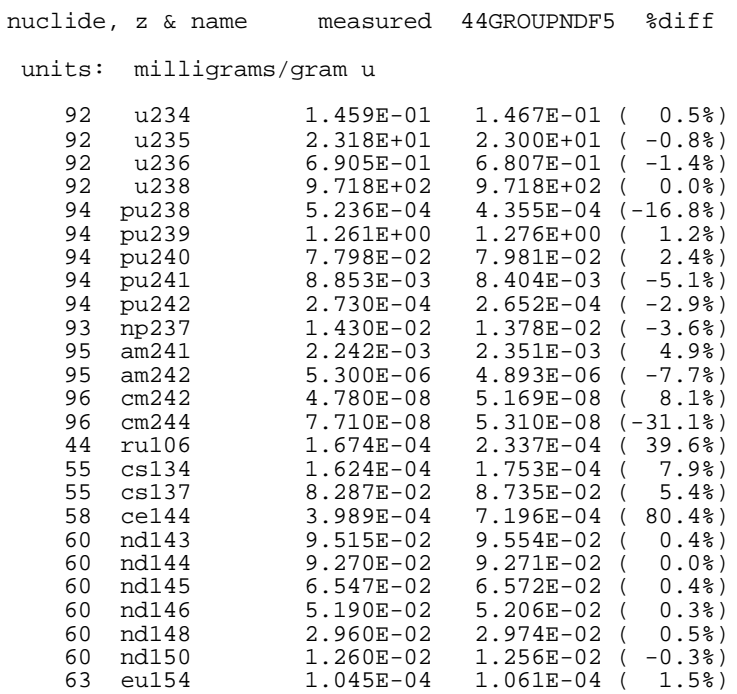

japan power demonstration reactor bwr

measured and computed irradiated fuel composition

fuel assembly a-20, rod c3, node 3, $5.0861 \mathrm{gwd} / \mathrm{mtu}$

run august 1997

. compares cases using 44GROUPNDF5 library..

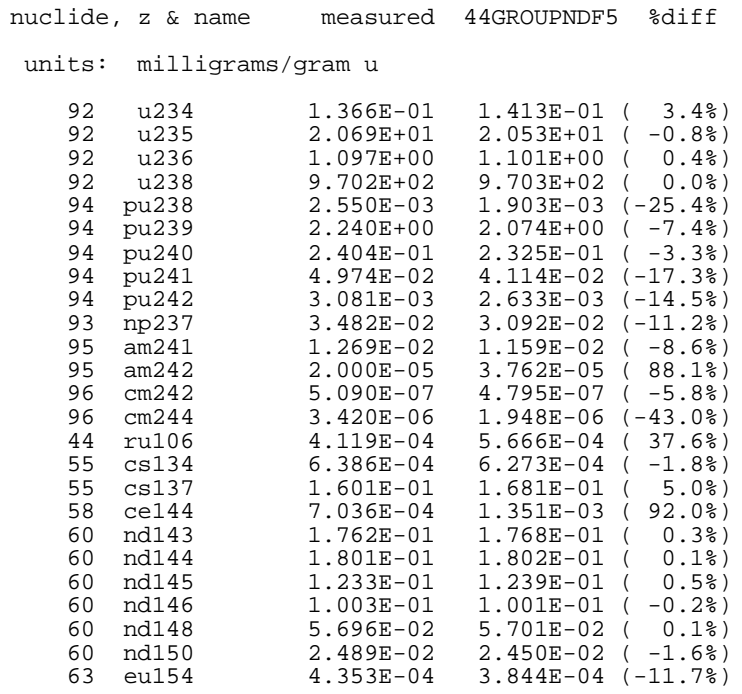


japan power demonstration reactor bwr

measured and computed irradiated fuel composition

fuel assembly a-20, rod c3, node 5, 6.0808 gwd/mtu

run august 1997

. compares cases using 44GROUPNDF5 library..

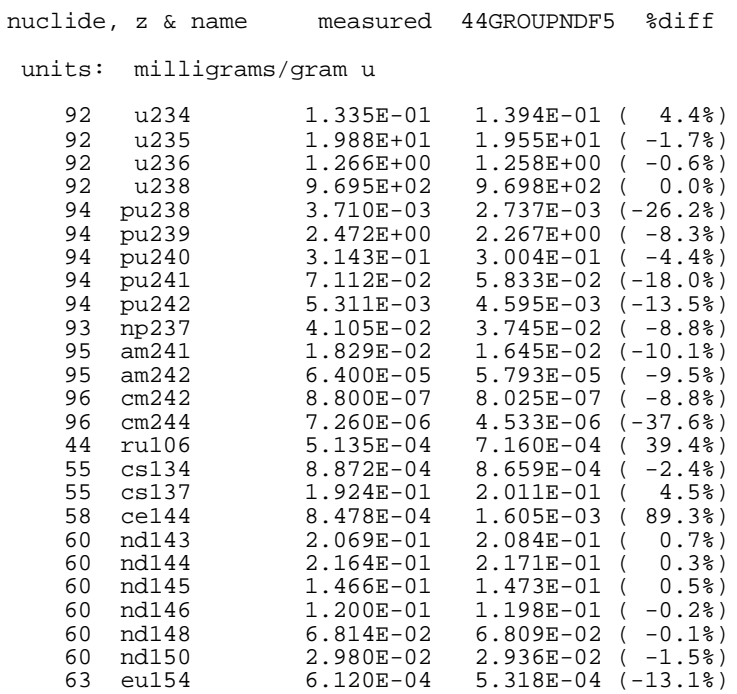

japan power demonstration reactor bwr

measured and computed irradiated fuel composition

fuel assembly a-20, rod c3, node 8, $6.0433 \mathrm{gwd} / \mathrm{mtu}$

run august 1997

. compares cases using 44GROUPNDF5 library..

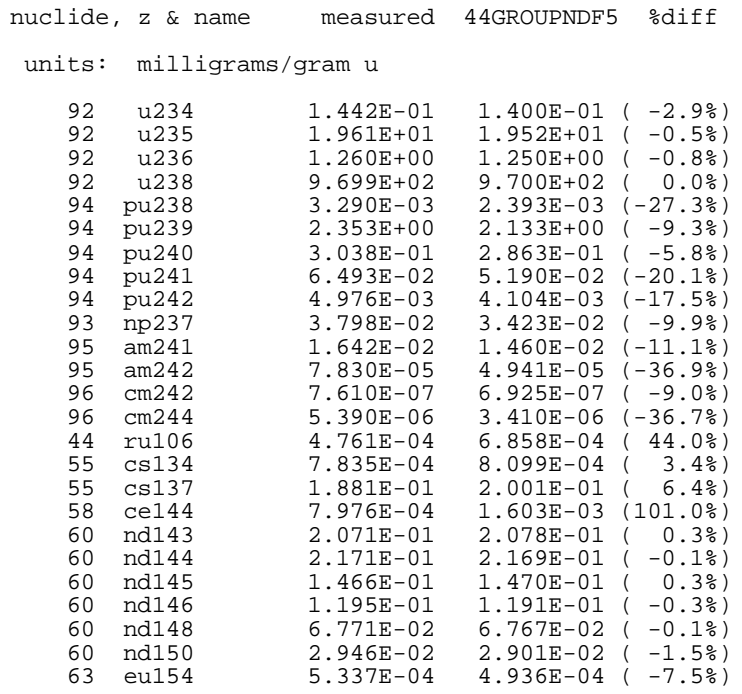


japan power demonstration reactor bwr

measured and computed irradiated fuel composition

fuel assembly a-20, rod c3, node 10, $5.058 \mathrm{gwd} / \mathrm{mtu}$

run august 1997

. compares cases using 44GROUPNDF5 library..

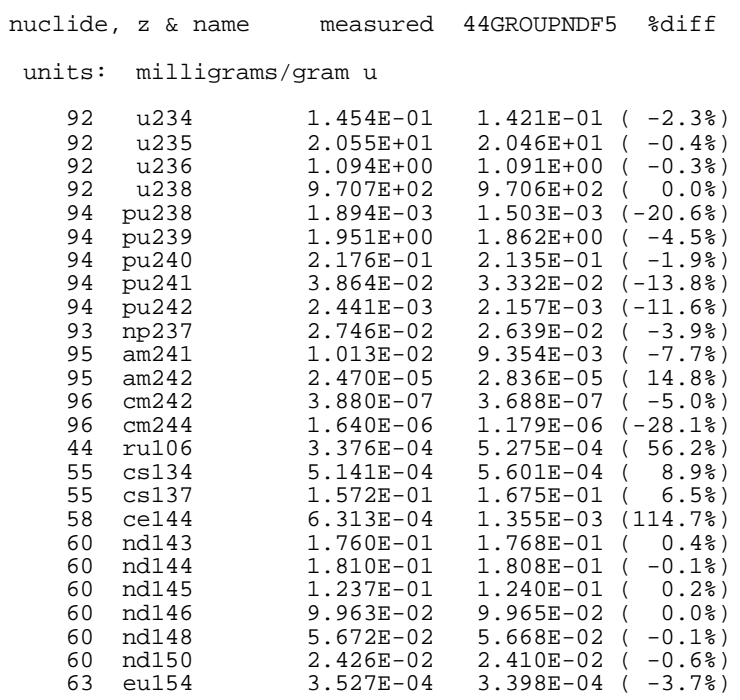

japan power demonstration reactor bwr

measured and computed irradiated fuel composition

fuel assembly a-20, rod c3, node 12, $2.158 \mathrm{gwd} / \mathrm{mtu}$

run august 1997

..compares cases using 44GROUPNDF5 library..

nuclide, $z$ \& name measured 44GROUPNDF5 \%diff

units: milligrams/gram u

\begin{tabular}{|c|c|c|c|}
\hline u234 & $1.510 \mathrm{E}-01$ & 1. $483 \mathrm{E}-01$ & $(-1.8 \%)$ \\
\hline u235 & $2.354 \mathrm{E}+01$ & $2.347 \mathrm{E}+01$ & $-0.3 \%)$ \\
\hline u236 & $5.843 \mathrm{E}-01$ & $5.833 \mathrm{E}-01$ & $-0.2 \%)$ \\
\hline u238 & $9.724 \mathrm{E}+02$ & $9.723 \mathrm{E}+02$ & $0.0 \%)$ \\
\hline pu238 & $2.511 \mathrm{E}-04$ & $2.017 \mathrm{E}-04$ & $(-19.7 \%)$ \\
\hline pu239 & $9.554 \mathrm{E}-01$ & $9.310 \mathrm{E}-01$ & $(-2.6 \%)$ \\
\hline pu2 240 & $4.913 \mathrm{E}-02$ & $4.862 \mathrm{E}-02$ & $-1.0 \%)$ \\
\hline pu241 & $3.955 E-03$ & $3.535 \mathrm{E}-03$ & $(-10 \cdot 6 \%)$ \\
\hline pu2 242 & $1.021 \mathrm{E}-04$ & $9.129 \mathrm{E}-05$ & $(-10.6 \%)$ \\
\hline np237 & $9.613 E-03$ & $8.677 \mathrm{E}-03$ & $(-9.7 \%)$ \\
\hline $\operatorname{am} 241$ & $1.023 E-03$ & $9.845 \mathrm{E}-04$ & $-3.8 \%)$ \\
\hline $\operatorname{am} 242$ & $2.590 \mathrm{E}-06$ & $1.618 \mathrm{E}-06$ & $(-37.5 \%)$ \\
\hline $\mathrm{cm} 242$ & $1.600 \mathrm{E}-08$ & $1.666 \mathrm{E}-08$ & ( $4.1 \%)$ \\
\hline $\mathrm{cm} 244$ & $1.920 \mathrm{E}-08$ & $8.089 \mathrm{E}-09$ & $(-57.9 \%)$ \\
\hline ru106 & $1.089 \mathrm{E}-04$ & $1.643 \mathrm{E}-04$ & ( $50.9 \%)$ \\
\hline $\operatorname{cs} 134$ & $9.330 \mathrm{E}-05$ & $1.007 \mathrm{E}-04$ & ( $8.0 \%)$ \\
\hline $\operatorname{cs} 137$ & $6.825 \mathrm{E}-02$ & $7.144 \mathrm{E}-02$ & $4.7 \%)$ \\
\hline ce144 & $2.862 \mathrm{E}-04$ & $5.956 \mathrm{E}-04$ & $(108.1 \%)$ \\
\hline nd1 43 & $7.882 \mathrm{E}-02$ & $7.913 \mathrm{E}-02$ & $0.4 \%)$ \\
\hline nd144 & 7. $622 \mathrm{E}-02$ & 7. $613 \mathrm{E}-02$ & $(-0.1 \%)$ \\
\hline nd1 45 & $5.406 \mathrm{E}-02$ & $5.415 \mathrm{E}-02$ & $(0.2 \%)$ \\
\hline nd1 46 & $4.224 \mathrm{E}-02$ & $4.251 \mathrm{E}-02$ & $0.6 \%)$ \\
\hline nd14 8 & $2.419 \mathrm{E}-02$ & $2.426 \mathrm{E}-02$ & $0.3 \%)$ \\
\hline nd15 & 1. $013 \mathrm{E}-02$ & $1.008 \mathrm{E}-02$ & $(-0.5 \%)$ \\
\hline eu154 & $6.250 \mathrm{E}-05$ & $6.127 \mathrm{E}-05$ & $(-2.0 \%)$ \\
\hline
\end{tabular}


japan power demonstration reactor bwr

measured and computed irradiated fuel composition

fuel assembly a-20, rod e2, node 03, $5.602 \mathrm{gwd} / \mathrm{mtu}$

run august 1997

. compares cases using 44GROUPNDF5 library..

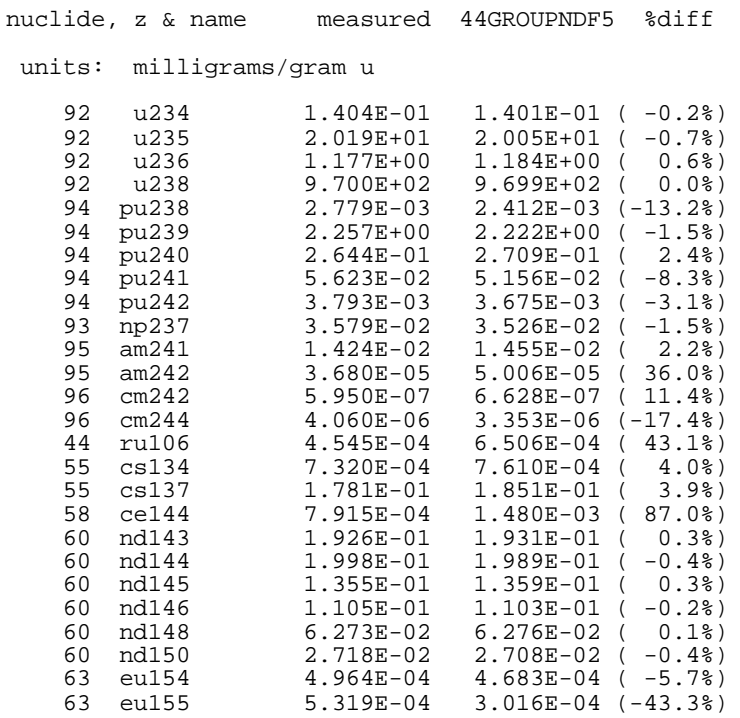

japan power demonstration reactor bwr

measured and computed irradiated fuel composition

fuel assembly a-20, rod e2, node 10, $5.377 \mathrm{gwd} / \mathrm{mtu}$ run august 1997

. compares cases using 44GROUPNDF5 library..

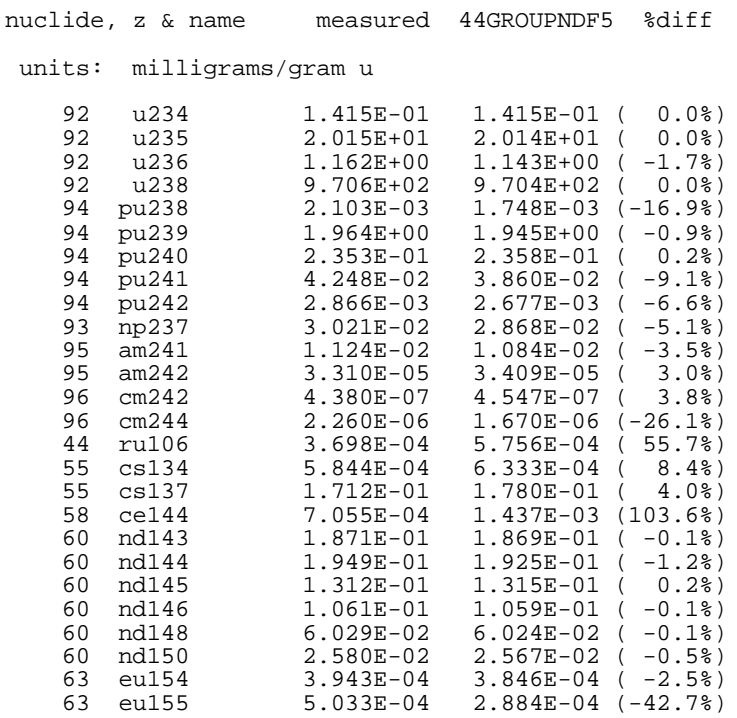




\section{APPENDIX H \\ SENSITIVITY OF CALCULATED CONCENTRATIONS TO ASSUMED MODERATOR DENSITY}

In general, axial moderator densities are not reported as part of the spent fuel operating history associated with chemical assay data. Therefore, it is incumbent upon the modeler to estimate moderator densities. Experience with spent fuel modeling suggests that detailed time-varying models are not necessary; however, it is important to obtain a good estimate of the time-averaged moderator density at an axial location to best calculate spent fuel compositions.

One of the largest uncertainties in the current sets of models for the Cooper and Gundremmingen BWRs is the moderator density. This factor was not a problem for JPDR, because moderator densities were specified in published data describing the experiment. In this work, coarse estimates of moderator densities in the Cooper and Gundremmingen models were obtained using a simplistic conservation model. Comparison of results between Cooper and Gundremmingen relative to JPDR shows that, in general, isotopic concentrations are better for JPDR relative to the other two reactor fuels. Note, however, that JPDR fuel possesses low burnup relative to the other fuel samples, and would therefore also be expected to have less calculated/measured error than the other fuel samples. Nevertheless, it was felt necessary to try to assess the potential error in spent fuel predictions for Cooper and Gundremmingen due to uncertainties in time-averaged moderator densities.

Calculations were performed for four selected cases, taking a high nominal moderator density case (located axially low in the fuel rod) and low moderator density case (located axially high in the fuel rod), for each of the two reactors. The magnitude of the nominal density for each was varied by $\pm 20 \%$, and the depletion calculations were rerun for each new density. A value of $20 \%$ was assumed as this was felt to bound the uncertainty in derived moderator densities. Tables H.1 through H.4 list the calculated concentrations for each of the most important spent fuel nuclides. The table lists the nuclide concentrations for nominal moderator density (as used in the primary analyses described in the body of this report) and for each perturbed density. After each perturbed-density concentration, the error relative to the nominal density case is shown. Similarly, Tables H-5 through H-8 list the calculated-to-measured ratios for the same conditions. In these tables, isotopic concentrations computed for the nominal and adjusted moderator densities are 
compared with measured data. Percentage differences illustrate the differences between calculated concentrations and measured data for each perturbation. These comparisons illustrate the potential magnitude of isotopic variations as a function of variable.

Based on the results presented in these tables, the following observations are made:

- Sensitivity to moderator density appears to be close to linear for most nuclides (i.e., given a $\Delta \mathrm{x}$ change in nuclide concentration for a $20 \%$ moderator density increase); for a $20 \%$ decrease in moderator density, an approximate nuclide concentration change of $-\Delta \mathrm{x}$ is observed.

- The actinides most sensitive to density changes are ${ }^{235} \mathrm{U},{ }^{238} \mathrm{Pu},{ }^{239} \mathrm{Pu},{ }^{241} \mathrm{Pu}$ and ${ }^{241} \mathrm{Am} .{ }^{241} \mathrm{Am}$ sensitivity closely follows that of ${ }^{241} \mathrm{Pu}$, since the former is produced largely by the decay of the latter.

- Decreased density results in increased quantities of the above actinides, and vice versa. Decreased density results in spectral hardening, which in turn results in greater Pu production from ${ }^{238} \mathrm{U}$ neutron capture, and decreased ${ }^{235} \mathrm{U}$ depletion due to increased $\mathrm{Pu}$ fission.

- Of the fission products, only ${ }^{149} \mathrm{Sm},{ }^{151} \mathrm{Sm}$, and, to a lesser extent, ${ }^{135} \mathrm{Cs}$, are sensitive to density changes; all three increase with decreasing moderator density. The two Sm nuclides are produced more rapidly by $\mathrm{Pu}$ fission than $\mathrm{U}$ fission, and therefore are expected to increase in concentration with spectral hardening.

- No definite conclusions can be drawn as to the appropriateness of the assumed (nominal) moderator densities for these cases. The tables show that for some nuclides the lower density improves agreement with the experiment; for other nuclides, the same is true for the higher-density calculation. For the remainder of the nuclides, the nominal density calculations result in the best agreement with measured data. 


\section{Table H.1. Sensitivity of predicted concentrations to moderator density for}

a low-average-density Cooper fuel sample

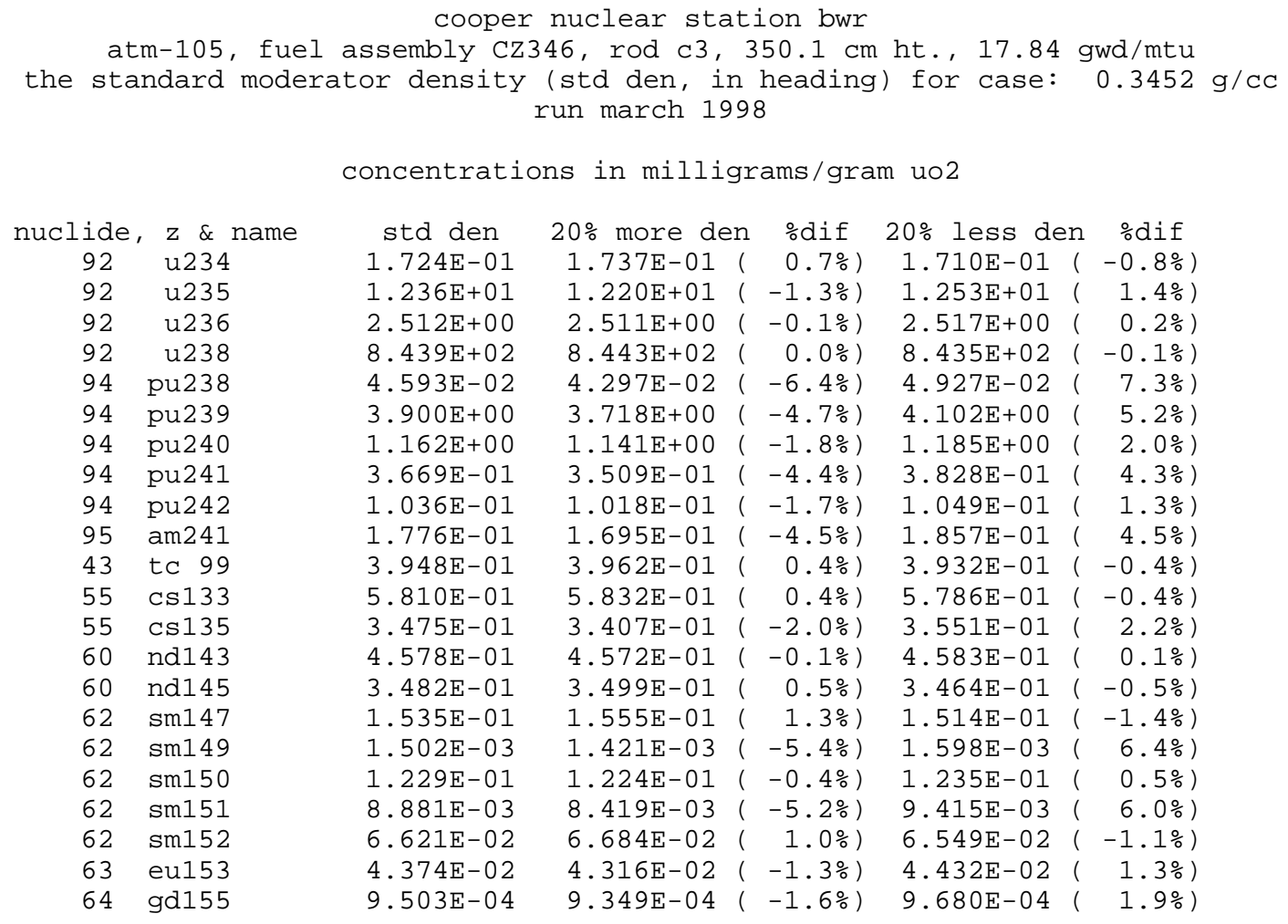




\section{Table H.2. Sensitivity of predicted concentrations to moderator density for a high-average-density Cooper fuel sample}

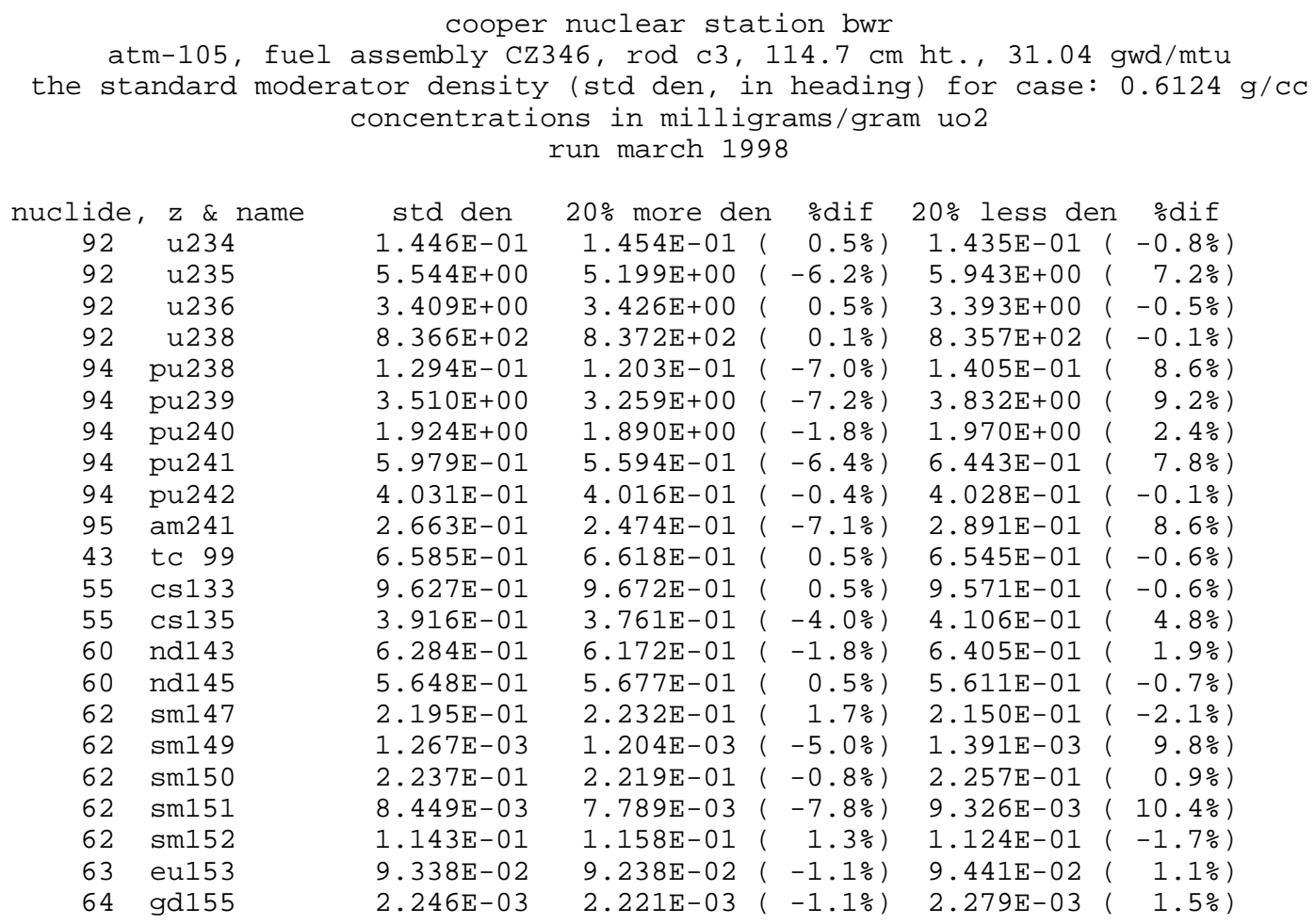




\section{Table H.3. Sensitivity of predicted concentrations to moderator density for a low-average-density Gundremmingen fuel sample}

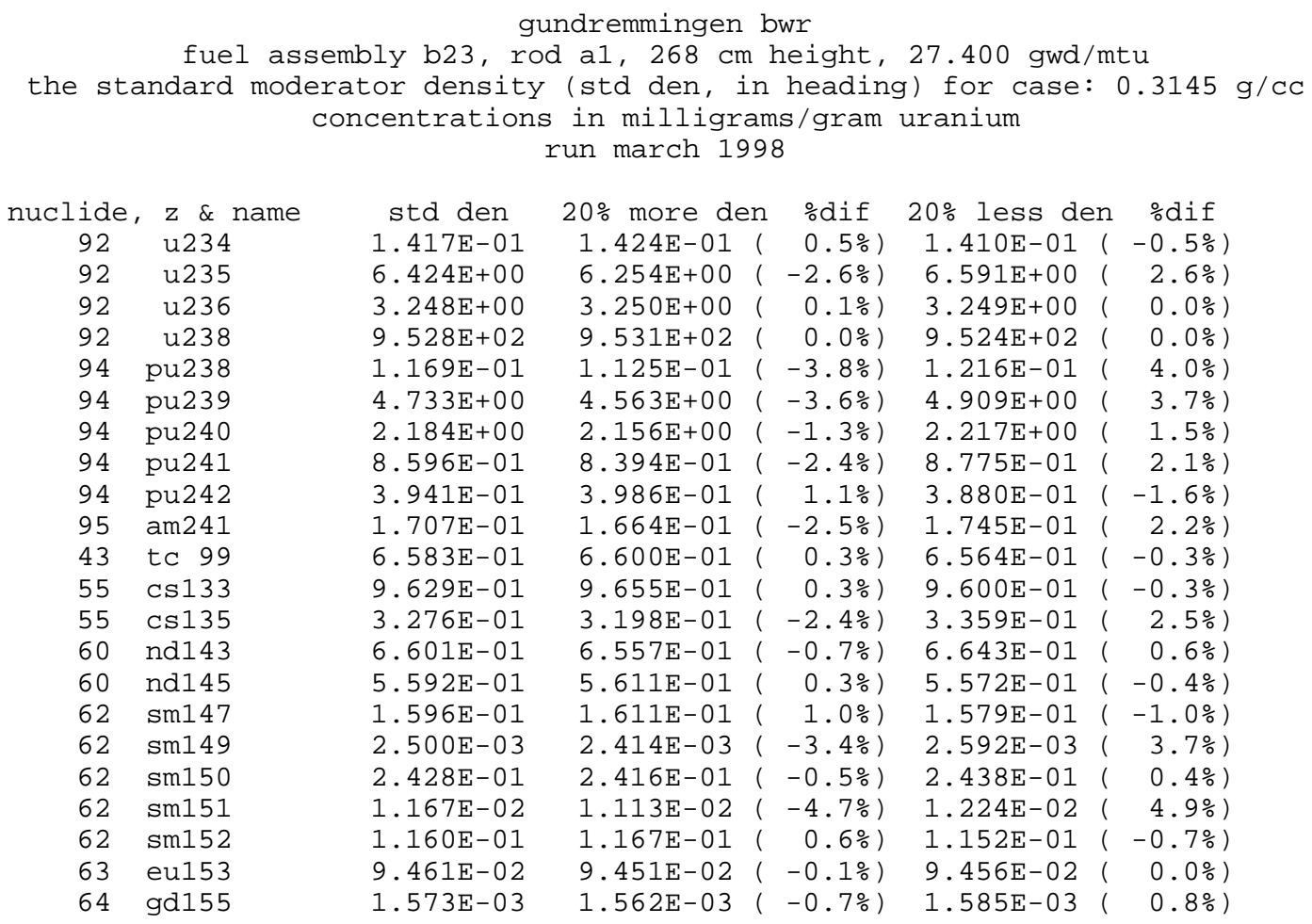




\section{Table H.4. Sensitivity of predicted concentrations to moderator density for a high-average-density Gundremmingen fuel sample}

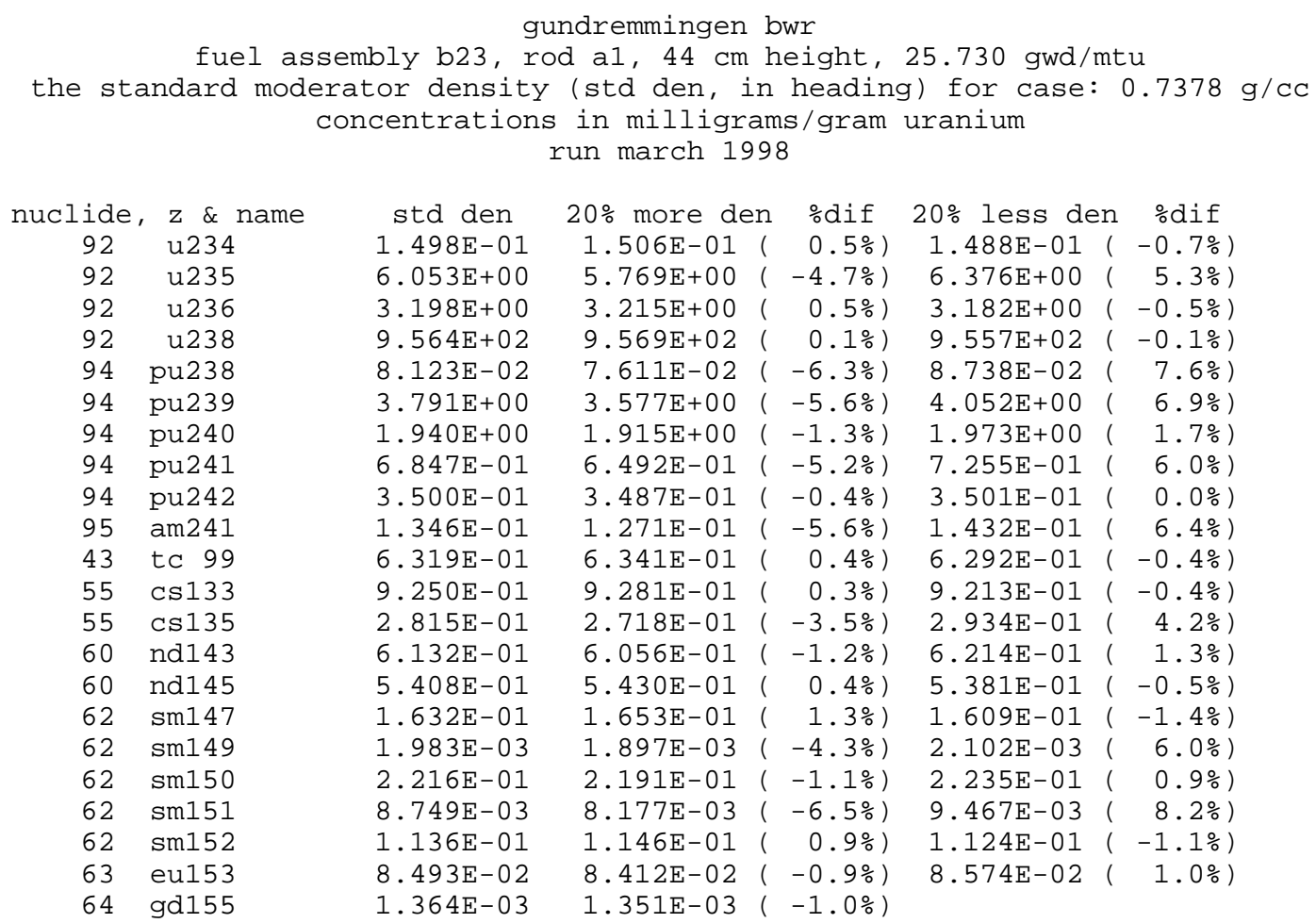




\section{Table H.5. Sensitivity of predicted-to-measured ratios to moderator density for a low-average-density Cooper fuel sample}

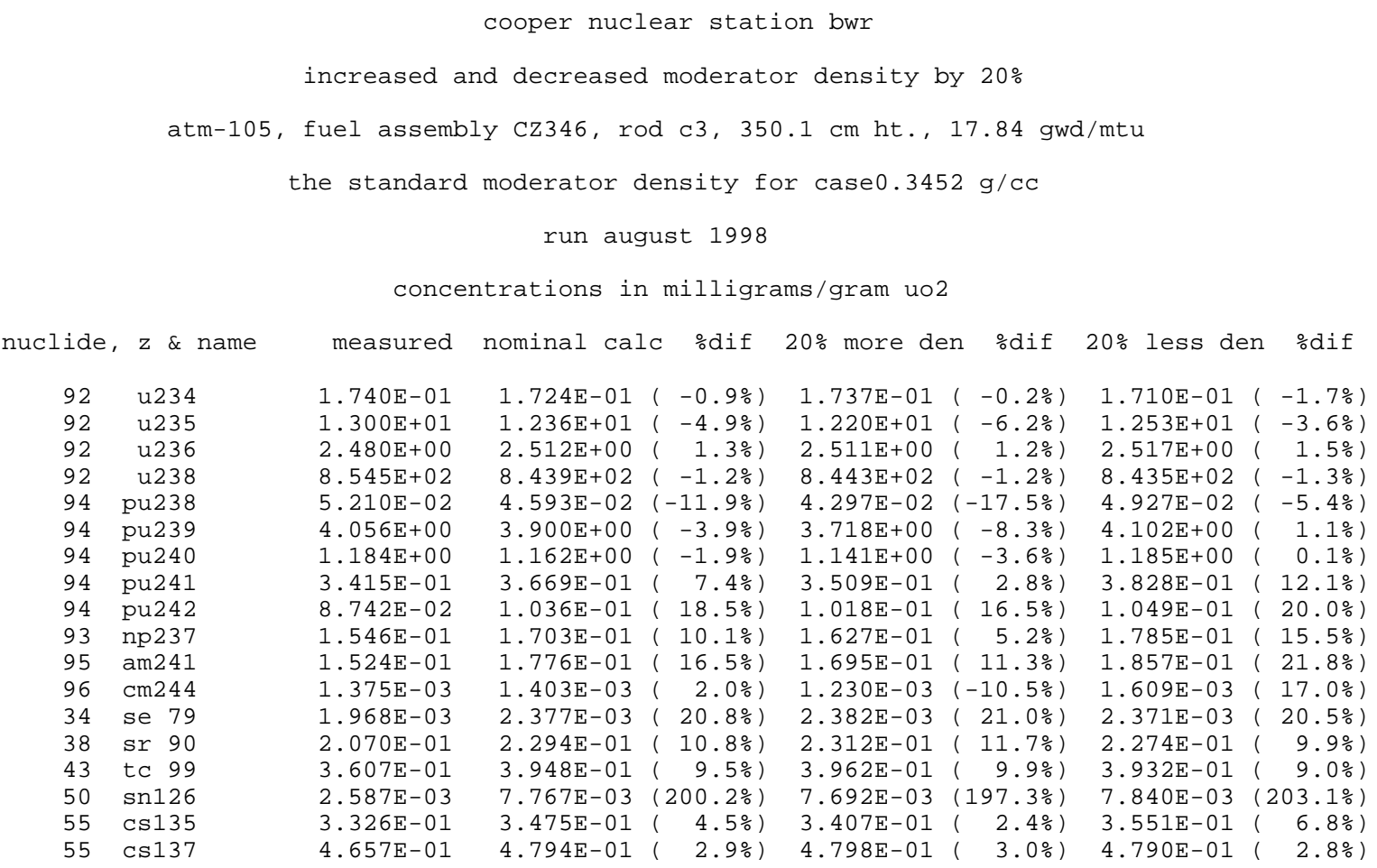




\section{Table H.6. Sensitivity of predicted-to-measured ratios to moderator density for a high-average-density Cooper fuel sample}

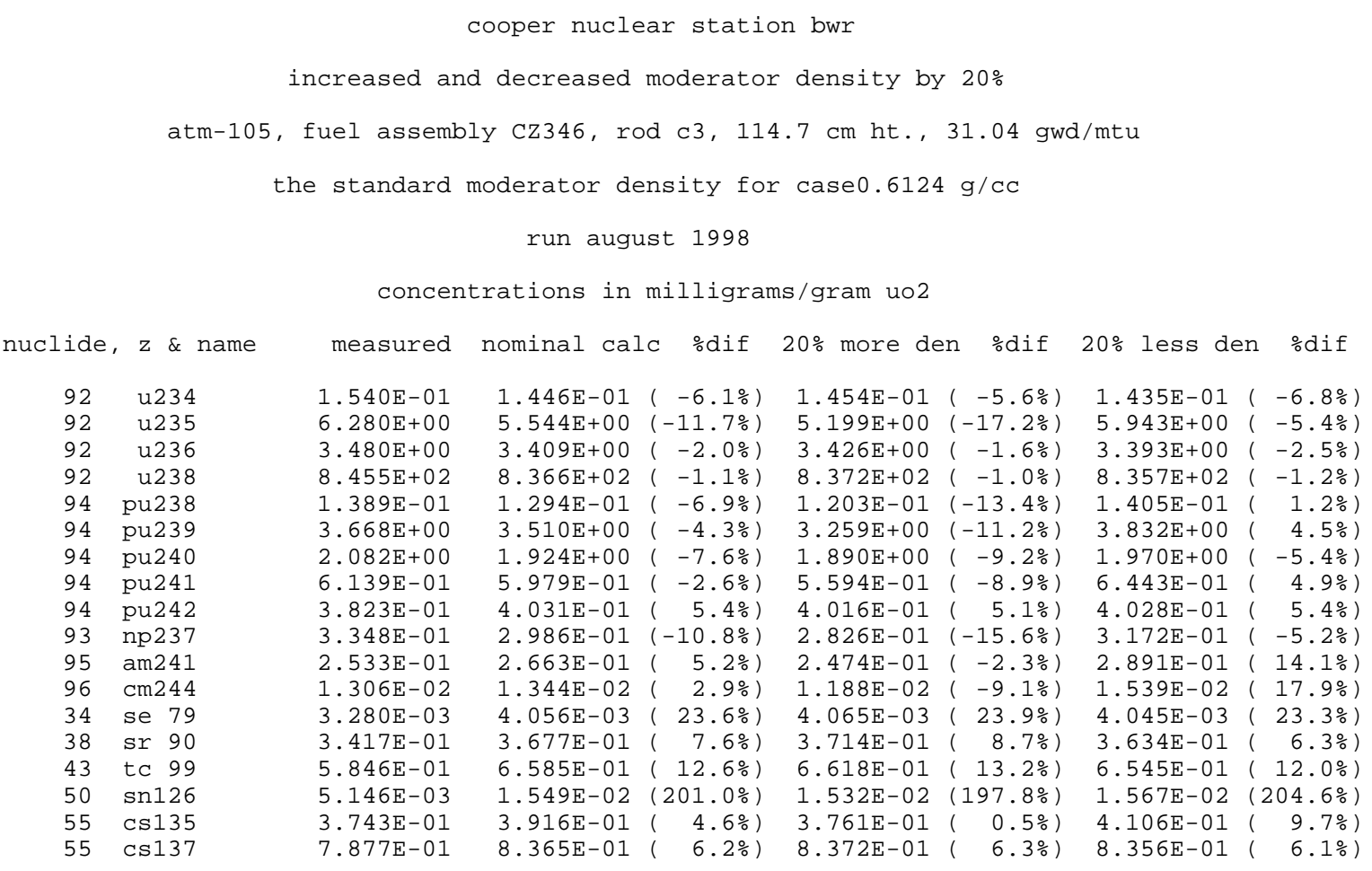




\section{Table H.7. Sensitivity of predicted-to-measured ratios to moderator density for a low-average-density Gundremmingen fuel sample}

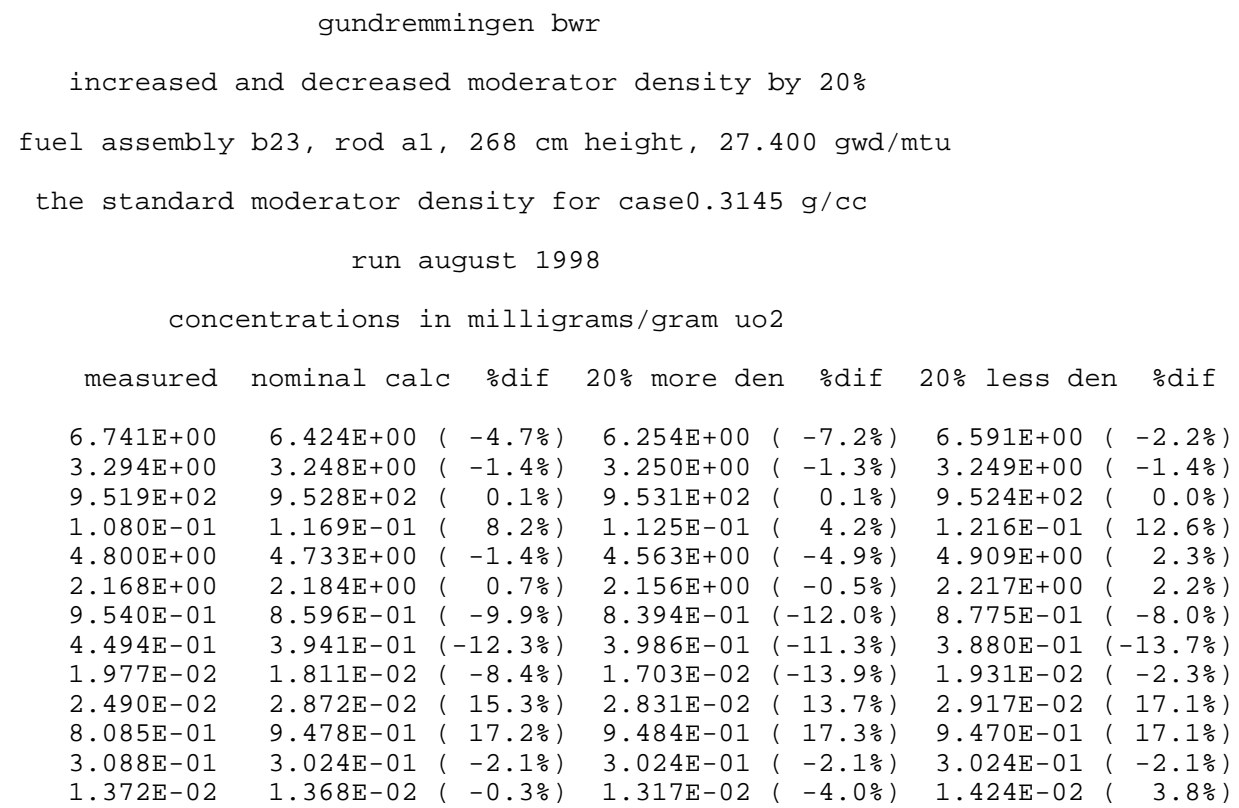




\section{Table H.8. Sensitivity of predicted-to-measured ratios to moderator density for a high-average-density Gundremmingen fuel sample}

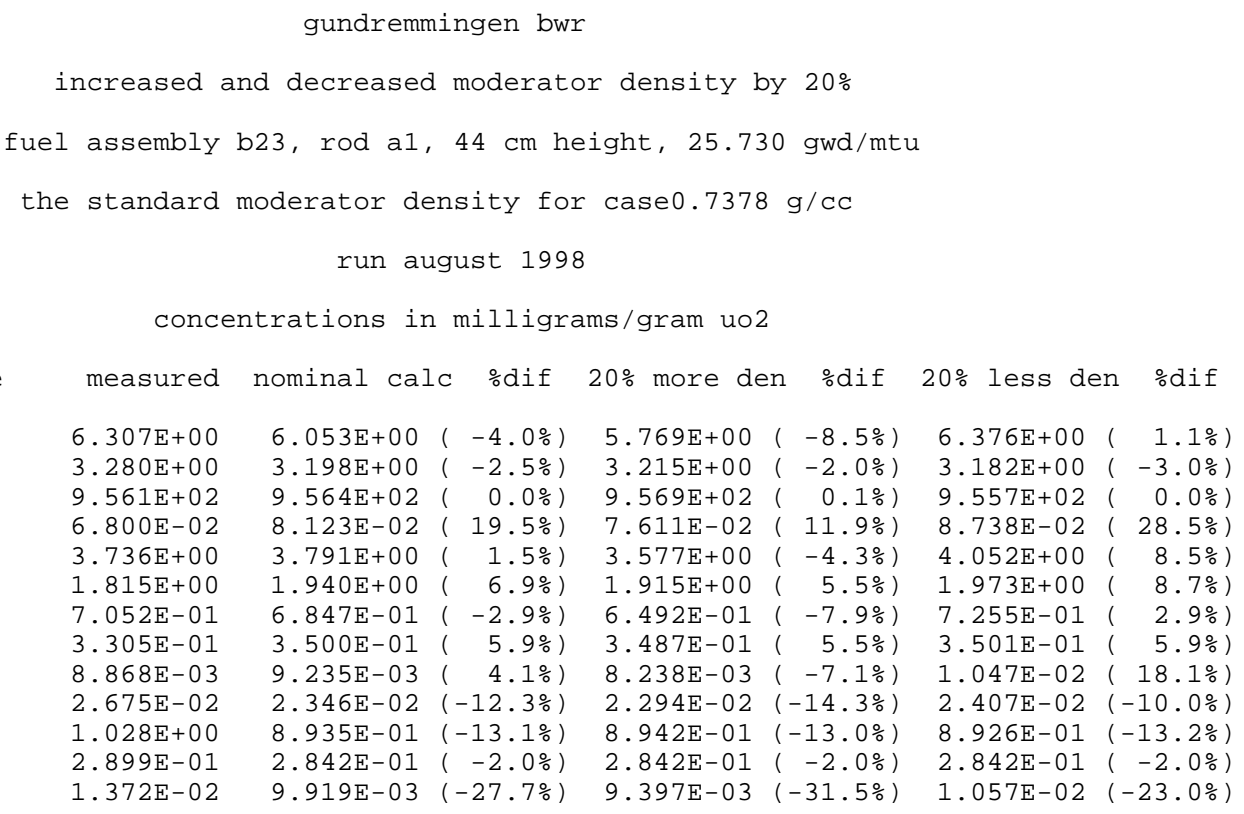


ORNL/TM-13315

\section{INTERNAL DISTRIBUTION}

1. C. W. Alexander

2. S. M. Bowman

3. B. L. Broadhead

4. J. A. Bucholz

5-9. W. C. Carter

10. R. D. Dabbs

11-15. M. D. DeHart

16. M. B. Emmett

17-21. O. W. Hermann

22. M. A. Kuliasha

23. L. C. Leal

24. S. B. Ludwig

25. S. K. Martin

26. G. E. Michaels

27. B. D. Murphy

28. J. V. Pace

29-33. C. V. Parks
34. L. M. Petrie

35. R. T. Primm

36. J.-P. Renier

37. J. W. Roddy

38. R. W. Roussin

39. J. C. Ryman

40. C. H. Shappert

41. C. O. Slater

42-44. R. M. Westfall

45. B. A. Worley

46. R. Q. Wright

47. Laboratory Records-RC

48. Central Research Library

\section{EXTERNAL DISTRIBUTION}

49. M. L. Anderson, Framatome Cogema Fuels, 1261 Town Center Drive, Las Vegas, Nevada 89134

50. M. G. Bailey, Office of Nuclear Material Safety \& Safeguards, U.S. Nuclear Regulatory Commission, MS O6 G22, Washington, DC 20555

51. L. Barrett, Office of Civilian Radioactive Waste Management, RW-232 20545, U.S. Department of Energy, Washington, DC 20545

52. C. J. Benson, Bettis Atomic Power Laboratory, P.O. Box 79, West Mifflin, PA 15122

53. R. J. Cacciapouti, Yankee Atomic Electric Co., 1617 Worcester Rd., Framington, MA 01701

54. D. E. Carlson, U.S. Nuclear Regulatory Commission, Spent Fuel Project Office, MS O6 G22, Washington, DC 20555

55. J. Clark, 2650 Park Tower Drive, Suite 800, Vienna, VA 22180

56. J. Conde, Consejo de Seguridad Nuclear, Justo Dorado, 11, 28040 Madrid, Spain

57. D. R. Conners, Bettis Atomic Power Laboratory, P.O. Box 79, West Mifflin, PA 15122

58. W. Davis, Framatome Cogema Fuels, 1261 Town Center Drive, Las Vegas, Nevada 89134

59. T. W. Doering, Framatome Cogema Fuels, 1261 Town Center Drive, Las Vegas, Nevada 89134 
60. I. Gauld, Whiteshell Laboratories, AECL Research, Pinawa Manitoba R0E1L0 Canada

61. G. Gualdrini, ENEA-TIB/FICS, C.R.E. "E. Clementel," Via Mazzini, 2, I-40139 Bologna, Italy

62. H. Geiser, Wissenschaftlich-Technische Ingenieurberatung GmbH, P.O. Box 13 40, 52410 Julich, Federal Republic of Germany

63. S. Hanauer, U.S. Department of Energy, RW-22, Washington, DC 20545

64. C. J. Haughney, U.S. Nuclear Regulatory Commission, Spent Fuel Project Office, OWFN 6 F18, Washington, DC 20555

65. L. Hassler, Babcock \& Wilcox, P.O. Box 10935, Lynchburg, VA 24506-0935

66. D. Henderson, Framatome Cogema, 1261 Town Center Drive, Las Vegas, Nevada 89134

67. U. Jenquin, Battelle Pacific Northwest Laboratory, P.O. Box 999, Richland, WA 99352

68. E. Johnson, E. R. Johnson Associates, Inc., 9302 Lee Hwy, Suite 200, Fairfax, VA 22031

69. G. Kirchner, University of Bremen, FB 1 Postfach 330440, D-W-2800 Bremen 33, Federal Republic of Germany

70. C. Kouts, Office of Civilian Radioactive Waste Management, RW-36, U.S. Department of Energy, Washington, DC 20545

71. W. H. Lake, Office of Civilian Radioactive Waste Management, U.S. Department of Energy, RW-46, Washington, DC 20585

72. R. Lambert, Electric Power Research Institute, 3412 Hillview Ave., Palo Alto, CA 94304

73. D. Lancaster, 2650 Park Tower Drive, Suite 800, Vienna, VA 22180

74. D. Langstaff, U.S. Department of Energy, Richland Operations Office, P.O. Box 550, Richland, WA 99352

75. Y. L. Liu, Argonne National Laboratory, 9700 S. Cass Ave., Bldg.308, Argonne, IL 60439-4825

76. M. Mason, Transnuclear, Two Skyline Drive, Hawthorne, NY 10532-2120

77. M. Mount, Lawrence Livermore National Laboratory, P.O. Box 808, Livermore, CA 94550

78. P. K. Nair, Manager, Engineered Barrier System, Center for Nuclear Waste Regulatory Analyses, Southwest Research Institute, 6220 Culebra Road, San Antonio, TX 782385166

79. D. Napolitano, Nuclear Assurance Corp., 5720 Peachtree Parkway, Norcross, GA 30092

80. K. A. Neimer, Duke Engineering \& Services, 230 S. Tyron St., P.O. Box 1004, Charlotte, NC 28201-1004

81. C. W. Nilsen, Office of Nuclear Material Safety and Safeguards, U.S. Nuclear Regulatory Commission, MS T9 F31, Washington, DC 20555

82-83. Office of Scientific and Technical Information, U.S. Department of Energy, P.O. Box 62, Oak Ridge, TN 37831

84. Office of the Assistant Manager for Energy Research and Development, Department of Energy Oak Ridge Operations (DOE-ORO), P.O. Box 2008, Oak Ridge, TN 37831

85. N. L. Osgood, U.S. Nuclear Regulatory Commission, Office of Nuclear Materials Safety and Safeguards, MS O6 F18, Washington, DC 20555

86. O. Ozer, Electric Power Research Institute, 3412 Hillview Ave., Palo Alto, CA 94304

86. T. Parish, Department of Nuclear Engineering, Texas A \& M University, College Station, TX 77843-3313 
88. B. Reid, Battelle Pacific Northwest Laboratory, P.O. Box 999, Richland, WA 99352

89. C. Rombough, CTR Technical Services, Inc., 5619 Misty Crest Dr., Arlington, TX 76017-4147

90. M. Smith, U.S. Department of Energy, Yucca Mountain Project Office, 101 Convention Center Dr., Las Vegas, NV 89190

91. M. Smith, Virginia Power Co., P.O. Box 2666, Richmond, VA 23261

92. F. C. Sturz, Office of Nuclear Material Safety \& Safeguards, U.S. Nuclear Regulatory Commission, MS O6 G22, Washington, DC 20555

93. T. Suto, Power Reactor and Nuclear Fuel Development Corp., 1-9-13, Akasaka, Minato$\mathrm{Ku}$, Tokyo, Japan

94. R. J. Talbert, Battelle Pacific Northwest Laboratory, P.O. Box 999, Richland, WA 99352

95. H. Taniuchi, Kobe Steel, Ltd., 2-3-1 Shinhama, Arai-Cho, Takasago, 676 Japan

96. D. A. Thomas, Framatome Cogema, 1261 Town Center Drive, Las Vegas, Nevada 89134

97. J. R. Thornton, Duke Engineering \& Services, 230 S. Tyron St., P.O. Box 1004, Charlotte, NC 28201-1004

98. J. Vujic, Department of Nuclear Engineering, University of California at Berkeley, Berkeley, CA 94720

99. G. Walden, Duke Power Co., P.O. Box 33189, Charlotte, NC 28242

100. M. E. Wangler, U.S. Department of Energy, EH-33.2, Washington, DC 20585-0002

101. R. M. Weller, U.S. Nuclear Regulatory Commission, MS T7 C6, Washington, DC 20555

102. A. Wells, 2846 Peachtree Walk, Duluth, GA 30136

103. W. Weyer, Wissenschaftlich-Technische Ingenieurberatung GMBH, Mozartstrasse 13, 5177 Titz-Rodingen, Federal Republic of Germany

104. B. H. White, U.S. Nuclear Regulatory Commission, Spent Fuel Project Office, MS O6 F18, Washington, DC 20555

105. J. Williams, Office of Civilian Radioactive Waste Management, U.S. Department of Energy, RW-46, Washington, DC 20545

106. M. L. Williams, LSU Nuclear Science Center, Baton Rouge, LA 70803

107. C. J. Withee, U.S. Nuclear Regulatory Commission, Spent Fuel Project Office, MS O6 G22, Washington, DC 20555

108. R. Yang, Electric Power Research Institute, 3412 Hillview Ave., Palo Alto, CA 94304 
